\title{
The
}

\section{Central American Species of Quercus}

By CORNELIUS H. MULLER

U. S. DEPARTMENT OF AGRICULTURE

Miscerlaneous Poblticitiog No. 477 

Historic, archived document

Do not assume content reflects current scientific knowledge, policies, or practices. 


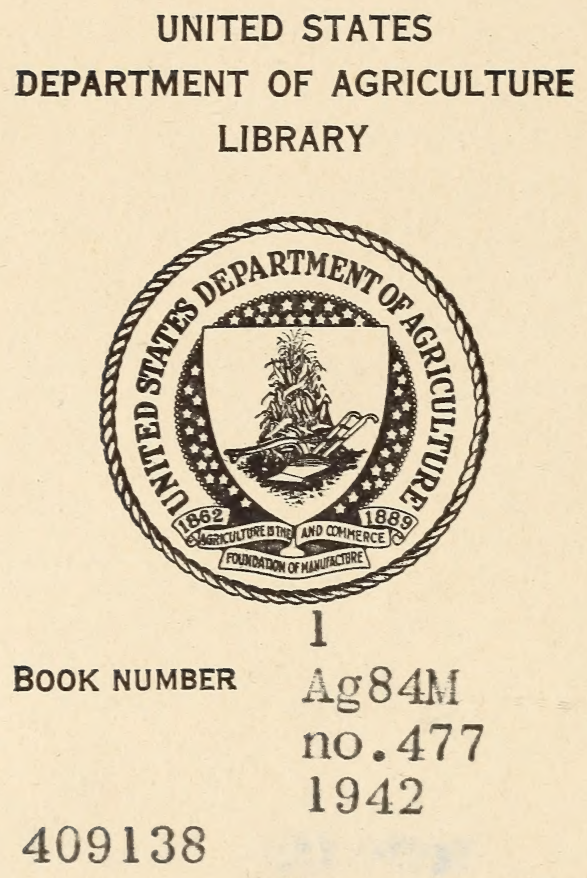



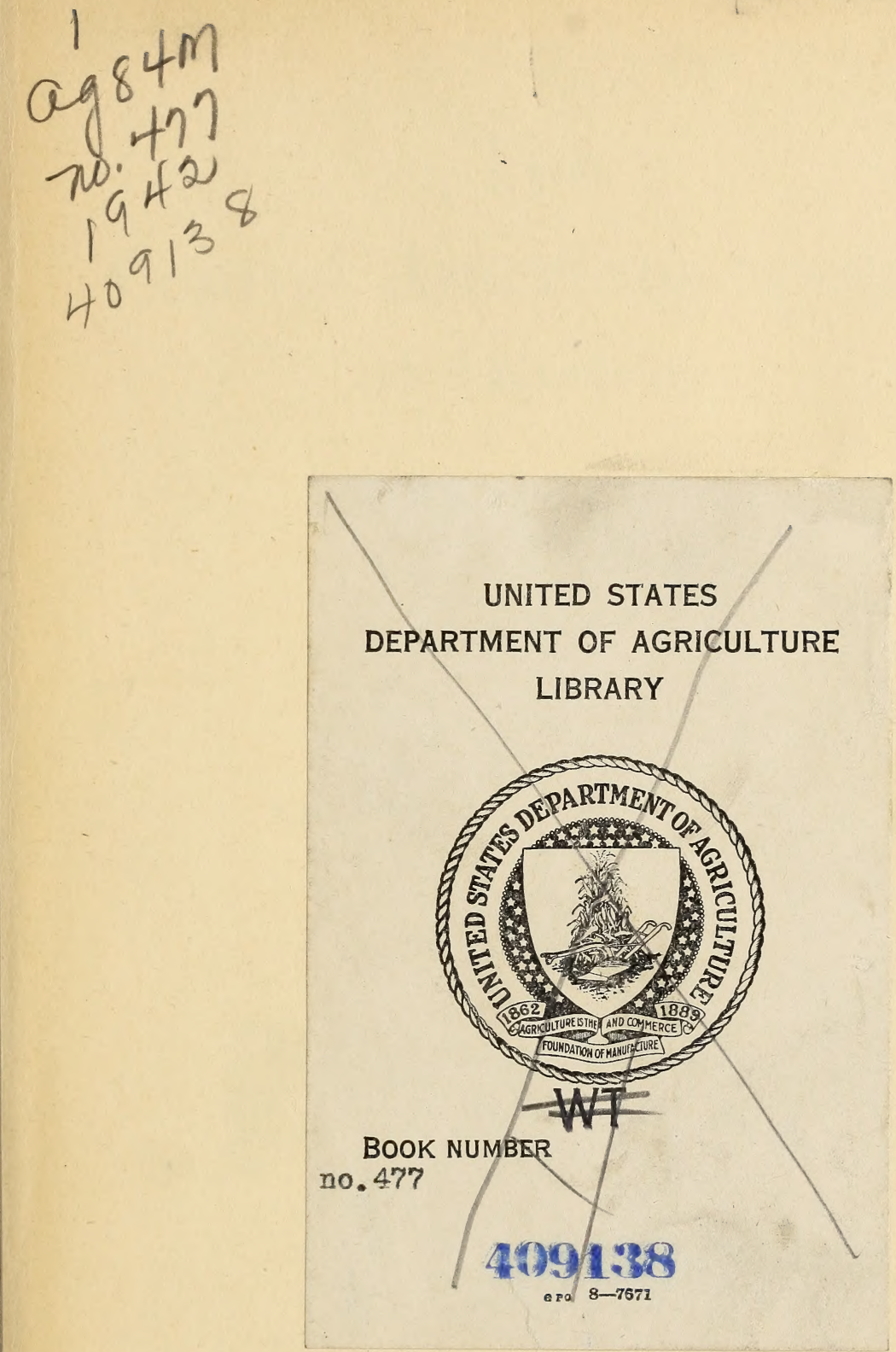



\title{
The \\ Central American Species of Quercus
}

\author{
By CORNELIUS H. MULLER \\ Assistant Botanist
}

Division of Plant Exploration and Introduction

Bureau of Plant Industry

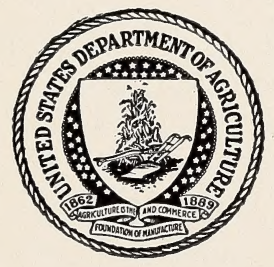

MISCELLANEOUS PUBLICATION No. 477

UNITED STATES DEPARTMENT OF AGRICULTURE ISSUED JULY 1942

UNITED STATES GOVERNMENT PRINTING OFFICE, WASHINGTON, 1942 For sale by the Superintendent of Documents, Washington, D. C. - . - - Price $\$ 1.00$ (Buckram) 



\section{O N T E N T S}

Introduction . . . . . . . . . . . . . . . 1

Subgeneric concepts . . . . . . . . . . . 2

Species concept . . . . . . . . . . . . . . . 4

Comparative knowledge of areas . . . . . . . . 6

Morphological basis of classification . . . . . . . . 6

Methods . . . . . . . . . . . . 12

Systematic treatment. . . . . . . . . . . . . 13

Excluded species . . . . . . . . . . . . . . 82

List of exsiccatae . . . . . . . . . . . . . 82

Literature cited . . . . . . . . . . . 90

Index. . . . . . . . . . . . . . . . 91 



\section{The Central American Species of Quercus}

\section{INTRODUCTION}

The first complete review of the Central American oaks appeared in A. de Candolle's treatment of the entire genus, as then known, in 1864 (1). ${ }^{1} \quad$ This very full descriptive compilation lacks both keys and illustrations. In 1869 Oersted treated these species, together with the more northerly ones, in a sumptuously illustrated tome based upon the work of the then deceased Liebmann (2). No more recent work on the subject can compare with the beauty and usefulness of this luxurious volume, and it is not likely that so ambitious a publication will soon again be issued. Much less significant is a treatment of the American species in 1884 by Wenzig ( 7$)$. The last complete treatment of the species of Central America appeared in Trelease's monumental treatise (6) on the American oaks in $1924 .{ }^{2}$ This work includes illustrations of the types of most of the species as well as of representative variations of nearly all species.

It has been found necessary to reduce many of the species erected by Trelease in his monograph and by various authors subsequently. Most of the species that have been placed in synonymy seem to have been described from too little material to serve as a basis for specific distinction. Subsequent collections, and even mere comparison of the types with an abundance of earlier collections, have clearly indicated the necessity of numerous reductions. The lack of any suitable disposition of these indistinct species has motivated the present treatment.

It must be emphasized, however, that these reductions to synonymy do not constitute an unfavorable commentary upon the usefulness of Trelease's monograph. The mere fact that his species concept admitted entities too fine to avoid confusing the casual user of his work in no way reflects upon his accuracy in analyzing the phylogenetic situation. In many instances the erection of several too closely related species, each adequately illustrated, has presented a clear picture of the intraspecific variation of the whole.

Recent explorations incidental to the floristic studies of Standley and Steyermark in Guatemala and of Woodson and Seibert in Panama have added tremendously to the data that need incorporation into the knowledge of Central American oaks. It was the task of preparing treatments of the Guatemala and Panama species to be included in these floras that most emphatically indicated the need of a review of

\footnotetext{
Italic numbers in parentheses refer to Literature Cited, p. 90.

2 The date of this work was erroneously given in the Gray Herbarium card index as 1925 . Consultation of the records of the National Academy of Sciences revealed that the Academy received the publication from the printer on November 5, 1924, and immediately placed several copies in the mail. Prior to January 1 , 1925,210 copies had been distributed. The date of publication is therefore correctly given on the title page as 1924 .
} 
the entire Central American oak flora. This same problem has necessitated an extension of the area defined as Central America to include the Mexican states below the Isthmus of Tehuantepec and the Colombian Andes in South America.

Specimens have been borrowed from the following herbaria: ${ }^{3}$

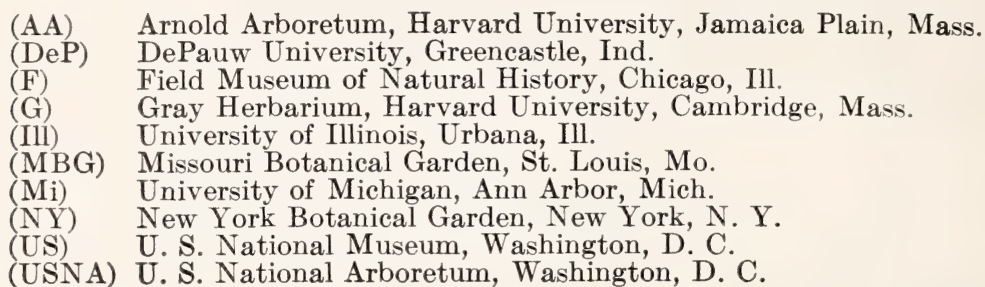

The author wishes to make grateful acknowledgment of his indebtedness to the custodians of these herbaria for their courtesies in permitting the study of their oak material over an extensive period of time. He feels particularly indebted to Paul C. Standley of the Field Museum and Robert E. Woodson of the Missouri Botanical Garden whose numerous favors greatly facilitated the completion of the work. S. F. Blake of the Bureau of Plant Industry rendered valuable aid and criticism, particularly with the Latin diagnoses.

\section{SUBGENERIC CONCEPTS}

The subgenera outlined by Trelease seem in no need of revision, but the arrangement of species within them may be improved in the light of recent studies. The treatment of the subgenera as genera by Schwarz $(4,5)$ seems to have been done without sufficient reason or advantage.

Only two subgenera occur in Central America. They are Lepidobalanus (in place of which Trelease applied Engelmann's synonymous name, Leucobalanus) and Erythrobalanus. Lepidobalanus includes the European Quercus robur L., the type species of the genus. Oersted's subgenus Macrobalanus, which Schwarz has raised to generic rank, also belongs here. It differs from Lepidobalanus only in having unequal cotyledons (and consequently lateral and obliquely directed radicles) and in no sense constitutes a group that one could term generically distinct from Quercus, subgenus Lepidobalanus.

There might be a more convincing argument for the generic distinction of Erythrobalanus, for it is distinguished from Lepidobalanus by leaf, flower, cup, and acorn characters, which seem rather important. However, it is quite clear that Schwarz proposed its generic distinction without first familiarizing himself with all the species, for his first publication on the subject referred the Colombian oaks to Lepidobalanus. The following year he concluded that they belonged in Erythrobalanus. Also in his first publication he referred the series Durifoliae, Scytophyllae, Costaricenses, Citrifoliae, and Borucasanae to Lepidobalanus. These series are composed of species that, for the most part, are very definitely members of Erythrobalanus. He seems to have placed them in Lepidobalanus solely upon the basis of their lateral abortive ovules and without regard for the several other more

3 The letters in parentheses are used in the citation of specimens and the explanations of the illustrations to indicate the herbaria from which material has been available for study. 
constant, and hence more significant, characters. There are some species in north and central Mexico (notably Q. chrysophylla Humboldt and Bonpland) that are difficult to refer conclusively to one or the other of the groups.

Erythrobalanus is distinguished from Lepidobalanus by having its leaves aristate-tipped (when toothed), its anthers usually only six, the stigmas elongate and gradually dilated, cup scales thin, acorn shell tomentose within, and abortive ovules apical. This imposing array of differences would certainly deserve generic distinction if they were constant. However, certain species of Lepidobalanus (e. g., Q. turbinella Greene) and the American species of the subgenus Protobalanus have teeth on their leaves clearly intermediate between the aristae of Erythrobalanus and the merely mucronate tips of Lepidobalanus. The gradually dilated and abruptly dilated style types occasionally merge into one another as do also the stamen numbers. The cup scales of some species of both groups are slightly thickened and not clearly representative of either. The acorn shell of Protobalanus is as tomentose as that of Erythrobalanus. The abortive ovules of many species of Erythrobalanus are deeply lateral or even basal on occasion.

These differences usually hold true in a great preponderance of species, but they may scarcely be depended upon. Apparently only the tomentose acorn shell of Erythrobalanus (which it shares with Protobalanus) is constant. The other characters are being revealed to be less and less dependable as more fruiting material becomes available. It seems, therefore, that the sum total of differences may best be regarded as a rather poor subgeneric distinction. In no sense is the difference to be regarded as generic. However, it must not be concluded that there exists too little difference between the groups to warrant subgeneric rank. For a more detailed discussion of this question see Muller (3).

Williams (8) studied the wood anatomy of several species of American oaks and reaffirmed a distinction between the subgenera described by several earlier workers. He found eight species that had at one time or another been considered members of Lepidobalanus but that had Erythrobalanus wood. He proposed to delimit the subgenera on this line. Tillson and Muller ${ }^{4}$ found that the so-called Erythrobalanus wood type ranges widely in Lepidobalanus and is scarcely correlated with any other character. It is to be concluded from their evidence that the wood type may serve as an indication of phylogenetic relationship of the species within Lepidobalanus rather than as the basis of a realignment of Lepidobalanus and Erythrobalanus.

The series of species brought together in named groups by Trelease are for the most part too finely divided for practicability. In a few instances all the species of a single series have been reduced to synonymy under one of their number. His numerous series containing single species seem to serve no purpose, and these have been grouped together whenever that proved possible. A great deal of grouping may still be done with profit, but this must await a study of the central Mexican species. These series are partly natural and partly artificial. Most of those in which he placed several species, e. g., the Virentes, the Acutifoliae, and the Reticulatae, are quite natural. The ones to

\footnotetext{
4 Tillson, Albert H., and Muller, C. H. ANatomical and taxonomic approaches to subgeneric SEGREGATION IN AMERICAN QUERCUS. Unpublished manuscript in the files of the Division of Plant Exploration and Introduction.
} 
which he referred a single species are in most cases scarcely to be held separate from some neighboring series. The series Cyclobalanoideae, for instance, is not only synonymous with the Corrugatae, but its one species, Quercus cyclobalanoides, is synonymous with Q. corrugata.

In a consideration of the Central American species alone, no suitable line has been discorered along which the species could be divided into sections intermediate in rank between the subgenera and the series.

It is apparent that the morphological basis of the classification of Quercus offers too little evidence of the best lines along which the many species may be segregated into greater groups. The distinction between the typical subgenus Lepidobalanus and the subgenus Erythrobalanus is not wholly satisfactory. That between the various series, even though a real effort has been made to include in them natural groups, is even less so.

\section{SPECIES CONCEPT}

To discuss one's species concept without defining "species" perhaps seems a bit negligent. Considering the facts that very few taxonomists agree on the definition of the term and that the phenomenon (if it is a real one) varies so much from genus to genus as to necessitate drastic changes in concept from group to group, it seems useless to attempt more than a statement of position in general terms.

Species in Quercus seldom exhibit the same degree of distinctness from one another. For instance, Q. aáata is not closely related to any other known species, and Q. tristis is only doubtfully distinct from Q. castanea. There is therefore no sharp line (or no line at all) on one side of which the degree of distinctness constitutes varietal rank and on the other specific rank. It is with misgivings that the varietal category is used in this treatment at all. Only the basis of the forma, which is not employed in this publication, can be clearly stated, and that merely because it embodies a phenotype of simple genetic differences.

Even within a single genus it is sometimes necessary to admit more than one concept in defining species. This is especially true in Quercus, which contains widely ranging, ecologically tolerant species and often closely related ecologically intolerant species of restricted range. In either case the species must be defined so as to allow for the maximum of rariation compatible with a sense of order. In the Atlantic region of the United States occur several species of the first class that, because of their wide ranges and consequent minor differentiations, have been described repeatedly with no better result than the multiplication of synonyms. In the United States-Mexican border region, on the other hand, there exists a condition induced by the mountainous terrain and characteristic basin and range topography that has favored a relatively high percentage of endemics. In some cases quite distinct species are known that exhibit less profound differences than the variation often encountered within a single species of the Atlantic United States. Of the border region species, the more xeric are usually the more widespread, since the less xeric types (which are often endemics) are confined to the relatively scarce moist, or at least mesic, habitats. 
In Central America both types of distribution are noted. In wide areas of similar and closely associated or contiguous habitats, as, for instance, the less rugged eastern watershed, very widespread species are encountered. These are for the most part species of tropical rain forests, especially toward the upper limits of the tropical zone. Quercus insignis and $Q$. oleoides are examples that range variously from Tamaulipas and Veracruz in Mexico to Honduras and Costa Rica. The more rugged western watershed bears some widespread species and some rather restricted ones. The extremely high peaks, on the other hand, yield a number of endemics such as Q. costaricensis, Q. irazuensis, and Q. pacayana. Although it is obvious that the basic cause of this endemism is isolation of habitats, it can only be conjectured if the lack of endemism is brought about by hybridization and consequent swamping of species or by mere failure to evolve due to a freely interbreeding population. At least one case (that involving Q. peduncularis and its variety sublanosa) closely resembles hybridization and partial swamping of that form here regarded as the variety. If that is true it represents the only known case of hybridity in tropical American oaks.

Any species of Quercus is capable of surprising variation. Sometimes the variations involved are numerously represented, but frequently they occur as one or a few individuals. If by chance the variant resembles another species and this therefore makes its identification difficult, it is very apt to be termed a hybrid. Such a practice on the part of taxonomists identifying specimens to be placed in herbaria is highly confusing and cannot be discouraged too emphatically. To state that a puzzling form is a cross between two species which it resembles is admittedly a much easier disposition of a troublesome problem than painstakingly searching out its true identity. The cases of some herbaria are filled with specimens bearing the bar sinister, which, were they only correctly named, would go far toward presenting the student with a true picture of the range of variation to be expected within various species.

That the species concept here employed differs from that of Trelease is evidenced principally by the number of species placed in synonymy here. This difference of opinion seems to arise from the admission of greater intraspecific variation in the present work, and this in turn results from the availability of a greater quantity of specimens of many species than was formerly to be had. This wealth of material, for which Paul C. Standley is in large part responsible, has revealed the unreliable nature of many characters on which species have been based. There are still a few species that might conceivably break down should additional specimens appear.

In short, a very conservative attitude has been maintained in the delimitation of species. Although this has largely simplified the task of constructing a key to the species, the greater variability admitted has in some cases made it even more difficult. Furthermore, this conservative viewpoint has taken care of only those difficulties that arise from species being based upon too ephemeral characters. It has not eliminated those utterly different (and often only remotely related) species that are superficially so like one another as to make any distinction by key or description extremely difficult. It is hoped that the illustrations will supplement the key and descriptions sufficiently to deal with such problematic distinctions. 


\section{COMPARATIVE KNOWLEDGE OF AREAS}

Central America in general is not nearly so well known as regards Quercus as is Mexico. Yet, there are some areas in which extensive collections have been made, and there probably remains little yet to be discovered in the way of new species. Guatemala undoubtedly is the best known country. The State of Chiapas in Mexico and the Honduran countries are fairly well known, as is also Panama. There are a large number of collections from Costa Rica, but many of its problems are as yet very poorly understood. El Salvador and especially Nicaragua are very poorly known. Very few species are represented in the herbaria by more than two or three collections from these countries, and most are known only from the type collections.

The very limited knowledge of the oaks of certain countries may be attributed to the attitude of most collectors, since oaks are frequently neglected by them because of being considered difficult to name or because they labor under the misapprehension that fruiting specimens are essential. Oaks are relatively difficult to name, but they will not become less so unless they are collected for study. The species can be named almost as readily from sterile specimens as from fruiting specimens. It is very desirable to have fruit, and a very large collection totally lacking in fruiting specimens is sometimes rather trying, but lack of fruit is no excuse for failure to collect oaks whenever the opportunity presents itself. Flowering (staminate) specimens are worthless unless they are accompanied by mature leaves by which they may be identified. It is very desirable to collect flowering specimens whenever they may be definitely associated with mature leaves, in order that an analysis may be made of flowering characters.

\section{MORPHOLOGICAL BASIS OF CLASSIFICATION}

The differences in characters that have been used to characterize and distinguish the various categories within the genus are described and discussed as to significance and reliability in the following paragraphs.

HАвIт.-Although the various species of Quercus range from low shrubs to giant trees, there is insufficient information on habit available to afford any aid in classifying the Central American species. Some more northerly species are well known as strictly shrubby. Others may reach maturity as either shrubs or medium-sized or even large trees. Too frequently herbarium specimens are taken from juvenile plants with the information recorded merely as "a shrub." The data gleaned from herbarium labels have been recorded here merely as a contribution toward the fuller information which must eventually be gathered.

Twigs.- The twigs of the current season offer the most useful stem characters to be found. Although the thickness of the current twig may vary a great deal between normal and excessively vigorous shoots, the general trend of coarseness or of slenderness to be seen in a sufficiency of normal material is a useful aid in recognizing a species even though the exceptions often would bar its use in a key. The fluted form of most twigs (the presence of longitudinal sulcae) is not of much importance but has been included in the descriptions to serve for what 
little it may be worth. This character must be used with extreme caution, since fluting is sometimes brought about by the shrinking of very young twigs upon drying.

The nature and persistence of the pubescence of twigs in many cases are characters of great use in distinguishing closely related or merely similar species. Only rather extreme differences may be relied upon, however, and these are best employed only when several specimens are available to serve as a check upon the constancy of the character in that individual case. Less frequently useful is the presence and conspicuousness of lenticels. Rarely in Lepidobalanus but somewhat more commonly in Erythrobalanus, the presence of numerous and very conspicuous lenticels may serve to distinguish two rather similar species. Rare though the instances are, the character is a relatively constant one within the species.

BuDs. - No characters of profound importance are found in the buds of Quercus, but differences between species are often quite evident. Bud characters are more reliable in deciduous species than in evergreen ones, and they are more evident in temperate areas than in the Tropics. Immature buds may be very misleading, and it is often impossible to find mature buds on evergreen tropical species. The size of the terminal bud is often of diagnostic value, but this character may vary with the degree of vigor of the shoot, the maturity of the bud, and, toward the beginning of the growing season, the swelling of the bud. Shape is a more reliable character except insofar as it too may be affected by growth. However, both size and shape may be used to excellent advantage by choosing the most normal buds available. Pubescence, although less frequently presenting striking and representative differences, is fairly reliable when it is encountered.

ST'IPULES.-The stipules are of several more or less intergrading kinds. Associated with the lateral buds are pairs of ligulate stipules that in most cases are early caducous but that in a few species are constantly persistent. These are inserted one on each side of the bud. In their axils and lying between them and the bud is a second pair, usually shorter and more persistent and characterized by a broadened base and a somewhat subulate apex. This category of stipules is seldom if ever diagnostic and is not included in descriptions. The third class is comprised of the pairs of subulate appendages associated with the terminal buds and often the uppermost lateral (or alternate terminal) buds. These are more frequently persistent than the others and are the ones alluded to in the descriptions unless the lateral or ligulate stipules are specifically mentioned.

LeAves. - The most valuable characters in Quercus for distinguishing all classes of categories from subgenera to species are found in the leaves. Some of these are only superficial whereas others are very fundamental, but each may be quite readily evaluated.

The persistence of leaves is in many cases very useful. Those species that clearly indicate an evergreen habit or a deciduous habit are frequently distinguished from one another on this basis. However, the habit is not always apparent, because the old leaves may drop very shortly after the young ones unfold and because occasionally a deciduous species may undergo renewal of growth toward the end of the growing season, which gives the appearance of an evergreen habit. The character, therefore, is too difficult to apply and too inconstant 
to be used in a key except in rare instances, but it serves as supplementary evidence in the descriptions.

Although the texture of the leaf blades may vary somewhat with the habitat and age, this is not enough to invalidate the use of the character in many instances. Several groups of species are characterized by leaf thicknesses never acquired by others, no matter what the growing conditions might be.

Leaf size is too variable to be of critical value unless the discrepancies are very great and maintained throughout several specimens. Overlapping leaf sizes need not necessarily be regarded as breaking down the difference if the overlapping individuals are few in number.

Leaf shape is in many cases a trustworthy character, although in some species it counts for nothing. A difference in leaf shape unsupported by other characters is scarcely worth consideration. This character alone has been responsible for more synonyms than all others combined. Often, however, a perfectly legitimate species is based on leaf shape supported by several minor or almost intangible differences that scarcely lend themselves to description. Such instances must be treated solely by judgment after examining all available material.

The elements of leaf shape that often are of value as supplementary evidence are whether (1) the leaf is broadest above the middle or below, (2) the apex is acute or obtuse, (3) the base is cuneate, rounded, or cordate, (4) the margins are entire or toothed, and (5) the teeth are rounded (lobate), mucronate, or aristate-tipped. The presence of aristate tips on the teeth is an unfailing criterion of Erythrobalanus, and rounded, completely unappendaged lobes are likewise indicative of Lepidobalanus. Mucronately tipped teeth are characteristic of Lepidobalanus, but occasionally (in more northerly species not of Central America) these tips become quite long and subspinescent, but yet not aristate. (See pl. 1.)

The surfaces of the blade sometimes show characters of great value in distinguishing both species and series. The veins and secondaries are characteristically impressed on the upper side in some species or raised in others; they may be very prominent beneath or only slightly so. The lower surface of the lamina may be granular-bullate, low- or flat-bullate, or quite smooth. The bullate condition reaches its full development only in mature leaves, and therefore must be used with care. (See pl. 2.)

Pubescence may be of great significance as regards both its quantity and quality and its persistence. Characteristically tomentose lower leaf surfaces sometimes become nearly or quite glabrate. Some species, however, exhibit a surprising degree of constancy in this character. Still other species that are usually glabrate may occasionally retain a large share of their tomentum, especially in sheltered places on the under surface of the leaves. In a few instances this latter circumstance has been responsible for the creation of synonyms. Pubescence, like leaf shape, is a character subject to use only with careful judgment.

The number of principal veins, though a somewhat variable character, sometimes offers such great discrepancies as to constitute a significant character. The number of veins depends to some extent upon the relative length of the leaf, but this can be responsible for 
only minor differences in numbers. The configuration of the veins, i. e., whether or not they branch and obviously anastomose, is rather constant and may be depended upon where it presents a difference. Ordinarily, however, closely related species exhibit similar configuration. The prominence of the veins is discussed in a preceding paragraph in connection with the leaf surfaces, but there may be added to this the condition in which the veins are scarcely discernible and not very markedly raised on either surface. This occurs usually in rather thick leaves but certainly not in all thick leaves.

Petioles.-Except for such characteristics as pubescence (which ordinarily simulates that of the midribs or the twigs or both), a pruinose covering, and a winged condition (the blade apparently minutely decurrent on the petiole), scarcely any characters are to be found in the petioles other than length and thickness. Pubescence and the winged condition are subject to the same criticisms as leaf pubescence and shape, but they occasionally prove of value. Petiole length is usually no more dependable a character than leaf shape, but here, too, a great discrepancy is usually significant and especially so if it is constant and correlated with other differences.

CAtKins.-The staminate catkins of Quercus offer few if any characters for use in separating species or groups of species. The length and closeness or laxness of floral arrangement vary too much with degree of maturity to be of much use, although in a general way these characters show some individuality in certain groups. Similarly, the pubescence of the rachis and perianth and the exsertion of the stamens are in part a function of age and only slightly diagnostic of a few isolated entities.

The pistillate catkins are of use principally in judging whether or not the fruition is biennial. Catkins on twigs of the season lend weight to the evidence of acorns on twigs of the preceding year in deciding that the fruition is biennial. Because the length of peduncle and arrangement of flowers is often the same in the catkin stage as in fruit, these are not of much diagnostic value unless fruiting specimens are lacking.

Flowers.-Trelease credits the subgenus Erythrobalanus with glabrous anthers and mucronate or apiculate connectives as opposed to the often puberulent and notched or obtuse anthers of Lepidobalanus. However, he states that several series in Erythrobalanus have quite obtuse anthers, and puberulent anthers have been observed as well in that subgenus. The characters are mentioned in the species descriptions merely as a means of recording them in the hope that future collections may yield sufficient authentic flowering material to allow a complete analysis of the floral characters of the genus.

The pistillate flowers consist of a pistil seated in an involucre and bearing a united perianth of six lobes. The perianth adheres to the pistil up to the point of division of the styles. The lobing does not extend below this point. The subgenus Lepidobalanus is characterized by simple erect perianth lobes, but those of Erythrobalanus, although equally erect, are also furnished with a groove beneath the point of insertion. This appears as though each perianth lobe were basally appendaged or spurred and as though the spurs were then fused to form a ring. This then interlocks with the cup scales. Beneath the perianth, the three fused styles and the decurrent 
perianth bases form a stylopodium which persists as a knob on the apex of the mature fruit. This stylopodium is subtended basally by a three-carpellate ovary and apically by the three free styles and stigmas.

Besides the basally grooved perianth of Erythrobalanus the only character of the pistillate flower that is of value taxonomically is the nature of the stigmas. In Lepidobalanus the stigmas are broad, abruptly dilated, and reflexed or abruptly spreading; in Erythrobalanus they are more narrow, gradually dilated, and more gradually spreading.

It is clearly evident from the foregoing remarks that almost the only characters of taxonomic value to be found in the flowers are those that distinguish the two subgenera. An exception to this may be seen in the anthers, which are puberulent or glabrous and apiculate or not, irrespective of subgeneric lines (except that the apiculate anthers are largely confined to Erythrobalanus and the puberulent anthers to Lepidobalanus, there being exceptions in both cases).

Fruit.- In most cases the distinction between annual-fruited and biennial-fruited species is a good one. All the species of Lepidobalanus are strictly annual-fruited, but in Erythrobalanus certain series are annual, certain biennial, and still others contain both annualfruited and biennial-fruited species. In a few instances species ordinarily characterized by annual fruition may appear biennial fruited as a result of renewed growth late in the growing season. This circumstance likewise causes an apparent evergreen condition in characteristically deciduous species. Rarely the failure of the terminal bud to resume growth may give a biennial-fruited evergreen species the appearance of annual fruition.

Although length of peduncles is an unstable character, there is in Lepidobalanus a distinct break between obviously pedunculate species and those with subsessile fruit. In Erythrobalanus such a distinction apparently is impracticable.

The fruit is composed of a nut seated in an involucre. The nut (acorn) is derived from a three-carpellate ovary each carpel of which contains two or rarely three ovules. A single ovule develops, and the remainder abort and remain attached to the integument of the one functional ovule. The position of the aborted ovules, i. e., whether they adhere to the apex or the base of the functional ovule or in a lateral position, would probably be a character of considerable value, if its distribution in the genus were thoroughly known. In general, the abortive ovules of Lepidobalanus are strictly basal or somewhat lateral, whereas those of Erythrobalanus are apical in most species. A few groups of species in Erythrobalanus characteristically have basal or lateral ovules. However, in Q. acatenangensis, a species with ordinarily strictly apical abortive ovules, individuals have been observed with clearly basal ones. Also in Q. boqueronae, a species of Lepidobalanus, the aborted ovules are very deeply lateral or basal, the several sets of ovules being scattered along half the length of the functional ovule. It is clear, then, that the position of abortive ovules can scarcely be relied upon as a distinction between the subgenera, although it holds true in a high percentage of cases.

Much more trustworthy is the condition of pubescence of the inner surface of the acorn shell. In Lepidobalanus the shell is completely 
glabrous except for small tufts of tomentum in which are embedded the abortive ovules. These tufts are related rather to the ovules and the integument of the seed to which they adhere than to the acorn shell. In Erythrobalanus, on the other hand, the shell is without exception densely and permanently covered with a thick, feltlike layer of matted creamy or silvery tomentum. This is an unfailing distinction between the subgenera.

The cotyledons and radicles of the species of Erythrobalanus and of all but a few species of Lepidobalanus are very constant in their relative positions. The cotyledons are equal in size and similar in shape, and the radicle is in an apical position and apically directed. In the several species comprising the proposed genus Macrobalanus of Schwarz the cotyledons are unequal in length, the radicle lying at the apex of the shorter cotyledon and therefore in a lateral position and obliquely directed. This character is apparently constant for most of the species of this group of which fruit is known, but the recently discovered $Q$. panamandinaea has cotyledons of both types.

The involucre or acorn cup consists of a saucer-shaped to deeply cup-shaped structure the outside of which is covered by a spiral series of imbricate scales. Trelease $(6, p p .8-10)$ calls attention to what he terms "acornlike galls", which occur occasionally in the axils of the cup scales. He also mentions the rare replacement of the scales by leaves as evidence of their foliar origin, which he says lends indirect support to the belief that the acorn cup is "constituted by the fused secondary branches of a dichasium." Whether the inflorescence from which the cup is derived be a dichasium or of some other type is not clearly indicated by the teratology of the cup. The spiral arrangement of the scales, which is clearly evident in certain loosely formed cups such as those of $Q$. humboldtii, might as readily indicate the cup to be a contracted spike. This would bring the pistillate prototype nearer the author's present conception of the staminate inflorescence.

At the same time the occurrence of several cups on a single peduncle would suggest origin from a compound inflorescence. The very compact fruiting peduncles of several Asiatic species, which simulate a cone with numerous acorns embedded in a matrix of barely distinguishable cups, is very strongly suggested in a teratological specimen of Q. humboldtii (Bro. Thomas 766). In this the scales of the cups are not only foliar in nature but each bears in its axil a perfectly formed pistillate flower seated in its own small cup. This may be interpreted as meaning that each cup scale is fitted with a reduced and normally nonfunctional bud in its axil, which represents an obsolete branch of a formerly compound inflorescence.

The acorn cups of Quercus offer some very valuable characters for the distinction of groups of species. The subgenus Lepidobalanus is characterized by scales which are loosely appressed, rather pointed at the apex, and more or less keeled or corky-thickened at the base. Those of Erythrobalanus are characteristically thin and closely appressed, blunt or rounded at the apex, and not thickened or keeled basally. Certain groups of species in Erythrobalanus that are otherwise orthodox have loosely appressed scales, and certain others frequently show an apparent basal thickening that is actually a partial development of the axillary buds beneath the scales and results 
in a warty appearance as opposed to the regularly thickened scales of Lepidobalanus. A few species of Erythrobalanus have the cup scales actually thickened basally. In some species of Lepidobalanus the mature cups are inflated and the margins inrolled against the acorn. Occasionally the margins are very minutely inrolled without any evidence of inflation of the cups. In others the cup flares out as though it were dehiscing so that the entire structure becomes a disk. All these characters must be treated with extreme care, for degree of maturity is often distinctly a function of these variations. Only the form of the scales seems to remain relatively constant within a species. (See pl. 3.)

Another character of the cup is the degree of inclusion of the acorn at maturity. This normally varies within the genus from completely covered acorns to those included at the base only. In the Central American flora very few species occur with acorns more than about two-thirds included. This character also is a function of maturity and should be regarded with considerable suspicion unless a large series of fully mature fruit is available. For instance, several of the synonyms of $Q$. corrugata arose through the description of perfectly mature fruits of that species, the species previously having been known only from immature specimens. Furthermore, the character is not necessarily a constant one even if fully mature fruit is available in abundance. The several clearly conspecific forms of Q. pilicaulis have cups and acorns which differ widely and in a most haphazard manner. The fruiting characters in this case must be held secondary to the more fundamental of the several vegetative characters.

\section{METHODS}

Aside from the consideration of the anatomical characters of the wood, a study that was carried on concurrently with this one, no innovations have been introduced in the taxonomic procedure. The complete aggregation of specimens here cited was gathered together at one time and studied as a single collection over a period of several months. This method served to avoid many errors and much lost effort such as one experiences in studying first one collection, then a second, and finally attempting to correlate with these a third.

Since Trelease's monograph contains photographs of the types of nearly all the species then known, no special effort was made to choose types for the illustration of this publication except in the case of new species or those published subsequent to Trelease's volume. The policy followed was rather to select the most representative specimens and those most illustrative of common variations, relationships, distinctive characters, etc. The illustrations are meant to serve less as a record than as a supplement to the key in the identification of species.

If the type or an isotype of a species is cited under specimens examined, it is not mentioned elsewhere. Otherwise, the type is designated following the data on the range of each species. 


\section{SYSTEMATIC TREATMENT}

QUERCUS L., Gen. Pl. ed. 5. 431. 1754.

Cerris Raf., Alsog. Amer. 29. 1838.

Scolodrys Raf., Alsog. Amer. 29. 1838.

Macrobalanus Schwarz, Notizbl. Bot. Gart. Mus. Berlin-Dahlem 13: 8. 1936.

Erythrobalanus Schwarz, Notizbl. Bot. Gart. Mus. Berlin-Dahlem 13: 8. 1936.

Shrubs to large trees. Pith star-shaped, continuous; wood usually hard with both uniseriate and multiseriate rays, vessels grouped in a matrix of wood-parenchyma, either diffuse-porous or ring-porous, often plugged by tyloses. Buds crowded toward the ends of the usually fluted twigs. Leaves alternate, usually distinctly petioled, never quite sessile, simple, entire or toothed or pinnately lobed, pinnately veined; the stipules associated with the buds rather than the leaves, subulate to ligulate, promptly caducous or sometimes persistent. Monoecious; staminate flowers in elongate flaccid catkins, apetalous, the calyx of 5 lobes fused into a more or less bowl-shaped perianth enclosing 5 to 10 free stamens with short anthers and slender filaments; pistillate flowers in a reduced catkin with a stiff woody rachis either short or long and 1- to several-flowered, calyx of 6 sepals adherent to the bases of the styles and fused into a tube, pistil of 3 carpels comprising a single 3-celled ovary (each cell containing 2 ovules) and 3 free styles which are ventrally stigmatic toward the dilated apex. Fruit 1-celled and 1-seeded, the 5 remaining ovules aborted and adhering to the developed seed, the seed enclosed in a shell (forming a nut or acorn) and seated in a cup or involucre formed (in our species) of scales (each with a more or less aborted bud in its axil), growing from a compressed inflorescence, the cup enveloping the whole nut or covering it only at the base.

Type species: Quercus robur L.

\section{KeY to SPEcies}

1. Bark rather soft gray and scaly, leaves if toothed only mucronate-tipped or rounded, never spinose- or aristate-tipped, stigmas abruptly dilated on short styles, fruit annual, cup scales usually prominently thickened basally and loosely appressed apically, acorns with the shell glabrous on the inner surface, abortive ovules basal. (See also p. 15).

I. LEPIDOBALANUS. White Oaks.

2. Twigs of the season persistently and densely fulvous-tomentose.

3. Leaves oblanceolate, tapering to the cuneate or narrowly rounded base, coarsely toothed above the middle, petioles 3 to $5 \mathrm{~mm}$. long.

4. Q. OOCARPA.

3. Leaves obovate to elliptic-oblanceolate, not tapering, the base rather broad, cuneate to cordate, subentire or low-toothed, petioles over 6 (usually over 10) mm. long.

4. Leaves deeply broad-cordate...... Q. SEIBERTII.

4. Leaves cuneate to truncate at base.

5. Leaves short-acuminate or merely acute, veins 18 to 20 on each side, petioles 12 to $25 \mathrm{~mm}$. long _........ 1 . Q. INSIGNIS.

5. Leaves long-acuminate, veins about 13 to 18 on each side, petioles 6 to $12 \mathrm{~mm}$. long .

2. Twigs of the season glabrate or sparingly pubescent or gray-tomentose.

6. Leaves with persistent unbroken short tomentum beneath or the lower surface canescent with minute appressed stellate hairs.

$323472^{\circ}-42-2$ 
7. Leaves basally cordate, with short spreading creamy tomentum beneath, veins 11 to 15 on each side _...... 15. Q. PURULHana.

7. Leaves basally cuneate to subobtuse, appressed-canescent beneath, veins 6 to 8 on each side........ Q OLEIOIDES.

6. Leaves glabrate or pubescent beneath but not with short dense tomentum or appressed stellate hairs.

8. Leaves completely glabrate.

9. Leaves long-acuminate, entire, cup scales tomentose at base only, the apices glabrous, thin, and loosely appressed.

8. Q. PANAMANDinaea.

9. Leaves not acuminate, or if so then coarsely toothed, cup scales pubescent all over.

10. Leaves oblanceolate or lanceolate, attenuate, coarsely severaltoothed above the middle.

11. Petioles 1 to $4 \mathrm{~mm}$. long. 5. Q. PILARIUS.

11. Petioles 15 to $40 \mathrm{~mm}$. long...... Q. Corrugata.

10. Leaves typically oblong or lance-elliptic, abruptly acute or obtuse, coarsely few-toothed toward the apex or entire.

12. Leaves cuneate at base, glossy beneath, fruit large (cups over $20 \mathrm{~mm}$. broad), solitary or paired_._-7. Q. BOQUERONAE.

12. Leaves broadly rounded or cordate at base, glaucous and dull beneath, fruit small (cups 10 to $14 \mathrm{~mm}$. broad), clustered.

18. Q. SEBIFERA.

8. Leaves villous or tomentose beneath or at least the midrib strigose or stellate-tomentose.

13. Fruit large (acorns 2.5 to $3 \mathrm{~cm}$. broad).

14. Leaves obovate to elliptic-oblanceolate, not markedly tapering, the base rather broad, cuneate to cordate, obscurely lowtoothed, petioles 6 to usually 10 or $12 \mathrm{~mm}$. long.

3. Q. DAVIDSONIAE.

14. Leaves oblanceolate, tapering to the cuneate or narrowly rounded base, coarsely toothed above the middle, petioles 3 to 5 mm. long _......... QOCARPA.

13. Fruit smaller (acorns rarely as much as $2 \mathrm{~cm}$. broad at maturity).

15. Leaves very thick and leathery, markedly impressed-veiny above, evidently reticulate-veiny beneath, strongly cordate, sparsely tomentose beneath................ Q. PILICAULIS

15. Leaves relatively thin, veins not markedly impressed above nor evidently reticulate beneath, or if leaves thick and impressedveiny above then persistently and densely long-tomentose beneath or not cordate.

16. Leaves waxy-glaucous beneath.

17. Petioles 15 to 25 (rarely only 10 ) $\mathrm{mm}$. long, leaves ovate to elliptic, entire or apically few-toothed, very prominently veiny beneath _......... 10 . Q. POLYMORPHA.

17. Petioles not over $7 \mathrm{~mm}$. long, leaves narrowly oblong or the whole margin toothed.

18. Leaves ovate to oblanceolate _._._.14. Q. PEDUNCULARIS.

18. Leaves oblong to lanceolate_......_.16. Q. vicentensis.

16. Leaves not waxy-glaucous beneath or this obscured by loose long tomentum.

19. Leaves thick, impressed-veiny above and usually loosely long-tomentose beneath _...... 14. Q. PEDUNCULARIS.

19. Leaves if thick not markedly impressed-veiny above, glabrate or merely villous or sparsely tomentose beneath, the pubescence in no case obscuring the surface.

20. Leaves regularly and usually repandly 10 - or 12-toothed on each side corresponding to the veins, or merely erosely crenate.

21. Leaves rather thick and quite leathery, erosely crenate, drying yellowish-brown _..._13. Q. SEGoviensis.

21. Leaves thin, usually regularly round- or acute-toothed, drying green.

14a. Q. PEDUNCULARIS var. SUBLANOSA.

20. Leaves entire or irregularly few-toothed above the middle. 
22. Leaves thick and leathery, glabrate except for the veins, the margins markedly revolute, entire or finely toothed.

23. Leaves more than twice as long as broad, veins and reticulum very prominent beneath (plants of Guatemala) _........... Q. PACAYANA.

23. Leaves less than twice as long as broad, veins somewhat raised but reticulum very obscure beneath (plants of Costa Rica and Panama).

12. Q. COPEYENSIS.

22. Leaves rather thin or if somewhat leathery then persistently stellate-pubescent beneath and coarsely few-toothed or undulate toward the apex.

24. Leaves thin, glabrate except for the strigose midrib and veins or rarely fulvous-stellate-tomentose along the midrib beneath, subentire, twigs strikingly whitened or if brownish then persistently villous, the lenticels not evident__ 9. Q. AÁATA.

24. Leaves somewhat thickened and leathery, stellatepubescent beneath, coarsely few-toothed toward the apex, twigs brown with pale lenticels and glabrate...... Q. VICENTENSIS.

1. Bark rather hard, black, and furrowed but scarcely scaly, leaves if toothed aristate-tipped, never round-lobed, stigmas gradually (or rarely abruptly) dilated, on long styles, fruit biennial or annual, cup scales scarcely thickened basally (or if so the leaf characters definitely as here described) and usually tightly appressed apically, acorns with the shell tomentose on the inner surface, abortive ovules usually apical.

II. ERYTHROBALANUS. Black Oaks.

25. Leaves entire or the margins crisped but in no way toothed or aristate.

26. Apex broadly rounded, or if narrowly rounded not aristate.

27. Blades granular-bullate beneath, from tomentose becoming more or less glabrate.

28. Cup scales very loosely appressed, cups $25 \mathrm{~mm}$. broad.

28. Cup scales closely appressed, cups at most $15 \mathrm{~mm}$. broad.

33. Q. TRISTIS.

27. Blades smooth beneath, that is not bullate, glabrous or at most tufted in the axils of the veins, fruit small and the cup scales very closely appressed.

29. Blades very shiny on both surfaces but especially above, very thick and hard, the mature cups usually $15 \mathrm{~mm}$. broad, saucershaped . 25. Q. DURATIFOLIA.

29. Blades dully lustrous on both surfaces or the under surface waxyglaucous, leathery but scarcely hard, the mature cups seldom over $10 \mathrm{~mm}$. broad, cup-shaped.

26. Apex acute and aristate-tipped or acuminate.

30. Blades low-bullate or granular-bullate beneath.

31. Leaves variously pubescent or glabrate but not persistently loosetomentose beneath.

32. Petioles over $5 \mathrm{~mm}$. long, or if shorter then the leaves toothed and aristate...

32. Petioles 2 to $3 \mathrm{~mm}$. long, leaves never toothed.

33. Leaves not over twice as long as broad, acute but not longacuminate, very thick and leathery 22 . Q. COSTARICENSIS.

33. Leaves over twice as long as broad, long-acuminate or rarely only acute, rather thin but firm _...23. Q. IRAzUENSIS.

31. Leaves persistently loose-tomentose beneath.

34. Twigs persistently velvety-tomentose, waxy-glaucous as well as bullate where denuded........ 34 . QRACHYSTACHYS.

34. Twigs glabrate or scurfy but not velvety, leaves not waxy-glaucous beneath.

35. Leaves rather sparsely short-tomentose or merely crispedvillous beneath, at most low-bullate $\_$45. Q. CRISPIPILIS.

35. Leaves rather densely thick-tomentose or eventually somewhat glabrate but never sparsely or short-tomentose, granularbullate........ 45a. Q. CRISPIPILIS var. PANNOSIFOLIA. 
30. Blades smooth beneath, that is not bullate.

36. Leaves linear-lanceolate or flagellate, at least 5 times as long as broad and very long-tapering at the apex, veins 18 to 24 on each side and issuing at an angle of 80 to 85 degrees from the midrib_........................ 36 . Q. FLAGELLIFERA.

36. Leaves not linear-lanceolate or flagellate, less than 5 times as long as broad and if very long-tapering at the apex, then broadened below the middle, veins seldom over 15 on each side and seldom issuing from the midrib at an angle as great as 80 degrees.

37. Fruit biennial.

38. Leaves acuminate or narrowly lanceolate.

39. Petioles 5 or rarely $10 \mathrm{~mm}$. long, acorns 25 to $30 \mathrm{~mm}$. long and 22 to $26 \mathrm{~mm}$. broad _..._._. 32 . Q. CRISPIFOLIA.

39. Petioles 10 or usually 15 to $25 \mathrm{~mm}$. long, if shorter then the leaves toothed, acorns up to $17 \mathrm{~mm}$. long and $14 \mathrm{~mm}$. broad.

40. Leaves glabrous beneath except for axillary tufts, about 1.5 to $2 \mathrm{~cm}$. broad ...... 35 . Q. ACATENANGENSIS.

40. Leaves resinous-puberulent beneath, 3 to 5 (rarely less) $\mathrm{cm}$. broad _...

38. Leaves oblong or ovate, neither acuminate nor lanceolate, abruptly aristate at apex, crisped- or woolly-pubescent beneath.

41. Leaves rather sparsely short-tomentose beneath, smooth or at most low-bullate_..._....._. 45 . Q. CRISPIPILIs.

41. Leaves rather densely thick-tomentose beneath or eventually glabrate but never sparsely or short-tomentose, granu-

37. Fruit annual. lar-bullate_.__ 45a. Q. CRISPIPILIS var. PANNOSIFOLIA.

42. Cup scales very loosely appressed.

43. Leaves long-acuminate or tapering at apex (species of Colombia) ..... Q. HUMBOLDTII.

43. Leaves merely acute (species of Guatemala).

42. Cup scales rather closely appressed.

21. Q. BENTHAMI.

44. Twigs short-velvety-tomentose or tardily glabrate.

24 . Q. HONDURENSIS.

44. Twigs variously glabrous or from loosely tomentose becoming glabrate, but not velvety.

45. Leaves long-acuminate.

46. Petioles over $5 \mathrm{~mm}$. long.

47. Acorns 25 to $30 \mathrm{~mm}$. long and 22 to $26 \mathrm{~mm}$. broad (species of Guatemala and Mexico).

32. Q. CRISPIFOLIA.

47. Acorns not over $15 \mathrm{~mm}$. long and $12 \mathrm{~mm}$. broad, peduncles not over $10 \mathrm{~mm}$. long (species of Costa Rica and Panama) _......30. Q. SEemanni. 46. Petioles 2 to $4 \mathrm{~mm}$. long, peduncles 10 to $25 \mathrm{~mm}$. long, leaves very long-taper-pointed.

31. Q. GULIELMi-TRELEASEI.

45. Leaves short-acuminate or merely acute.

48. Leaf margins flat, neither markedly crisped nor strongly revolute.................. 28 . BORUCASANA.

48. Leaves crisped and coarsely revolute.

49. Veins issuing at an angle of 75 or 80 degrees from the midrib, acorns not over $11 \mathrm{~mm}$. long and $10 \mathrm{~mm}$. broad_..._._. 27. Q. EUGENIAEFOLIA.

49. Veins issuing at an angle of 45 or 50 degrees from the midrib, acorns about $18 \mathrm{~mm}$. long and broad.

29. Q. TONDUZII.

25. Leaves toothed or the margins aristate.

50 . Leaves very large, thin, characteristically obovate, coarsely toothed or merely long-aristate above the middle, the lower surface persistently and densely short-tomentose but the veins glabrous.

46. Q. Candicans.

50. Leaves medium-sized or if large not short-tomentose on the lower surface, variously woolly to glabrous. 
51. Leaves persistently densely loose-woolly beneath or partially glabrescent, bullate-granular, fruit biennial.

52. Twigs coarse ( 3 to $5 \mathrm{~mm}$. thick), persistently velvety-tomentose, leaves waxy-glaucous beneath where denuded.

34. Q. BRACHYSTACHYS.

52. Twigs 2 or rarely $3 \mathrm{~mm}$. thick, loosely tomentose or glabrate or rather persistently pubescent but not velvety, leaves not waxy-glaucous beneath when denuded _.45a. Q. CRISPIPILIS var. PANNOSIFOLIA.

51. Leaves glabrous or loosely tomentose and soon glabrate or with axillary tufts or puberulent on the blade beneath, smooth beneath or if bullate-granular then the fruit annual, otherwise fruit either annual or biennial.

53. Leaves bullate-granular beneath, strongly impressed-veiny above.

33. Q. TRISTIS.

53. Leaves smooth and not at all bullate beneath, slightly if at all impressed, veiny above.

54. Twigs densely fulvous-tomentose, persistently so or glabrate.

55. Twigs from densely short-velvety-tomentose soon glabrate, leaves coarsely and divergently toothed above the middle, only locally pubescent $\ldots . . . . . . .40$. Q. BRENESII.

55. Twigs loosely and persistently tomentose, leaves coarsely toothed or aristate throughout, loosely tomentose all over, soon glabrate .............. 41 . Q. TENUIARISTATA.

54. Twigs sparsely if at all pubescent and soon glabrate.

56. Leaves very narrow, elongate, and taper-pointed, finely toothed or merely aristate, petioles 1 to $3 \mathrm{~mm}$. long.

57. Leaves taper-pointed at both ends.

58. Fruit obviously peduncled, cups often constricted at base.

40. Q. BRENESII.

58. Fruit subsessile, cups rounded at base _. 44. Q. GRACILIOR.

57. Leaves narrowed toward the base but finally rounded or abruptly cuneate, in no sense taper-pointed basally.

36. Q. FLAGELLIFERA.

56. Leaves broad or if narrow not as much as 5 times as long as broad and not taper-pointed, coarsely toothed or if merely aristate then not elongate, petioles much over $5 \mathrm{~mm}$. long or else the blades coarsely toothed.

59. Fruit very large (acorns over $3 \mathrm{~cm}$. broad), cup scales corkythickened basally at maturity, fruit biennial.

37. Q. SKINNERI.

59. Fruit moderate or small (acorns usually less than $2 \mathrm{~cm}$. broad), cup scales thin and flat or if basally inflated this resulting from swelling of the buds in their axils and rarely from their own thickening.

60. Acorns about $2 \mathrm{~cm}$. broad, nearly round, acorn shells $3 \mathrm{~mm}$. thick or more, very hard, cup scales corky-thickened basally at maturity, fruit biennial _ 37. Q. SKINNERI.

60. Acorns less than $2 \mathrm{~cm}$. broad, ovoid or depressed, never spheroid, acorn shells $1.5 \mathrm{~mm}$. thick or less, cup scales basally thickened or thin at maturity.

61. Fruit biennial.

62. Cup scales markedly keeled or thickened basally, cup margins not inrolled, leaves thin, evenly and coarsely toothed with long-aristate tips throughout_........... 38 . Q. MONSERRATENSIS.

62. Cup scales flat at maturity, leaves rather thick, not evenly and coarsely toothed throughout nor with prominent long aristate.

63. Leaves not markedly aristate-tipped at the acute apex, glabrous or with axillary tufts beneath, cup margins not inrolled.

35. Q. ACATENANGENSIS.

63. Leaves markedly aristate-tipped at the acute apex, characteristically yellow-glandular-puberulent beneath or rarely glabrate except for axillary tufts, cup margins coarsely inrolled.

39. Q. CONSPERSA. 
61. Fruit annual.

64 . Petioles $5 \mathrm{~mm}$. long or less, leaves coarsely and divergently toothed above the middle.

40. Q. BRENESII.

64. Petioles usually over $10 \mathrm{~mm}$. long, leaves toothed or at least aristate throughout or if entire below the middle then the toothing merely aristate and not coarse.

65. Leaves coarsely toothed throughout and the teeth long-aristate, petioles 20 to $30 \mathrm{~mm}$. long and very slender, glabrous_._-42. Q. PAXTALENsis.

65. Leaves merely aristate from the margins or from very low teeth, petioles seldom over $15 \mathrm{~mm}$. long, from tomentose becoming glabrate.

43. Q. ANGLOHONDURENSIS.

I. SUBGENUS LEPIDOBALANUS (Endl.) Oerst., Vidensk. Medd. Naturh. Foren. Kjobenh. 1866: 65. 1866.

Lepidobalanus Endl., Gen. Pl. Sup. $4^{2}: 24.1847$ (as subdirision of Quercus without indication of rank).

Macrobalanus Oerst., K. Danske Vidensk. Selsk. Skrift. 9: 370. 1871 (as subgenus).

Leucobalanus Engelm., Trans. Acad. Sci. St. Louis 3: 381. 1876 (as subgenus).

Macrobalanus Schwarz, Notizbl. Bot. Gart. Mus. Berlin-Dahlem 13: 8. 1936 (as genus).

Shrubs or often large trees with the bark usually rough, scaly, soft, and gray or white; wood pale, the larger ducts often plugged by tyloses, the smaller (summer wood) ducts thin-walled and angular or thick-walled ( $3 \mu$ or more) and round; leaves entire, often round-lobed (in this case usually deciduous) or at most serrate with the teeth mucronate-tipped (in this case either deciduous or evergreen), never aristate- or spinose-tipped; stamens 7 to 9 , anthers rounded, emarginate; styles short, the stigmas short, broad, horizontally spreading; fruit always annual (maturing in 1 year), cup scales elongate-narrowed, often corky-thickened basally, abortive ovules basal, more or less immersed in tomentum, the inside of the acorn shell otherwise glabrous.

Type species: Quercus robur L.

Series Insignes Trel., Mem. Nat. Acad. Sci. 20: 42. 1924.

Large trees with coarse fulvous-tomentose twigs; stipules caducous or persistent; leaves large, deciduous (?), typically oblanceolate to obovate, ovate or elliptic, subentire or serrate, glabrate above and usually pubescent beneath; petioles short or moderate; fruit large, the cup scales much thickened basally and loosely appressed or spreading apically, cotyledons unequal.

Range: Veracruz to Guatemala and Panama.

Includes: Quercus insignis Mart. and Gal. (type), Q. seibertii C. H. Mull., and $Q$. davidsoniae Standl.

1. Quercus insignis Mart. and Gal., Bul. Acad. Brux. 10 ${ }^{1}$ : 219. 1843.

Quercus schippii Standl., Carn. Inst. Wash. Pub. 461: 53. 1936.

Large tree to $30 \mathrm{~m}$. tall with a trunk diameter of $1 \mathrm{~m}$. Twigs 4 to $6 \mathrm{~mm}$. thick, fluted, densely yellow-tomentose the first year, becoming 
glaucous or gray the second year with evident white lenticels. Buds 10 (or becoming 15) $\mathrm{mm}$. long, ovoid, glabrous; stipules caducous or persistent for a time, about $8 \mathrm{~mm}$. long, subulate to ligulate, appressedpubescent dorsally. Leaves deciduous (?), rather thick and hard, large (10 to 20 or $28 \mathrm{~cm}$. long, 4 to 9 or $10 \mathrm{~cm}$. broad), elliptic or oblong-elliptic to usually narrowly obovate, apically acute but the tip finally minutely rounded, basally cuneate to rounded or truncate, subentire to undulately wavy-margined or rarely toothed, margins very minutely revolute, upper surface somewhat shining, glabrous or puberulent along the principal veins, the midrib obviously tomentose, lower surface dull, fulvous-villous-tomentose or glabrate; veins 18 to 20 on each side, obviously branched and anastomosing near the margin, minutely raised above and very prominent (as is also the reticulum) beneath; petioles 8 to 15 or even $25 \mathrm{~mm}$. long, 2 to $3 \mathrm{~mm}$. thick, densely fulvous-tomentose. Catkins? Fruit annual, solitary, subsessile, very large at maturity; cups 4 to $8 \mathrm{~cm}$. broad, saucer-shaped or deeper, often contracted at base, the scales very coarse, oblong or attenuate, much thickened and very broad at base, the narrow apices loosely appressed or spreading, from densely fulvous-tomentose nearly glabrate in age; acorns 4 to $7 \mathrm{~cm}$. broad, depressed-hemispheric, longitudinally striate, very thick-shelled, about one-half included. (See pls. 4 and 5.)

Range: Southern Sierra Madre Oriental region of Mexico and forest of the British Honduras and Guatemala boundary region (above 800 m.); type from Volcan Orizaba, Veracruz, Mexico (Galeotti 123).

Quercus insignis is reported to be" occasional" in the Honduras-Guatemalan locality. This species is most closely related to Q. seibertii from which it is distinguished by its numerous principal veins, its undulate leaf margins, its noncordate leaves, and its subsessile fruit. It is much more difficult to distinguish from the somewhat polymorphic $Q$. davidsoniae, to which it is actually not so closely related. The attenuate apices and prominent teeth of $Q$. davidsoniae usually may be trusted to distinguish it from $Q$. insignis.

Specimens examined:

BRITISH HONDURAS.- “Camp 36” British Honduras-Guatemala Boundary Survey, June 19, 1934, Schipp 1247 (AA, F [2], MBG [2], Mi, NY); June 23, 1934, Schipp 1248 (AA, F [type of Q. schippii], MBG, Mi [2], NY).

\section{Quercus seibertii sp. nov. ${ }^{5}$}

Large tree to $25 \mathrm{~m}$. Twigs very coarse (4 to $7 \mathrm{~mm}$.), markedly fluted, densely fulvous-tomentose, glabrate and gray the second year with conspicuous white lenticels. Buds glabrate, for a time surrounded by ligulate stipulelike scales; the stipules persistent for a time, 10 to $12 \mathrm{~mm}$. long, ligulate, dorsally appressed-pubescent. Leaves deciduous, thin but firm, large $(12$ to $20 \mathrm{~cm}$. long, 5 to $11 \mathrm{~cm}$. broad), elliptic or broader above the middle, apically acute or broadly rounded, broadly and markedly cordate, entire, margins minutely revolute, upper surface somewhat shining, glabrous or glabrate from sparsely stellate-puberulent, midrib densely and conspicuously fulvous-tomentose, lower surface dull, minutely stellate-puberulent,

\footnotetext{
5 Quercus seibertii sp. nov.-Arbor grandis, ramuli 4-7 mm. crassi dense fulvo-tomentosi, folia decidua 12-20 cm. longa 5-11 cm. lata elliptica acuta vel rotundata cordata integra sparse puberulenta vel glabrata, venis utrinque 13-15 ramosis et anastomosantibus subtus prominentibus, petioli 12-18 mm. longi dense fulvo-tomentosi, amenta feminea 3-9 cm. longa 3-6 flora, fructus annuus brevipedunculatus, cupula 3-4 cm. lata, squamae elongato-oblongae non appressae.
} 
the veins and midrib rillous; veins about 13 to 15 on each side, much branched and obviously anastomosing near the margin, scarcely raised or even impressed above and very prominent (even to the reticulum) beneath; petioles 12 to $18 \mathrm{~mm}$. long, 1.5 to $3 \mathrm{~mm}$. thick, densely fulvous-tomentose. Pistillate catkins 3 to $9 \mathrm{~cm}$. long, 3 to 6 flowers scattered on the pubescent peduncle, all except the basal 1 or 2 flowers aborting. Fruit annual, large; cups 3 to $4 \mathrm{~cm}$. in diameter, openly shallow-goblet-shaped, the scales elongate-oblong, somewhat spreading or loosely appressed, finely pubescent, the lower ones dorsally thickened. (See pls. 6 and 7.)

Range: Chiriqui Province of Panama (1,300 to 1,900 m.).

Quercus seibertii is most closely related to Q. insignis from which its long peduncles and entire cordate leares with fewer veins amply distinguish it. These characters distinguish it equally well from Q. davidsoniae, to which it is less closely related.

Specimens examined:

PANAMA.-Prov. Chiriqur; upper valley of Rio Chiriqui Viejo, vicinity of Monte Lirio, June 27 to July 13, 1935, Seibert 225 (AA [type], MBG [2], NY); January 16, 1939, Allen $1596^{\circ}$ (MBG, USNA).

3. Quercus davidsoniae Standl., Field Mus. Bot. Ser. 22: 14. 1940.

"Very tall" tree or reaching only $8 \mathrm{~m}$. Twigs moderately coarse ( 2 to $5 \mathrm{~mm}$. thick), fluted, from sparsely fulvous-tomentose glabrate and gray or brown with evident light lenticels. Buds round, glabrate; stipules caducous, about $10 \mathrm{~mm}$. long, ligulate, dorsally tomentose. Leaves deciduous (?), thin but firm, 9 to usually $15 \mathrm{~cm}$. long, 4 to 8 cm. broad, oblanceolate-oblong or oblong-elliptic, attenuately acute or merely acute at apex, cuneate or rounded or truncate at base, scarcely cordate, mucronately or rarely crenately toothed especially above, the teeth coincident with the veins, margins minutely revolute, upper surface somewhat shining, from very sparsely puberulent quickly glabrate, lower surface somewhat shining, from puberulent glabrate or the veins pubescent; reins about 13 to 18 on each side, much branched and obviously anastomosing but ultimately passing into the teeth where those are present, scarcely raised above but quite prominent (including the reticulum) beneath; petioles 6 to $12 \mathrm{~mm}$. long, about $1.5 \mathrm{~mm}$. thick, from puberulent or tomentose becoming glabrous. Catkins? Fruit annual, solitary on a peduncle about 1.5 cm. long; cups $3.5 \mathrm{~cm}$. broad, hemispheric, scales deltoid-ovate to oblong, attenuately narrowed but finally obtuse, thickened basally, loosely appressed, densely sericeous-tomentose; acorns (immature) subglobose, about $2.5 \mathrm{~cm}$. long and $3 \mathrm{~cm}$. broad, from buff-sericeous becoming glabrate. (See pls. 8 and 9 ).

Range: Chiriqui Province of Panama to central Costa Rica $(1,200$ to $1,900 \mathrm{~m}$.).

Quercus davidsoniae is a polymorphic species, and it is therefore sometimes difficult to distinguish. Its specific relationship within the series is not clear, but there is no doubt that it belongs in this group. Its toothed leares and glabrescent twigs readily distinguish it from the other species of the series.

Specimens examined:

COSTA RICA.-Prov. San Jose: between Aserri and Tarbaca, February 12, 1924, Standley 34186 (US); region of Zarcero, August 13, 1937, A. Smith 141 (F [3]); A. Smith $17 \%$ (F, MGB); May 30, 1941, A. Smith 2769 (USNA).

PANAMA.-Prov. Chiriqui: Distr. de Boquete, Boquete, July 6, 1938, Davidson 864 (F [type]). 
Series Oocarpae Trel., Mem. Nat. Acad. Sci. 20: 43. 1924.

Large trees with rather coarse villous or glabrate twigs; buds ovoid or subglobose, the stipules caducous or persistent; leaves large, evergreen(?), typically oblanceolate, coarsely toothed; fruit large, cotyledons unequal.

Range: Guatemala to Panama.

Includes: Q. oocarpa Liebm. (type) and Q. pilarius Trel.

4. Quercus oocarpa Liebm., Overs. Danske Vidensk. Selsk. Forhandl. 1854: 184.1854.

Q. warscewiczii Liebm., Overs. Danske Vidensk. Selsk. Forhandl. 1854: 187.1854.

Q. yunckeri Trel. in Yuncker, Field Mus. Bot. Ser. 17: 358. 1938.

Small or large tree (6 to $25 \mathrm{~m}$.). Twigs rather coarse (3 to $5 \mathrm{~mm}$.), fluted, from densely fulvous-tomentose becoming glabrate and gray or light brown with a few scarcely evident lenticels. Buds oblong, acute, about $4 \mathrm{~mm}$. long, glabrous, with ligulate villous stipules 10 to $13 \mathrm{~mm}$. long and persistent. Leaves apparently evergreen, thin and papery or rather firm, 10 to 25 or rarely $30 \mathrm{~cm}$. long, 3 to 10 or even $14 \mathrm{~cm}$. broad, oblanceolate to obovate or narrowly elliptic, attenuately acute at apex, narrowly rounded or cuneate at base, undulately or sharply low-dentate except the entire base, margins very minutely somewhat revolute, upper surface somewhat shining, glabrous or usually glabrescent from minutely puberulent, the midrib often persistently fulvous-tomentose, lower surface dull, persistently and sparsely villous especially on the veins and reticulum; veins about 14 to 22 on each side, much branched and obviously anastomosing near the margin but eventually passing into the teeth where those are present, slightly impressed above and very prominent (including the reticulum) below; petioles very short (3 to $5 \mathrm{~mm}$. long), densely or sparsely fulvous-tomentose. Catkins? Fruit annual, rather large, solitary or paired on a peduncle 5 to $18 \mathrm{~mm}$. long and 5 to $7 \mathrm{~mm}$. thick; cups 3 to $4 \mathrm{~cm}$. broad, openly goblet-shaped or cup-shaped, the scales triangular-ovate to oblong and narrowly obtuse, densely short-pubescent, loosely appressed; acorns depressed-subglobose or elliptic, $2.5 \mathrm{~cm}$. long and $3 \mathrm{~cm}$. broad or (in the Panama material) $4 \mathrm{~cm}$. long and $2.5 \mathrm{~cm}$. broad, one-half or only one-fourth included. (See pls. 10 and 11.)

Range: Guatemala, Costa Rica, and upper Panama (1,400 to 1,900 m.); type from Guatemala (von Warscewicz 50a, without further locality).

Quercus oocarpa is the type species of the series Oocarpae which is not closely related to the other large-fruited series and is characterized by its oblanceolate, toothed, attenuately acute leaves with markedly short and inconspicuous petioles. The thin leaves, villous beneath, distinguish $Q$. oocarpa from $Q$. pilarius.

Specimens examined:

GUATEMALA.-Dept. Alta Verapaz: near Finca Sepacuite, April 10, 1902, Cook and Griggs 572 (US). Dept. BaJA Verafaz: Valley of Santa Rosa, June 5, 1904, Cook 220 (US). Dept. Guatemala: Volcan de Pacaya, between San Francisco Sales and base of the active cone, December 20, 1940, Standley 80624 (USNA). Dept. Chiquimula: Volcan Quezaltepeque, northeast of Quezaltepeque, November 8, 1939, Steyermark 31485 (F); Volean Ipala, near Amatillo, October 25, 1939, Steyermark 30525 (F); upper slopes of Montaña Tajuran, vicinity of El Barriol, October 28, 1939, Steyermark 30807 (F). 
HONDURAS.-Dept. Comayagda: summits near El Achote above Siguatepeque, July 28, 1936, Yuncker, Dawson, and Youse 6180 (DeP, F, Ill [type of Q. yunckeri], MBG, Mi).

COSTA RICA.-Cerro Jucosal, March 3, 1928, Stork 1129 (F). Prov. CARTAGO: near Finca Las Concavas, December 7-8, 1925, Standley 41459 (US); Dulce Nombre, February 27, 1924, Standley 35958 (US); El Muñeco, south of Navarro, February 8-9,1924, Standley 33869 (US); March 6-7, 1926, Standley and Torres 51147 (US); Standley and Torres 51270 (F, US); vicinity of Orosi, March 30, 1924, Standley 39798 (US). Prov. SAN Jose: Cerro de Piedra Blanca, above Escasu, January 31, 1924, Standley 32619 (F, US). Prov. Alajuela: near San Ramon, peaks of hills of Tremedal, April 10 and May 10, 1913, Tonduz 17693 (F, US [2]); vicinity of Fraijanes, February 12-13, 1926, Standley and Torres 47424 (F, US); Palmira, July 1, 1941, A. Smith 2878 (USNA).

PANAMA.-Prov. Chiriqui: valley of upper Rio Chiriqui Viejo, vicinity of Monte Lirio, June 27-July 13, 1935, Seibert 317 (MBG, NY); Distr. Boquete, Bajo Mono, April 3, 1938, Davidson 497 (F, MBG); Boquete to Finca Lerida, April 4, 1937, Allen 303 (MBG, USNA); Finca Lerida to Peña Blanca, July 9, 1940, Woodson and Schery 286 (USNA).

5. Quercus pilarius Trel., Mem. Nat. Acad. Sci. 20: 44 . pl. 19. 1924.

Quercus yousei Trel. in Yuncker, Field Mus. Bot. Ser. 17: 358. 1938.

Small or large tree, 4 to $25 \mathrm{~m}$. tall. Twigs slender (1 to $2 \mathrm{~mm}$.), fluted, from sparingly pilose and brown quickly glabrate and gray with a few scarcely prominent lenticels. Buds subglobose, about 3 $\mathrm{mm}$. long, glabrate or the scales ciliate; stipules caducous or persistent, 5 to $7 \mathrm{~mm}$. long, spatulate-ligulate, light brown and appressedsericeous or glabrous. Leaves evergreen, moderately thick and hard, 6 to 24 (usually about 15 ) $\mathrm{cm}$. long, 2.5 to 7 (usually about 4 ) $\mathrm{cm}$. broad, lanceolate or oblanceolate, attenuately acute (or the ultimate apex minutely obtuse), basally cordulate or cuneate, coarsely crenateserrate above the middle, the teeth abruptly directed forward, mucronate-tipped, margins minutely revolute or flat, both surfaces somewhat shining, appearing in juvenile form with the midrib and veins appressed-sericeous but quickly glabrate and at maturity entirely glabrous or the midrib slightly pubescent; veins about 12 to 15 on each side, very irregular and with occasional evanescent intermediates, much branched and obviously anastomosing but ultimately passing into the teeth where those are present, slightly raised above (including the reticulum) and quite prominent beneath; petioles very short (1 to 3 or rarely $4 \mathrm{~mm}$.), much thickened at the base, glabrate. Flowers and fruit? (See pls. 12 and 13.)

Range: Chiapas, Guatemala, Honduras, and Costa Rica (1,150 to 2,400 m.); the type from Tapachula, Chiapas, Mexico (Reeves 11).

Quercus pilarius is distinguished from $Q$. oocarpa, the only species to which it is at all closely related, by its slender glabrate twigs and its thick and firm leaves glabrous at maturity.

Specimens examined:

MEXICO-ChIAPAs: Copainala, August 1940, Martinez 390 (USNA).

GUATEMALA.-Chinkabal, September 1939, Lewis without number (F). Dept. San Marcos: Barranco Emenencia, above San Rafael Pie de la Cuesta, March 14-15, 1939, Standley 68686 (F) ; Finca El Porvenir, Volcan Tajumulco, March 12, 1940, Steyermark 37570 (F, USNA). Dept. Quezaltenango: Finca Pireneos, below Santa Maria de Jesus, March 11, 1939, Standley 68360 and 68374 (F); Rio Samala, near Santa Maria de Jesus, January 25, 1941, Standley 84631 and $84747^{\circ}$ (USNA). Dept. Suchitepequez: Volcan Zunil, near Finca Las Nubes, east of Pueblo Nuevo, February 2, 1940, Steyermark 35448 (F). DEPT. 
Alta Verapaz: mountains east of Tactic, on road to Tamahu, April 9, 1939 Standley 71290 (F, USNA). Dept. Escuintla: Finca Monterrey, south slope of Volcan de Fuego, February 5, 1939, Standley 64563 (F, USNA).

HONDURAS.-Dept. Comayagua: El Achote, hills above plains of Siguatepeque, August 3, 1936, Yuncker, Dawson, and Youse 6297 (DeP, F, MBG, Mi, NY, US [isotypes of $Q$. yousei]).

COSTA RICA.-Prov. Alajuela: cataracts of San Ramon, February 20, 1931, Brenes 13487 (F). Prov. San Jose: vicinity of Santa Maria de Dota, December 14-26, 1925, Standley 42425 and 42842 (F, US).

Series Corrugatae Trel., Mem. Nat. Acad. Sci. 20: 44.1924.

Series Cyclobalanoideae Trel., Mem. Nat. Acad. Sci. 20: 44.1924.

Large trees with rather coarse glabrate twigs; buds round-ovoid; stipules caducous; leaves moderate or large, deciduous or evergreen, oblanceolate or lanceolate, coarsely incurved-serrate, glabrate, evidently petiolate; fruit large, the scales much thickened basally, acorns ovoid to oblong, cotyledons unequal.

Range: Sierra Madre Oriental of Mexico to Costa Rica.

Includes: Q. corrugata Hook. (type) and one species in the Sierra Madre Oriental of Mexico.

This series is distinguished from the other large-fruited groups by its relatively long petioles and glabrous leaves with incurved or antrorse teeth.

6. Quercus corrugata Hook., Icones Plant. 5: pl. 403, 404. 1842.

Quercus excelsa Liebm., Overs. Danske Vidensk. Selsk. Forhandl. 1854: 174.1854.

Q. corrugata var. microcarpa Wenzig, Jahrb. K. Bot. Gart. Berlin 2: 192.1884.

Q. pilgeriana Seemen, Bul. Herb. Boissier, 2 ser., 4: 655. 1904.

Q. cyclobalanoides Trel., Proc. Amer. Philos. Soc. 54: 11. pl. 3. 1915.

Q. reevesii Trel., Mem. Nat. Acad. Sci. 20: 45. pl. 22. 1924.

Q. corrugata var. granulifera Trel., Mem. Nat. Acad. Sci. 20: 45. pl. 24. 1924.

Q. corrugata var. ipalensis Trel., Mem. Nat. Acad. Sci. 20: 45. 1924.

Small or large tree, 6 to $20 \mathrm{~m}$. tall. Twigs slender or coarse (often on the same branch), 1.5 to $5 \mathrm{~mm}$. thick, fluted, glabrous or from sparingly strigose soon glabrescent, brown but soon becoming gray with rather large pale lenticels. Buds about $3 \mathrm{~mm}$. long, round-ovoid, glabrous, grayish brown; the stipules caducous, about $10 \mathrm{~mm}$. long, ligulate, dorsally pubescent. Leaves deciduous, thick and rather hard, 5 to usually 15 or even $25 \mathrm{~cm}$. long, 2 to 5 or even $7 \mathrm{~cm}$. broad, lanceolate to oblanceolate or a broader form elliptic to obovate, acute to attenuately acuminate and the ultimate apex narrowly rounded or acute, basally cuneate to rounded, coarsely toothed with the teeth abruptly directed forward and mucronate-tipped, entire toward the base, margins minutely revolute or flat, both surfaces somewhat shining, glabrous, old leaves somewhat bullate-granular above or smooth; veins 12 to 14 or even 18 on each side, branching and more or less obviously anastomosing but ultimately passing into the teeth where those are present, minutely raised (including the reticulum) above, more prominent beneath; petioles 15 to $40 \mathrm{~mm}$. long or rarely 
shorter, glabrous or puberulent. Staminate catkins 5 to $6 \mathrm{~cm}$. long, sparsely villous, loosely flowered, the anthers much exserted. Pistillate catkins about $5 \mathrm{~mm}$. long, 1 - or 2 -flowered. Fruit annual, solitary on a peduncle 5 to $10 \mathrm{~mm}$. long, rather large; cups 3 to 4 or even $6 \mathrm{~cm}$. broad, shallowly cup-shaped or hemispheric (or discoid in some Mexican forms), very thick, the scales broadly ovate with narrowed apices, much thickened basally, appressed, closely tomentose; acorns subglobose or ovate to oblong, 3 to $5 \mathrm{~cm}$. in diameter, typically longitudinally corrugated but often smooth, dark brown, from sparsely villous glabrate, about one-half included. (See pls. 14 to 19.)

Range: Chiapas and southeastern Mexico to Guatemala, El Salvador, and Costa Rica (1,000 to 1,800 m.); type from Cerro del Tamber, Guatemala (Skinner 5).

Quercus corrugata is the type species (by inference) of Trelease's series Corrugatae to which it becomes necessary to add the Cyclobbalanoideae. Quercus pilgeriana can scarcely be held distinct from Q. corrugata since the only diagnostic character (length of petiole) is strongly developed throughout $Q$. corrugata. The puberulence of the petiole of $Q$. pilgeriana is not seen elsewhere, but the character can bear but little weight in specific distinction unless correlated with more reliable evidence. The bullate-granular condition of var. granulifera appears on almost all old leaves even though slightly younger leaves on the same branch are smooth. The elongate petioles of var. ipalensis also occur throughout the species. The short petioles and often discoid cups of $Q$. excelsa are not considered of specific significance. Short petioles appear sporadically in the species, and discoid cups seem to be the result of the gradual flattening of shallow cups upon ripening.

The reduction of $Q$. cyclobalanoides and $Q$. reevesii to synonymy under Q. corrugata is necessitated for lack of any characters on which they may be distinguished. The type collections of these two proposed species definitely show this identity in both fruiting and vegetative characters. The fruits (identical in the two) have the acorns nearly twice as long as broad and much exserted, a condition to be expected with complete maturity, and the cups are identical with those of Q. corrugata. The leares of Q. reevesii cannot be distinguished from those of $Q$. corrugata, whereas those of $Q$. cyclobalanoides are typical of the expanded condition that results from dense shading and otherwise do not differ.

Specimens examined:

MEXICO.-ChIAPas: Finca Irlanda, August 1913, Purpus 6998 (F, US [type of $Q$. cyclobalanoides], USNA [seed coll.]).

GUATEMALA.- Without data, Skinner 3 (NY). Dept. SAN MARcos: above Finca El Porvenir, south slope of Volcan Tajumulco, March 8, 1940, Steyermark 37243 (F, USNA); March 16, 1940, Steyermark 37990 (F). Dept. QuezalteNANGo: vicinity of Santa Maria de Jesus on Volean Santa Maria, January 8, 1940, Steyermark 33テ்65 (F); January 12, 1940, Steyermark 34230 (F, USNA); January 18, 1940, Steyermark 34368 and 34369 (F). Dept. Retalnulen: west of Volcan Santa Maria, about 20 miles from Retalhulen, February 1918, Reeves without number (Ill [type of Q. reevesii]); Finca Helvetia, May 2, 1937, Muenscher 12438 (F). Dept. Suchitepequez: Finca Moca, April 3, 1931, Bequaert 40 (AA, F, G); May 4, 1937, Muenscher 12453 (F). Dept. Alta Verapaz: near Finca Sepacuite, April 10, 1902, Cook and Griggs 569 and 571 (US). Dept. Chiquimula: Volcan de Ipala, around the lake, January 1907, Pittier 1869 (US [type of var. ipalensis]).

BRITISH HONDURAS.-Without further data, 1926, Stevenson 8939 (F [fragment]). 
EL SALVADOR-Cerro de Apaneca, 1928, Calderon 2428 (F, US).

HONDURAS.-Dept. Yoro: El Portillo Grande, July 1937, von Hagen 1011 $(\mathrm{F}, \mathrm{NY})$.

COSTA RICA.-Cuesta de Tarrazu, April 1893, Tonduz 78\%1 (US). Prov. Alajoela: Rio Ciruelas, March 1890, Pittier 2197 (US [isotype of Q. pilgeriana]); La Ventana, on south slope of Volcan de Poas, February 17-18, 1924, Standley 34561 (F, US); Llano Bonito, May 22, 1941, A. Smith 2742 (USNA). Prov. Heredia: Santa Barbara, June 1919, Lankester 241 (F). Prov. San Jose: vicinity of Santa Maria de Dota, December 14-26, 1925, Standley 41707 (US); Standley 42834 (F, US); December 26, 1925-January 3, 1926, Standley and Valerio 43403 (F, US). Prov. Puntarenas: Boruca, February 1891, Pittier without number (ÚS).

Series Lancifoliae Trel., Mem. Nat. Acad. Sci. 20: 47. 1924.

Series Boqueronaeae Trel., Mem. Nat. Acad. Sci. 20: 48. 1924.

Large trees with glabrate twigs; buds rounded; leaves deciduous, rather thick, medium-sized, oblong, subentire to coarsely toothed, petioles moderately long; fruit large, the deep cups with the scales immersed in thick tomentum with the apices protruding, the acorns narrowly elliptic-oblong or cylindric, cotyledons unequal.

Range: Chiapas and east-central Mexico to El Salvador and Panama.

Includes: Quercus boqueronae Trel., Q. panamandinaea C. H. Mull., and several Mexican species of which Q. lancifolia Schlecht. and Cham. ${ }^{6}$ is the type.

7. Quercus boqueronae Trel., Mem. Nat. Acad. Sci. 20:48. pl.33. 1924.

Apparently a large tree. Twigs 1.5 to $2 \mathrm{~mm}$. thick, fluted, glabrous, gray with a few inconspicuous light lenticels. Buds rounded, scarcely $2 \mathrm{~mm}$. in diameter, glabrous, brown, the stipules caducous or sometimes persistent about the terminal bud, about $5 \mathrm{~mm}$. long, subulateligulate. Leaves deciduous, rather thick and firm, about 5 to 8 or $10 \mathrm{~cm}$. long and 1.5 to $3.5 \mathrm{~cm}$. broad, lance-elliptic or oblong, acute or ultimately minutely rounded apically, cuneate or almost rounded at base, coarsely toothed above the middle or entire, the margins minutely revolute, upper surface shiny, the lower dull, both quite glabrous; veins about 10 or 12 on each side, irregular, much branched and obviously anastomosing but ultimately passing into the teeth where those are present, moderately raised on both surfaces; petioles 5 to $8 \mathrm{~mm}$. long, very dark especially toward the base, glabrous. Catkins? Fruit annual, solitary on glabrous peduncles 12 to $25 \mathrm{~mm}$. long and 2 to $3 \mathrm{~mm}$. thick; cups deeply cup-shaped, about 1.5 to $2 \mathrm{~cm}$. high and 2 to $2.5 \mathrm{~cm}$. broad, the margins often roughly fringed with projecting scales, the scales much thickened basally, rhombic in shape, only the upper ones with narrowed apices, densely fulvous-tomentose, the apices merely puberulent; acorns 3 to $4 \mathrm{~cm}$. long, about $2 \mathrm{~cm}$. broad, elliptic-oblong to cylindric, dark shiny brown, glabrous, about one-third to one-half included. (See pl. 20.)

Range: Mexico, in the mountains of Chiapas, and El Salvador.

Quercus boqueronae is not closely related to any other species in the area under consideration. It is rather a relative of the east Mexican

\footnotetext{
6 These authors are almost invariably cited as "Chamisso and Schlechtendal," which is the order in which their series "Plantes Exped. Romanzoffiana" (Linnaea, vols. 1-10) is signed, except when Chamisso is the sole author. However, the shorter concurrent series "Plantarum Mexicanarum (Schiede et Deppe collectarum)" (Linnaea 5: 72-174, 206-236, 554-625: 6: 22-64, 352-384, 385-430. 1830-1831) was signed "Schlechtendal and Chamisso," and species described therein should be cited with the authors' names in that order.
} 
Q. leiophylla A. DC., from which it is distinguished by its deciduous leaves with longer petioles. From the less closely related Q. panamandinaea it is readily separated by its smaller toothed leaves not acuminate and by its densely fulvous-tomentose cup scales.

Specimens examined:

MEXICO.-Chiapas: Cerro del Boqueron, September 1913, Purpus 6997 (F, US [isotypes]); Mt. Ovando, April 9-12, 1937, Matuda 1823 (AA, DeP, Mi); Matuda 1824 (AA, Mi, US, USNA).

EL SALVADOR.-Dept. AhUachapan: Cerro de Apaneca, 1928, Calderon 2429 (F [a mixed collection consisting mostly of Q. skinneri]).

\section{Quercus panamandinaea sp. nov.?}

Large tree to $25 \mathrm{~m}$. tall. Twigs 1 to scarcely $2 \mathrm{~mm}$. thick, fluted, from stellate-pubescent glabrate and brown with few rather inconspicuous light lenticels. Buds 2 to $2.5 \mathrm{~mm}$. long, ovoid, subacute, glabrous, straw-colored; stipules caducous. Leaves evergreen, thin but hard, 10 to $15 \mathrm{~cm}$. long, 4 to $6 \mathrm{~cm}$. broad, broadly lanceolate to oblanceolate, long-acuminate, the bases cuneate to rounded or apparently truncate and then minutely cuneate, entire or the margins slightly wavy but scarcely toothed, somewhat crisped, minutely revolute, both surfaces glabrous or sparsely stellate-pubescent at the base of the midrib above, dully shining; veins 12 to usually 15 or 18 on each side with evanescent intermediates, branching (often doubly) and anastomosing toward the margin, impressed above but slightly raised (as is the reticulum) within the grooves, quite prominent beneath, the reticulum less so; petioles about $4 \mathrm{~mm}$. long (excluding the cuneately decurrent lamina), 1.5 to $3 \mathrm{~mm}$. thick, glabrous or sparingly stellate-pubescent, dark reddish brown. Staminate catkins? Pistillate catkins up to $1.5 \mathrm{~cm}$. long, 2- or 3-flowered, the peduncle glabrous. Fruit annual, solitary, in twos, or in threes, peduncles about $1 \mathrm{~cm}$. long, glabrous; cups about $25 \mathrm{~mm}$. broad, $15 \mathrm{~mm}$. high, cup-shaped, the scales ovate to ovatelanceolate, basally thickened and densely gray-tomentose, the thin loose apices glabrous and reddish brown; acorns about $25 \mathrm{~mm}$. long, 16 to $18 \mathrm{~mm}$. broad, ovoid, glabrous and light brown, the cotyledons decidedly unequal with the radicle lateral or equal with the radicle apical. (See pls. 21 and 22.)

Range: Known only from upper Panama.

Quercus panamandinaea (named for Panama and Andinae, a series in Erythrobalanus which it superficially resembles quite closely) is a remarkable endemic species. It is here referred to the series Lancifoliae in part because of its leaf characters and its sometimes unequal cotyledons, but that disposition is not at all conclusive. The species is amply distinguished from all others by the nature of its cup scales and (from the other species in the Lancifoliae) by its large, shortpetioled, and long-acuminate leaves.

Specimens examined:

PANAMA.-Prov. Chiriqui: Casita Alta to Copete, July 10, 1940, Woodson and Schery 360 (MBG [type], USNA).

\footnotetext{
Quercus panamandinaea sp. nov.-Arbor grandis, ramuli 1-2 mm. crassi glabrati, gemlmae 2-2.5 mm longae ovoideae glabrae flavae, stipulae caducae, folia sempervirentia 10-15 cm. longa 4-6 $\mathrm{cm}$. lata oblanceolata vel late lanceolata longe acuminata glabra, venis utrinque 12-18 ramosis et anastomosantibus, petioli $4 \mathrm{~mm}$. longi, fructus annuus pedunculatus, cupula $25 \mathrm{~mm}$. lata $15 \mathrm{~mm}$. alta, squamae ad basin crassae tomentosae ad apicem chartaceae laxe appressae.
} 
Series Aáatae ser. nov. ${ }^{8}$

Large trees with markedly whitened strigose twigs; stipules usually persistent; leaves moderate, elliptic to oblanceolate, obtuse, narrowly rounded; veins usually impressed above and very prominent beneath, much branched and anastomosing, the midrib usually strigose beneath toward the base; petioles short; fruit moderate, cotyledons unequal.

Range: Guatemala to Costa Rica.

Includes: Q. aáata C. H. Mull. (type).

The series Aáatae is a relatively well marked entity distinguished from the other series by its pubescence, thin leaves, persistent stipules, short petioles, and whitened twigs. Although most of these characters appear also in other groups, in none of them is the combination encountered. The series seems to be a small-fruited analogue of the Oocarpae, but no closer relationship can be assigned to it.

\section{Quercus aáata sp. nov. ${ }^{9}$}

Large tree up to $22 \mathrm{~m}$. tall and with a trunk diameter of more than $2 \mathrm{~m}$. Twigs slender (1.5 to $2.5 \mathrm{~mm}$.), fluted, strigose and appressedstellate, becoming glabrous and gray or white with scarcely evident lenticels the second season. Buds round-ovoid to elliptic, 3 to $5 \mathrm{~mm}$. long, glabrous, straw-colored; stipules persistent, 6 to $10 \mathrm{~mm}$. long, ligulate and glabrous or subulate and strigose about the terminal bud. Leaves deciduous, thin but firm and rather hard, 6 to $16 \mathrm{~cm}$. long, 2 to $6 \mathrm{~cm}$. broad, elliptic or oblanceolate to oblong-obovate or rhombic, much narrowed toward the apex or only slightly so, acute but the tip finally narrowly rounded or rarely broadly rounded, basally attenuate and very narrowly cuneate to rounded, subentire to obscurely and coarsely toothed near the apex, the margins flat or minutely revolute, upper surface dark green, dull, glabrous except for the midrib which is strigose toward the base, lower surface shiny or dull, glabrous except the strigose midrib or fulvous-tomentose along the midrib; veins about 10 to 15 on each side, rather regularly parallel and lacking intermediates or irregular and with intermediates, much branched and obviously anastomosing near the margin, slightly raised (the principal ones within shallow grooves) on the upper surface, quite prominent (including the reticulum) below; petioles 2 to 7 (usually about 4) mm. long, strigose. Catkins? Fruit annual, solitary or paired, pedunculate; cups about $2.5 \mathrm{~cm}$. broad, hemispheric or shallowly cup-shaped, the scales ovate with abruptly narrowed oblong tips loosely appressed, much thickened and velutinous at the bases, the apices strigose and brown; acorns ovoid, 2 to $2.5 \mathrm{~cm}$. long, scarcely $2 \mathrm{~cm}$. broad, glabrate, about one-third to one-half included. (See pls. 23 to 26 .)

Range: Guatemala, Honduras, and Costa Rica (1,500 to 2,400 m.).

Quercus aáata (from the Greek, aaatos, invincible) is the only species known in the series Aáatae. It could scarcely be confused with any other species in our range, except in its obtuse-leafed form in Costa

${ }^{8}$ Series Aáa tae ser. nov.-Arbores grandes, ramuli albi strigosi, stipulae persistentes, folia mediocria elliptica vel oblanceolata obtusa ad basin anguste rotundata, venis supra impressis subtus prominentibus ramosis et anastomosantibus, costa subtus ad basin strigosa, petioli breves, fructus annuus mediocris, cotyledones inaequales.

Quercus aáata sp. nov.-Arbor grandis, ramuli 1.5-2.5 mm. crassi glabrati, gemmae 3-5 mm. longae glabrae, folia decidua chartacea $6-16 \mathrm{~cm}$. longa $2-6 \mathrm{~cm}$. lata elliptica vel oblanceolata vel obovata ad apicem angustata ad basin attenuato-cuneata vel angusto-rotundata integra vel ad apicem dentata glabra costis strigosis vel fulvo-tomentosis exceptis, venis utrinque 10-15 ramosis et anastomosantibus, petioli $2-7 \mathrm{~mm}$. iongi, fructus annuus, cupula $2.5 \mathrm{~cm}$. lata hemispherica vel minus profunda, glans $2-2.5 \mathrm{~cm}$. longa ovoidea. 
Rica (represented by Standley and Valerio 50651, Smith 2756 and 2879) which approaches Q. pacayana in thickness of lamina, rounded leaf bases, impressed veins, etc. It is very likely that mature fruiting material of all the forms involved will prove this Costa Rican form to be a distinct species, but there is at present no justification for the segregation.

Specimens examined:

GUATEMALA.-Dept. Guatemala: Volcan de Pacaya, above Las Calderas, November 30, 1938, Standley 58466 (F [2] [type as sheet no. 982534], USNA). Dept. JalapA: Volcan Jumay, north of Jalapa, December 1, 1939, Steyermark 32379 (F, USNA).

HONDURAS.-Dept. Tegucigalpa: La Aurora trail, Rosario, San Juancito, April 2, 1932, Edwards 18 (AA, F).

COSTA RICA.- Prov. Alajuela: Palmira, June 11, 1941, A. Smith 2756 (USNA); July 1, 1941, A. Smith 2879 (USNA). Prov. Heredia: Cerros de Zurqui, northeast of San Isidro, March 3, 1926, Standley and Valerio 50546 and 50651 (F, US) ; Cerro de las Caricias, north of San Isidro, March 11, 1926, Standley and Valerio 52178 and 5219/4 (F, US); Vara Blanca de Sarapiqui, north slope of Central Cordillera, between Poas and Barba Volcanoes, February 1938, Skutch 3584 (US). Prov. SaN Jose: near Finca La Cima, above Los Lotes, north of El Copey, December 21-22, 1925, Standley 42629 (F,US). Prov. Cartago: Cerro de la Carpintera, February 1924, Standley 34395 (US); "Highest Carpintera," April 3, 1928, Stork 1365 (F).

Series Polymorphae Trel., Mem. Nat. Acad. Sci. 20: 49. 1924.

Small or large trees with glabrate twigs; buds ovoid; leaves deciduous, medium-sized, ovate-lanceolate or oblong, entire or few-toothed, evidently petiolate, glabrate above, waxy-glaucous beneath; fruit medium-sized, the scales markedly thickened basally.

Range: Sierra Madre Oriental of Mexico to Guatemala.

Includes: Q. polymorpha Schlecht. and Cham. (type) and one doubtful species in Mexico.

10. Quercus polymorpha Schlecht. and Cham., Linnaea 5: 78. 1830.

Quercus petiolaris Benth., Pl. Hartw. 55, 348. 1840.

Q. varians Mart. and Gal., Bul. Acad. Brux. 10: 214.1843.

Q. guatimalensis A. DC. in DC. Prodr. $16^{2}: 78.1864$.

Q. turbinata Liebm., Overs. Danske Vidensk. Selsk. Forhandl. 1854: 186. 1854. Not Q. turbinata Blume, Bijdr. Fl. Ned. Ind. 523. 1825 .

Medium-sized tree. Twigs 2 to $3 \mathrm{~mm}$. thick, obscurely fluted, reddish brown, from loosely buff tomentose soon glabrate, with numerous pale lenticels. Buds about 3 to $5 \mathrm{~mm}$. long, ovoid or lanceovoid, acute, reddish brown, glabrate or rather persistently hairy, the subulate pubescent stipules persistent only about the terminal bud. Leaves deciduous, rather thick, about 5 to usually 10 or even $15 \mathrm{~cm}$. long, 3 to 4 or $6(8) \mathrm{cm}$. broad, oblong-elliptic or ovate to lanceolate or obovate, broadly or narrowly rounded and often emarginate at apex, rarely acuminate but the tip finally rounded, cordate or rounded at base, entire or crenately coarsely mucronate-toothed above the middle, margins minutely cartilaginous-revolute, upper surface dull or shiny, glabrate, lower surface opaque or somewhat waxy-glaucous, rather persistently buff-floccose or glabrate; veins about 10 to 12 or 14 on each side, much branched and anastomosing near the margin, impressed above, very prominent (including the reticulum) beneath; petioles 6 to usually 15 to $25 \mathrm{~mm}$. long, glabrate, reddish brown. Staminate cat- 
kins 6 to $8 \mathrm{~cm}$. long, floccose, rather densely flowered, the glabrous anthers much exserted. Pistillate catkins 5 to $10 \mathrm{~mm}$. long, 1 - or 2-flowered. Fruit annual, solitary or paired on a peduncle 5 to 30 $\mathrm{mm}$. long; cups about $15 \mathrm{~mm}$. in diameter, hemispheric, the scales prominently thickened basally, acute and appressed apically, canescent; acorns 20 or $25 \mathrm{~mm}$. long, about $12 \mathrm{~mm}$. in diameter, about onehalf included. (See pls. 27 to 29.)

Range: The Sierra Madre Oriental region of Mexico from Nuevo Leon to southern Veracruz, reappearing in Guatemala; the types from Jalapa, Veracruz, Mexico (Schiede 20 and 501B).

Quercus polymorpha is one of the most widely distributed of the Latin American species. Its variations in leaf form in no manner affect the constancy of its fundamental characters of fruit, leaf texture, veining, etc. The species is not related to any other in our range and could not readily be confused.

It has not been possible to examine the type of $Q$. guatimalensis. However, the very intensive collections of Standley and Steyermark have turned up nothing that fits the description of Q. guatimalensis except undoubted specimens of $Q$. polymorpha, and these fit Liebmann's, de Candolle's, and Trelease's descriptions exceedingly well so far as vegetative characters are concerned. It is significant that both the former descriptions called the leaves "mucronate." It is doubtful that any species of Erythrobalanus has teeth that could be so described, but those of $Q$. polymorpha, as it occurs in Guatemala, are definitely so. Trelease's illustration $(p l .300)$ of the type of Q. guatimalensis rather clearly indicates the vegetative parts to be conspecific with $Q$. polymorpha. The fruit, both as described and as illustrated, is not of this species. Trelease figures it as detached, and his doubt concerning maturation as well as his failure to mention its attachment further indicates its detachment. Neither Liebmann nor de Candolle mentioned this item. The fruit closely resembles that of Q. sapotaefolia, for it is clearly of an Erythrobalanus species, and no other species of either subgenus has fruit of that small size and appearance.

The fruit of $Q$. correpta, as illustrated by Trelease on the same plate, is of the same type and likewise detached. Apparently von Warscewicz mixed these fallen fruits through several of his sterile collections by accident.

Specimens examined:

MEXICO-Chiapas: Santa Rosa, near Escuintla, June 20, 1941, Matuda 4234 (USNA).

GUATEMALA.-Dept. Huendetenango: Uaxac Canal, August 6, 1896. $C$. and E. Seler $3067(\mathrm{G})$; west of Aguacatan toward Huehuetenango, December 27, 1940, Standley 81244 (USNA). Dept. JALAPA: along Rio Jalapa, between Jalapa and San Pedro Pinula, December 9, 1939, Steyermark 32939 (F, USNA); Montaña Durazno, 2 miles east of San Pedro Pinula, December 10, 1939, Steyermark 32966 (F, USNA); Steyermark 32973 (F [2], USNA). Dept. Chiquimula: along Rio Taco, between Chiquimula and Montaña Barriol, October 26, 1939, Steyermark 30625 (F).

Series Pacayanae ser. nov. ${ }^{10}$

Large trees, the twigs glabrous, buds round-ovoid, the stipules caducous or persistent; leaves deciduous(?), thick, rather small,

${ }^{10}$ Series Pacayanae ser. nov.-Arbores grandes, ramuli mediocres glabri, gemmae rotundo-ovoideae, folia decidua mediocria coriacea elliptica vel anguste obovata glabrata costa excepta, fructus annuus parvus pedunculatus.

$323472^{\circ}-42-3$ 
ovate to narrowly obovate, broadly rounded, glabrate except for the usually strigose and fulvous-tomentose midrib; veins few, branching and anastomosing; petioles short or moderately long; fruit small, pedunculate.

Range: Guatemala to Panama.

Includes: Q. pacayana (type) and Q. copeyensis.

The series Pacayanae is a rather remarkable endemic group, which, in its small glabrate leaves with few veins, is quite clearly distinguished from other rain-forest species. Its strigose midrib, usually somewhat tomentose beneath, suggests a relationship to the series Aáatae with which it is coincident in range, but its thick leaves, not markedly narrowed basally, deny such a relationship.

\section{Quercus pacayana sp. nov. ${ }^{11}$}

Large tree. Twigs 1.5 to $3 \mathrm{~mm}$. thick, glabrate, tan with numerous prominent pale lenticels, becoming quite gray. Buds round-ovoid, about $3 \mathrm{~mm}$. long, glabrous, light brown, the stipules about $4 \mathrm{~mm}$. long, subulate, caducous or sometimes persistent for a while. Leaves deciduous, about 4 to $8 \mathrm{~cm}$. long, 2 to $3.5 \mathrm{~cm}$. broad, rather thick, drying yellow, elliptic to usually narrowly obovate, broadly rounded, cordulate to usually rounded at base, subentire or crenately lowtoothed especially above the middle, margins minutely revolute, upper surface dull, glabrous or the midrib sparingly strigose, lower surface glabrous except the strigose and fulvous-tomentose midrib; veins about 10 or 12 on each side, much branched and obviously anastomosing near the margin, somewhat impressed above, very prominent (including the reticulum) beneath; petioles 4 to 12 (usually about 6) mm. long, glabrate, dark reddish brown. Catkins and fruit not seen, but the fruit probably small and pedunculate. (See pl. 30.)

Range: Volcan de Pacaya, Guatemala (1,800 to 2,400 m.).

This species and the following comprise the series Pacayanae whose relationships (or lack of them) are discussed above. Q. pacayana is closely related to $Q$. copeyensis from which it is distinguished by its very prominent reticulation and decidedly revolute leaf margins.

Specimens examined:

GUATEMALA.-Dept. Guatemala: Volcan de Pacaya, above Las Calderas, November 30, 1938, Standley 5846\% (F [2] [type as sheet no. 989364], USNA); Standley $58474(\mathrm{~F})$.

\section{Quercus copeyensis nom. nov. ${ }^{12}$}

Quercus costaricensis f. kuntzei Trel., Mem. Nat. Acad. Sci. 20: 146. pl. 283. 1924 (pro parte - as to type only).

Large tree to $15 \mathrm{~m}$. in height or taller. Twigs moderate (2 to 3 $\mathrm{mm}$.), somewhat fluted, strikingly yellowish-white, glabrous. Buds round-ovoid, about $3 \mathrm{~mm}$. long, glabrous, brown, the stipules persistent for a short time, about $7 \mathrm{~mm}$. long, ligulate, glabrous. Leaves

\footnotetext{
11 Quercus pacayana sp. nov.-Arbor grandis, ramuli 1.5-3 mm. crassi glabrati, gemmae $3 \mathrm{~mm}$. longae rotundo-ovoideae glabrae, folia decidua $4-8 \mathrm{~cm}$. longa $2-3.5 \mathrm{~cm}$. lata coriacea elliptica vel anguste obovata apice rotundata basi cordulata vel rotundata subintegra vel crenata glabrata, costa strigosa vel fulvo-tomentosa excepta, venis utrinque 10-12 subtus prominentibus, petioli 4-12 mm. longi glabrati.

12 Quercus copeyensis nme rotundo-ovoideae glabrae, folia decidua coriacea $4-8 \mathrm{~cm}$. longa $2.5-4 \mathrm{~cm}$. lata ovata vel obovata apice rotundata vel obtusa basi subcuneata vel cordulata integra glabra, costa subtus ad basim excepta, venis utrinque 6-7, petioli 4-7 mm. longi glabri, fructus annuus pedunculatus, cupula 10-12 mm. lata.
} 
deciduous, thick and very firm, 4 to 6 or rarely $8 \mathrm{~cm}$. long, 2.5 to $4 \mathrm{~cm}$. broad, ovate to obovate or broadly elliptic, the apex broadly rounded or merely obtuse, base subcuneate to cordulate but usually rounded, entire, the margins minutely revolute or flat, upper surface shiny, glabrous, lower surface dull, glabrous except occasional fulvous-stellate tomentum along the midrib toward the base; veins 6 or 7 or rarely 9 on each side, very irregular, much branched and obviously anastomosing, very slightly raised above with the reticulum not evident, more prominent beneath, the reticulum somewhat raised or not, petioles 4 to $7 \mathrm{~mm}$. long, dark brown, glabrous. Staminate catkins 3 or $4 \mathrm{~cm}$. long, the rachis sparsely pubescent or glabrous, loosely flowered or rather densely so toward the apex, the anthers little exserted. Pistillate catkins 2 or $3 \mathrm{~cm}$. long, several-flowered toward the apex, the styles short, stigmas abruptly dilated if at all. Fruit annual, several distally grouped on a glabrous peduncle about $3 \mathrm{~cm}$. long and $2 \mathrm{~mm}$. thick; cups about 10 or $12 \mathrm{~mm}$. broad, cup-shaped, the scales narrowly ovate, apically narrowed but obtuse, somewhat thickened basally, the thin apices closely appressed, gray-puberulent only at the base, otherwise glabrous and reddish brown; acorns (immature) about 1 $\mathrm{cm}$. in diameter, round, one-half included. (See pls. 31 and 32.)

Range: Mountains of central Costa Rica and of upper Panama $(2,100$ to $4,000 \mathrm{~m}$.).

Quercus copeyensis is most closely related to $Q$. pacayana from which its few irregular and usually inconspicuous veins and nearly flat leaf margins distinguish it. The form kuntzei referred by Trelease to $Q$. costaricensis, a species of Erythrobalanus, is clearly a member of Lepidobalanus. The type of the form is obviously conspecific with the other specimens of $Q$. copeyensis, but an isotype in the National Museum is clearly Q. costaricensis.

Specimens examined:

COSTA RICA.-Prov. SAN Jose: near Finca La Cima above Los Lotes, north of El Copey, December 21-22, 1925, Standley 42573 and 42583 (F, US); Cerro de las Vueltas, December 29, 1925-January 1, 1926, Standley and Valerio 43982 (F. US). Prov. Cartago: Volcan Irazu, June 24, 1874, Kuntze 2282 (NY [type as of $Q$. costaricensis f. kuntzei]).

PANAMA.-Prov. Chiriqui: Volcan Chiriqui, between Potrero Muleto and the summit, July 13-15, 1940, Woodson and Schery 383 (USNA [from which the fruit is described]).

Series Tuberculatae Trel., Mem. Nat. Acad. Sci. 20: 56. 1924.

Series Aurantiacae Trel., Mem. Nat. Acad. Sci. 20: 57. 1924. Series Segovienses Trel., Mem. Nat. Acad. Sci. 20: 58. 1924.

Medium-sized trees with slender or coarse glabrate twigs and prominent pale lenticels; buds round-ovoid or acute, the stipules persistent about the terminal bud; leaves medium-sized or large, elliptic to obovate, usually crenate, glabrous or stellate-pubescent beneath; petioles short; fruit annual, rather small, usually short-stalked, the cup scales keeled, puberulent.

Range: Sierra Madre of both eastern and western Mexico to Honduras and Nicaragua.

Includes: Q. segoviensis Liebm. and three or four species (including Q. tuberculata Liebm., the type) in Mexico. 
13. Quercus segoviensis Liebm., Overs. Danske Vidensk. Selsk. Forhandl. 1854: 186.1854.

Small tree. Twigs 1.5 to $5 \mathrm{~mm}$. thick, fluted, from stellate-tomentose becoming glabrate and reddish brown with numerous quite prominent pale lenticels. Buds 4 or $5 \mathrm{~mm}$. long, ovate to narrowly conic, acute, reddish brown, glabrate or somewhat persistently pubescent about the apex; the stipules about 4 or $5 \mathrm{~mm}$. long, subulate, dorsally strigose, persistent only about the terminal bud. Leaves deciduous, drying yellowish brown, about 8 to 12 or $15 \mathrm{~cm}$. long, 4 to 6 or even $9 \mathrm{~cm}$. broad, broadly obovate to suboblanceolate, broadly rounded at apex, usually markedly narrowed toward the base and strongly cordate or rarely cuneate, erosely crenate and submucronate or the base entire, margins revolute, upper surface dull, glabrate, lower surface from stellate-velvety nearly glabrate or somewhat persistently pubescent, the lamina low-bullate-granular; veins 8 to 10 or 11 on each side, branching but not evidently anastomosing, eventually passing into the teeth, not forming evident mucrones but these aborted and discolored as though frosted, principal veins raised above, quite prominent (including the reticulum) beneath; petioles 3 to $7 \mathrm{~mm}$. long, 2 to $5 \mathrm{~mm}$. thick, reddish, glabrate. Catkins and fruit? (See pls. 33 and 34.)

Range: Guatemala, Honduras, and Nicaragua (1,000 to 2,500 m.); the type from Segovia, Nicaragua (Oersted 3559).

Although Q. segoviensis is the only member of the series Tuberculatae in Central America, it is easily confused with certain species of other series to which it is scarcely related. Its characteristic obovate, cordate, erosely crenate leaves with raised veins and blades drying a striking yellowish brown separate it from $Q$. peduncularis and $Q$. pilicaulis, some forms of which it superficially resembles.

Specimens examined:

GUATEMALA.--Dept. Huenuetenango: Sierra de los Cuchumatanes, above Chiantla, February 19, 1939, Standley 65653 (F, USNA). Dept. San Marcos: Puente de Nahuatl-aa, near San Marcos, February 22, 1939, Standley 66205 (F). Dept. Guatemala: without further data, 1938-1939, Aguilar 321 (F). Dept. $\mathrm{Z}_{\mathrm{ACAPA}}$ : Sierra de las Minas, above Rio Hondo, October 11, 1939, Steyermark $29563(\mathrm{~F})$.

HONDURAS.-Dept. Comayagua: vicinity of Siguatepeque, February 14-27, 1928, Standley 55930 (AA, F, US).

Series Pedunculares Trel., Mem. Nat. Acad. Sci. 20: 67. 1924.

Medium-sized trees with tomentose, villous, or glabrate twigs; leaves evergreen, medium-sized, oblong-elliptic to obovate, crenate to coarsely serrate or entire, glabrate above, rather persistently loosetomentose or densely short-velvety or glabrate, short petiolate; fruit medium-sized, usually long-pedunculate, the scales short-tomentose.

Range: Sierra Madre Occidental of Mexico to Nicaragua.

Includes: Q. peduncularis Nee (type) and Q. purulhana Trel.

14. Quercus peduncularis Nee, Anal. Cienc. Nat. 3: 270. 1801.

Quercus callosa Benth., Pl. Hartw. 91. 1842.

Q. arachnoidea Trel., Mem. Nat. Acad. Sci. 20: 59. pl. 55.1924.

Q. barbeyana Trel., Mem. Nat. Acad. Sci. 20: 67. pl. 76.1924.

Q. barbanthera Trel., Mem. Nat. Acad. Sci. 20: 68. pl. 81. 1924.

Q. peduncularis subsp. callosa A. Camus, Monogr. Genre Quercus 2: 599. pl. 196, f. 22-28. 1939.

Q. aguana Trel. in Yuncker, Field Mus. Bot. Ser. 9: 281. 1940. 
Shrub to large tree, 2 to $18 \mathrm{~m}$. tall and up to $0.75 \mathrm{~m}$. in trunk diameter. Twigs various (1.5 to $5 \mathrm{~mm}$. in diameter), fluted or subterete, brown with numerous conspicuous pale lenticels, glabrous or at first usually densely stellate-tomentose and glabrate or persistently pubescent until the second year. Buds 2 to 4 or $5 \mathrm{~mm}$. long, ovoid to lanceolate, obtuse or acute, at first sparsely tomentose, glabrate and reddish brown; the stipules caducous or persistent for a short time, 5 to $7 \mathrm{~mm}$. long, subulate to narrowly ligulate, dorsally pubescent. Leaves subevergreen, thick and leathery, 6 to 16 (usually about 12 ) $\mathrm{cm}$. long, 3 to 10 (usually about 7 ) $\mathrm{cm}$. broad, obovate to occasionally oblanceolate or elliptic, broadly rounded to merely obtuse or occasionally abruptly acute at apex, the strongly narrowed bases markedly cordate or rarely rounded or even cuneate, undulately low-toothed or acutely serrate, only the extreme bases subentire, margins obviously revolute, upper surface from sparsely stellate-tomentose soon glabrate or persistently pubescent along the midrib, somewhat shining, lower surface at first either densely or sparsely tomentose, persistently pubescent or glabrescent, dull when denuded, the surface flat-bullate, either green or waxy-glaucous; veins about 10 to 12 on each side, branching and more or less obviously anastomosing near the margin but ultimately passing into teeth where these are present, impressed above, quite prominent beneath (including the reticulum), the thicker blades being more impressed-veiny and prominently reticulate; petioles 3 to $5 \mathrm{~mm}$. long, dark reddish brown, stellate-pubescent or glabrate. Staminate catkins 4 to 6 or $7 \mathrm{~cm}$. long, at length loosely flowered on the yellow-villous rachis, the glabrous anthers moderately exserted. Pistillate catkins 1 to $5 \mathrm{~cm}$. long, 2 to 4 flowers scattered toward the end of the yellowvillous peduncle. Fruit annual, solitary or several, subsessile to usually pedunculate; cups 15 to $18 \mathrm{~mm}$. broad, shallowly saucershaped to usually hemispheric, the scales ovate to lanceolate, moderately or markedly thickened basally, yellowish-pubescent or canescent, the thin apices appressed, narrowly rounded, glabrate; acorns about $15 \mathrm{~mm}$. long and $12 \mathrm{~mm}$. broad, ovoid, from densely pubescent becoming glabrate except the apical region, light brown or very dark brown, one-third or only one-fourth included. (See pls. 35 to 37.)

Range: Southern Mexico to El Salvador, very common in Guatemala; the type from between Mexico and Acapulco $(\mathrm{Nee})$.

Quercus peduncularis is an extremely variable and widespread species. One could as readily distinguish two dozen "species" as the five here listed as synonyms if all the local forms were taken into consideration.

Specimens examined:

MEXICO.-Chiapas: Monserrate, 1925, Purpus 91 (US); Siltepec, August 9, 1937, Matuda 1607 (Mi, USNA); Comitan, Hartweg 564 (NY [2]); May 1939, Martinez 373 (USNA); Las Casas, July 1940, Martinez 385 (USNA); Copainala, March 1939, Martinez 388 (USNA); Saxchanel, Sierra Madre, July 1, 1941, Matuda 4303 (USNA).

GUATEMALA.-Without further data, Hartweg 616 (NY [isotype of $Q$. callosa]). Dept. Huenuetenango: Uaxac Canal, August 23, 1896, Seler 2668 (G); Sierra de los Cuchumatanes, above Chiantla, February 19, 1939, Standley 65652 (F); Rio Pucal, $14 \mathrm{~km}$. south of Huehuetenango, January 4, 1941, Standley 82309 (USNA); 13-14 km. east of Huehuetenango toward Aguacatan, January 2, 1941, Standley 82010 (USNA); $15 \mathrm{~km}$. east of Huehuetenango toward Aguacatan, January 2, 1941, Standley 81934 and 81947 (USNA); west of Aguacatan toward Huehuetenango, December 27, 1940, Standley 81243 (USNA); Rio Pucal, February 20, 1939, Standley 65823 (F. USNA). Dept. San Marcos: 
Puente de Nahuatl-aa, near San Marcos, February 22, 1939, Standley 66203 (F, USNA); northwest slopes of Volcan Tajumulco, near Tajumulco, February 28, 1940, Steyermark 36918 (F). Dept. Quezaltenango: mountains above Ostuncalco, February 22, 1939, Standley 66397 (F, USNA); Volcan Santa Maria, above Santa Maria de Jesus and Los Mojadas, January 12, 1940, Steyermark 33963 and 34033 (F, USNA). Dept. Solola: southeast of San Jorge, August 12, 1936, Hatch and Wilson 307 (F). DePt. Quiche: between Quiche and San Pedro Jacopilas, January 12, 1939, Standley 62450 and 62451 (F); Standley 62457 (F, USNA). Dept. Chimaltenango: Garrucha, March 1892, Heyde and Lux 3152 (NY, US); between Chimaltenango and San Martin Jilotepeque, November 25, 1938, Standley 57967 (F, USNA); December 22, 1940, Standley 80864 and 80955 (USNA); near Rio Pixcayo, between Chimaltenango and San Martin Jilotepeque, February 3, 1939, Standley 64363 and 64485 (F); Standley 64371 and 64461 (F, USNA); Barranco de la Sierra, southeast of Patzum, December 31, 1938, Standley 61542 (F, USNA). Dept. Escuintla: above Palin, December 16, 1938, Standley 60102 (F, USNA). Dept. BaJa Verapaz: Rabinal, May 9, 1906, Cook 13 (US); "opposite El Rancho," Sierra de las Minas, January 6, 1906, Kellerman 5658 (US); January 1, 1908, Kellerman 7082 (F, XY); January 5, 1908 Kellerman 8043 (NY); hills north of Santa Rosa, Narch 30, 1939, Standley 69705 (F, USNA); Standley 69747 (F). Dept. Guatemala: Barrancas about Guatemala, July 1860, Hayes without number (G [2]); near Guatemala, July 1921, Tonduz 739 (NY, US [2]); edge of barranca, Parque Minerva, Guatemala, March 21, 1915, Trelease 50 (I11): Eureka, near Guatemala, April 2, 1915, Trelease 51 (III [3]) ; between Chiquin and Trapiche Grande, April 19, 1905, Pittier 130 (US); between Fiscal and Guatemala, June 7, 1909, Deam 6281 (Mi, US) ; Finca Bretana, between Guatemala and Fiscal, December 12, 1938, Standley 59742 (F, USNA); barraneo south of San Raimundo, January 18, 1939, Standley 62862 (F, USNA); hills between Guatemala and San Raimundo, January 18, 1939, Standley 62946, 63000, and 63002 (F, USNA). Dept. SaCATEPeQUez: between Mixco and Antigua, April 16, 1915, Trelease 48 and 49 (Ill); near Antigua, November 1938February 1939, Standley 61761 (F); Standley 63854 (F, USNA). Dept. Santa Rosa: Volcan Tecuamburro, north of Chiquimulilla, trail to summit, December 20, 1939, Steyermark 33159 (F). Dept. ZACAPA: Sierra de las Minas above Rio Hondo, October 11, 1939, Steyermark 29573 (F, USNA). DEPT. JALAPA: vicinity of Jalapa, November 7-18, 1940, Standley 76523 and 76732 (USNA); between Jalapa and Volcan Jumay, November 30, 1939, Steyermark 32316 (F); between Jalapa and San Pedro Pinula, December 9, 1939, Steyermark 32943 (F, USNA). Dept. Chiquimula: Rio Taco, between La Laguna and Chiquimula, October 27, 1939, Steyermark 30730 (USNA); Cerro Tixixi, north of Jocotan, November 10, 1939, Steyermark 31551 (F). DEPT. JUTIAPA: north of Jutiapa toward Plan de Urrutia, October 28, 1940, Standley 75589 (USNA).

EL SALVADOR.-Dept. Chalatenango: El Jute, 1928, Calderon 2446 (F, NY, US).

\section{4a. Quercus peduncularis var. sublanosa (Trel.) comb. nov.}

Quercus matagalpana Trel., Mem. Nat. Acad. Sci. 20: 58. pl. 54. 1924

Q. achoteana Trel. in Yuncker, Field Mus. Bot. Ser. 17: 356. 1938. Q. achoteana var. sublanosa Trel. in Yuncker, Field Mus. Bot. Ser. 17: 356.1938.

Small or large tree. Twigs variable (1.5 to 4 but usually about 2.5 $\mathrm{mm}$. thick), fluted, glabrous or from rusty-tomentose glabrate and brown with usually prominent pale lenticels. Buds about 3 to $4 \mathrm{~mm}$. long, ovoid or narrower, glabrate, the stipules persistent or caducous, about 5 to $8 \mathrm{~mm}$. long, ligulate or subulate, dorsally strigose. Leaves deciduous, thin, 10 to 18 or rarely only $6 \mathrm{~cm}$. long, 5 to 10 or rarely only $3 \mathrm{~cm}$. broad, obovate, the apex broadly rounded or rather abruptly acuminate, the much-narrowed base rounded or cordate, regularly undulate-toothed or serrate with the teeth mucronate-tipped, margins flat or minutely revolute, upper surface dully shining, glabrate or the base of the midrib puberulent, lower surface dull, glabrate or per- 
sistently stellate-puberulent or villous, the surface flat-bullate; veins about 12 to 16 on each side, rather regularly spaced and parallel, obscurely branching and anastomising, passing into the teeth, somewhat impressed above, very prominent (including the reticulum) beneath; petioles 3 to $7 \mathrm{~mm}$. long, glabrate or persistently tomentose. Staminate catkins? Pistillate catkins 1 to $7 \mathrm{~cm}$. long, 2- to 4-flowered distally on the tomentose or glabrate peduncle. Fruit annual, usually evidently peduncled; cups about $18 \mathrm{~mm}$. in diameter, hemispheric, the scales lanceolate, basally thickened, puberulent or tomentose; acorns ovoid, about $18 \mathrm{~mm}$. long, glabrous, one-third or one-half included. (See pls. 38 and 39.)

Range: Guatemala, Honduras, El Salvador, and Nicaragua.

The variety sublanosa is very difficult to distinguish adequately from the Central American representatives of the typical form. The inconstancy of its characters and the great number of intermediate specimens would make it very desirable to combine the two. Yet the typically thin expanded leaves of the variety sublanosa with regularly toothed margins, sparingly pubescent under surface, and many regular veins are hard to reconcile with the very thick subentire and densely tomentose leaves of typical Q. peduncularis. It is significant that the latter form is concentrated in southern Mexico and Guatemala, whereas the typical form of the variety sublanosa is most common in Honduras and to the south. The greater number of intermediates are encountered in Guatemala. This might indicate one of the often publicized "hybrid swarms" that have never conclusively been demonstrated to occur in Quercus.

The leaf form of the variety sublanosa is also very confusing in distinguishing it from Q. purulhana. Only the characteristic short dense pubescence of the lower leaf surface in the latter species can be depended upon to make the distinction.

\section{Specimens examined:}

BRITISH HONDURAS.-El Cayo District: Mountain Pine Ridge, February 22, 1931, Bartlett 11656 (NY); San Agustin, July-August 1936, Lundell 6626 (F, Mi, NY [2], US); Lundell 6729 (F, Mi, NY, US, USNA).

GUATEMALA.-DEPT. Huenuetenango: near Chalchitan, January 14, 1939 , Standley 62577 (F, USNA); mountains southwest of Malacatancito, January 14, 1939, Standley 62623 (F, USNA). Dept. Baja Verapaz: between Salama and Rabinal, May 31, 1904, Cook and Doyle 280 (US [2]); Cook and Doyle 286 (US). Dept. SACATEPEQUez: Cerro de la Cruz, above Antigua, January 22, 1939, Standley 63322 (F, USNA); Standley 63331 and 63332 (F). Dept. JALAPA: Volcan Jumay, north of Jalapa, December 1, 1939, Steyermark 32423 (F, USNA); Cerro Alcaba, east of Jalapa, December 2, 1939, Steyermark 32608 (F, USNA). Dept. Jutiapa: Los Llanitos, near San Jose Ácatempa, December 21, 1938, Standley 60581 and $60588(\mathrm{~F})$.

EL SAlvaDOR.-Dept. Chalatenango: El Jute, 1928, Calderon 2445 (F, US).

HONDURAS.-Dept. Yoro: El Portillo Grande, August 1937, von Hagen 1038 (F, NY); Aguan River Valley, vicinity of Coyoles, June 30, 1938, Yuncker, Koepper, and Wagner 8180 (DeP, F, Ill [type of Q. aguana], NY). DEP'. ComaYagua: hills above Siguatepeque, near El Achote, July 26, 1936, Y Yncker, Dawson, and Youse 6136 (DeP, F, MBG, Mi, US [isotypes of Q. achoteana]); about Siguatepeque, July 18, 1936, Yuncker, Dawson, and Youse 5961 (DeP, F, MBG, Mi, NY, US [isotypes as of Q. achoteana var. sublanosa]); about Siguatepeque, February 18, 1928, Standley 56184 (AA, F, US). Dept. TegucigalPa: Monte de la Flor, Tegucigalpa, December 1937, von Hagen 1206 and 1133 (F, NY).

NICARAGUA.- Prov. Bluefields: San Rafael del Norte, March 25-26, 1917, Miller and Griscom 23 (US). 
15. Quercus purulhana Trel., Mem. Nat. Acad. Sci. 20: 63. pl. 64. 1924.

Large (?) tree. Twigs moderate or rather coarse (2 to $4 \mathrm{~mm}$.), fluted, reddish brown, from sparsely villous becoming glabrous, with numerous pale prominent lenticels. Buds (mature?) about $2 \mathrm{~mm}$. long, ovoid, pilose or glabrescent, the stipules persistent for a while, about $8 \mathrm{~mm}$. long, narrowly ligulate, strigose dorsally. Leaves deciduous, moderately thick, about 10 to $20 \mathrm{~cm}$. long, 4 to $13 \mathrm{~cm}$. broad, obovate to oblong-elliptic, broadly rounded to acute at apex, cordulate to deeply cordate at base, obscurely to profoundly undulate with rounded or mucronate-tipped teeth, the cartilaginous margins flat or minutely revolute, upper surface somewhat shining, from minutely puberulent becoming glabrate except along the base of the midrib, lower surface persistently short-fulvous-velvety and only the veins glabrate, waxy where denuded; veins about 11 to 15 on each side, obviously or obscurely branching and anastomosing near the margin, in either case ultimately passing into the teeth, slightly impressed above, rather prominent beneath; petioles 3 to $5 \mathrm{~mm}$. long, reddish brown, puberulent or glabrate. Staminate catkins about $4 \mathrm{~cm}$. long, the tomentose rachis loosely flowered, the anthers moderately exserted. Pistillate catkins 2 to $4 \mathrm{~cm}$. long, 2- to 4 -flowered distally or along the tomentose peduncle. Fruit annual, solitary, paired, or in groups on a peduncle 1.5 to $2.5 \mathrm{~cm}$. long; young cups (about half grown) about $10 \mathrm{~mm}$. in diameter, apparently becoming deeply cupshaped, the scales prominently thickened basally, the narrow apices thin and loosely appressed, densely short-tomentose all over. Acorns? (See pls. 40 and 41.)

Range: British Honduras and Baja Verapaz, Guatemala.

Quercus purulhana was referred by Trelease to the series Macrophyllae Trel. Its reference to that group seems to have been prompted by the nature of the type specimen, which is obviously a shade branch with broadly obovate leaves, the largest in the size range of the species. A duplicate of the same collection has smaller oblong leaves similar to those of the other specimens referred to this species. Q. purulhana differs from $Q$. peduncularis and from the unrelated but similar $Q$. segoviensis in the dense short pubescence of the under surface of itsleaves.

Specimens examined:

BRITISH HONDURAS.-Great Southern Pine Ridge, September 1928, Stocker $6(\mathrm{~F})$

GUATEMala.-Dept. Baja Verapaz: Cuesta de Quililha, near Purulha, April 21, 1905, Pittier 163 (NY, US [2] [type as sheet no. 472817]) ; Rabinal, May 9, 1906, Cook 15 (US); between Sabinal and Rabinal, May 31, 1904, Cook and Doyle 285 (US); between Santa Rosa and Salama, June 5, 1904, Cook 266 (US).

Series Vicentenses Trel., Mem. Nat. Acad. Sci. 20: 58. 1924.

Large trees with glabrate twigs; leaves evergreen, medium-sized, oblong or lanceolate, subentire to coarsely toothed apically, glabrate above, rather tomentulose beneath, the lower surface waxy-glaucous; veins 10 to 15 on each side, impressed above, prominent beneath, anastomosing; petioles short; fruit short-pedunculate.

Range: El Salvador.

Includes: Q. vicentensis Trel. (type). 
16. Quercus vicentensis Trel., Mem. Nat. Acad. Sci. 20: 59. 1924.

Quercus comasaguana Trel., Mem. Nat. Acad. Sci. 20: 43. 1924.

Large tree. Twigs about $2 \mathrm{~mm}$. thick, obscurely fluted, from dark brown becoming gray, from scantily puberulent soon glabrate with prominent lenticels. Buds (fide Trel.) apparently glabrous, glossy brown, round-ovoid; the stipules caducous, about $6 \mathrm{~mm}$. long, ligulate, dorsally sparsely pubescent. Leaves evergreen, moderately thick and firm, about 7 to 10 or $15 \mathrm{~cm}$. long and 2 to 3.5 or $6 \mathrm{~cm}$. broad, oblong to lanceolate or oblanceolate, rounded to acute or narrowly rounded apically, cordulate or rounded to subcuneate at base, entire or coarsely toothed apically, margins flat or minutely revolute, upper surface dull, from sparingly glandular-puberulent becoming glabrate except along the base of the midrib, lower surface from densely creamytomentose rather persistently tomentulose, the denuded surface waxyglaucous; veins about 12 to 15 on each side, very irregular, obviously branching and anastomosing, somewhat impressed above, very prominent beneath; petioles about $5 \mathrm{~mm}$. long, persistently stellatepubescent or glabrate. Staminate catkins 3 to $4 \mathrm{~cm}$. long, the glandular-puberulent rachis loosely flowered, anthers moderately exserted. Pistillate catkins 1.5 to $2 \mathrm{~cm}$. long, the glandular-puberulent peduncle distally 2- or 3-flowered. Fruit? (See pls. 42 and 43.)

Range: Known only from El Salvador.

It is very difficult to assign relationships to this poorly known species. Its leaves are to some extent reminiscent of the Mexican series Obscurae Trel., but no specimens from the well-explored Guatemalan area have appeared to link the two. Until more complete Salvadoran specimens are available, the species must remain problematic, but there is no doubt of its distinctness from previously described entities.

It is not at all clear why Trelease assigned $Q$. comasaguana to his series Oocarpae from which its nearly glabrous twigs and basally scarcely narrowed and rather thick-bladed leaves amply separate it. The only known specimen is juvenile and apparently a shade form; therefore it is more densely pubescent and has rather expanded leaves. However, its identity with $Q$. vicentensis is obvious.

The oaks of El Salvador are badly in need of further collecting. No species is known from more than a few specimens, and one obviously undescribed species must go unnamed for lack of sufficiently mature material.

Specimens examined:

EL SALVADOR.- Comasagua, December 1922, Calderon 1430 (US [type of Q. comasaguana]). Dept. SAN Vicente: Volcan de San Vicente, March 7-8, 1922, Standley 21593 (US [type]).

Series Reticulatae Trel., Mem. Nat. Acad. Sci. 20: 72. 1924.

Shrubs to medium-sized trees with glabrate or usually pubescent twigs; buds ovoid, the stipules usually persistent; leaves medium-sized or sometimes small or very large, evergreen or deciduous, mostly obovate, entire to crenately pungent, markedly impressed-veiny and glabrate above, rather persistently tomentulose to densely woolly beneath or sometimes glabrate, the lower surface often waxy-glaucous; short-petiolate and often deeply cordate; fruit pedunculate, the cup scales usually merely puberulent, nut brown or reddish, the apices thin and very loosely appressed. 
Range: Southwestern United States, Mexico, and Guatemala.

Includes: Q. pilicaulis Trel. and several Mexican species, including Q. reticulata Humb. and Bonpl. (type).

17. Quercus pilicaulis Trel., Mem. Nat. Acad. Sci. 20: 67. pl. 77. 1924.

Quercus tomentosa $\beta$ bullata A. DC. in DC. Prodr. 16 ${ }^{2}: 33$. 1864.

Q. tomentosa o abbreviata A. DC. in DC. Prodr. 16 ${ }^{2}: 33.1864$.

Q. pilicaulis f. macrodonta Trel., Mem. Nat. Acad. Sci. 20: 68. pl. 78.1924.

Q. pilicaulis f. obovalis Trel., Mem. Nat. Acad. Sci. 20: 68. pl. 79. 1924.

Q. pilicaulis f. hurteri Trel., Mem. Nat. Acad. Sci. 20: 68. pl. 80. 1924.

Q. pilicaulis f. armata Trel., Mem. Nat. Acad. Sci. 20: 68. pl. 79. 1924.

Q. pilicaulis f. concava C. H. Mull., Amer. Midl. Nat. 18: 851. 1937.

Q. pilicaulis f. elongata C. H. Mull., Amer. Midl. Nat. 18: 851. 1937.

Q. pilicaulis f. exserta C. H. Mull., Amer. Midl. Nat. 18: 852. 1937.

Q. peduncularis subsp. pilicaulis A. Camus, Monogr. Genre Quercus 2: 601. pl. 197, f. 1-10. 1939.

Q. peduncularis subsp. hurteri A. Camus, Monogr. Genre Quercus 2: $603 . \quad p l .197, f .11-14 . \quad 1939$.

Large or small tree. Twigs coarse (2 to usually 3 or $4 \mathrm{~mm}$. thick), roundly fluted, brown or soon becoming gray with or without prominent lenticels, at first densely fulvous-tomentose, soon glabrate or somewhat persistently pubescent. Buds 2 to $3 \mathrm{~mm}$. long, broadly ovate to rounded, brown, glabrate; the stipules caducous or sometimes persistent about the terminal bud, 10 or $12 \mathrm{~mm}$. long, narrowly ligulate, dorsally strigose. Leaves evergreen, thick and leathery, 5 to usually 12 or even $20 \mathrm{~cm}$. long, 2.5 to usually 7 or even $12 \mathrm{~cm}$. broad, typically obovate to subrotund or suboblanceolate, broadly rounded at apex (or occasionally in toothed leaves the apical tooth acute), basally cordulate or usually markedly cordate, subentire to undulate, apiculate-undulate, or coarsely acute- or obtuse-toothed, margins cartilaginous and minutely revolute, the blade either flat or markedly crisped or occasionally ventrally deep-concave, upper surface from puberulent soon glabrate except along the midrib and principal veins, somewhat shining, lower surface persistently sparse- or dense-bufftomentose, the denuded surface rather prominently bullate; veins about 7 to 10 on each side, obviously branching and anastomosing near the margin but ultimately passing into the teeth, markedly impressed above (including the major reticulum but not the pale and slightly raised smallest veinlets), very prominent beneath; petioles 3 to $7 \mathrm{~mm}$. long, dark brown, tomentose or glabrate. Staminate catkins 6 to 10 $\mathrm{cm}$. long, fulvous-pilose, loosely flowered, the glabrous anthers much exserted. Pistillate catkins 1 to 10 or more cm. long, 2- to 15-flowered distally or along the stellate peduncle. Fruit annual, short- or longpedunculate, the peduncle 2 to $15 \mathrm{~cm}$. long, 1.5 to $2.5 \mathrm{~mm}$. thick, 
glabrate or pubescent, with numerous prominent light lenticels; cups usually about $14 \mathrm{~mm}$. broad (occasionally 20 or only $8 \mathrm{~mm}$.), usually hemispheric but sometimes deeply cup-shaped or deeply saucer-shaped, the margins straight or occasionally flaring, the scales narrowly ovate or cuneate, somewhat or not at all thickened basally, the narrowly rounded apices thin and often loosely appressed, densely puberulent or tomentose, buff or the glabrate scale tips deep red; acorns 15 to 23 $\mathrm{mm}$. long, 8 to $15 \mathrm{~mm}$. broad, ovoid to oblong or long-conic, obtuse or acute, smooth or longitudinally furrowed in drying, light brown, glabrate, one-third or only one-fifth included. (See pls. 44 to 49 .)

Range: Mountains of Guatemala and Chiapas; type from Guatemala (von Warscewicz 43) without further data.

Quercus pilicaulis is a well-marked and very constant species in its fundamental characters (texture, veining, and pubescence of the leaves, scales of the cups, and acorns). Yet, in leaf form, size and shape of fruit, and length of peduncle it presents numerous variations and combinations of variations which, in single specimens, seemed worthy of formal names. It does not now seem desirable to separate a forma exserta which in addition to its exserted acorns also has the elongate peduncles of $\mathrm{f}$. elongata, which in turn has the coarsely toothed leaves of $\mathrm{f}$. macrodonta. It rather seems that these variations may all be attributed to single and independently functional genes, which may appear in almost any population of the species.

Trelease referred this species to the series Pedunculares, but its constantly impressed-veiny leaves with often apiculate teeth and its cup scales with loosely appressed reddish-brown apices clearly indicate the series Reticulatae.

Specimens examined:

MEXICO.-ChIAPAS: Las Casas, February 1939, Martinez 367 (USNA); April 1939, Martinez 368 (USNA); Cintalapa, February 1939, Martinez 378 (USNA); Copainala, February 1939, Martinez 379 (USNA).

GUATEMALA.-Dept. HUenUetenango: without further data, August 1934, Skutch 1078 (F). DePt. SAN MARcos: above Rio Tacana, near San Antonio, February 22, 1939, Standley 66128 (F, USNA); Puente de Nahuatl-aa, near San Marcos, February 22, 1939, Standley 66206 (F). Dept. Quezaltenango: Cerro La Pedrera, south of Quezaltenango, February 18, 1939, Standley 66464 and 66468 (F) ; mountains above Olintepeque, February 20, 1939, Standley 65960 (F, USNA); above (north of) Olintepeque, January 29, 1941, Standley 85219 (USNA); Cerro Quemado, February 8, 1906, Kellerman 5922 (US); Volcan Santa Maria, January 24, 1896, Nelson 3721 (US); Volcan de Santa Maria, above Palojunoj, March 6, 1939, Standley 67585 (F); January 15, 1941, Standley 83582 (USNA); Quezaltenango, April 6, 1915, Trelease 34, 35, 36, 37, 38, 39, 40, 41, 42 (IIl [no. 37, type of f. hurteri]); April 7, 1915. Trelease 32, 33 (Ill.); 1922, Hurter 3, 3b, 4, 5, 6, 7, 8, 9 (IIl). Dept. Totonicapan: between San Francisco El Alto and Momostenango, January 19, 1941, Standley 84099 (USNA); region of Chui-quisis, between Totonicapan and Desconsuelo, January 23, 1941, Standley 84398 (USNA). Dept. Chimaltenango: Chichavac, November-December 1930, Skutch 50 (III, US); February 28, 1933, Skutch 296 (Mi, US); November 14, 1933, Skutch 684 (US); Skutch 685'(Ill [isotype of f. concava]); Skutch 686 (Ill, US); Skutch 687 (III [isotype of f. elongata]); Skutch 688 (Ill, US); November 19, 1933, Skutch 728 (US) ; Cerro de Tecpam, region of Santa Elena, December 26, 1938, Standley 60945 (F) ; Barranco de la Sierra, southeast of Patzum, December 31, 1938, Standley 61509 (F, USNA). Dept. Guatemala: Sapote, March 1890, Smith 1968 (G, NY, US); near Fiscal, December 12, 1938, Standley 59617 (F, USNA). Dept. Sacatepequez: Chillani, April 3, 1921, Rojas 367 (US). DePt. Jutiapa: Los Llanitos, near San Jose Acatempa, December 21, 1938, Standley 60599 (F).

Series Opacae Trel., Mem. Nat. Acad. Sci. 20: 92. 1924.

Shrubs or small trees with slender glabrate twigs; buds rounded, the stipules persistent or caducous; leaves small, thick and hard, 
elliptic to lanceolate or oblong, entire to few- or several-toothed, the veins not prominent, petioles short, glabrate and pruinose or persistently tomentose; fruit long- or usually short-pedunculate, rather small, the scales rather blunt, mostly brown-tipped and canescent.

Range: Mexico, Coahuila to Chiapas.

Includes: Q. sebifera Trel. and several Mexican species of which Q. opaca Trel. is the type.

18. Quercus sebifera Trel., Mem. Nat. Acad. Sci. 20: $93 . \quad p l .149$. 1924.

Quercus sebifera f. comitanensis Trel., Mem. Nat. Acad. Sci. 20: 93. $p l .149 .1924$.

Probably a shrub or small tree. Twigs 1 to $2 \mathrm{~mm}$. thick, fluted, from buff-tomentose becoming glabrate or for a time somewhat pubescent, becoming gray with scarcely evident lenticels. Buds $2 \mathrm{~mm}$. in diameter, rounded, glossy brown, glabrate; the stipules persistent, 3 to 4 $\mathrm{mm}$. long, subulate. Leaves persistent for 2 or 3 seasons, thick and hard, 2 to $6 \mathrm{~cm}$. long, 1 to $3 \mathrm{~cm}$. broad, oblong to elliptic, often broadest above the middle, apically rounded to subacute, basally cordulate or rounded, undulately few-toothed toward the apex or merely mucronate or entire, margins minute- or crisped-revolute, upper surface glossy, from buff-tomentose soon glabrate, lower surface similarly glabra te but dully waxy-glaucous; veins 6 to 9 on each side, very irregular, much branched and anastomosing toward the margin, scarcely evident above and only slightly raised beneath; petioles 1 to $6 \mathrm{~mm}$. long, either glabrate or persistently tomentose. Staminate catkins 2 to $5 \mathrm{~cm}$. long, rusty-tomentose, rather loosely flowered, the glabrous anthers scarcely exserted from the pilose perianth. Fruit annual, clustered distally on a peduncle 2 to $5 \mathrm{~cm}$. long; cups 10 to $13 \mathrm{~mm}$. broad, shallowly goblet-shaped, the scales ovate and rounded or deltoid and obtuse, obviously thickened basally, the apices closely appressed, puberulent especially toward the base; acorns? (See pl. 50.)

Range: Known only from Chiapas, Mexico (1,620 m.).

Quercus sebifera is related to several other Mexican species of the series Opacae, but it has no relatives in the Central American flora. Its small hard leaves, waxy-glaucous beneath with scarcely prominent veins, and its small cups clearly distinguish it from other species within this area. The f. comitanensis cannot be held distinct. Its leaves are minutely revolute as in the type, but the lack of coarse teeth (an ephemeral character) explains the failure of the margins to become crisped or falsely revolute.

Specimens examined:

MEXICO.-ChIAPAS: Comitan, June 6, 1906, Cook $\% 9$ (US [4] [type as sheet no. 860265]; June 14, 1906, Cook 78 (US [type of f. comitanensis]).

Series Virentes Trel., Mem. Nat. Acad. Sci. 20: 112. 1924.

Medium-sized or large trees or exceptionally shrubs with the twigs closely tomentose; leaves evergreen, rather small, entire or sometimes repandly or acutely few-toothed, glabrous above and minutely appressed-canescent beneath; reins inconspicuous or somewhat impressed above, only the principal ones raised beneath; fruit annual, pedunculate, with thin or keeled appressed scales. 
Range: Southeastern United States to Cuba, Baja California, and the Gulf Coast of Mexico to Panama.

Includes: Q. oleoides Schlecht. and Cham. and several United States and Mexican species including Q. virginiana Mill. (type).

19. Quercus oleoides Schlecht. and Cham., Linnaea 5: 79. 1830.

Quercus lutescens Mart. and Gal., Bul. Acad. Brux. 10: 219. 1843.

Q. oleoides var. australis Trel., Mem. Nat. Acad. Sci. 20: 114. pl. 192, 193.1924.

Q. oleoides f. lutescens Trel., Mem. Nat. Acad. Sci. 20: $114 . \quad p l$. 194. 1924.

Medium-sized or large tree. Twigs 1 to $2 \mathrm{~mm}$. thick, fluted, from densely short-stellate-tomentose becoming glabrate or persistently puberulent, gray, the lenticels rarely evident. Buds about $2 \mathrm{~mm}$. long, subrotund, broadly rounded, dark reddish brown, glabrate; stipules immediately caducous. Leaves evergreen, thick and rather hard, 4 to 8 or rarely $10 \mathrm{~cm}$. long, 2 to 4 or sometimes $6 \mathrm{~cm}$. broad, obovate to oblanceolate or rarely elliptic or rhomboid, broadly rounded to acute at apex, basally cuneate or subobtuse, entire or occasionally mucronately few-toothed especially toward the apex, margins minuteiy revolute, upper surface from stellate-puberulent becoming glabrous or persistently pubescent, somewhat shining, lower surface densely and minutely appressed-stellate-canescent, the veins often glabrate; veins about 6 or 8 on each side, much branched but obscurely anastomosing, scarcely evident above or slightly impressed, rather prominent below, the reticulum very obscure; petioles 4 to 6 (or sometimes 2 or 10) $\mathrm{mm}$. long, puberulent. Staminate catkins about $3 \mathrm{~cm}$. long, the puberulent rachis rather closely flowered, the puberulent anthers scarcely exserted. Pistillate catkins 5 to $25 \mathrm{~mm}$. long, 1- to 6- or 8-flowered distally or scattered on the puberulent peduncle. Fruit annual, solitary, paired, or several on a peduncle 1 to about $6 \mathrm{~cm}$. long; cups turbinate to hemispheric or deep-flaring, about 10 to usually 12 or $15 \mathrm{~mm}$. in diameter, the scales flat or somewhat keeled, not evidently thickened basally except in very young cups, broadly deltoid, rather acute, gray-puberulent; acorns 18 to $25 \mathrm{~mm}$. long, 13 to 18 $\mathrm{mm}$. broad, ovoid or elliptic, glabrous, light brown, about one-third or sometimes only one-fourth included. (See pls. 51 to 53.)

Range: Lowlands of eastern Mexico and Guatemala to Costa Rica, rarely reaching $1,000 \mathrm{~m}$. altitude; type from near Jalapa, Veracruz, Mexico (Schiede 23).

Quercus oleoides is the only member of the series Virentes reaching Central America, and is the only one south of the boundary region of northern Mexico. The forma lutescens is merely a juvenile leaf form which may appear on any shaded branch or root-sprout. The markedly toothed leaves of some specimens are the expression of this. The variety australis is scarcely distinct from the typical form in Mexico. Some of the Central American specimens bear cup scales in quite as definite vertical series as the type, and not all the material from the type region exhibits this character. This appears to be the sole basis for the variety.

Specimens examined:

MEXICO.-ChIAPAs: Sabana Palenque, July 9-14, 1939, Matuda 8792 (F, Mi); Motozintla, February 1939, Martinez $37 \%$ (USNA); Copainala, February 
1939, Martinez 375 (USNA); Coapilla, June 1939, Martinez 387 (USNA). TABAsco: Ojo 'Agua, Balancan, May 9-14, 1939, Matuda 3129 (F, Mi).

BRITISH HONDURAS.- Without further data, Kinloch 97 (F); between Mullins River and Manatee, August 16, 1940, Gentle 3378 (NY); Sein Bight, November 25, 1930, Schipp 672 (AA, F, MBG, Mi, NY). El CAyo District: Mountain Pine Ridge, San Agustin, July-August 1936, Lundell 6627 (F, MBG, Mi, NY, US) ; Lundell 6837 (Mi, USNA); March 1, 1936, Bartlett 11886 (DeP, Mi, NY); Little Mountain Pine Ridge, March 1, 1931, Bartlett 11873 (Mi, NY); Duck Run, February 17, 1931, Bartlett 11552 (Mi); Bartlett 11553 (AA, Mi, NY); April 24, 1931, Bartlett 12976 (Mi, NY); Bartlett 12979 (AA, DeP, Mi, NY). STANn Creek District: Sarawee Pine Ridge, February 18, 1939, Gentle 2695 (F, Mi, NY, USNA); Stann Creek Railway, May 12, 1929, Schipp 209 (AA, F, MBG, Mi [2], NY, US) Belize District: without further data, January-June 1936, Lundell 6964 (F, MBG, Mi, NY); Big Fall Pine Ridge, April 28, 1933, Lundell 4347 (F, Mi, USNA); Boomtown, August 23, 1936, O'Neili 8555 (NY); September 13, 1936, O'Neill 8554 (F, Mi, NY, US); Belize, ridge near aviation field, January 28, 1931, Bartlett 11203 (DeP, Mi, NY); Cornhouse Creek, January 31, 1931, Bartlett 11308 (DeP, Mi, NY); Bartlett 11313 (AA, Mi, NY).

GUATEMALA.- Without further data, Friedrichsthal without number (NY); Santa Ines, February 25, 1927, Galusser 1 (F, US). DePt. Peten: Logwood Swamp, Dos Arroyos, March 15, 1931, Bartlett 12112 (Mi, US). Dept. Alta Verapaz: near Finea Sepacuite, March 31, 1902, Cook and Griggs 318 (US). Dept. Izabal: between Izabal and Los Amates, May 31, 1919, Blake 7735 (US). Dept. ZaCAPA: Gualan, January 20, 1905, Deam 159 (G, Mi); El Ojillal de Cenizas, between Gualan and Copan, January 1907, Pittier 1789 (US) ; El Jute, near Copan, December 1906-January 1907, Pittier 1818 (NY, US).

HONDURAS.-Olanchita, February 14, 1927, Record and Kuylen 53 and $53 A$ (US). Dept. Santa Barbara: San Pedro Sula, April 1887, Thieme 5615 (G, US [2]). Dept. Copan: Hac. Espiritu Santo, May 10, 1919, Whitford and Stadtmiller 41 (US); Macuelizo, May 19, 1919, Whitford and Stadtmiller 55 (US). Dept. Yoro: Subirana, September 1937, von Hagen 1095 (F, NY); near Las Flores, vicinity of Coyoles, Aguan River Valley, June 30, 1938, Yuncker, Koepper, and Wagner 8179 (DeP, F, MBG, Mi, NY). Dept. Comayagua: Coyocuteno, San Luis, May 27, 1932, Edwards 323 (AA, F); Las Limas, July 1, 1932, Edwards 375 (AA, F, US); Comayagua, February 23, 1933, Edwards 578 (AA [2], F, US).

COSTA RICA.-Prov. Guanacaste: between Guachipelin and Liberia, May 27, 1932, Brenes 15590 (F); between Los Abogados and Liberia, July 1890, Pittier 2607 (US [2] [isotypes of var. australis]); between Carretera and Santa Maria, near Liberia, January 14, 1930, Dodge and Thomas 6232 (F, MBG, Mi, US).

II. SUBGENUS ERYTHROBALANUS (Spach) Oerst., K. Danske Vidensk. Selsk. Skrift. 9: 358. 1871.

Erythrobalanus Spach, Hist. Nat. Veg. Phen. 11: 160. 1842 (as section).

Erythrobalanus Endl., Gen. Pl. Sup. $4^{2}$ : 24.1847 (as subdivision of Quercus without indication of rank).

Erythrobalanus Schwarz, Notizbl. Bot. Gart. Mus. Berlin-Dahlem 13: 8. 1936 (as genus).

Shrubs or usually large trees with the bark rough and deeply furrowed or rather smooth but not scaly and never soft or corky, usually black or very dark; wood usually reddish, the ducts seldom containing tyloses, the smaller (summer wood) ducts always thick-walled ( $3 \mu$ or more) and round; leaves deciduous or evergreen, never round-lobed, if toothed then the teeth aristate-tipped, often entire and the apex aristate or not; stamens usually 6 , anthers apiculate or mucronate (or not); styles elongate, gradually dilated into spatulate stigmas; fruit annual or biennial (maturing in 1 or 2 years), cup scales narrowed or broad, thin, rarely corky-thickened basally, abortive ovules apical or rarely basal or deeply lateral, the acorn shell densely tomentose within.

Type species: Quercus phellos L. 
Series Andinae Trel., Mem. Nat. Acad. Sci. 20: 141. 1924.

Medium-sized or large trees; twigs thick, from loose-tomentose glabrate with very prominent lenticels; buds ovoid to subfusiform, from loose-tomentose becoming glabrate; stipules caducous; leaves deciduous or subevergreen, moderately large, lanceolate to oblanceolate, often acuminate, entire or rarely coarsely toothed about the apex, quickly or tardily glabrate beneath; petioles short or moderately long; fruit annual, subsessile, medium-sized or rather large, the cup scales rather loosely appressed, fulvous-pubescent.

Range: The Colombian Andes and adjacent Panama.

Includes: Q. humboldtii Bonpl., the type.

20. Quercus humboldtii Bonpl. in Humboldt and Bonpland, Pl. Aequinoct. 2: $155 . \quad p l .130 .1809$.

Quercus tolimensis Humb. and Bonpl., Pl. Aequinoct. 2: 153. pl. 129. 1809.

Q. almaguerensis Humb. and Bonpl., Pl. Aequinoct. 2: 157. pl. 131. 1809.

Q. lindeni A. DC. in DC. Prodr. $16^{2}$ : 32.1864.

Q. humboldtii var. lehmanniana Hieron. ex Trel., Mem. Nat. Acad. Sci. 20: 142.1924.

Erythrobalanus humboldtii Schwarz, Notizbl. Bot. Gart. Mus. Berlin-Dahlem 13: 496.1937.

E. tolimensis Schwarz, Notizbl. Bot. Gart. Mus. Berlin-Dahlem 13: 496.1937.

E. lindeni Schwarz, Notizbl. Bot. Gart. Mus. Berlin-Dahlem 13: 496. 1937.

E. duqueana Schwarz, Notizbl. Bot. Gart. Mus. Berlin-Dahlem 13: 495.1937.

Medium-sized or large tree. Twigs 2 to 4 or rarely $7 \mathrm{~mm}$. thick, fluted or subterete, from loosely fulvous-tomentose quickly or tardily becoming glabrate, the numerous light lenticels raised and very prominent. Buds about $5 \mathrm{~mm}$. long, ovoid or elongating and acute, from loosely tomentose becoming glabrate and dull brown but the scales ciliate; the ligulate stipules rather early caducous. Leaves subevergreen or clearly evergreen, rather thin but hard and coriaceous, 10 to $20 \mathrm{~cm}$. long, 3 to $7 \mathrm{~cm}$. broad, lanceolate to elliptic or oblanceolate, acute or long-acuminate at apex, cuneate to rounded at base, entire or rarely coarsely few-toothed near the apex, margins minutely cartilaginous-revolute, flat or minutely crisped, upper surface glabrous and somewhat shining or the base of the midrib persistently tomentose, lower surface glabrate or rather persistently floccose especially along the midrib, opaque or somewhat shining, not bullate; veins about 12 to 16 on each side, branching and very obviously anastomosing near the margin, impressed above but slightly raised within the grooves, very prominent beneath, the reticulum rather inconspicuously raised beneath, less so above; petioles 4 to 10 or $15 \mathrm{~mm}$. long, glabrate or persistently tomentose. Staminate catkins 8 to $15 \mathrm{~cm}$. long, rather loosely flowered, the rachis sparsely villous, the obtuse anthers well exserted from the villous perianth. Pistillate catkins about $1 \mathrm{~cm}$. long, 1- or 2-flowered. Fruit annual, solitary or paired on a peduncle 3 to $10 \mathrm{~mm}$. long and 3 to $6 \mathrm{~mm}$. thick with very prominent lenticels; cups 2 to $3 \mathrm{~cm}$. broad, deeply or shallowly cup-shaped, the margins 
inrolled or not, the scales narrowly orate, obtuse, rather loosely appressed, short-fulrous-tomentose; acorns 2 to $3 \mathrm{~cm}$. long, 1.5 to 2 $\mathrm{cm}$. broad, round or oroid, from loosely silky-tomentose becoming glabrate and brown, one-half or usually one-third included. (See pls. 54 to 57.$)$

Range: Colombian Andes and adjacent Panama (1,500 to 3,400 m.); type from Popayan, Colombia (Bonpland 2083).

Quercus humboldtii is readily distinguished from other annual-fruited species of the subgenus Erythrobalanus by its large lanceolate or oblanceolate and usually entire leares and its rather large cups with fulvous-tomentose loosely appressed scales. It is related to $Q$. costaricensis in the nature of its fruit and in bearing the aborted orules laterally or basally in the acorn, but the regetative characters of the two species are so utterly different as to indicate at most a rather remote relationship.

Until recent years there has not been available for study a very complete series of Andean Quercus. The few collections at the disposal of Humboldt and Bonpland and later of de Candolle were insufficient to reveal their identities as one polvmorphic species differing only in the luxuriance of the foliage and persistence of tomentum along the midrib beneath. A form with twigs and under surface of leares denselr buff-tomentose and tardily glabrate (Perez and Cuatrecasas 8100) is about representative of the plant named Q. tolimensis except that the specimen here cited also has rather small leares. Tendencies toward this extreme pubescence occur here and there in the range of the species. It is very doubtful that this rariation represents more than a casual form. Erythrobalanus duqueana differs even less than the other proposed species, and to recognize it as distinct would necessitate the recognition of numerous additional minute variants as yet undescribed.

A specimen in the New York Botanical Garden (Hayes 830) is labeled merely "Panama, 1859-1860." The plant clearly belongs to this species. but no other collections from Panama have ever been found. No record of Hayes having collected in Colombia was encountered. It is verr likely that the Haves specimen was taken in lower Panama near Colombia. since no specimens of this species have been turned up in the recent intensive explorations of the Chiriqui region.

Specimens examined:

PÁNAMA.-Prov. DARIEN (?): without data, 1859-1860, Hayes 830 (NY).

COLOMBIA.-Without locality, 1783-1808, Mutis 5103 (F). Dept. SanTANDER: Eastern Cordillera, Mesa de los Santos, December 11-15, 1926, Killip and Smith 15296 (NY, US); vicinity of Las Vegas, December 21-23, 1926, Killip and Smith, 15895 (NY, US); Rio Surata valley, above Surata, January 5-6, 1927, Killip and Smith 16744 (NY, US); west slope of Paramo de las Puentes, above la Baja, January 25-31, 1927, Killip and Smith $1826 \%$ (NY, US); vicinity of Charta, February 1-11, 1927, Killip and Smith 19078 (F, NY, US). DEPt. BoyacA: near Tunja, 1849, Linden 1325 (NY [2] [isotypes of Q. lindeni]); Maripi, July 21, 1936, Garcia 4853 (US); Bosques de Arcabuco, February 24, 1940, Perez and Cuatrecasas 8100 (US [2]). Dept. Cundinamarca: "El Colegio," February 1916, Dawe $5 \tilde{5}$ (US); Fusagasuga, February 1876, Andre $1 \gamma 1$ (F, NT); February 5, 1876, Andre 1433 (F): Tequendama, October 28, 1917, Pennell 2640 (F, NY", U'S): below falls of Tequendama on Bogota River, December 19, 1929, Niemeyer 210 (US); Salto de Tequendama, October 1-3, 1938, Cuatrecasas 113 (US); Caparrapi, June 8-13, 1939, Garcia 7746 (US). Com. CAqueta: Cordillera Oriental, eastern slope, Quebrada del Rio Hacha, Cajon de Pulido, March 26, 1940, Cuatrecasas 8784 (CS); Sucre, April 4, 1940, Cuatrecasas 90\%6 (L'S). DePT. 
Tolima: Cordillera del Quindio, 1918, Dawe 798 (NY). Dept. antioquia: Cordillera above Antioquia, October 1884, Lehmann 3899 (US); La Ceja, July 1934, Bro. Daniel 384 (US); San Pedro, April 28, 1940, Bro. Thomas 766 (US.) Dept. Caldas: Cordillera Central, Rio Santa Rita, Salento, July 29, 1922, Killip and Hazen 9024 (NY, US). DEPT. VAlle: Cordillera Central, Rio Nima, near Palmira, April 1, 1937, Duque 567 (US, USNA [both photographs of isotype of Erythrobalanus duqueana]). DEPT. CAUCA: Rio Cauca, near Popayan, February 1884, Lehmann 3560 (US); Cauca Valley, between Rio Piendamo and Rio Palace, June 6, 1922, Pennell and Killip 6396 (NY, US); Rio Ortega, June 27, 1922, Pennell and Killip 7244 (NY); Popayan, January 22, 1935, Perez 3092 (US); Matorrales en Rio Blanco, near Popayan, July 9, 1939, Perez and Cuatrecasas 5801 (US); mountains above Popayan, without date, Hartweg 1393 (NY), Distr. Alejandria, February 1938, Dryander 2079 (US).

Series Benthamiae Trel., Mem. Nat. Acad. Sci. 20: 146.1924.

Medium-sized or large trees with glabrate or pubescent twigs; buds fusiform, apically fulvous-tomentose; leaves lance-elliptic, mediumsized, glabrate except the tomentose midrib beneath, veins raised on both surfaces, petioles 1 to $2 \mathrm{~cm}$. long; fruit annual, cups hemispheric, rather large, the finely fulvous-sericeous scales loosely appressed, acorns hemispheric or depressed-globose, densely fulvous-tomentose or glabrate, about one-half or more included; abortive ovules apical.

Range: Guatemala and Chiapas.

Includes: Q. benthami A. DC. (type).

Although the fruit of this series approximates the type of fruit seen in $Q$. humboldtii and $Q$. costaricensis, this series can scarcely be combined with either of these. It is most closely related to the series Andinae. This questionable relationship is discussed under the following species.

21. Quercus benthami A. DC. in DC. Prodr. $16^{2}: 29.1864$.

Quercus gemmata Trel., Mem. Nat. Acad. Sci. 20: 152. pl. 299. 1924.

Medium-sized or large tree. Twigs 1.5 to 2 or $3 \mathrm{~mm}$. thick, obscurely fluted, from densely short-velvety-tomentose quickly glabrate or persistently fulvous-pubescent into the second year, dark reddish brown when glabrate, with numerous raised and usually conspicuous light lenticles. Buds 5 to $7 \mathrm{~mm}$. long, 2 to $3 \mathrm{~mm}$. thick, fusiform, light or dark brown and fulvous-tomentose or glabrate except the conspicuously fulvous-ciliate scales; stipules caducous. Leaves deciduous (?) or distinctly evergreen, moderately thin but firm and coriaceous, 5 to usually 7 or 8 or sometimes $10 \mathrm{~cm}$. long, 2 to usually 3 or sometimes $5 \mathrm{~cm}$. broad, apices acute to attenuate-acuminate but rarely aristate-tipped, bases cuneate or from broadly rounded to narrowly acute, entire, margins finely but distinctly revolute, finely crisped or flat, upper surface glabrate and somewhat shining, lower surface coarsely fulvous-tomentose along the midrib and in the axils, otherwise glabrate and shiny; veins about 10 to 12 on each side with occasional evanescent intermediates, often arising at an angle less than 45 degrees, usually branching and rather obscurely anastomosing, raised above and more prominently so beneath, the reticulum slightly prominent on both surfaces; petioles 10 to $20 \mathrm{~mm}$. long, rather prominently winged especially toward the blade, minutely tomentose or glabrate. Catkins? Fruit annual, solitary or paired, subsessile or on a peduncle 3 to $5 \mathrm{~mm}$. long and 2 to usually 3 or $5 \mathrm{~mm}$. thick; 
cups 20 to $22 \mathrm{~mm}$. broad, hemispheric, the bases rounded or somewhat constricted, margins not inrolled, scales oblong or narrowly orate, the apices narrowed but truncate or rounded, loosely appressed. finely fulrous-tomentose; acorns depressed-globose or hemispheric, densely fulrous-sericeous or glabrate and light brown, one-half or more included; abortive ovules apical. (See pls. 58 and 59.)

Range: Mountains of southern Guatemala and Chiapas (about 1,500 to $3,000 \mathrm{~m}$.).

The large cups with loosely appressed scales and long buds with fulvous-ciliate scales adequately distinguish $Q$. benthami from the other annual-fruited species, whereas the same characters together with its annual fruition separate it from $Q$. acatenangensis, which sometimes has similar leares. Sterile specimens of Q. seemanni are very difficult to separate from $Q$. benthami except by the long, ciliatescaled buds of the latter. The former species is known only from Costa Rica, howerer, and there are sufficient fruiting specimens to establish the nature of its cup scales as tightly appressed.

The annual-fruited species of Erythrobalanus with moderately large cups and loosely appressed fulvous scales would seem to form a natural group. Q. humboldtii, Q. costaricensis, and $Q$. benthami have this type of fruit in common. Howerer, of these species, Q. benthami is the only one with apical aborted orules, and $Q$. costaricensis is the only one with leares broadly rounded and granular-bullate on the lower surface. Trelease characterized Q. gemmata as haring leares "very obtuse". His photograph of the type clearly indicates it to be conspecific with $Q$. benthami and shows its rerv obtuse leaves to be totally lacking apices by which to judge this point. The relationship of $Q$. benthami is rery problematic. It probably is more closely related to the Andean $Q$. humboldtii than to any other known species, but its apical abortive ovules make its reference to the Andinae difficult.

Specimens examined:

MEXICO.-Chiafas: Mount Tacana, August 1938, Matuda 2386 (USNA [3]) ; Mount Ovando, November 14-18, 1939, Matuda 3935 (USNA).

GUATEMALA.-DEPT. SAN MARcos: northeast flank of Volcan Tacana, vicinity of San Rafael (3 miles from Chiapas boundary), February 20, 1940, Steyermark 36212 and 36274 (F, USNA); near southeast portion of Volcan Tacana, between Conjula and La Union Juarez, February 22, 1940, Steyermark 36376 and 36389 (F, USNA); south slopes of Volcan Tajumulco, above Finca El Porvenir, March 8, 1940, Steyermark 37267 (F). Dept. Quezaltenango: slopes of Volcan Zunil about Aguas Amargas, February 17, 1939, Standley 65403 (F, USNA); Santa Maria, without date, Hartweg 563 (NY [isotype]). Dept. Chimaltenango: Chichavac, November 16, 1933, Skutch 692 and 693 (US). Dept. Jutiapa: Volcan Suchitan, northwest of Asuncion Mita, November 18, 1939, Steyermark 31947 (F)

Series Costaricanses Trel., Mem. Nat. Acad. Sci. 20: 145. 1924.

Medium-sized trees; twigs thick, from sparsely long-tomentose becoming glabrate and russet brown; buds large, ovoid or elongated, tomentose or glabrate; leaves persistent, medium-sized, elliptic or orate, obtuse, impressed-reiny and glabrate above, rather persistently loose-tomentose beneath with prominent veins and prominently bullate lamina, petioles short; staminate catkins fulvous-tomentose; fruit annual, short-stalked, rather large, the glabrate cup scales thin and loosely appressed, abortive ovules lateral or basal as in Lepidobalanus.

Range: Mountains of Costa Rica.

Includes: Q. costaricensis Liebm. (type). 
22. Quercus costaricensis Liebm., Overs. Danske Vidensk. Selsk. Forhandl. 1854: 184. 1854.

Q. costaricensis f. kuntzei Trel., Mem. Nat. Acad. Sci. 20: 146. pl. 283. 1924 (pro parte - exclusive of the type).

Q. endresi Trel., Mem. Nat. Acad. Sci. 20: 145. pl. 280. 1924.

Medium-sized or large tree. Twigs 2 to $4 \mathrm{~mm}$. thick, subterete, dark reddish brown with numerous small light lenticels, from densely loose-fulvous-tomentose becoming glabrate or for a time persistently floccose, gray the second year. Buds $6 \mathrm{~mm}$. long and $4 \mathrm{~mm}$. thick, ovoid, sparsely tomentose or glabrescent; the stipules caducous. Leaves evergreen, rather thick and very coriaceous, 3 to usually 6 or even $9 \mathrm{~cm}$. long, 2 to usually 3.5 or even $5 \mathrm{~cm}$. broad, elliptic or ovate, the apex broadly rounded or rarely subacute, the base broadly rounded or cordulate, rarely subcuneate, entire, usually crisped, markedly revolute and cartilaginous at the margin, upper surface glabrate or sparingly stellate along the veins and midrib, dull or somewhat shiny, impressed-reticulate, the principal veins and midrib raised within the depressions, lower surface persistently rather sparsely tomentose specially along the midrib or rarely glabrate, prominently raised-reticulate, the lamina rather prominently or inconspicuously bullate; veins 7 to 9 on each side, repeatedly branching and anastomosing toward the margin, impressed above but the principal ones raised within the depression, prominently raised (sometimes including the reticulum) beneath; petioles 2 to usually 4 or rarely even $10 \mathrm{~mm}$. long, glabrate or rather persistently tomentose. Staminate catkins about $6 \mathrm{~cm}$. long, from densely fulvous-tomentose becoming glabrescent, loosely flowered, the glabrous anthers exserted from the campanulate perianth. Pistillate catkins 1- or 2-flowered on a coarse peduncle 5 or $10 \mathrm{~mm}$. long. Fruit annual, solitary or paired on a peduncle 5 to $10 \mathrm{~mm}$. long, 4 to $5 \mathrm{~mm}$. thick, with prominent light lenticels, or subsessile; cups $25 \mathrm{~mm}$. broad, 12 to $15 \mathrm{~mm}$. high, gobletshaped, the base constricted, the scales oblong-ovate, truncate at the long narrow apex, thin but loosely appressed, light brown and dull, glabrous except the canescent apices; acorns hemispheric, 20 to $22 \mathrm{~mm}$. in diameter, glabrous or the apex sparsely puberulent, about one-half included, or (fide Trel.) 20 to $30 \mathrm{~mm}$. long and included at the base only. (See pls. 60 and 61. )

Range: Mountains of central Costa Rica; type from Volcan Irazu (Oersted 3465).

Quercus costaricensis is not very closely related to any other known species, but the loose cup scales suggest a relationship with the series Andinae, which has a totally different type of leaf. The impressed veins and prominent reticulum of this species are very like those of $Q$. irazuensis with which certain forms of $Q$. costaricensis are readily confused. The small broad leaves with rounded apices, the lower surface granuiar-bullate and persistently tomentose, and the inconspicuously raised reticulum of typical $Q$. costaricensis readily distinguish the species from $Q$. irazuensis whose larger leaves are much narrowed at the ends, the apices acuminate, the lower surface smooth and glabrate, and the reticulum prominently raised. Some forms of $Q$. costaricensis lack one or another of these distinguishing characters but never all of them. 
The forma kuntzei is very thoroughly confused. The type of this form (Kuntze 2282, at the New York Botanical Garden) is not conspecific with $Q$. costaricensis but belongs to $Q$. copeyensis, a species of Lepidobalanus. A duplicate of this number in the National Museum is clearly Q. costaricensis but scarcely deserves distinction as a form of that species. Trelease does not state which specimen actually is the type, but this is determined by his jllustration of the type which is so designated in the explanation of his plate 283. Q. endresi is simply an elongate leaf form of this species.

Specimens examined:

COSTA RICA.-Without further data, Warscewicz 53 (G). Prov. San Jose: Cerro de las Vueltas, December 29, 1925-January 1, 1926, Standley and Valerio 43564 and 43671 (F, US). Prov. Cartago: Volcan Irazu, Papales de San Juan, January 1, 1901, Pittier 14120 (US [2]) ; Volcan Irazu, June 24, 1874, Kuntze 2282 (US [type number but not conspecific with the type of f. kuntzei Trel.]); Kuntze 2352 (NY); August 4-5, 1920, Rowlee and Stork 940 (NY, US); June 28, 1923 , Stork 347 (US); December 1, 1937-January 1, 1938, Allen 672 (F, MBG); October 27, 1940, Seibert 1619 (USNA); east of Volcan Irazu, Pastores Finca of David Gutierrez, May 17, 1925, Stork 2089 (F); southwest of Volcan Irazu, Sabana Azul near Revantado, January 25, 1889, Pittier 871 (US).

Series Irazuenses Trel., Mem. Nat. Acad. Sci. 20: 144. 1924.

Medium-sized trees; twigs somewhat thick, glabrate; buds ovoidfusiform, the stipules caducous or somewhat persistent; leares large, narrowly elliptic to lanceolate or oblanceolate, entire, soon glabrate, impressed-veiny above, prominently raised-reticulate beneath, very short-petioled; fruit biennial (?), medium-sized, short-stalked, the cup scales thin, appressed, canescent.

Range: Sierra Madre Oriental of Mexico and mountains of Costa Rica.

Includes: Quercus irazuensis Kuntze (type) and questionably the Mexican Q. rysophylla Weatherby.

\section{Quercus irazuensis Kuntze, Rev. Gen. Pl. 2: 641. 1891.}

Medium-sized or large tree. Twigs 1.5 to 3 or $4 \mathrm{~mm}$. thick, fluted, dark brown, from fulvous-tomentose quickly glabrescent, becoming gravish the second year with few small raised lenticels. Buds about 3 or $4 \mathrm{~mm}$. long, ovoid, obtuse or acute, sparsely fulvous-tomentose; stipules caducous or persistent, 8 to $10 \mathrm{~mm}$. long, light brown or buff, sparsely tomentose. Leares evergreen, thin but firm and coriaceous, 6 to usually 10 or even $18 \mathrm{~cm}$. long, 2.5 to usually 4 or even $6 \mathrm{~cm}$. broad, narrowly elliptic to elliptic-lanceolate, short-acuminate to obtuse or rarely individually rounded at apex, the base narrowed, rounded or cordulate, entire or slightly undulate above the middle, cartilaginous-rerolute, upper surface not bullate, glossy and glabrate or sometimes stellate-pubescent at the base of the midrib, impressedreticulate, the midrib and principal reins raised within the depressions, lower surface dull, prominently raised-reticulate, the lamina obscurely bullate and usually markedly concare between the raised veinlets; reins about 10 or 12 on each side, often with evanescent intermediates, much branched and conspicuously anastomosing, often doubly or triply so, prominently raised (including the reticulum) beneath, impressed and the principal ones raised within the depressions above; petioles 2 to $3 \mathrm{~mm}$. long, from fulvous-tomentose glabrescent or for a time persistently stellate. Catkins and fruit? (See pls. 62 and 63.)

Range: Mountains of central Costa Rica. 
Quercus irazuensis is possibly closely related to Q. rysophylla Weatherby of northeastern Mexico, from which it is distinguished by its pubescence and smaller leaves with shorter apices and merely subcordate bases. Because the fruit of Q. irazuensis is unknown, this point is not assured. Certain forms of Q. costaricensis are difficult to distinguish from $Q$. irazuensis. The distinction is discussed under Q. costaricensis.

\section{Specimens examined:}

COSTA RICA.-Cerro de la Muerta, June 27, 1932, Stork 3052 (F). Prov. San Jose: Cerro de las Vueltas, December 29, 1925-January 1, 1926, Standley and Valerio 43752, 43789, and 43972 (F, US). Prov. Cartago: Volcan Irazu, June 24, 1874, Kuntze 2344 (NY [type]).

Series Aristatae Trel., Mem. Nat. Acad. Sci. 20: 139. 1924.

Series Perseaefoliae Trel., Mem. Nat. Acad. Sci. 20: 148. 1924. Series Parviglandes Trel., Mem. Nat. Acad. Sci. 20: 151. 1924. Series Eugeniaefoliae Trel., Mem. Nat. Acad. Sci. 20: 161.1924

Medium-sized trees; twigs slender or rather thick, persistently tomentose or glabrate; buds ovoid to fusiform; leaves mediumsized, elliptic-obovate to lanceolate, entire or mucronate- or aristatetoothed, glabrous above, glabrate beneath, the veins finely raised above, rather prominent beneath, the lamina smooth and often waxyglaucous beneath, petioles short or moderately long; fruit annual, small, the scales thin, appressed, and tomentose.

Range: Sierra Madre Occidental of Mexico, Chiapas, Guatemala, El Salvador, and Honduras.

Includes: Q. hondurensis Trel., Q. duratifolia C. H. Mull., Q. sapotaefolia Liebm., Q. eugeniaefolia Liebm., and several Mexican species of which Q. aristata Hook. and Arn. is the type.

The very close relationship of $Q$. hondurensis, $Q$. sapotaefolia, and $Q$. eugeniaefolia scarcely allows separate series for the latter two species.

24. Quercus hondurensis Trel., Mem. Nat. Acad. Sci. 20: 140. pl. 266. 1924.

Quercus comayaguana Trel. in Standley, Journ. Arn. Arb. 11: 25. 1930.

Q. guayabalana Trel. in Standley, Field Mus. Bot. Ser. 8: 6. 1930.

Q. yoroensis Trel. in Yuncker, Field Mus. Bot. Ser. 9: 282.1940.

Q. yoroensis var. aguanana Trel. in Yuncker, Field Mus. Bot. Ser. 9: 282.1940.

Medium-sized or large tree. Twigs 2 to 3 or $4 \mathrm{~mm}$. thick, somewhat fluted, persistently yellow- or buff-velvety-tomentose, the second season hoary, dark reddish brown where denuded, lenticels not or scarcely discernible. Buds about $5 \mathrm{~mm}$. long, broadly fusiform, apparently glabrous; stipules caducous. Leaves evergreen, 8 to usually 12 or 14 or even $18 \mathrm{~cm}$. long, 3 to usually 5 or $6 \mathrm{~cm}$. broad, lance-elliptic, oblong, or oblanceolate, obtuse to usually acute or acuminate or rarely rounded at apex, aristate-tipped or not, cordate or merely rounded at base, entire or slightly wavy and usually markedly crisped, margins minutely or coarsely revolute, upper surface somewhat shining, from minutely stellate-pubescent soon glabrate, but the midrib persistently tomentose, lower surface similar, 
not bullate; veins 8 to usually 10 or 12 on each side, branching and obviously anastomosing toward the margin, the principal ones slightly impressed above, very prominent beneath, the reticulum somewhat raised; petioles 5 to $10 \mathrm{~mm}$. long, yellow- or buff-velvetytomentose like the twigs. Staminate catkins 5 to $10 \mathrm{~cm}$. long, villous, sparsely flowered, the anthers well exserted. Pistillate catkins? Fruit annual, solitary or paired on a yellow-tomentose or rather glabrescent peduncle 5 to $10 \mathrm{~mm}$.long; young cups rather small, half-round or the base constricted, the scales ovate, thin, buff-tomentose, the narrowed apices rounded, closely appressed; young acorns from sericeous becoming glabrate and light brown, becoming exserted while half-grown. (See pls. 64 and 65.)

Range: British Honduras, Guatemala, Honduras, and El Salvador (lower mountain slopes).

Quercus hondurensis is the most extreme member of the series Aristatae and probably grows under the most tropical conditions, ranging in elevation from 300 to $1,500 \mathrm{~m}$. It is readily distinguished from Q. sapotaefolia and other Central American members of the series by its large characteristically acuminate and cordate leaves, tomentose twigs and petioles, and lack of evident lenticels.

Specimens examined:

BRITISH HONDURAS.-Ex Cayo Dist. : Mountain Pine Ridge, San Agustin, July-August 1936, Lundell 6758 (Mi, NY, US, USNA).

GUATEMALA.-Dept. ZACAPA: Sierra de las Minas, above Rio Hondo at Finca Alejandria, October 11, 1939, Steyermark 29580 and 29724 (F).

EL SALVADOR.-Dept. Chalantenango: El Jute, 1928, Calderon 2444 (F); Calderon 2447 (F, US). Dept. Morazan: Sierra de Osicala, 1929, Calderon 2508 and $2510(\mathrm{~F})$.

HONDURAS.-San Pedro Sula, Thieme 5440 (US [type]). Dept. Copan: Cuesta Zompopero, between Hac. Espiritu Santo and Quebrada Mojanales, May 15, 1919, Blake 7449 (US); Macuelizo, May 19, 1919, Whitford and Stadtmiller 56 (US). Dept. Yoro: Portillo Grande, August 1937, von Hagen 1045 (F, NY); Aguan River valley, vicinity of Coyoles, June 30, 1938, Y uncker, Koepper, and Wagner 8181 (DeP, F, NY [isotypes of Q. yoroensis]); Yuncker, Koepper, and Wagner 8185 (DeP, F. MBG, Mi, NY [isotypes of Q. yoroensis var. aguanana]). Dept. Comayagua: El Achote near Siguatepeque, February 18, 1928, Standley 56133 (AA, F, US); Siguatepeque, February 14-27, 1928, Standley 56229 (AA, F [type of Q. comayaguana]); Las Jaguas, Minas de Oro, May 5, 1932, Edwards, 185 (AA, F).

\section{Quercus duratifolia sp. nov.13}

Tree to $15 \mathrm{~m}$. tall and $0.5 \mathrm{~m}$. in trunk diameter. Twigs 1 to $2 \mathrm{~mm}$. thick fluted, from sparsely short-buff-tomentose glabrate and gray (or reddish brown if rubbed), lenticels few and very inconspicuous. Buds 2 or $3 \mathrm{~mm}$. long, ovoid, acute or rounded, dull brown, glabrate or pubescent about the apex; the ligulate stipules early caducous. Leaves evergreen (persisting two or three seasons), very thick and hard, 5 to usually 7 or $10 \mathrm{~cm}$. long, 2 to 3 or $3.5 \mathrm{~cm}$. broad, elliptic to oblong or oblanceolate, apex narrowly or broadly rounded, rarely aristatetipped or acute, base cordate or narrowly rounded, entire, margins rather strongly revolute, little if at all crisped, upper surface glabrous and highly polished (as though shellacked), lower surface more dully lustrous, glabrate or persistently stellate-tomentose especially in the

\footnotetext{
13 Quercus duratifolia sp. nov.-Arbor majuscula, ramuli 1-2 mm. crassi sparse stellati vel glabrati, folia sempervirentia supra nitidissima subtus vix lucida 5-10 $\mathrm{cm}$. longa 2-3.5 cm. lata elliptica vel oblanceolata apice rotundata basi cordata vel rotundata integra, venis utrinque 9-15 anastomosantibus leviter prominentibus, petioli 2-5 mm. longi, fructus annuus brevipedunculatus, cupula $12-13 \mathrm{~mm}$. lata $4-6 \mathrm{~mm}$. alta, squamae stricte appressae, glans $12-15 \mathrm{~mm}$. longa ovoidea $1 / 4$ vel $1 / 5$ inclusa, ovula abortiva apicalia.
} 
axils of the principal veins; veins 9 to 15 on each side and often with evanescent intermediates, repeatedly branching and anastomosing, raised above, more prominently so beneath, the reticulum very slightly raised on both surfaces; petioles 2 to $5 \mathrm{~mm}$. long, 1.5 to $2 \mathrm{~mm}$. thick, very dark red in color, from sparsely buff-tomentose glabrate. Staminate catkins 4 to $6 \mathrm{~cm}$. long, moderately closely flowered, nearly glabrous or sparsely puberulent, the apiculate anthers little exserted. Pistillate catkins? Fruit annual, rather small, solitary or paired on a peduncle 4 to 7 or $8 \mathrm{~mm}$. long; cups shallowly cup-shaped to deeply saucer-shaped, 12 or $13 \mathrm{~mm}$. broad, 4 to $6 \mathrm{~mm}$. high, round or flat at base, the scales ovate, broadly rounded, flat and very tightly appressed, puberulent or the apices glabrate and dull brown; acorns 12 to $15 \mathrm{~mm}$. long, 11 to $13 \mathrm{~mm}$. broad, ovoid, obtuse, from minutely puberulent glabrate and light brown, about one-fifth or one-fourth included; abortive ovules apical. (See pls. 66 and 67.)

Range: Mountains of Chiapas, Mexico.

Quercus duratifolia is not very closely related to the other species of the series Aristatae, but even so, in so nondescript a group it is difficult to hit upon distinguishing characters. Its very highly polished upper leaf surface, although only a comparative difference, is probably the most dependable. Its usually cordate leaf bases and larger, flatter mature cups aid in separating it from $Q$. sapotaefolia with which it is most apt to be confused. The usually waxy-glaucous under leaf surface of $Q$. sapotaefolia is diagnostic but not always evident. The acuminate and impressed-veiny leaves of $Q$. hondurensis and $Q$. eugeniaefolia distinguish them adequately.

Specimens examined:

MEXICO.-Chiapas: Mount Ovando, April 5, 1936, Matuda 65, 289, and 857 (Mi); April 9-12, 1937, Matuda 1827 (AA [type], Mi); December 1937, Matuda 2073 (Mi, US, USNA); Matuda 2102 (Mi, USNA); Buena Vista, Escuintla, January 1938, Matuda 1873 (Mi, USNA).

26. Quercus sapotaefolia Liebm., Overs. Danske Vidensk. Selsk. Forhandl. 1854: 185.1854.

Quercus microcarpa Liebm., Overs. Danske Vidensk. Selsk. Forhandl. 1854: 184. 1854. Not Q. microcarpa Lapeyrouse, Hist. Abr. Pl. Pyr. 582. 1813; nor de Morogues, Mem. Soc. Agr. d'Orleans 50: 51.1877.

Q. elliptica $\beta$ microcarpa A. DC. in DC. Prodr. $16^{2}: 71.1864$ (pro parte - as to Guatemala).

Q. guatimalensis A. DC. in DC. Prodr. $16^{2}: 78.1864$ (pro parte - detached fruit of the type only).

Q. parviglans Trel., Proc. Amer. Philos. Soc. 54: 8. 1915.

Q. parviglans f. polycarpa Trel., Mem. Nat. Acad. Sci. 20: 152. pl. 299. 1924.

Q. parviglans f. tejadana Trel., Mem. Nat. Acad. Sci. 20: 152. 1924 (not illustrated).

Q. apanecana Trel., Mem. Nat. Acad. Sci. 20: 152. 1924 (not illustrated).

Q. correpta Trel., Mem. Nat. Acad. Sci. 20: 153. pl. 300. 1924 (pro parte - detached fruit of the type only).

Q. donnell-smithii Trel., Mem. Nat. Acad. Sci. 20: 162. 1924 (pro parte - type only). 
Q. wesmaeli Trel., Mem. Nat. Acad. Sci. 20:172. pl. 344. 1924 (pro parte).

Q. siguatepequeana Trel. in Standley, Journ. Arn. Arb. 11: 25. 1930.

Q. amissaeloba Trel. in Yuncker, Field Mus. Bot. Ser. 17: 357. 1938.

Q. perseaefolia var. achoteana Trel. in Yuncker, Field Mus. Bot. Ser. 17: 357. 1938.

Small to large tree. Twigs 1.5 to $2.5 \mathrm{~mm}$. thick, fluted, glabrous or from loosely tomentose or stellate-pubescent glabrescent or persistently floccose, light brown to dark reddish brown with numerous prominent light lenticels, grayish the second season. Buds about $3 \mathrm{~mm}$. long, $1.5 \mathrm{~mm}$. broad, acute, glabrous or the scales ciliate, reddish brown; the stipules caducous. Leaves evergreen, often persisting through three seasons but sometimes deciduous early in the second, thick and very coriaceous, 4 to usually 8 or often $12 \mathrm{~cm}$. long, 1 to usually 2.5 or even $4 \mathrm{~cm}$. broad, oblanceolate to oblong or elliptic-oblong, often broadest above the middle, narrowly rounded and aristate-tipped to usually broadly or narrowly rounded and not apiculate at apex, cuneate to usually narrowly rounded or broadly rounded or even cordulate at base, entire, the margins rather coarsely revolute and much crisped or sometimes not, upper surface dull to markedly nitid, glabrous, lower surface not bullate, somewhat shining, in age becoming more nitid or usually waxy-glaucous, usually glabrous or with inconspicuous domatia, occasionally rather persistently floccose; veins about 10 to 14 or even 18 on each side, repeatedly branched and obviously anastomosing near the margin, slightly or not at all depressed above, in any event both the principal veins and reticulum slightly raised above, more prominently so beneath; petioles 2 to usually 4 or even $7 \mathrm{~mm}$. long, glabrous or from stellate-pubescent glabrate with the stem. Staminate catkins 5 to $8 \mathrm{~cm}$. long, rather loosely flowered, sparingly short-villous, the apiculate anthers well exserted. Pistillate catkins 1 - to 3 -flowered or rarely 6 - or 8-flowered, subsessile to usually pedunculate, the peduncle 2 to about $20 \mathrm{~mm}$. long (usually under 10). Fruit annual, solitary, paired, or in threes or more, subsessile to usually pedunculate, the peduncle $1 \mathrm{~cm}$. long or less with distal fruit or up to $3 \mathrm{~cm}$. long with more numerous seattered fruit; cups small or moderate, $8 \mathrm{~mm}$. broad and cup-shaped, the scales broadly ovate, very thin and tightly appressed, sparingly sericeous-pubescent or glabrate and light brown and shiny; acorns about $15 \mathrm{~mm}$. long, usually $7 \mathrm{~mm}$. broad, ovate or usually narrowly elliptic, finely sericeouspubescent or glabrate, light brown, about one-fourth included. (See pls. 68 to 70 .)

Range: Chiapas, Guatemala, British Honduras, Honduras, El Salvador, Costa Rica, and Panama (near sea level to usually 1,000 to 2,000 m.); type from Costa Rica (Skinner 6).

Quercus sapotaefolia is relatively constant in all its characters except leaf shape (although the rounded apices are rather dependable). Its rounded leaf apices separate it from Q. eugeniaefolia, which also has veins impressed above. The lack of evident lenticels, usually densely short-velvety-tomentose twigs and petioles, larger and characteristically acuminate cordate and impressed-veiny leaves of $Q$. hondurensis may be depended upon to distinguish that species from Q. sapotaefolia.

The various species, varieties, and forms described by Liebmann and 
Trelease and here treated as synonyms are almost without exception based upon variations in leaf size and shape which may occur indiscriminately almost anywhere in the range of the species. Only $Q$. parviglans f. polycarpa is based on any other character, and its several fruits scattered on a larger peduncle constitute a tendency noted variously in the species. The narrow-leafed form described as $Q$. parviglans $\mathrm{f}$. tejadana and as Q. apanecana seems to be confined to El Salvador, but one specimen (Calderon 2443 in the Arnold Arboretum Herbarium) exhibits both narrow and broad leaves. Q. amissaeloba is apparently based upon a juvenile form or a stump-sprout, for the type collection has scarcely two leaves of the same size and shape.

The specimen cited by Trelease as the type of $Q$. donnell-smithii (Smith 1967) is obviously Q. sapotaefolia, but the illustration, which is said to be made from that number, is clearly Smith 2629, a specimen of Q. acatenangensis. The description also is undoubtedly based upon the latter number. This is discussed further under Q. acatenangensis.

A part of the material referred by Trelease to Q. wesmaeli (Pittier 2086) is composed of juvenile specimens one of which is accompanied by several old leaves and is unquestionably to be referred to $Q$. sapotaefolia. The type (Pittier 773) was collected in the same locality. It has not been examined, but judging by the excellent photograph in Trelease's illustration ( $p l$. 344), it can scarcely be excluded from Q. sapotaefolia. The other specimen illustrated on the same plate (Tonduz 11827) must be referred to Q. borucasana.

\section{Specimens examined:}

MEXICO.-ChIAPAs: Fenia, May-June 1925, Purpus 97 (US); Purpus 416 (US); Santa Rosa, near Escuintla, June 20, 1941, Matuda 4232 (USNA).

BRITISH HONDURAS.-Near Guatemala boundary, January 17, 1930 , Schipp 663 (AA, F, MBG, Mi, NY); "Agri. Station," November 14, 1936, Kelly $163(\mathrm{~F})$.

GUATEMALA.-Without locality, May 1927, Morales 748 (US). Dept. SAN MARCos: Volcan Tacana above Sibinal, February 20, 1940, Steyermark 36161 (F, USNA). Dept. Quiche: Nebaj, December 10, 1934, Skutch 1906 (AA, F, Ill). Dept. Alta Verapaz: Samac, April 1889, Smith 1710 (US); near Coban, March 26-April 15, 1939, Standley 69127 (F, USNA); near San Cristobal, April 9, 1939, Standley 71001 (F, USNA). Dept. BaJa Verapaz: near Purulha, January 20, 1905, Maxon and Hay 3372 (US); near Salama, June 1904, Cook 236 (US); vicinity of Patal, March 30, 1939, Standley 69560 (F); north of Santa Rosa, March 30, 1939, Standley 69818 and 69895 (F, USNA). Dept. Guatemala: near Guatemala, July 1860, Hayes without number (G [3]); November 11, 1916, Popenoe 726 (US, USNA); Eureka, near Guatemala, April 2, 1915, Trelease 55 (Ill); hills between Guatemala and San Raimundo, January 18, 1939, Standley 62940, 62948, 63001, 63013, and 63015 (F, USNA); near San Juan Sacatepequez, December 8, 1938, Standley 59233 and 59235 (F, USNA); Finca La Aurora, 1940, Aguilar 424 (F); Sapote, March 1890, Smith 1967 (G, NY, US [type number of Q. donnellsmithii but not the plant described and illustrated]). DEPT. JaLAPA: Volcan Jumay, January 8, 1908, Kellerman 7707 (F); Cerro Alcoba, east of Jalapa, December 2, 1939, Steyermark 32572, 32594, and 32596 (F, USNA); vicinity of Jalapa, November 7-18, 1940, Standley 76747 (USNA); between Jalapa and Paraiso, November 14, 1940, Standley 77324 (USNA); Montaña Miramundo above Miramundo, between Jalapa and Mataquescintla, December 5, 1939, Steyermark 32733 (F, USNA); Montaña Durazno, 2 miles east of San Pedro Pinula, December 10, 1939, Steyermark 33000 (F, USNA).

EL SALVADOR.-Dept. Chalatenango: El Jute, 1928, Calderon 2443 (AA, $\mathrm{F}, \mathrm{US})$; Calderon 2447 (F [mixed with $Q$. hondurensis]).

HONDURAS.- Dept. ComaYagda: about El Achote above Siguatepeque, July 28, 1936, Yuncker, Dawson, and Youse 6203 (DeP, F, MBG, Mi, US); August 7, 1936, Yuncker, Dawson and Youse 6379 (DeP, F, MBG, Mi, NY, US' [isotypes of Q. amissaeloba]); February 18, 1928, Standley 56179 (AA, F, US); vicinity of Siguatepeque, February 14-27, 1928, Standley 56364 (AA, F, US); 
Standley 56393 (AA, F [type of Q. siguatepequeana]). Dept. Tegucigalpa: Mont. de la Flor near Tegucigalpa, December 13, 1937, von Hagen 1220 (F, NY). COSTA RICA.-Prov. San Jose: hills about Santa Maria, April 20, 1928, Stork 1500 (F). Prov. Alajuela: Volcan Poas, March 31, 1907, Pittier 2036 (NY, US).

27. Quercus eugeniaefolia Liebm., Overs. Danske Vidensk. Selsk. Forhandl. 1854: 185.1854.

Quercus bumelioides Liebm., Overs. Danske Vidensk. Selsk. Forhandl. 1854: 188 . 1854 .

Q. eugeniaefolia f. petiolata Trel., Mem. Nat. Acad. Sci. 20: 161. pl. 316. 1924.

Small or large tree, reaching $30 \mathrm{~m}$. Twigs 1.5 to $2.5 \mathrm{~mm}$. thick, fluted, from sparsely loose-tomentose soon glabrate and glossy reddish brown with rather prominent lenticels the second year. Buds 3 to $4 \mathrm{~mm}$. long, fusiform, very acute, scales fulvous-ciliate about the apex or glabrate, dull brown; the ligulate stipules early caducous. Leaves subevergreen or distinctly evergreen, normally thick, in any event quite hard and leathery, 6 to usually 9 or even $15 \mathrm{~cm}$. long, 1.5 to $3.5 \mathrm{~cm}$. broad, linear-lanceolate to narrowly subelliptic, apex normally acuminate and aristate-tipped, sometimes long-acuminate or merely acute or even individually rounded, base cuneate or attenuately acute to rounded, entire, margins rather coarsely revolute (in fully matured leaves) and usually finely crisped, upper surface glossy and glabrous or minutely stellate-pubescent at the base of the midrib, lower surface glabrous or the midrib sparsely stellate-pubescent toward the base, the lamina dull and often waxy-glaucous in age; veins about 12 to 15 on each side and often with evanescent intermediates, issuing at an angle of about 75 or 80 degrees, repeatedly branched and anastomosing near the margin, impressed above but somewhat raised within the grooves, more prominently raised beneath, the reticulum very slightly raised on both surfaces; petioles 2 to 5 or even $7 \mathrm{~mm}$. long, rather distinctly winged, glabrate or sparsely stellate-pubescent for a time. Staminate catkins about $4 \mathrm{~cm}$. long, loosely flowered, sparsely crisped-villous. Pistillate catkins? Fruit annual, small, solitary on glabrous peduncles 3 to $8 \mathrm{~mm}$. long; cups about 7 to $11 \mathrm{~mm}$. broad, about $5 \mathrm{~mm}$. deep, cup-shaped or shallower, rounded or slightly constricted at the base, scales ovate, broadly rounded, very closely appressed, sericeous-puberulent except the glabrous brown apex and margins; acorns 10 or $11 \mathrm{~mm}$. long, 9 or $10 \mathrm{~mm}$. broad (much smaller and more slender with narrower cups in younger fruit which often appears fully grown), ovoid to subrotund, fulvous-sericeous-puberulent, light brown where abraded, about one-fifth or one-fourth included; abortive ovules apical. (See pls. 71 and 72.)

Range: Mountains of central Costa Rica to upper Panama $(1,400$ to $2,400 \mathrm{~m}$.) ; type from Costa Rica (von Warscewicz $C$ ) without further data.

Trelease regarded $Q$. eugeniaefolia as related to $Q$. seemanni from which it is often difficult to distinguish but to which it is not closely related. It is distinguished from $Q$. seemanni by its prominently revolute leaves with veins issuing at an angle of 75 or 80 degrees (although this broad angle is rarely seen in very narrow leaves in Q. seemanni) and its abortive ovules strictly apical. Q. eugeniaefolia is probably most closely related to $Q$. sapotaefolia from which it is 
distinguished by its characteristically acuminate and aristate-tipped leaves. From Q. hondurensis, which also has acuminate leaves, Q. eugeniaefolia may be separated by its smaller.leaves and glabrate twigs.

Specimens examined:

COSTA RICA.-Prov. Alajuela: Palmira, region of Zarcero, February 24, 1938, A. Smith 198 (F); A. Smith 370 (F, MBG); Cerro Palmira, June 23, 1941, A. Smith 2828 (USNA); Palmira, July 1, 1941, A. Smith 2877 (USNA). Prov. Heredia: Cerros de Zurqui, northeast of San Isidro, March 3, 1926, Standley and Valerio 50588 (F, US); Standley and Valerio 50707 (US). Prov. SAN Jose: between Aserri and Tarbaca, February 12, 1924, Standley 34181 (US); vicinity of Santa Maria de Dota, December 14-26, 1925, Standley 41611 (F, US); Laguna de la Chonta, northeast of Santa Maria de Dota, December 18, 1925, Standley 42220 (F, US); near Quebradillas, north of Santa Maria de Dota, December 24, 1925, Standley 42876,42988 , and 43046 (F, US). Prov. Cartago: El Muñeco on Rio Navarro, March 6-7, 1926, Standley and Torres 50921 (F, US); Cuesta de Tarrazu, April 1893, Tonduz 7871 (US [3] [a mixed collection; another duplicate is $Q$. corrugata]); near Agua Caliente, February 26, 1928, Stork 1042 (F); Cerro Jucosal, March 3, 1928, Stork 1130 (F); Santa Clara Hills, June 16, 1928, Stork 2591 (F); El Tablazo, April 1932, Valerio 179 (F).

PANAMA.- Prov. Chiriqui: Casita Alta, Volcan Chiriqui, June 28-July 2, 1938, Woodson, Allen, and Seibert 868 (USNA); between Finca Lerida and Peña Blanca, July 9, 1940, Woodson and Schery 318 (USNA).

Series Borucasanae Trel., Mem. Nat. Acad. Sci. 20: 160.1924.

Series Benthamiae Trel., Mem. Nat. Acad. Sci. 20: 146. 1924 (pro parte- not the type).

Series Consociatae Trel., Mem. Nat. Acad. Sci. 20: 172. 1924 (pro parte - not the type).

Trees (?); twigs rather slender, glabrate; buds 1 to $3 \mathrm{~mm}$. long, sparsely pubescent or glabrate; leaves evergreen or subevergreen, thick and hard, rather small, elliptic or oblong, acute at both ends or the base obtuse, entire, glabrate or sparingly pubescent in sheltered spots; petioles less than $1 \mathrm{~cm}$. long, winged; fruit annual, mediumsized or small, short-peduncled; the cups at most deeply saucer-shaped; acorns ovoid, one-fourth or less included; abortive ovules apical.

Range: Mountains of Costa Rica.

Includes: Q. borucasana Trel. (type) and Q. tonduzii Seemen.

28. Quercus borucasana Trel., Mem. Nat. Acad. Sci. 20:161. pl.315. 1924.

Quercus granulata Liebm., Overs. Danske Vidensk. Selsk. Forhandl. 1854: 186. 1854. Not Q. granulata Raf., Alsog. Amer. 21. 1838.

Q. pittieri Wesmael ex Seemen, Bul. Herb. Boissier 2. ser. 4: 652. 1904 (nom. nud.).

Q. wesmaeli Trel., Mem. Nat. Acad. Sci. 20: 172. pl. 344. 1924 (pro max. parte).

Probably a small tree. Twigs 1.5 to $2.5 \mathrm{~mm}$. thick, fluted, glabrate and dark reddish brown with few large but inconspicuous lenticels, becoming gray the second season. Buds 1.5 to $2 \mathrm{~mm}$. long, ovoid or round, obtuse, glabrous and dark brown; the stipules caducous. Leaves deciduous(?), thick and rather hard, about 3 to $7 \mathrm{~cm}$. long, 1.2 .5 to $1.75 \mathrm{~cm}$. broad, elliptic or oblong to narrowly lanceolate, apex acute and usually aristate-tipped, base cuneate, entire, margins slightly thickened but scarcely revolute, seldom crisped, both sur- 
faces glabrate and somewhat lustrous, smooth (the type of Q. granulata described as "granular-bullate above"); veins 10 or 12 on each side with strong or evanescent intermediates, repeatedly branching and anastomosing toward the margin, very slightly if at all raised above, more prominent beneath, the reticulum scarcely raised above and only minutely so beneath; petioles 4 to $7 \mathrm{~mm}$. long, prominently winged. Catkins? Fruit annual, rather small, solitary or paired on a peduncle 2 to $5 \mathrm{~mm}$. long; cups 10 to $15 \mathrm{~mm}$. broad, 4 to $5 \mathrm{~mm}$. high, hemispheric or shallower, round or somewhat constricted at the base, scales ovate, the narrowed apex rounded, closely appressed, from puberulent glabrate and rather dull brown; acorns 10 to $15 \mathrm{~mm}$. long, 9 to $13 \mathrm{~mm}$. broad, ovoid, about one-fifth or less included; abortive ovules apical. (See pls. 73 and 74.)

Range: Mountains of Costa Rica $(1,800 \mathrm{~m}$.$) ; type from Volcan$ Irazu (Oersted 5-3491).

Quercus borucasana has somewhat the appearance of Q. eugeniaefolia in miniature, but its perfectly flat leaf margin adequately distinguishes it from that species as well as from Q. tonduzii. From the latter species it also differs in having smaller leaves and shorter glabrate buds as well as smaller fruit.

Specimens examined:

COSTA RICA.- Prov. Alajuela: Santiago de San Ramon (Calera, Rio Jesus), February 25, 1929, Brenes 6704 (F). Prov. San Jose: Cerro del Roble, Copey, April 1898, Tonduz, 11827 (US [isotype of Q. wesmaeli]). Prov. PunTARenas: Cuesta de las Borucas, January 1897, Pittier 10553 (US).

29. Quercus tonduzii Seemen, Bul. Herb. Boissier 2. ser. 4: 656. 1904.

Probably a large tree. Twigs 1.5 to $2.5 \mathrm{~mm}$. thick, coarsely fluted, glabrate and brown or gray with few large raised but inconspicuous lenticels. Buds about 3 or $4 \mathrm{~mm}$. long, ovoid or subfusiform, pubescent about the apex, light brown or buff; the stipules caducous. Leaves evergreen, thick and rather hard, 5 to usually 7 or $9 \mathrm{~cm}$. long, 2 to 3 or $3.5 \mathrm{~cm}$. broad, narrowly elliptic or oblong to oblanceolate, apex short-acuminate, base narrowly cuneate to obtusely cuneate, entire, margins rather prominently thickened and revolute, crisped, upper surface glabrous and shiny, lower surface glabrous or with scant tufts of stellate hairs in the axils of the veins, rather dull; veins about 9 to 11 on each side and with evanescent intermediates, repeatedly branching and anastomosing toward the margin, very slightly impressed and raised within the grooves above, rather prominent beneath, the reticulum minutely raised above, slightly more prominent beneath; petioles 4 to $10 \mathrm{~mm}$. long, rather prominently winged, from sparsely pubescent becoming glabrate and very dark reddish brown or black. Catkins? Fruit annual, medium-sized, solitary or paired on a peduncle up to $10 \mathrm{~mm}$. long and $4 \mathrm{~mm}$. thick; cups about 14 to $18 \mathrm{~mm}$. broad, 7 or $8 \mathrm{~mm}$. high, goblet-shaped, the base somewhat constricted, scales lance-ovate, the much narrowed apex rounded and rather loosely appressed, sparsely pubescent or the apex glabrate and shiny light brown; acorns about $18 \mathrm{~mm}$. long, $18 \mathrm{~mm}$. broad, ovoid or round but finally small-pointed, glabrate and light brown, abortive ovules apical. (See pl. 75.)

Range: Mountains of central Costa Rica $(2,200 \mathrm{~m}$.). 
Quercus tonduzii is distinguished from $Q$. borucasana in the discussion under that species. From Q. eugeniaefolia, to which it is not closely related but which it most confusingly resembles, it may be separated by its veins which issue at an angle of about 45 degrees, its larger acorns, and its rather loosely appressed cup scales.

Neither Q. borucasana nor Q. tonduzii is clearly understood. The former is known from three rather fragmentary collections and the latter from a single but complete collection. This is not enough to establish the amount of intraspecific variation or the dependability of the characters in this rather difficult group of species.

Specimens examined:

COSTA RICA.-Prov. Alajuela: Volcan Poas, Achiote, November 1896, Tonduz 10788 (US [2] [isotypes]).

Series Rapurahuenses Trel., Mem. Nat. Acad. Sci. 20: 143.1924.

Series Citrifoliae Trel., Mem. Nat. Acad. Sci. 20: 147. 1924.

Small or large trees; twigs slender, glabrate, buds 2 to $4 \mathrm{~mm}$. long, ovoid, glabrate; leaves evergreen or deciduous, rather small, lanceolate, often long-acuminate, entire; petioles rather short; fruit annual, rather small or medium-sized, cups cup-shaped or saucer-shaped, the scales appressed, acorn usually covered at base only; abortive ovules basal, lateral, or apical.

Range: Costa Rica and upper Panama.

Includes: Q. seemanni Liebm. (including Q. rapurahuensis Pittier, the type of the series), and Q. gulielmi-treleasei C. H. Mull.

This series is made up of moderate-sized, entire-leaved, annualfruited species with short petioles and acute or acuminate leaf apices. It is characterized by appressed cup scales and rather small fruit. Its relationship to other series is not clear except insofar as its entire leaves and basal abortive ovules suggest the series Andinae and Costaricenses, and from these its closely appressed cup scales clearly distinguish it. The series Aristatae is more difficult to distinguish, but its distinctness is indicated by its even smaller leaves and fruit and its cup scales exceedingly closely appressed and abortive ovules apical.

30. Quercus seemanni Liebm., Overs. Danske Vidensk. Selsk. Forhandl. 1854: 188 . 1854

Quercus citrifolia Liebm., Overs. Danske Vidensk. Selsk. Forhandl. 1854: 187.1854.

Q. salicifolia var. seemanni Wenzig, Jahrb. K. Bot. Gart. Berlin 3: 207.1884.

Q. rapurahuensis Pittier ex Seemen, Bul. Herb. Boissier 2. ser. 4: 654. 1904 (nom. nud.); ex Trelease, Mem. Nat. Acad. Sci. 20: 143. pl. 275. 1924 (description).

Q. boquetensis Standl., Field Mus. Bot. Ser. 22: 13.1940.

Q. chiriquiensis Trel., in Herb.

Small or moderately large tree. Twigs 1 to $2.5 \mathrm{~mm}$. thick, fluted, from sparsely pubescent soon glabrate and dark reddish brown with prominent light lenticels. Buds 2 to $4 \mathrm{~mm}$. long, ovoid or elongating, acute, glabrous, light brown; the ligulate stipules soon caducous. Leaves subevergreen, thin but rather hard, 4 to usually 8 or even 16 $\mathrm{cm}$. long, 1 to usually 3 or $4 \mathrm{~cm}$. broad, lanceolate or occasionally 
linear-lanceolate or ovate-lanceolate or elliptic, apex long- or short, acuminate, base rounded to usually cuneate or attenuately acuteentire, margins minutely revolute, usually finely crisped, upper surface glabrate and shiny, lower surface glabrate or persistently tomentose along the midrib, dull; veins 8 to usually 10 or 12 on each side, repeatedly branching but obscurely anastomosing near the margin, very slightly or rather clearly raised above, or slightly impressed, somewhat more prominent beneath, the reticulum slightly raised on both surfaces; petioles 5 to usually 10 or rarely even $17 \mathrm{~mm}$. long, rather prominently winged, glabrate. Staminate catkins 4 or $5 \mathrm{~cm}$. long, rather loosely flowered, sparsely crisped-villous, the apiculate anthers slightly exserted. Pistillate catkins about $1 \mathrm{~cm}$. long, 2- to 4flowered along a slender glabrate peduncle. Fruit annual, rather small, solitary or paired on a peduncle 2 to $10 \mathrm{~mm}$. long and as much as $3 \mathrm{~mm}$. thick; cups goblet-shaped or deeper, 12 to $14 \mathrm{~mm}$. broad, about 5 to $10 \mathrm{~mm}$. high, the scales triangular-ovate, apices rounded, appressed, minutely sericeous-puberulent but the apices and margins glabrate and glossy brown; acorns about 12 to $15 \mathrm{~mm}$. long, 11 or 12 $\mathrm{mm}$. broad, subrotund to ovoid, loosely buff-puberulent, light brown where abraded, about one-fourth or one-third included; abortive ovules basal or lateral to subapical. (See pls. 76 to 78.)

Range: Mountains of central Costa Rica to upper Panama $(1,000$ to $2,400 \mathrm{~m}$.).

Quercus seemanni differs from the other species of the series in its moderately petioled, relatively small leaves with long-acuminate apices. Q. rapurahuensis differs to no appreciable degree. The name $Q$. chiriquiensis is ascribed to Trelease in several herbaria, although it has never been published.

Specimens examined:

COSTA RICA.-Prov. Alajuela: Palmira, near Zarcero, October 1, 1937, A. Smith 464 (F, MBG, USNA). Prov. Heredia: Quebradas above San Isidro, July 5, 1932, Stork 3181 (F). Prov. SAN Jose: about Santa Maria, May 4, 1928, Stork 1745 (F); May 27, 1928, Stork 2420 (F); San Lorenzo de Dota, March 4, 1890, Pittier 2262 (US); Copey, Feb. 1898, Tonduz 11697 (US); March 1898, Tonduz 11795 (NY [2], US [3] [isotypes of Q. rapurahuensis]); Santa Rosa de Copey, April 1898, Tonduz 12231 (US [2]); El Copey, Tarrazu, March 1918, Jimenez 1086 (US); near Finca La Cima, above Los Lotes, north of Copey, December 21-22, 1925, Standley 42558 (US); near Quebradillas, north of Santa Maria de Dota, December 24, 1925, Standley 42985 (US).

PANAMA.-Prov. Chiriqui: labeled "Veraguas" and without locality or date, Seemann without number (G, NY [isotypes]); Cerro Vaca, eastern Chiriqui, December 25-28, 1911, Pittier 5305 (F, G, NY, US); Distr. Boquete, Volcan Chiriqui, July 12, 1938, Davidson 909 (F); vicinity of Casita Alta, Volcan Chiriqui, June 28-July 2, 1938, Woodson, Allen, and Seibert 796 (NY, USNA); Camiseta, Volcan Chiriqui, February 13, 1940, Terry 1337 !(MBG); Boquete, May 20, 1938, Davidson 677 (F); June 26, 1938, Davidson 780 (F [type of Q. boquetensis]); Salto Boquete, January 8, 1939, Terry 1258 (F, MBG); Bajo Chorro, March 25, 1938, Davidson 437 (F, MBG); March 4, 1938, Davidson 721 (F); upper valley of Rio Chiriqui Viejo, between Paso Ancho and Monte Lirio, January 16, 1939, Allen 1595 (USNA).

\section{Quercus gulielmi-treleasei sp. nov. ${ }^{14}$}

\section{Quercus chiriquina Trel., in herb.}

Large tree. Twigs 1.5 to $3 \mathrm{~mm}$. thick, fluted, from fulvous-stellatetomentose becoming glabrate or sparsely floccose, reddish brown with

14 Quercus gulielmi-treleasei sp. nov.-Arbor grandis, ramuli 1.5-3 mm. crassi glabrati, folia decidua (?) $18-25 \mathrm{~cm}$. longa lanceolata longe acuminata glabra vel costa subtus stellata excepta, venis utrinque 18-20 ramosis et anastomosantibus utrinque prominentibus, petioli $2-4 \mathrm{~mm}$. longi alati, fructus annuus (?) pedunculatus, cupula $13-18 \mathrm{~mm}$. lata, squamae appressae, glans hemispherica vel ovata $1 / 5 \mathrm{vel}$ omnino inclusa, ovula abortiva basalia. 
rather prominent pale lenticels, becoming gray. Buds about $2 \mathrm{~mm}$. long, round to narrowly ovate, obtuse, straw-colored, glabrous or the scales minutely ciliate, the ligulate stipules early caducous. Leaves deciduous (?), thin but firm and coriaceous, 8 to usually 18 or even $25 \mathrm{~cm}$. long, 2 to usually 5 or sometimes $7 \mathrm{~cm}$. broad, narrowly or broadly lanceolate to oblanceolate, apex narrowly acute to longacuminate, not strikingly aristate-tipped, base cuneate to very narrowly rounded, entire, margins minutely revolute and very finely crisped, upper surface glabrous and shiny, lower surface glabrous or usually sparsely stellate-pubescent along the midrib toward the base, somewhat shining; veins about 15 to 18 or 20 on each side with evanescent intermediates, repeatedly branching and inconspicuously anastomosing near the margin, very slightly impressed above but raised within the grooves, rather prominent beneath, the fine reticulum somewhat raised on both surfaces; petioles 2 to $4 \mathrm{~mm}$. long, as much as $2 \mathrm{~mm}$. thick, winged, glabrate or pubescent like the twig, dark reddish brown at the swollen base. Catkins? Fruit probably annual, solitary or paired or several scattered on a peduncle 1 to 2 or $4 \mathrm{~cm}$. long, 1.5 to $3 \mathrm{~mm}$. thick, often irregularly bent in a zigzag at the points of attachment of the cups, glabrate, reddish brown with conspicuous lenticels; cups 13 to $18 \mathrm{~mm}$. broad, 5 to $10 \mathrm{~mm}$. high, deeply saucershaped to goblet-shaped, often somewhat constricted at the base, the scales broadly triangular-ovate, rounded at apex, thin and very closely appressed, the base sometimes appearing thickened but merely protruded by the bud in its axil, finely buff-sericeous but the apices and margins glabrate; acorns 7 to $15 \mathrm{~mm}$. long, 11 to $15 \mathrm{~mm}$. broad, hemispheric to broadly ovate, apex nearly flat or rounded, from minutely sericeous-puberulent tardily glabrate, one-fifth included to completely covered (in equally mature material, varying with the form of the acorn) ; abortive ovules basal. (See pls. 79 and 80.)

Range: Wet forests of upper Panama and Costa Rica (1,300 to $1,900 \mathrm{~m}$.).

Quercus gulielmi-treleasei differs from the other entire-leaved shortpetioled species of Erythrobalanus by its small, pedunculate fruit and large leaves or by its very long-acuminate leaf apices and very short petioles. It is apparently only remotely related to $Q$. seemanni, its closest ally, but aside from the larger leaves, very short petioles, and rather longer-stalked, smaller fruit of Q. gulielmi-treleasei, distinguishing characters are difficult to ascertain.

It seemed advisable not to employ Trelease's herbarium name, $Q$. chiriquina, for this species because of the similarity of the name to $Q$. chiriquiensis, another herbarium name of long standing which has even recently been used to designate $Q$. seemanni. As this new species is very similar to $Q$. seemanni, it would have been particularly confusing to validate Trelease's name, and therefore it is proposed to honor him by naming for him a species which he has recognized as distinct in a genus with which he is so closely identified.

Specimens examined:

COSTA RICA.- Prov. Cartago: El Muñeco, on Rio Navarro south of Navarro, February 8-9, 1924, Standley 33875 (F, US); March 6-7, 1926, Standley and Torres 51223 (F, US); Standley and Valerio 51382 (F, US).

PANAMA.-Prov. Chiriqui: valley of upper Rio Chiriqui Viejo, vicinity of Monte Lirio, June 27-July 13, 1935, Seibert 226 (MBG [type]); between Boquete and Finca Lerida, April 4, 1937, Allen 302 (Ill, MBG, USNA). 
Series Crispifoliae Trel., Mem. Nat. Acad. Sci. 20: 146.1924.

Series Pachyphyllae Trel., Mem. Nat. Acad. Sci. 20: 147. 1924.

Medium-sized or large trees; twigs from fulvous-stellate glabrate; buds oblong-fusiform, the scales fulvous-ciliate; leaves deciduous (?) to obviously evergreen, rather large, oblanceolate to linear-lanceolate, long-acuminate, glabrous except the base of the midrib, veins much branched and anastomosing, raised on both surfaces; petioles 5 to rarely $10 \mathrm{~mm}$. long; fruit biennial (?), large, cups and attachment unknown, acorns ovoid, 25 to $30 \mathrm{~mm}$. long, included at the base only.

Range: Southern Guatemala and adjacent Chiapas and El Salvador.

Includes: Q. crispifolia Trel. (type).

The relationship of this series is discussed under the following species.

32. Quercus crispifolia Trel., Mem. Nat. Acad. Sci. 20: 147. pl. 286. 1924.

Quercus amphioxys Trel., Mem. Nat. Acad. Sci. 20: 141. pl. 268. 1924.

Q. incrassata Trel., Mem. Nat. Acad. Sci. 20: 147. pl. $28 \%$. 1924.

Medium-sized or large tree. Twigs 1 to 2 or $3 \mathrm{~mm}$. thick, fluted, from loosely fulvous-stellate-tomentose promptly or tardily glabrate and grayish or reddish brown with prominent or inconspicuous lenticels. Buds 5 or $6 \mathrm{~mm}$. long, oblong-fusiform, acute, light brown and glabrous except for the moderately fulvous-ciliate scales; the stipules promptly caducous, $5 \mathrm{~mm}$. long, ligulate, tomentose. Leares deciduous (?) or obviously evergreen, thin but hard and coriaceous or rather thick, 10 to usually 15 or 20 or rarely $25 \mathrm{~cm}$. long, 3 to usually 5 or even $7.5 \mathrm{~cm}$. broad, oblanceolate to linear-lanceolate, the apex acuminate to attenuately narrowed or flagellate, inconspicuously aristatetipped, the base attenuately narrowed and decurrent on the petiole to merely cuneate or narrowly rounded, rarely cordate, entire, margins minutely revolute, finely crisped, upper surface somewhat shining, glabrous or fulvous-stellate-pubescent at the base of the midrib, lower surface similar, usually somewhat more prominently stellate-pubescent along the base of the midrib; veins about 15 to 20 on each side with occasional evanescent intermediates, repeatedly branched and clearly but rather inconspicuously anastomosing near the margin, slightly impressed above but raised within the grooves, rather prominent beneath, the rather fine reticulum slightly raised on both surfaces; petioles 5 to rarely $10 \mathrm{~mm}$. long, 1.5 to $2.5 \mathrm{~mm}$. thick at the swollen dark-red base, from loosely fulvous-tomentose glabrate. Catkins? Fruit biennial (?); cups and attachment unknown; acorns rather large, broadly ovoid, 25 to $30 \mathrm{~mm}$. long, 22 to $26 \mathrm{~mm}$. broad, from minutely silky-puberulent glabrate and brown, included at the base only. (See pls. 81 to 84 .)

Range: Wet mountains of southwestern and southeastern Guatemala and adjacent Chiapas, Mexico (1,500 to 2,700 m.), and probably El Salvador.

Quercus crispifolia differs from the other entire-leaved species of Erythrobalanus in its very short petioles, elongate buds, and very large fruit. Some of the other species have one or another of these characters but are then clearly excluded by the others. In none is 
the apical acuminate drip-tip so well developed as in this species. Q. gulielmi-treleasei, another short-petioled and long-acuminate species, is the only one which closely resembles Q. crispifolia in leaf outline. It differs in having comparatively small fruit, the acorns about $1 \mathrm{~cm}$. broad. Q. incrassata is based solely upon a variation in the form and thickness of the leaves and cannot be held distinct. It is unfortunate that both $Q$. crispifolia and $Q$. incrassata were described from only detached leaves and acorns without cups. This adds considerably to the difficulty of disposing of the species satisfactorily

Without knowledge of the fruition or of the nature of the cup it is difficult to assign a relationship to Q. crispifolia. The vegetative characters (especially the leaves and buds) and the large size of the acorn rather suggest a relationship to $Q$. humboldtii, but that cannot be satisfactorily demonstrated.

Specimens examined:

MEXICO.-Chiapas: Tapachula, 1918, Reeves 4 (Ill [type]); Reeves 7 (Ill [type of Q. incrassata]).

GUATEMALA.-Dept. San Marcos: above Barranea Eminencia, March 14, 1939, Standley 68564 (F, USNA). Dept. Alta Verapaz: south of Tactic, March 30, 1939, Standley 69935 (F, USNA); about Chelac, northeast of Charcha, April 2, 1939, Standley 70383 (F, USNA). Dept. Jalapa: Montaña Miramundo between Miramundo and Buena Vista, December 6, 1939, Steyermark 32813 (F [2]). Dept. Chiquimula: about El Barriol, upper slopes of Montaña Tajuran, October 28, 1939, Steyermark 30808 (F).

Series Castaneae Trel., Mem. Nat. Acad. Sci. 20: 178.1924.

Series Tristes Trel., Mem. Nat. Acad. Sci. 20: 171. 1924.

Series Consociatae Trel., Mem. Nat. Acad. Sci. 20: 172. 1924 (pro parte - the type species only).

Small or large trees; twigs slender, from tomentose glabrate; buds ovoid to conic; leaves deciduous or remaining until the new growth appears, medium-sized or small, oblong to narrowly obovate, subentire or aristately low-toothed especially above the middle, upper surface glabrate, shiny, and impressed-veiny, lower surface glabrate or persistently tomentose, prominently reticulate-veiny, dull, prominently bullate-granular; petioles short or moderately long; fruit annual, small, the cup scales closely appressed, rounded at apex, canescent or glabrate.

Range: Central Mexico to Guatemala and El Salvador.

Includes: Q. tristis Liebm. and a few Mexican species of which $Q$. castanea Nee is the type.

There seems to be no justification for maintaining a separate series for the Guatemalan plants as opposed to the Mexican. The annual fruit with small cups and appressed scales, the subevergreen impressedveiny leaves, often aristate-toothed and always bullate-granular beneath, seem to constitute basic characters worthy of serial rank, but to have them appear in each of several series with essentially no supporting differences seems misleading.

33. Quercus tristis Liebm., Overs. Danske Vidensk. Selsk. Forhandl. 1854:174. 1854. Not Q.tristis Gand., Fl. Europ. 21: 34. 1890.

Q. castanea A. DC. in DC. Prodr. 16 $6^{2}: 72.1864$ (pro parteGuatemalan material only). Not Q. castanea Nee, Anal. Cienc. Nat. 3: 276. 1801; nor Mühlenberg, Neue Schr. Gesellsch. Naturf. Fr. 3: 396. 1801. 
Q. castanea $\beta$ sublobata A. DC. in DC. Prodr. 16 ${ }^{2}: 72.1864$.

Q. tristis f. sublobata Trel., Mem. Nat. Acad. Sci. 20: 171. pl. 343. 1924.

Q. tristis f. niederleini Trel., Mem. Nat. Acad. Sci. 20: 171. pl. 343. 1924.

Q. tristis f. vulcani Trel., Mem. Nat. Acad. Sci. 20: 172. pl. 342. 1924.

Q. tristis f. mixcoensis Trel., Mem. Nat. Acad. Sci. 20: 172. 1924 (not illustrated).

Q. scherzeri Trel., Mem. Nat. Acad. Sci. 20: 172.pl. 343.1924. Q. consociata Trel., Mem. Nat. Acad. Sci. 20: 172. pl.345. 1924.

Medium-sized or large tree. Twigs 1 to usually 2 or $2.5 \mathrm{~mm}$. thick, Hluted, brown or reddish brown with scarcely evident or rarely prominent lenticels, from sparsely stellate-tomentose soon glabrate or sometimes rather persistently pubescent. Buds about $4 \mathrm{~mm}$. long, ovoid to conic, acute, from pubescent nearly glabrate, light or dark brown; the ligulate stipules early caducous, about $5 \mathrm{~mm}$. long, dorsally pubescent. Leaves subevergreen, persisting until the appearance of new growth or often not, thin but very hard and coriaceous, about 3 to usually 6 or often $12 \mathrm{~cm}$. long, 1 to usually 2.5 or even $5 \mathrm{~cm}$. broad, characteristically oblong or very narrowly obovate-elliptic, almost always broadest above the middle, acute to broadly rounded and usually apiculate or aristate-tipped at apex, subcuneate to rounded or usually cordate at the base, subentire to characteristically low-aristatetoothed or coarsely toothed with aristate tips, especially toward the apex, margins cartilaginous-revolute, minutely crisped, upper surface glabrate or somewhat pubescent about the base of the midrib, somewhat shiny, prominently impressed-veiny, lower surface from stellatetomentose glabrate or rather floccose along the midrib and principal veins, dull or opaque, prominently raised-reticulate-veiny, the surface prominently bullate-granular or in young foliage low-bullate; veins 10 or 12 on each side, branching and obviously anastomosing near the margin, with the reticulum rather evidently impressed above and quite prominent beneath, the tertiaries rather strikingly regular and ladderlike; petioles 2 to 5 or even $15 \mathrm{~mm}$. long (the shortest on juvenile forms with coarsely toothed leaves), glabrate. Staminate catkins 5 or $6 \mathrm{~cm}$. long, loosely flowered, the rachis short-stellate-pubescent, the anthers well exserted. Pistillate catkins very short-pedunculate, 1or 2 -flowered. Fruit annual, subsessile or the peduncle $5 \mathrm{~mm}$. long, solitary or paired; cups 10 to $15 \mathrm{~mm}$. broad, shallowly goblet-shaped or cup-shaped, the scales ovate to triangular, the apices rounded, very closely appressed, canescent or eventually nearly glabrate and glossy, light brown; acorns 12 to $15 \mathrm{~mm}$. long, 10 to $12 \mathrm{~mm}$. broad, ovaterounded, very obtuse, from minutely sericeous-pubescent glabrate, about one-third included or covered at the base only. (See pls. 85 to 88 .)

Range: Mountains of Guatemala (where it is very common), Chiapas, and El Salvador (600 to 2,800 m.); type from Guatemala (Warscewicz 12 and 14) without further data.

Quercus tristis is adequately distinguished from all other annualfruited species of Erythrobalanus in Central America by its small impressed-veiny leaves which are bullate-granular beneath at maturity.

As in the case of the other polymorphic species with lengthy syn- 
onymy, $Q$. tristis has an abundance of leaf forms which seem dependent variously upon growth conditions, degree of maturity, etc., and exhibit no fundamental differences. Even the question of whether Q. tristis may legitimately be held distinct from the central Mexican Q. castanea Nee is a problematic one. It seems that the Guatemalan population, as represented by an abundance of herbarium specimens, has a different aspect and a different range of variation from a similar representation of $Q$. castanea. It is doubtful that the persistence of the tomentum on the under leaf surfaces of $Q$. castanea would serve alone to distinguish it from $Q$. tristis in which a similar tendency is seen. The problem needs a field study of the two populations and a careful search of the intervening area.

Specimens examined:

MEXICO-ChiApas: Copainala, February 1939, Martinez 372 (USNA); Cintalapa, February 1939, Martinez 376 (USNA).

GUATEM ALA.- Without legible locality or date, Skinner without number (NY). Dept. Huenuetenango: near Huehuetenango, April 1921, "Leg. Estadistica" [Tonduz] 461 (US); without exact locality, September 3, 1934, Skutch 1105 (AA, F, Ill) ; Rio Pucal, February 20, 1939, Standley 65824 (F, USNA) ; Standley 65827 (F) ; Rio Pucal, $14 \mathrm{~km}$. south of Huehuetenango, January 4, 1941, Standley 82253, 82256 , and 82315 (USNA); near ruins of Zaculeu, January 8, 1941, Standley 82765 (USNA); near Puente de Xinaxo, $13 \mathrm{~km}$. west of Huehuetenango, December 30, 1941, Standley 81545 (USNA). Dept. SAN MARcos: barrancas on slopes of Volcan Tejumulco, 6 miles southwest of Tejumulco, February 26, 1940, Steyermark 36623 (F, USNA). Dept. Quezaltenango: Volcan Santa Maria, May 8, 1937, Muenscher 12493 (F); Volcan Santa Maria, above Santa Maria de Jesus and Las Mojadas, January 12, 1940, Steyermark 33938 (F, USNA); Rio Samala below Zunil, January 24, 1940, Steyermark 34968 and 34982 (F); Steyermark 34970 (F, USNA). Dept. Chimaltenango: Alameda, September 30, 1937, Johnston 997 (F) ; Barranco de la Sierra, southeast of Patzum, December 31, 1938, Standley 61627 (F, USNA); between Chimaltenango and San Martin de Jilotepeque, November 25, 1938, Standley 57918 (F, USNA); December 22, 1940, Standley 80895 (USNA); Rio Guacalate, southeast of Chimaltenango, December 14-23, 1940, Standley 81072 (USNA); near Rio Pixcayo, between Chimaltenango and San Martin de Jilotepeque, February 3, 1939, Standley 64372 and 64487 (F, USNA). Dept. Guatemala: near Guatemala, July 1860, Hayes without number (AA, G [5]); Finca El Naranjo, February 1923, Salas 203 (US); near Finca La Aurora, 1938-1939, Aguilar 211, 242, and 243 (F); Volcan Pacaya, about Las Calderas, November 30, 1938, Standley 58311 (F, USNA). Dept. SACatepequez: near Antigua, November 1938-February 1939, Standley 61696 and 61753 (F, USNA); Cuesta de las Cañas, above Antigua, December 6, 1938, Standley 58886 (F [2], USNA); Cerro de la Cruz, above Antigua, January 22, 1939, Standley 63304 (F, USNA); Finca El Hato, northeast of Antigua, December 28, 1938, Standley 61248 (F); Standley 61224 and 61252 (F, USNA); hills of Finca Carmona, southeast of Antigua, January 27, 1939, Standley 63675 and 63741 (F, USNA); between Mixco and Antigua, April 16,1915, Trelease 31 (Ill [type of f. mixcoensis]); Rio Guacalate, between Antigua and Chimaltenango, December 23, 1940, Standley 80982 (USNA); between Mixco and Santa Lucia, April 16, 1915, Trelease 56 (Ill[2]); Trelease 57 (Ill [2]); April 15, 1915, Trelease 58, (Ill [4]); near San Lucas, October 21, 1916, Popenoe 685 (US, USNA); Volcan Acatenango, February 20, 1905, Kellerman 4833 (US); Volcan de Agua, north of Santa Maria de Jesus, December 10. 1938, Standley 59440 (F[2], USNA); barranco above Dueñas, January 21, 1939, Standley 63134 and 63183 (F, USNA) ; near Pastores, December 14, 1938, Standley 59900 and 59953 (F, USNA); above Pastores, December 23, 1938, Standley 60756 (F, USNA[2]). Dept. Amatitlan: Lake Amatitlan, February 2, 1906, Kellerman 6563 (F); Las Cachiplanas, Volcan Pacaya, April 4, 1921, Tonduz 458 (US). DePt. JALAPA: Volcan Jumay, north of Jalapa, December 1, 1939, Steyermark 32422 (F[2]); Steyermark 32425 and $32430(\mathrm{~F})$; north of Jalapa toward La Laguna, November 11, 1940, Standley 76907 (USNA); Cerro Alcoba, east of Jalapa, December 2, 1939, Steyermark 32543 and 32601 (F, USNA); Montaña Durazno, 2 miles east of San Pedro Pinula, December 10, 1939, Steyermark 32995 (F, USNA). Dept. Chiquimula: Rio Taco, between La Laguna and Chiquimula, October 27, 1939, Steyermark 30730 (F); Volcan Nube (Montaña 
Volcancitos), between Cerro Socorro and Cerro Brujo, southeast of Concepcion de las Minas, October 31, 1931, Steyermark 30895 and $30902(\mathrm{~F})$. DEPT. JUTIAPA: Los Llanitos. near San Jose Acatempa, December 21, 1938, Standley 60583 and 60611 (F, USNA); Volcan Suchitan, northwest of Asuncion Mita, November 18, 1939, Steyermark 31890 (F, USNA).

Series Crassifoliae Trel., Mem. Nat. Acad. Sci. 20: 128. 1924.

Medium-sized trees; twigs rather coarse and persistently tomentose; buds ovoid-fusiform; leaves evergreen or deciduous, thick, rather large, characteristically obovate, coarsely toothed or rarely entire, aristate-tipped, glabrate and impressed-veiny above, persistently mostly rusty-tomentose beneath; petioles moderately long or short; fruit annual or biennial, medium-sized, on short peduncles, the cup scales thin, appressed, tomentose.

Range: Central and western Mexico to Guatemala.

Includes: Q. brachystachys Benth. in Guatemala and several Mexican species of which Q. crassifolia Humb. and Bonpl. is the type.

\section{Quercus brachystachys Benth., Pl. Hartw. 91. 1842.}

Small or medium-sized tree. Twigs coarse (3 to $5 \mathrm{~mm}$. thick), rather markedly fluted, persistently gray- or rusty-velvety-tomentose, tomentulose and with a gray bloom the second season, reddish brown where denuded, lenticels not evident. Buds $3 \mathrm{~mm}$. long or more, ovoid, rather hairy; stipules caducous, about $10 \mathrm{~mm}$. long. ligulate, dorsally pubescent or glabrous. Leaves evergreen or falling as the verdure appears, very thick and coriaceous, 4 to usually about 10 or even $15 \mathrm{~cm}$. long, 2 to usually 6 or even $10 \mathrm{~cm}$. broad, obovate or sometimes oblong or ovate, acuminate or sometimes broadly obtuse but aristate-tipped, cordate or rarely merely rounded or truncate at base, repandly and rather coarsely toothed, the teeth aristate-tipped or simply reduced to aristae, margins rather coarsely revolute, upper surface somewhat shining, glabrous except the stellate-tomentose midrib and principal veins, lower surface persistently fulvous-tomentose, the lamina where denuded strongly bullate-granular and somewhat waxyglaucous; veins about 8 to usually 10 on each side, branching and obscurely anastomosing, ultimately passing into the teeth, strongly impressed (as is the reticulum) above, quite prominent beneath; petioles 12 to 22 or rarely only $4 \mathrm{~mm}$. long, persistently tomentose. Staminate catkins about $7 \mathrm{~cm}$. long, tomentose, rather loosely flowered, the glabrous mucronate anthers well exserted. Pistillate catkins 1 to 2 or rarely $5 \mathrm{~cm}$. long, 2- to 4 - or even 10 -flowered, the peduncle tomentose. Fruit biennial, medium-sized, solitary, paired, or in threes on a pubescent peduncle about 10 to $20 \mathrm{~mm}$. long and 3 or $4 \mathrm{~mm}$. thick; cups about $15 \mathrm{~mm}$. broad, $10 \mathrm{~mm}$. high, the bases often somewhat constricted, margins not inrolled, the scales ovate, obtuse, thin and closely appressed, canescent or the margins glabrate and light brown; acorns 15 to $18 \mathrm{~mm}$. long, 10 to $12 \mathrm{~mm}$. broad, ovoid or narrow-ovoid, glabrous and light brown, about one-half included. (See pls. 89 and 90.)

Range: Mountains of Guatemala and Chiapas; type from San Lucas, Guatemala (Hartweg 618).

Quercus brachystachys is one of the most readily distinguished species in Central America. Its large thick obovate leaves with coarse or aristate teeth, veins deeply impressed above, tomentose beneath, persistently tomentose coarse twigs, and biennial fruit combine to 
exclude all other Central American species. It is distinguished from the Mexican species of the series Crassifoliae by its biennial fruit. The forms described under this species by Trelease are best referred to $Q$. crispipilis var. pannosifolia.

Specimens examined:

MEXICO.-Chiapas: Las Casas, February 1939, Martinez 366 (USNA); July 1940, Martinez 384 (USNA).

GUATEMAlA.-Dept. Huehuetenango: San Juan Ixcoy, August 22, 1934, Skutch 1072 (F, Ill); near Chalchitan, January 14, 1939, Standley 62578 (F); mountains southwest of Malacatancito, January 14, 1939, Standley 62607 (F); Standley 62615 (F, USNA); Sierra de los Cuchumatanes above Chiantla, February 19, 1939, Standley 65607 (F). Dept. Quezaltenango: Volcan Santa Maria above Palojunoj, March 6, 1939, Standley 67537 (F). Dept. Totonicapan: between San Francisco El Alto and Momostenango, January 19, 1941, Standley 84084 (USNA). Dept. Quiche: Chichicastenango, May 9, 1937, Muenscher 12498 (F); south of Chichicastenango, January 11, 1939, Standley 62362 (F); Standley 62395 (F, USNA); between Quiche and Totonicapam, May 16, 1906, Cook 25 and 30 (US); between Quiche and San Pedro Jocopilas, January 12, 1939 , Standley 62458 (F). Dept. Chimaltenango: Garrucha, March 1892, Heyde and Lux 3152 (G); Volcan Acatenango, February 6, 1907, Kellerman 6442 (F); Cumbre del Aire, January 1, 1937, Johnston 514 (F); Finca La Alameda near Chimaltenango, December 11-22, 1940, Standley 79797 (USNA); Barranco de la Sierra southeast of Patzum, December 31, 1938, Standley 61628 (F, USNA); near San Martin Jilotepeque, February 3, 1939, Standley 64401 (F, USNA). Dept. Guatemala: near Finca La Aurora, 1940, Aguilar 444 and 448 (F). Dept. Sacatepequez: between Mixco and Antigua, April 15, 1915, Trelease 43, 44, 45, 46, and 47 (Ill); near Antigua, November 1938-February 1939, Standley 63863 (F, USNA); highest point between Antigua and Vamos, July 30, 1860, Hayes without number (G); Finca El Hato, northeast of Antigua, December 28, 1938, Standley 61217 (F, USNA); Cuesta de las Cañas above Antigua, December 6, 1938, Standley 58848 (F [2], USNA); San Lucas, April 1890, Smith 2189 (G, US); October 21, 1916, Popenoe 681 (US, USNA); San Rafael, February 1892, Smith 2628 (G, US [2]); Volcan de Agua, above Santa Maria de Jesus, February 11, 1939, Standley 65217 (F). Dept. Jalapa: between Jalapa and Mataquescuintla, 6 miles south of Miramundo toward Montaña Miramundo, December 5, 1939, Steyermark 32740 (F, USNA).

Series Acatenangenses Trel., Mem. Nat. Acad. Sci. 20: 162. 1924.

Medium-sized or large trees; twigs slender, glabrate; buds small, ovoid, acute, glabrate or pubescent, the stipules caducous; leaves evergreen, rather small, entire or rarely toothed, nearly glabrous; veins branching and anastomosing, raised on both surfaces; petioles short or moderately long, often winged; fruit biennial, medium-sized or small, the cups cup-shaped or deeper, the scales narrowed, canescent to glabrate.

Range: Mountains of Guatemala and Chiapas, Mexico.

Includes: Q. acatenangensis Trel. (type) and (?) Q. flagellifera Trel.

35. Quercus acatenangensis Trel., Mem. Nat. Acad. Sci. 20: 163. pl.320. 1924.

Quercus longifolia Liebm., Overs. Danske Vidensk. Selsk. Forhandl. 1854: 185. 1854. Not Q. longifolia Raf., Alsog. Amer. 21. 1838.

Q. acutifolia $\epsilon$ longifolia A. DC. in DC. Prodr. $16^{2}$ : 67. 1864.

Q. xalapensis var. longifolia Wenzig, Jahrb. K. Bot. Gart. Berlin. 3: $210 . \quad 1884$.

Q. donnell-smithii Trel., Mem. Nat. Acad. Sci. 20: 162. pl. 318. 1924 (pro parte) - but not the type number, which is Q. sapotaefolia).

Q. ambivenulosa Trel., Journ. Wash. Acad. Sci. 23: 62. 1933. 
Large tree. Twigs 1 to $2 \mathrm{~mm}$. thick, fluted, glabrous or from sparsely stellate-pubescent glabrate and reddish brown with rather inconspicuous lenticels. Buds about 3 or rarely $4 \mathrm{~mm}$. long, scarcely $2 \mathrm{~mm}$. broad, ovoid, acute, sparsely pubescent or glabrate, light brown; the ligulate stipules early caducous, 5 to $7 \mathrm{~mm}$. long, sparsely pubescent dorsally. Leaves evergreen, rather thick and hard or rarely thin, 3 or usually 5 to 10 or even $15 \mathrm{~cm}$. long, 1 or usually 2 to 3 or even $4.5 \mathrm{~cm}$. broad, typically lanceolate to elliptic or narrowly ovate, acute or acuminate, nor markedly aristate-tipped, cuneate to rarely attenuately narrowed at base or in short-petiolate juvenile forms or stump-sprouts rounded or cordulate, entire or obscurely few-toothed toward the apex, juvenile forms coarsely serrate, margins minutely cartilaginous-revolute and somewhat crisped, upper surface somewhat shining, glabrous or slightly pubescent along the midrib, lower surface less shiny or opaque, glabrous or with rather prominent domatia in the axils of the principal veins, the lamina quite smooth (not bullate); veins about 10 to 14 on each side, branching and rather obviously anastomosing near the margin, slightly raised above and more prominent beneath, the reticulum slightly raised on both surfaces; petioles 5 to 10 or $20 \mathrm{~mm}$. long, in juvenile forms often scarcely $2 \mathrm{~mm}$. long, usually rather prominently winged. Staminate catkins about $3 \mathrm{~cm}$. long, fulvous- or gray-villous, loosely flowered, the oblong anthers well exserted. Pistillate catkins 5 to 10 or even $20 \mathrm{~mm}$. long, the glabrous peduncle usually 2-flowered. Fruit biennial, solitary or paired on a peduncle 5 to $20 \mathrm{~mm}$. long, 2 to usually $4 \mathrm{~mm}$. thick, with large conspicuous lenticels; cups 10 to $20 \mathrm{~mm}$. broad, 7 to $12 \mathrm{~mm}$. high, cup-shaped to turbinate and constricted basally, the scales triangular to lanceolate or ovate, the apices usually narrowed but rounded, sericeous-canescent or locally glabrate; acorns 10 to $17 \mathrm{~mm}$. long, 8 to $14 \mathrm{~mm}$. broad elliptic to ovoid, sparsely puberulent or glabrate, light brown, one-half or only one-third included. (See pls. 91 to 93.)

Range: Mountains of Guatemala where it is very abundant, the Mexican State Chiapas, and perhaps also to be expected in Honduras; type from Guatemala (von Warscewicz 47 and 48) without further data.

Quercus acatenangensis is a highly variable species and therefore very difficult to characterize. The degree of variability, however, is not greater than that of other well-known species in which the segregation of new species has proved unsuccessful (e. g., Q. macrocarpa Michx. and Q. nigra L.). Q. donnell-smithii and Q. ambivenulosa differ in no fundamental characters. The broad-leaved form on which the latter is based merges directly in to the elongate narrow-leaved form of typical Q. acatenangensis. The specimen cited as the type of $Q$. donnellsmithii (Smith 1967) is actually Q. sapotaefolia, but Trelease's concept of Q. donnell-smithii is obviously based upon a specimen of Q. acatenangensis. His illustration ( $p l .318)$, although labeled in the explanation as Smith 1967 and described as two variants of the type, is clearly made from Smith 2629. Two sheets of this latter number are to be seen in the United States National Museum and the New York Botanical Garden, both quite clearly exhibiting the two variants illustrated although neither sheet is the actual one photographed. The description of the species is obviously based upon the illustrated but mislabeled Smith 2629 rather than the cited number 1967. 
This species is much like Q. benthami, Q. seemanni, and Q. eugeniaefolia of farther southeast, but its biennial fruiting habit seems to distinguish it amply from them. The questionably related $Q$. flagellifera is distinguished below.

Specimens examined:

MEXICO.-Chiapas: Mount Paxtal [spelled "Pasitar" on labels], December 30, 1936, Matuda 1074 (Mi) ; Mount Ovando, April 1936, Matuda 296 (Mi) ; Las Casas, February 1939, Martinez 363 (USNA); Motozintla, May 1939, Martinez 369 (USNA); August 1939, Martinez 380 (USNA) ; Cintalapa, February 1939, Martinez 371 and 377 (USNA).

GUATEMAlA.-Dept. Huenuetenango: San Juan Atitan, September 8 , 1934, Skutch 1155 (F, Ill). Dept. SAN Marcos: above Rio Tacana, near San Antonio, February 22, 1939, Standley 66083 and 66100 (F); El Boqueron, summit of road between San Antonio Sacatepequez and Palestina, January 30, 1941, Standley 85284 (USNA); Puente de Nahuatl-aa, near San Marcos, February 22, 1939, Standley 66204 and 66208 (F, USNA); Standley 66217 (F); between San Sebastian and top of Volcan Tajumulco, February 16, 1940, Steyermark 35780 and 35781 (F); nearTajumulco, northwest slopes of Volcan Tajumulco, February 28, 1940 . Steyermark 36914 (F); Steyermark 36916 (F, USNA). Dept. Quezaltenango: Quezaltenango, April 7, 1915, Trelease 54 (Ill [5]); 1922, Hurter 2 (Ill [2]); mountains above Olintepeque, February 20, 1939, Standley 65959, 65964, 65966, 65974, and 65975 (F, USNA) ; above (north of) Olintepeque, January 29, 1941, Standley 85213, $8521 \%$, and 85225 (USNA); southeast of Palestina toward San Juan Ostuncalco, January 21, 1941, Standley 84356 and 84358 (USNA); mountains southeast of Palestina, February 22, 1939, Standley 66359 (F, USNA); mountains above Ostuncalco, February 22, 1939, Standley 66380 and 66403 (F, USNA); between Concepcion Chiquirichapa and San Martin Chile Verde, January 16, 1941, Standley 83595 (USNA); Volcan Santa Maria, January 24, 1896, Nelson 3720 (G, US [2]); Volcan Santa Maria, above Palojunoj, March 6, 1939, Standley 67536,67539 , and 67543 (F); Standley 67538 (F, USNA); January 15, 1941, Standley $83405,83561,83565,83567$, and 83583 (USNA); Volcan Santa Maria, above Santa Maria de Jesus and Los Mojados, January 12, 1940, Steyermark 34036 (F, USNA). Dept. Totonicapan: Cumbre del Aire, between Huehuetenango and Sija, January 14, 1939, Standley 62640 and 62649 (F, USNA); January 11, 1941, Standley 83117 (USNA); between San Francisco El Alto and Momostenango, January 19, 1941, Standley 84025 and 84098 (USNA); region of Chuiquisis, above Totonicapan toward Desconsuelo, January 23, 1941, Standley 84396 (USNA). Dept. BaJA Verapaz: north of Santa Rosa, March 30, 1939, Standley 69721 (F, USNA). Dept. Quiche: between Quiche and Totonicapan, May 16, 1906, Cook 28 (US); barranco south of Chichicastenango, January 11, 1939, Standley 62394 (F, USNA). Dept. Chimaltenango: Chichavac, NovemberDecember 1930, Skutch 14 (US [2] [types of Q. ambivenulosa]); Skutch 53 (Ill, US); February 18, 1933, Skutch 252 (ƯS); November 14, 1933, Skutch 691 (US); Cumbre del Aire, January 1, 1937, Johnston 520 (F); Volcan Acatenango, February 6, 1907, Kellerman 6443 (F); Volcan Acatenango, above Las Calderas, January 3, 1939, Standley 61773 (F, USNA). Dept. Guatemala: Finca La Aurora, 1938-1939, Aguilar 291 (F) ; 1940, Aguilar 449 (F). Dept. Sacatepequez: Guatemala to Antigua (toward San Lucas), April 15, 1915, Trelease 52 (Ill [2]) ; near Antigua, February 4,1907, Kellerman 6497 (US); Cuesta de las Cañas, above Antigua, December 6, 1938, Standley 58892 (F, USNA); Finca El Hato, northeast of Antigua, December 28, 1938, Standley 61140 (F, USNA); hills of Finca Carmona, southeast of Antigua, January 27, 1939, Standley 63687 and 63787 (F, USNA); Volcan de Agua, north of Santa Maria de Jesus, December 10, 1938, Standley 59344 (F, USNA); Standley 59469 (F); Volcan Acatenango, March 1892, Smith 2629 (G, NY, US [2] [illustrated as type of $Q$. donnell-smithii but misnumbered]) ; Februarv 20, 1905, Kellerman 4826, 4828, and 5151 (US) ; San Rafael, February 1892, Smith 2627 (G, US [2]); above Las Calderas, December 15, 1938, Standley 59984 (F, USNA). DePT. JALAPA: Volcan Jumay, north of Jalapa, December 1, 1939, Steyermark 32408 (F); hills between Guisiltepeque and Potrero Carrillo, December 11, 1939, Steyermark 33029 (F, USNA).

36. Quercus flagellifera Trel., Mem. Nat. Acad. Sci. 20: 162. pl. 319. 1924.

Large tree. Twigs 1 to scarcely $2 \mathrm{~mm}$. thick, finely fluted, from stellate-villous becoming glabrate and reddish brown, the lenticels 
scarcely evident until the second season. Buds?; stipules persistent only a short time, ligulate, 8 to $10 \mathrm{~mm}$. long, dorsally pubescent. Leaves evergreen, rather thin but becoming coriaceous, about 8 to $16 \mathrm{~cm}$. long, 1.5 to $2.5 \mathrm{~cm}$. broad, linear-lanceolate to linear-oblanceolate, attenuately very long-acuminate (the long tips often broken off but never really lacking), often aristate-tipped besides, the gradually narrowed base finally cuneate or rarely minutely rounded, entire or rarely obscurely few-aristate-toothed toward the apex, margins rather prominently but finely revolute, very finely crisped, upper surface rather shiny, glabrous or inconspicuously pubescent especially about the base of the midrib, lower surface shiny, glabrous or the midrib sometimes sparsely stellate-pubescent; veins 18 to 24 on each side issuing at an angle of 80 or 85 degrees from the midrib, with evanescent or rather prominent intermediates (the attenuate narrow tip usually containing 8 to 10 additional veins with intermediates beyond the point one ordinarily counts the principal veins), not raised above and not impressed or the principal ones rather prominent within slight depressions, rather prominent beneath, the reticulum slightly raised above and less so beneath; petioles about $2 \mathrm{~mm}$. long, tardily glabrate. Catkins and fruit? (See pls. 94 and 95.)

Range: Mountains of east-central Guatemala.

Quercus flagellifera is a somewhat problematic species. Its exceedingly narrow and long-acuminate leaves and its numerous veins readily set it off from any other species, but one specimen (Steyermark 36039) seems to be intermediate between this species and Q. acatenangensis. Its very short petioles, however, suggest $Q$. flagellifera. Were it not that shade forms, juvenile forms, and stump-sprouts of Q. acatenengensis usually exhibit quite a different type of short-petioled leaves, it might seem best to regard $Q$. flagellifera as a shade form of that species. The evidence points rather to its being a very distinct species questionably referred to this series.

Specimens examined:

GUATEMALA.-Dept. San Marcos: Volcan Tacana, between Sibinal and Canjula along Quebrada Canjula, February 18, 1940, Steyermark 36039 (F, USNA). Dept. Alta Verapaz: Secoyocti, near Finca Sepacuite, April 14, 1902, Cook and Griggs 60\% (US [type]). Dept. Chiquimula: Volcan de Quezaltepeque, northeast of Quezaltepeque, November 8, 1939, Steyermark-31476 (F).

Series Acutifoliae Trel., Mem. Nat. Acad. Sci. 20: 187. 1924.

Series Grandes Trel., Mem. Nat. Acad. Sci. 20: 184. 1924. Series Huitamalcanae Trel., Mem. Nat. Acad. Sci. 20: 185. 1924. Series Brenesieae Trel., Mem. Nat. Acad. Sci. 20: 186. 1924. Series Skinneriae Trel., Mem. Nat. Acad. Sci. 20: 187. 1924. Series Albocinctae Trel., Mem. Nat. Acad. Sci. 20: 193. 1924.

Small or large trees; twigs slender, glabrate; buds ovoid to conic or fusiform, stipules caducous; leaves deciduous or evergreen, rather thin or moderately thick and firm, medium-sized or large, ovate to characteristically lanceolate, coarsely toothed or entire, glabrous or pubescent beneath; petioles moderately short or elongate; fruit annual or biennial, small or very large, cups hemispheric to saucer-shaped.

Range: Texas, throughout the mountains of Mexico, and Guatemala, British Honduras, Honduras, El Salvador, and Costa Rica.

Includes: Q. skinneri Benth., Q. monserratensis C. H. Mull., Q. conspersa Benth., Q. brenesii Trel., Q. tenuiaristata Trel., Q. paxtalensis 
C. H. Mull., Q. anglohondurensis C. H. Mull., Q. gracilior C. H. Mull., and several Mexican species of which Q. acutifolia Nee is the type.

The series Acutifoliae is the most nearly natural of all the groups named under that category. It is difficult to characterize as its species are superficially so diverse. In some species the characteristically aristate-tipped teeth do not appear on typical plants but only on root sprouts and similar variants.

37. Quercus skinneri Benth., Gard. Chron. 1841: 16. 1841; Pl. Hartw. 90. 1842.

Quercus grandis Liebm., Overs. Danske Vidensk. Selsk. Forhandl. 1854: 183.1854.

Q. chiapasensis Trel., Proc. Amer. Philos. Soc. 54: 9. pl. 2. 1915.

Q. grandis var. tenuipes Trel., Mem. Nat. Acad. Sci. 20: 185. pl.373. 1924.

Q. chiapasensis f. falcilobata Trel., Mem. Nat. Acad. Sci. 20: 186. pl. 375. 1924.

Q. chiapasensis f. flagellata Trel., Mem. Nat. Acad. Sci. 20: 186. 1924.

Q. chiapasensis f. cuneifolia Trel., Mem. Nat. Acad. Sci. 20: 186. 1924.

Q. chiapasensis f. subcuneata Trel., Mem. Nat. Acad. Sci. 20: 186. 1924.

Q. chiapasensis f. petiolata Trel., Mem. Nat. Acad. Sci. 20: 186. 1924.

Q. chiapasensis f. longipes Trel., Mem. Nat. Acad. Sci. 20: 186. 1924.

Q. salvadorensis Trel. in Standley, Field Mus. Bot. Ser. 8: 5. 1930.

Q. hemipteroides C. H. Mull., Amer. Midl. Nat. 18: 853. 1937.

Q. trichodonta Trel. in Yuncker, Field Mus. Bot. Ser. 17: 358. 1938.

Small to very large tree. Twigs 2 to $4 \mathrm{~mm}$. thick or occasionally more slender, coarsely fluted, glabrous or from loosely fulvous-tomentose becoming glabrate, dark reddish brown with few rather conspicuous pale lenticels. Buds 4 to $7 \mathrm{~mm}$. long, ovoid, obtuse, obscurely angular and the scales often in vertical series, sparsely pubescent or glabrate and light brown; the ligulate pubescent stipules 7 to $10 \mathrm{~mm}$. long, very early caducous. Leaves subevergreen or apparently deciduous, thin and membranous, 8 to usually 12 or sometimes even 30 $\mathrm{cm}$. long, 3 to usually 6 or even $12 \mathrm{~cm}$. broad, broadly lanceolate or obovate to lanceolate or oblanceolate, the apex tapered or acuminate, base cuneate to rounded or cordulate, coarsely or finely and low-or attenuate-toothed and the teeth long-aristate-tipped, or subentire and the teeth replaced by aristae, the margins very finely cartilaginous but scarcely revolute, crisped or flat, both surfaces glabrous and rather lustrous or with inconspicuous tufts of hairs in the axils of the veins and along the midrib beneath; veins about 10 to 15 on each side, branching and obscurely anastomosing but obviously passing into the teeth where these are present, slightly raised above, more prominent beneath, the reticulum raised on both surfaces; petioles 2 to 4 or even $5 \mathrm{~cm}$. long, sometimes as short as $3 \mathrm{~mm}$. and then the blade decurrent, rather obviously winged distally in the longer ones or the full length 
in the shorter ones, glabrous or from loosely fulvous-tomentose promptly or tardily glabrate. Staminate catkins? Pistillate eatkins about $5 \mathrm{~mm}$. long, 1- or 2-flowered apically. Fruit biennial, large or very large, solitary on a peduncle about $5 \mathrm{~mm}$. long, very polymorphic at different stages of maturity; cups 22 to $45 \mathrm{~mm}$. broad and 8 to 20 $\mathrm{mm}$. high at maturity, saucer-shaped to hemispheric, flattening with maturity or not, scales ovate or narrowed apically, corky-thickened basally and rather rugose, the membranous apex closely appressed, finely fulvous-tomentulose all over when young, variously glabrescent and whitening with maturity or the apex persistently tomentulose; acorns 18 to $40 \mathrm{~mm}$. long and broad, round to depressed or shortcylindric or round-ovoid, the ends usually truncate or rounded, from loosely tomentose soon glabrate, one-fourth included or covered at the base only, the shell very thick and hard; immature fruits round or flattened, the nut fully included or projecting somewhat. (See pls. 96 to 103.)

Range: Chiapas, Mexico, to Guatemala, El Salvador, and Honduras.

Quercus skinneri is one of the more polymorphic species of Central America. The two most misleading characters are the length of petiole and the size and shape of the fruit. The multitude of intergrades (the extremes being relatively few in number) and the total lack of any correlation between characters makes these differences insignificant in this species. Q. grandis is merely a short-petioled form with immature fruit. The same plant with mature fruit becomes Q. chiapasensis. With less prominent teeth and a different range, the fruit unknown, it is Q. trichodonta. Q. salvadorensis differs only in having smaller fruit, and Q. hemipteroides differs not at all.

The very thick acorn shell of this species and its corky-thickened cup scales readily set it off from all others, and its thin, membranous leaves never fulvous-puberulent beneath distinguish it from Q.conspersa with which it is most frequently confused.

Specimens examined:

MEXICO.-Chiapas: Tapachula, Finca San Juan las Chicharras, 1918, Reeves 1 (Ill [type of Q. chiapasensis f. longipes]); Reeves 2 (Ill); Reeves 3 (Ill [type of $Q$. chiapasensis f. cuneifolia]); Reeves 5 (IIl [type of Q. chiapasensis f. falcilobata]); Reeves 6 (Ill [type of Q. chiapasensis f. flagellata]); Reeves 8 (Ill [type of Q. chiapasensis f. petiolata]); Reeves 9 (Ill [type of Q. chiapasensis f. subcuneata]); Reeves 10 (Ill) ; Finca Irlanda, September 1913, Purpus 6999 (F, Ill [2] [types of Q. chiapasensis], US); June 1914, Purpus 6999' (F, US); Cerro Brujo, Ocoxantla, 60 km. south of Tuxtla, August 1940, Martinez 383 (USNA); Copainala, August 1940, Martinez 391 (USNA).

GUATEMALA.- - Without further data, Hartweg without number (US). DEPT. San Marcos: Canguts, July 31, 1922, Salas 13 (US); Volcan Tajumulco, above Finca El Porvenir, March 7, 1940, Steyermark 37193 (F). DePt. Quezaltenango: Volcan Acatenango, between Quezaltenango and the Volcan, 1840, Hartweg 615 (NY [2] [isotypes]); Volcan Santa Maria, between Santa Maria de Jesus and Calahuache, Finca Pirineos, Quebrada San Geronimo, January 1-2, 1940, Steyermark 33313 (F, USNA); Volcan Santa Maria, above Santa Maria de Jesus and Los Mojados, January 12, 1940, Steyermark 33935 (F); Steyermark 33965 (F, USNA); Volcan Zunil, above Santa Maria de Jesus, January 21, 1940 , Steyermark 35097 (F) ; Finca Pirineos, below Santa Maria de Jesus, March 11, 1939, Standley 68418 (F); near Colomba, March 8, 1939, Standley 67998 (F, USNA). Dept. Solala: Volean Atitlan, January 23, 1907, Kellerman 6061 (F, US). Dept. Quiche: Finca San Francisco, December 8, 1934, Skutch 1875 (AA, F, Ill [type of Q. hemipteroides], NY). Dept. Chimaltenango: Panajabal, January 5, 1939 , Stanalley 62127 (F, USNA). Dept. Alta Verapaz: Samac, April 1889, Smith 1709 (NY, US [2]); Secoyocti, near Finca Sepacuite, April 14, 1902, Cook and 
Griggs 615 (US). Dept. BaJa Verapaz; Panzal, October 1912, Türckheim 3899 (US [2]). Dept. Guatemala: Finca La Aurora, 1938-1939, Aguilar 215 (F); 1940, Aguilar 497 (F). Dept. SAcatepequez: Acatepeque, without date, Rodriguez 3636 (G, US [2]); Volcan Fuego, March 1892, Smith 2630 (G, MBG, US [2]); Volcan Acatenango, August 1892, Shannon 3648 (US); near Las Lajas, November 28, 1938, Standley 58065 (F, USNA).

EL SALVADOR.-DEPT. AHUACHAPAN: vicinity of Ahuachapan, January 9-27, 1922, Standley 20267 (NY, US); Cerro de Apaneca, near Finca Colima, January 17-19, 1922, Standley 20154 (US); 1928, Calderon 2429 (F). DEPT. Cuscatlan: summit of Cerro del Guayabal, January 3-4, 1924, Calderon 1981 (US [type of Q. salvadorensis], NY). Dept. SAN Vicente: Volcan San Vicente, March 7-8, 1922, Standley 21599 (MBG, NY, US [2]).

HONDURAS.-Prov. Comayagua: El Achote, above Siguatepeque, July 26 , 1936, Yuncker, Dawson, and Youse 6116 (DeP, F, Ill [photo. in DeP and F] [type of Q. trichodonta], MBG, Mi).

\section{Quercus monserratensis sp. nov. ${ }^{15}$}

Large tree. Twigs 2 to $3 \mathrm{~mm}$. thick, fluted, glabrous or sparsely stellate-pubescent, dark brown with few small but rather conspicuous pale lenticels. Buds about $3 \mathrm{~mm}$. long and $2.5 \mathrm{~mm}$. thick, ovoid, obtuse, glabrous and light brown; the stipules caducous. Leaves deciduous, thin but rather firm, 9 to $15 \mathrm{~cm}$. long, 3 to $5 \mathrm{~cm}$. broad, lanceolate, apex attenuately acute, base cuneate to usually rounded or merely obtuse, acutely coarse-toothed throughout, the teeth longaristate-tipped, margins minutely revolute, both surfaces glabrous or the lower puberulent along the midrib and tufted in the axils of the veins, lustrous above, rather dull beneath; veins about 10 or 11 on each side, intermediates lacking, branching and anastomosing near the margin but clearly passing into the teeth, somewhat raised above, more prominent beneath, the reticulum slightly raised on both surfaces; petioles 20 to usually 30 or even $45 \mathrm{~mm}$. long, $1 \mathrm{~mm}$. thick, prominently winged distally, glabrous. Staminate catkins? Pistillate catkins 5 to $7 \mathrm{~mm}$. long, 1- or 2-flowered distally. Fruit biennial, solitary on a peduncle 6 to $14 \mathrm{~mm}$. long and about $3 \mathrm{~mm}$. thick; cups 20 to $22 \mathrm{~mm}$. broad, 11 to $13 \mathrm{~mm}$. high, cup-shaped, margins not inrolled, scales lance-ovate, the narrowed apex thin and very closely appressed, base keeled or corky-thickened especially toward the base of the cup, gray-puberulent all over except the narrow glabrate and brown margins; acorns depressed, subhemispheric, about $16 \mathrm{~mm}$. broad and $13 \mathrm{~mm}$. high, from minutely puberulent becoming glabrate and light brown, the shell rather thick (about $1.5 \mathrm{~mm}$.) but not exceedingly hard, about one-half or more included. (See pl. 104.)

Range: Chiapas, Mexico.

Quercus monserratensis has been confused with Q. grandis, a Guatemalan form of $Q$. skinneri, as a result of the chance resemblance of mature fruit of $Q$. monserratensis to the immature fruit of $Q$. skinneri, which was the basis of the name grandis. When the fruit size of $Q$. skinneri approaches that of $Q$. monserratensis, as it does in the synonymous Q. salvadorensis, the cups are saucer-shaped and never proportionally so deep as in Q. monserratensis. This new species further differs from Q. skinneri in its smaller buds and less thickened acorn shell; its basally thickened cup scales indicate a close relationship, however.

\footnotetext{
15 Quercus monserratensis sp. nov.-Arbor grandis, ramuli 2-3 mm. crassi glabri vel sparse stellati; gemmae $3 \mathrm{~mm}$. Iongae $2.5 \mathrm{~mm}$. crassae ovoideae obtusae glabrae, folia decidua $9-12 \mathrm{~cm}$. longa $3-5 \mathrm{~cm}$. lata lanceolata attenuato-acuta basi cuneata vel rotundata ubique crasse aristato-dentata glabra vel costa subtus et domatiis exceptis, venis utrinque 10-11, petioli $20-45 \mathrm{~mm}$. longi surcum alati, fructus biennis solitarius brevipedunculatus, cupula 20-22 mm. lata 11-13 mm. alta margine non involuta, squamae stricte appressae basi incrassatae, glans $16 \mathrm{~mm}$. lata $13 \mathrm{~mm}$. alta subhemispherica circa $1 / 2$ inclusa.
} 
Q. monserratensis is distinguished from Q. conspersa by its thinner leaves and cup margins not inrolled. Vegetatively it resembles Q. paxtalensis very closely, but its biennial fruit adequately distinguishes it from that species.

Specimens examined:

MEXICO.-Chiapas: near Hac. Monserrate, April 1927, Purpus 10091 (AA [type]); Zamapam, November 1926, Purpus 10824 (US).

39. Quercus conspersa Benth., Pl. Hartw. 92. 1842.

Quercus acutifolia $\delta$ conspersa A. DC. in DC. Prodr. $16^{2}: 66$. 1864.

Q. acutifolia $\zeta$ microcarpa A. DC. in DC. Prodr. 16²: 67. 1864. Q. correpta Trel., Mem. Nat. Acad. Sci. 20: 153. pl. 300. 1924 (pro parte - not the detached fruit which is Q. sapotaefolia).

Q. grahami var. coyulana Trel., Mem. Nat. Acad. Sci. 20: 190. pl. 384. 1924.

Q. grahami var. nelsoni Trel., Mem. Nat. Acad. Sci. 20: 190. pl. 384. 1924.

Q. conspersa f. ovatifolia Trel., Mem. Nat. Acad. Sci. 20: 192. pl. 389. 1924.

Q. conspersa f. caudata Trel., Mem. Nat. Acad. Sci. 20: 192. 1924.

Large or small tree. Twigs 1.5 to 2.5 or rarely $4 \mathrm{~mm}$. thick, fluted, from minutely stellate-pubescent becoming glabrate and reddish brown with few inconspicuous lenticels, becoming gray the second season. Buds 3 or $4 \mathrm{~mm}$. long, narrowly ovoid, acute, somewhat angular, glabrate or the apex fulvous-tomentose; the stipules promptly caducous. Leaves deciduous, rather thick and very hard, 10 to 15 or sometimes only 6 or as much as $20 \mathrm{~cm}$. long, 3 to 5 or sometimes only 2 or as much as 8 or $10 \mathrm{~cm}$. broad, characteristically lanceolate and long-acute, from oblong to ovate or obovate, apex attenuately acute to acuminate or merely acute, base cuneate to unequally rounded or rarely cordate, entire to coarsely toothed (these two forms often constant in any given specimen), the teeth aristate-tipped or reduced to aristae, antrorse or sometimes widely spreading, margins rather coarsely cartilaginous but scarcely revolute, coarsely crisped or flat, upper surface glabrate and somewhat shining, lower surface glabrate or characteristically fulvous-puberulent (a resinous decomposition of hairs or scales) and stellate-tufted in the axils of the reins; reins 9 to 12 or 15 on each side, more or less obviously branching and anastomosing but finally passing into the teeth where these are present, somewhat raised (as is also the reticulum) above, quite prominent beneath; petioles 8 to 30 or rarely (on stump-sprouts) only $3 \mathrm{~mm}$. long, 1 to 2 $\mathrm{mm}$. thick, rather plainly or obscurely winged distally, puberulent or glabrate with the lower leaf surface. Staminate catkins 6 to $8 \mathrm{~cm}$. long, the rachis densely tomentose or glabrate, rather loosely flowered, the ellipsoid apiculate anthers moderately exserted. Pistillate catkins 5 to $20 \mathrm{~mm}$. long, 2- to 6 -flowered. Fruit biennial, solitary or paired on a peduncle 3 to $10 \mathrm{~mm}$. long, cups 15 to 18 or rarely 22 $\mathrm{mm}$. broad, 7 to 10 or rarely $13 \mathrm{~mm}$. high, cup-shaped to gobletshaped, the base round or somewhat constricted, margins coarsely inrolled and sometimes inflated, rarely simple, scales ovate to triangular, the apex rounded and often much narrowed, rather closely appressed, 
fulvous-pubescent or in age gray-pubescent or glabrate; acorns about 16 or rarely $20 \mathrm{~mm}$. long, 13 or rarely $20 \mathrm{~mm}$. broad, ovoid to subrotund, rounded apically, from minutely puberulent becoming glabrate and light brown, about one-third included. (See pls. 105 to 109.)

Range: Chiapas and the Cordillera region of Mexico to Guatemala and Honduras (900 to $2,800 \mathrm{~m}$.).

Quercus conspersa is the most abundant species of the series Acutifoliae in Central America. Its long-acute leaf apices, thick blades, and small fruit amply distinguish it from Q. skinneri, the only other biennial-fruited species of the series in our range.

The varieties coyulana and nelsoni referred by Trelease to Q. grahami Benth. obviously belong to $Q$. conspersa, although the species $Q$. grahami is apparently distinct. The form called $Q$. correpta is a mixture of a sterile, entire-leaved specimen of $Q$. conspersa and detached fruits of $Q$. sapotaefolia. The element here referred to $Q$. conspersa is illustrated and described by Trelease in terms that unmistakably identify it with this species. For further discussion of this situation see Q. polymorpha.

Specimens examined:

MEXICO.-OAXACA: San Miguel Albarradas, July 2, 1894, Nelson 539 (US [3] [types of Q. grahami var. nelsoni]). ChIAPAs: between Bahucuc and Yaxha, March 23, 1896, Seler 2583 (AA); Los Pinos, June 2, 1904, Goldman 1054 (US) ; Teopisco, December 30, 1906, Collins and Doyle 118 (US); Mount Paxtal [spelled "Pasitar" on labels], December 29, 1936, Matuda 471 (Mi, US, USNA); Mount Ovando, November 14-18, 1939, Matuda 3927 (USNA); Mount Male, near Porvenir, July 6, 1941, Matuda 4653 (USNA); Nuevo Amatenango, July 17, 1941, Matuda 4748 (USNA); Coapilla, March 1939, Martinez 389 (USNA).

GUATEMALA.-Without further data, Hartweg 617 (NY [isotype]); Skinner without number (NY); Warscewicz 26 (G); 1892, Heyde 1 (US). DEPT. HuenueTENANGO: without exact locality, September 4, 1934, Skutch 1133 (F. Ill); hills east of Aguacatan, January 14, 1939, Standley 62553 (F, USNA); $10 \mathrm{~km}$. east of Huehuetenango toward Aguacatan, January 2, 1941, Standley 82076, 82104, and 82168 (USNA); northwest of Malacatancito, $8 \mathrm{~km}$. from Huehuetenango, January 4, 1941, Standley 82183 and 82213 (USNA); mountains southwest of Malacatancito, January 14, 1939, Standley 62613 and 62617 (F, USNA); Rio Pucal, February 20, 1939, Standley 65830 (F, USNA); Rio Pucal, 14 km. south of Huehuetenango, January 4, 1941, Standley 82331 and 82346 (USNA); east of San Sebastian, December 29, 1940, Standley 81437 (USNA); near crossing of Rio San Juan Ixtan, east of San Rafael Petzal, January 9, 1941, Standley 83011 and 83044 (USNA). Dept. Quezaltenango: lower north slopes of Volcan de Santa Maria above Palojunoj, January 15, 1941, Standley 83474 (USNA); toward San Juan Ostuncalco from Palestina, January 21, 1941, Standley 84360 (USNA). Dept. San Marcos: Volcan Tajumulco, southwest of Tajumulco, February 25, 1940, Steyermark 36566 (F); February 26, 1940, Steyermark 36615 (F, USNA). DePt. Quiche: Rio Negro, March 1892, Heyde and Lux 3154 (G, US [2]); Zacualpa, without date, Wauchope 7 (Mi); great barranco of Rio Blanco, above Sacapulas, January 12, 1939, Standley 62495 (F, USNA). Dept. Chimaltenango: Chichavac, March 4, 1933, Skutch 315 (US); Lake Nyarza, April 8, 1936, Lewis 305 (F); between Chimaltenango and San Martin Jilotepeque, November 25, 1938, Standley 57912 and 57923 (F, USNA); December 22, 1940, Standley 80865 and 80872 (USNA). Dept. BAJA Verapaz: above Purulha, June 1904, Cook 288 (US); Santa Rosa, June 5, 1904, Cook 247 (US); October 1912, Türckheim 3898 (US); hills north of Santa Rosa, March 30, 1939, Standley 69701, 69716, and 69824 (F); between Santa Rosa and Purulha, June 1904, Cook 278 (US); Cuesta de Chuacus, near Salama, April 19, 1905, Pittier 131 (US [2]); above Salama, February 1940, Lewis 1117 and 1118 (F); between Salama and Rabinal, May 31, 1904, Cook and Doyle 282 (US); Rabinal, May 9, 1906, Cook 14 (US). DePT. Guatemala: Finca La Aurora, 1939, Aguilar 160 (F); about Guatemala, July 1860, Hayes without number (G [2]); hills between Guatemala and San Raimundo, January 18, 1939, Standley 62947 and 63012 (F, USNA); Finca Bretaña, between Guatemala and Fiscal, December 12, 1938, Standley 59741 and 59747 (F, USNA); 
between Chiquin and Trapiche Grande, April 19, 1905, Pittier 129 (L'S); Fiscal, May 31, 1909, Deam 6087 (G, Mi, US); June 9, 1909, Deam 6218 (Mi, ÚS); San Antonio Mountain. January 11, 1906. Kellerman 5028 (US [2]). Dept. SACATEPEQโEZ: between Antigua and Guatemala, April 16, 1915. Trelense 53 (III [2]). Dept. Santa Rosa: Santa Rosa, May 1892, Heyde and Lux 3151 (G, US [2]); Aguacaliente. January 25. 1908, Kellerman rigo (F [2]): Municipio de Casillas, 1938-1939, Aguilar $344^{\circ}(\mathrm{F})$. Dept. ZaCAPA: Sierra de las Minas, Finca Alejandria above Rio Hondo, October 11, 1939, Steyermark 29697 (F). Dept. Jalapa: Rio Jalapa, between Jalapa and San Pedro Pinula, December 9, 1939, Steyermark 32.937 (F, USNA); vicinity of Jalapa, November 7-18, 1940, Standley 77394, 76739 , and 76752 (USNA); between Jalapa and Paraiso, November 14, 1940, Standley r\%241 (USNA).

HONDURAS.-Dept. Tegucigalpa: Mont. de la Flor, near Tegucigalpa, December 13, 1937, von Hagen 1219 (F, NY); December 15, 1937, von Hagen 1246 (F, NY).

40. Quercus brenesii Trel., Mem. Nat. Acad. Sci. 20: 186. pl. 3r7. 1924.

Medium-sized or large tree. Twigs 1 to $2 \mathrm{~mm}$. thick, fluted, glabrous or from loosely or closely fulvous-tomentose promptly or tardily glabrate and dark reddish brown with few small light lenticels, graving the second or third season. Buds 2 to $3 \mathrm{~mm}$. long. oroid and obtuse when young, becoming 4 or $5 \mathrm{~mm}$. long and narrowly fusiform, glabrate, glossy brown; the ligulate stipules 4 or $5 \mathrm{~mm}$. long, early caducous. Leares deciduous, thin and membranous, 6 to 12 or eren $15 \mathrm{~cm}$. long, 1.5 to $3 \mathrm{~cm}$. broad, lanceolate to linear-lanceolate, apex long-acute or long-acuminate, base narrowly cuneate or merely acute, in one short-petioled form cordulate, coarsely or finely toothed above the middle or rarely entire, the teeth broadly spreading, acute and aristate-tipped, both surfaces from buff-stellate-tomentulose becoming glabrate and lustrous except the under surface sometimes rather sparsely pubescent along the midrib; reins about 10 or 12 to 15 or rarely more on each side, branching and rather obscurely anastomosing but finally passing into the teeth where these are present, raised on both surfaces (including the rerv fine reticulum) or the principal ones rarely impressed above and raised within the groores; petioles 2 to 6 mm. long, obscurely or prominently winged, glabrate with the twigs. Staminate catkins about $6 \mathrm{~cm}$. long, rery loosely flowered, rachis from stellate-tomentose glabrate, the perianth persistently tomentose, the oblong and obriously apiculate anthers moderately or well exserted. Pistillate catkins about $5 \mathrm{~mm}$. long. distally 1-or 2-flowered. Fruit annual, solitary or paired on a peduncle 5 to $10 \mathrm{~mm}$. long; roung cups with closely appressed broadly rounded orate or oblong gray- or buff-puberulent scales, markedly constricted at base or not. Mature fruit not seen. (See pls. 110 and 111.)

Range: Central Costa Rica (about 600 to $1,200 \mathrm{~m}$.).

Quercus brenesii is distinguished from the other annual-fruited species of the series Acutifoliae. except Q. gracilior. by its very narrow leares toothed only above the middle. From Q. gracitior it is distinguished by its peduncled fruit and its early caducous ligulate stipules.

Specimens examined:

COSTA RICA.-Dept. Alajuela: La Palma de San Ramon, December 7, 1926, Brenes 5178 and 5194 (F); June 27, 1927, Brenes 5566 (F); August 3-10, 1935, Quiros 187 (F); between La Palma and El Socorro de San Ramon, July 24, 1928, Brenes 62?' (F): between San Ramon and La Palma [de San Ramon], January 17, 1928, Brenes $6010(\mathrm{~F})$; between Cerro del Mondongo and Santiago 
de San Ramon, January 9, 1930, Brenes 11602 (F); January 23, 1933, Brenes 16966 (F); Rio Jesus, between San Ramon and San Mateo, June 21, 1901, Brenes 14520 (US [2] [isotypes]).

41. Quercus tenuiaristata Trel. in Yuncker, Field Mus. Bot. Ser. 17: 358. 1938.

Small tree or shrub. Twigs 2 to $3 \mathrm{~mm}$. thick, fluted, from densely loose-fulvous-tomentose rather tardily glabrescent and the tomentum graying, reddish brown with a gray bloom and few inconspicuous lenticels the second or third season. Buds about $3 \mathrm{~mm}$. long, narrowly ovoid, obtuse, glabrescent except the fulvous-ciliate scales, glossy brown; the broadly ligulate stipules about $10 \mathrm{~mm}$. long, sparsely villous, at length caducous. Leaves evergreen, 6 to usually 10 or even $13 \mathrm{~cm}$. long, 2 to usually 3 or even $5 \mathrm{~cm}$. broad, lanceolate or narrowly lanceolate, apex attenuately acute or acuminate, base narrowly and unequally rounded to cordate, coarsely toothed or the margin merely minutely long-aristate, both surfaces from densely fulvous-tomentose soon glabrate and somewhat lustrous; veins about 12 to 16 on each side without intermediates, obscurely if at all branching and anastomosing, passing into the teeth, somewhat impressed above and raised within the grooves, very prominent beneath, the reticulum very slightly raised above and more prominently so beneath; petioles 3 to $7 \mathrm{~mm}$. long, 1 to $2 \mathrm{~mm}$. thick, from fulvoustomentose tardily glabrescent with the twigs. Catkins and fruit? (See pl. 112.)

Range: Central Honduras (about 1,400 m.).

Quercus tenuiaristata is only questionably assigned to the series Acutifoliae although it obviously does not belong to the series Tristes to which Trelease originally assigned it with equal doubt. Its impressed venation clearly distinguishes it from the other species of the series Acutifoliae.

Specimens examined:

HONDURAS.-DePt. Comayagua: West of El Achote, above Siguatepeque, July 28, 1936, Yuncker, Dawson, and Youse 6204 (DeP, F [also photograph of type in Ill], MBG, Mi [isotypes]).

\section{Quercus paxtalensis sp. nov. ${ }^{16}$}

Probably medium-sized or large tree. Twigs 1 to $2 \mathrm{~mm}$. thick, fluted, glabrous, dark reddish brown with few small light lenticels, becoming gray the second or third season. Buds about $2 \mathrm{~mm}$. long, round-ovoid, glabrous and shiny, gray; the stipules caducous. Leaves deciduous, thin but firm, 8 to 12 or rarely even $16 \mathrm{~cm}$. long, 2 to usually 3 or $4 \mathrm{~cm}$. broad, lanceolate, apex attenuately tapered, base cuneate or rounded but narrowly decurrent, coarsely toothed or merely aristate, the teeth with long aristae, margins not revolute, somewhat crisped, both surfaces glabrous and lustrous, the lower somewhat cupreous; veins about 10 or 12 on each side with occasional intermediates, obscurely branching and anastomosing but passing into the teeth, rather prominently raised on both surfaces (including the reticulum); petioles 20 to usually 25 or even $30 \mathrm{~mm}$. long, 0.5 to $1 \mathrm{~mm}$. thick, prominently winged distally, glabrous. Catkins? Styles with

\footnotetext{
${ }_{16}$ Quercus paxtalensis sp. nov.-Ramuli 1-2 mm. crassi glabri, gemmae $2 \mathrm{~mm}$. longae rotundato-ovoideae glabrae, folia decidua $8-16 \mathrm{~cm}$. ionga $2-4 \mathrm{~cm}$. lata lanceolata attenuato-acuta basi cuneata vel rotundata crasse aristato-dentata glabra nitida subtus cupreata, petioli $2-3 \mathrm{~cm}$. longi $0.5-1 \mathrm{~mm}$. crassi glabri, fructus annuus brevipedunculatus, cupula $12-13 \mathrm{~mm}$, lata $8-9 \mathrm{~mm}$. alta, squamae arcte appressae.
} 
abruptly dilated stigmas. Fruit annual, rather small, solitary or paired on a peduncle 2 to $5 \mathrm{~mm}$. long; cups 12 or $13 \mathrm{~mm}$. broad, 8 or $9 \mathrm{~mm}$. high, turbinate or cup-shaped, the base strongly constricted, margins not inrolled, the scales ovate, the narrowed apex rounded and rather closely appressed, gray-tomentulose and partially glabrescent; acorns about 12 or $13 \mathrm{~mm}$. long, $10 \mathrm{~mm}$. broad, ovoid, obtuse at apex, from finely pubescent becoming glabrate and light brown, about onefourth or one-third included (immature fruits merely smaller and the nuts more pointed, not obviously juvenile). (See pl. 113.)

Range: Chiapas, Mexico.

Quercus paxtalensis is distinguished from the other annual-fruited Central American species of the series Acutifoliae by its strictly glabrous leaves and very slender petioles.

Specimens examined:

MEXICO.-Chiapas: Mount Paxtal [misspelled "Pasitar" on the labels], August 3-4, 1937, Matuda 1724 (AA, DeP, Mi [3] [including the type], US, USNA).

\section{Quercus anglohondurensis sp. nov. ${ }^{17}$}

Medium-sized or large tree. Twigs 1 to $2.5 \mathrm{~mm}$. thick, fluted, from loosely fulvous-tomentose soon glabrate and dark reddish brown with rather prominent light lenticels, becoming gray. Buds 2 to $3 \mathrm{~mm}$. long, ovoid, glabrate, rather dull brown or grayish brown and lustrous; the broad ligulate stipules soon caducous. Leaves evergreen or appearing deciduous, rather thin but firm, 7 to usually 10 or even 16 $\mathrm{cm}$. long, 2 to usually 3.5 or even $5 \mathrm{~cm}$. broad, lanceolate or ellipticlanceolate, attenuately acute at apex, base attenuately cuneate or merely cuneate or sometimes rounded, low-toothed or merely aristate from the margin, in any event the teeth long-aristate-tipped, margins minutely revolute and somewhat crisped, both surfaces glabrate and shiny or stellate-pubescent along the midrib especially in the axils of the veins beneath; veins about 10 or 12 on each side, often with evanescent intermediates, branching and rather obscurely anastomosing but passing into the teeth, rather prominent on both surfaces (including the fine reticulum); petioles 5 to $16 \mathrm{~mm}$. long, 1 to $1.5 \mathrm{~mm}$. thick, prominently winged nearly the whole length, from loosely fulvoustomentose becoming glabrate. Staminate catkins? Pistillate catkins 5 to $10 \mathrm{~mm}$. long, 1 - or 2-flowered on glabrous peduncles with conspicuous light lenticels, the elongate styles with abruptly dilated stigmas. Fruit annual, solitary or paired on a peduncle 4 to $8 \mathrm{~mm}$. long; cups 13 to $16 \mathrm{~mm}$. broad, 10 or $11 \mathrm{~mm}$. high, turbinate or deeply cupshaped, the base somewhat constricted, margin not inrolled, scales ovate, the narrowed apex rounded, closely appressed, minutely fulvouspuberulent or the brown margins glabrate; acorns (immature) 10 to $13 \mathrm{~mm}$. broad, about as long, transiently buff-puberulent, probably about one-half included at maturity. (See pls. 114 and 115.)

Range: British Honduras (about 1,000 m.).

Quercus anglohondurensis is distinguished from the other annualfruited species of the series by its low, aristate teeth combined with its usually long petioles and its rather promptly glabrate twigs.

\footnotetext{
${ }^{7}$ Quercus anglohondurensis sp. nov.-Arbor mediocris vel grandis, ramuli 1-2.5 mm. crassi glabrati, gemmae $2-3 \mathrm{~mm}$. longae ovoideae, stipulae late ligulatae mox caducae, folia decidua vel sempervirentia $7-16$ $\mathrm{cm}$. longa $2-5 \mathrm{~cm}$. lata lanceolata utrinque attenuato-acuta vel basi rare rotundata dentata vel aristata glabrata vel costa subtus interdum pubescente, petioli 5-16 mm. longi glabrati, fructus annuus brevipedunculatus, cupula $13-16 \mathrm{~mm}$. lata $10-11 \mathrm{~mm}$. alta, squamae stricte appressae.
} 
Specimens examined:

BRITISH HONDURAS.-Guatemala-British Honduras Boundary Survey, camp 36, May 22, 1934, Schipp 1249 (AA, F, MBG, Mi, NY). El Cayo DisTRICT: along Rio Frio, San Agustin, Mountain Pine Ridge, July-August 1936, Lundell 6615 (F, MBG, Mi [type], NY, US, USNA).

\section{Quercus gracilior sp. nov. ${ }^{18}$}

Large tree. Twigs 1 to $1.5 \mathrm{~mm}$. thick, fluted, from loosely tomentose becoming glabrate and dark reddish brown with small light lenticels. Buds about $3 \mathrm{~mm}$. long, ovoid, acute, glabrous and lustrous light brown; the narrowly ligulate stipules 5 to $10 \mathrm{~mm}$. long, persistent for a time. Leaves deciduous, thin and membranous, 6 to usually 10 or $12 \mathrm{~cm}$. long, 1 to usually 2 or $3 \mathrm{~cm}$. broad, linear-lanceolate or oblanceolate, attenuately acute at both ends, entire except for several low aristate-tipped teeth near the apex, margins very minutely revolute and slightly crisped, glabrous and somewhat shining on both surfaces; veins about 15 on each side with rather strong intermediates, repeatedly branching and rather obviously anastomosing, rather prominent on both surfaces (including the very fine reticulum), the principal ones more strongly raised below; petioles 1 to $3 \mathrm{~mm}$. long, prominently winged, glabrate. Staminate catkins? Pistillate catkins subsessile, 1- or 2-flowered, the elongate styles with very abruptly dilated stigmas. Fruit annual, solitary or paired, subsessile; the young cups not constricted at the base, scales ovate, apex rounded, very closely appressed, fulvous-puberulent but the brown margins glabrate; mature cups and acorns not seen. (See pl. 116.)

Range: Central Honduras (about 1,200 m.).

The short petioles and narrow leaves attenuately acute at both ends and numerous branching veins set this species off from all others in the series Acutifoliae.

Specimens examined:

HONDURAS.-Dept. Comayagua: Coyocutena, San Luis, May 24, 1932 , Edwards 285 (AA [type], F).

Series Crispipiles Trel., Mem. Nat. Acad. Sci, 20: 183. 1924.

Medium-sized or large tree; twigs slender or moderate, glabrate or tomentose; buds ovoid to fusiform, pubescent or glabrate, stipules caducous; leaves evergreen or apparently deciduous, thick or thin but firm, medium-sized, oblong to obovate or lanceolate, rounded to acuminate at apex, rounded to subcordate at base, entire or coarsely toothed, persistently crisped-stellate-tomentose beneath or rarely nearly glabrate; petioles moderately long; fruit biennial, short-pedunculate, solitary or several, cups hemispheric or turbinate, the margins finely or coarsely inrolled, acorns one-half or more included.

Range: Guatemala and Chiapas, Mexico.

Includes: Q. crispipilis Trel. (type).

45. Quercus crispipilis Trel., Mem. Nat. Acad. Sci. 20: 184. pl. 370. 1924.

Quercus cerifera Trel., Mem. Nat. Acad. Sci. 20: 184. pl. 370. 1924.

18 Quercus gracilior sp. nov.-Arbor grandis, ramuli 1-1.5 mm. crassi glabrati; gemmae $3 \mathrm{~mm}$. longae ovoideae glabratae, stipulae $5-10 \mathrm{~mm}$. longae anguste ligulatae interdum persistentes, folia decidua $6-12 \mathrm{~cm}$. longa 1-3 cm. lata linearilanceolata utrinque attenuato-acuta prope apicem aristato-dentata alibi integra, venis utrinque 15 anastomosantibus, petioli 1-3 mm. longi alati, fructus annuus. 
Q. cinnamomea Trel., Mem. Nat. Acad. Sci. 20: 184. pl. 371. 1924.

Large or medium-sized tree. Twigs 1.5 to 2 or $3 \mathrm{~mm}$. thick, subterete or fluted, dark reddish brown, sparsely or densely buff-stellatetomentose, glabrate with few scarcely prominent lenticels, grayish the second season. Buds scarcely $2 \mathrm{~mm}$. long, round-oroid, glabrous or the scales ciliate, brown; stipules caducous. Leaves evergreen, thin but firm and somewhat chartaceous, 3 to usually 8 or eren $12 \mathrm{~cm}$. long, 1 to usually 2 or $3 \mathrm{~cm}$. broad, oblong-elliptic to oblong-lanceolate or rarely oblanceolate, apex acute or usually rounded, in either event aristate-tipped, base rounded or subcordate, rarely subcuneate, entire, the margins minutely rerolute and often rather coarsely undulatecrisped, upper surface rather dull, glabrous or stellate-pubescent about the base of the midrib, lower surface dull or somewhat shiny, inconspicuously low-bullate or smooth, more or less densely buff-stellatetomentose, the hairs rather markedly curly, tardily glabrate or persistently hairy, some forms rather sparingly tomentose; reins 12 to 15 or eren 20 on each side, often with intermediates, much branched and obriously anastomosing toward the margin, slightly if at all impressed abore, the reticulum slightly raised, rather prominent beneath with the reticulum less so; petioles 2 to usually 5 or even $7 \mathrm{~mm}$. long, tomentose or glabrate with the leaves. Catkins? Fruit biennial, solitary, paired, or several on a peduncle 2 to 7 or rarely $10 \mathrm{~mm}$. long; cups about $12 \mathrm{~mm}$. broad, $10 \mathrm{~mm}$. high, turbinate with a constricted base, the margins inrolled, scales orate-lanceolate, apices rounded, rather closely appressed, canescent-pubescent; acorns about $12 \mathrm{~mm}$. long, $8 \mathrm{~mm}$. broad, glabrous or slightly silky, light brown, about onehalf or two-thirds included. (See pls. 117 and 118.)

Range: Chiapas, Mexico, and northern Guatemala.

Quercus crispipilis represents one of the most utterly confusing problems in the study of Central American Quercus. Trpical material, taken alone, would seem to constitute a distinct species with clear-cut characters. Similarly, the specimens that have been described as Q. skutchii, Q. chicharacana, Q. pannosifolia, etc., would seem, at least in the aggregate, to represent a distinct species if not a homogeneous one. Howerer, between these two groups there occur surprising intermediates. For instance, what has been called $Q$. cinnamomea has some of the characters of Q. crispipilis but the thick tomentum of the pannosifolia aggregation. The more fundamental characters are identical throughout this entire complex, but the pannosifolia relationship mar be distinguished as a rariety with usually thicker and more dense and often persistent tomentum, less constantly entire leares, and a lower leaf surface usually granular-bullate. The problem is also further complicated by a relationship between the variety and Q. candicans Nee, which is discussed below.

Specimens examined:

MEXICO.-Chiapas: Canjob, April 30, 1904, Goldman 919 (US); Comitan, June 12, 1906, Cook 99 (US); between Comitan and Bajucuc, June 14, 1906, Cook 109 (US); between Bajucuc and Mendoza, June 15, 1906, Cook 116 (US [type of Q. cerifera]); Las Casas, February 1939, Martinez 364 (USNA); April 1939, Martinez 365 (USNA); July 1940, Martinez 386 (USNA).

GuATemala.-Dept. Huenuetenango: Uaxac Canal, August 23, 1896, Seler 2667 (G [isotype]); Huehuetenango, January 14, 1939, Standley 62593 (F, USNA); $10 \mathrm{~km}$. east of Huehuetenango toward Aguacatan, January 2, 1941, Standley 82108 (USNA); mountains west of Aguacatan toward Huehuetenango, 
December 27, 1940, Standley 81278 (USNA) ; river southeast of Chiantla, January 6, 1941, Standley 82459 (USNA); about Laguna de Ocubila, east of Huehuetenango January 7, 1941, Standley 82672 (USNA). Dept. Quezaltenango: Quezaltenango, 1922, Hurter 1 (Ill); mountains above Olintepeque, February 20, 1939, Standley 65965 (F, USNA). Dept. Totonicapan: near San Francisco El Alto, January 12, 1941, Standley 83133 (USNA). DePt. Quiche: between Quiche and Totonicapan, May 16, 1906, Cook 27 (US [type of Q. cinnamomea]); south of Chichicastenango, January 11, 1939, Standley 62412 (F, USNA); between Quiche and San Pedro Jocopilas, January 12, 1939, Standley 62452 (F, USNA). Dept. Chimaltenango: Barranco de la Sierra, southeast of Patzum, December 31, 1938, Standley 61611 (F, USNA).

45a. Quercus crispipilis var. pannosifolia (C. H. Mull.) comb. nov.

Quercus brachystachys f. venulosa Trel., Mem. Nat. Acad. Sci. 20: 130. pl. 240.1924.

Q. brachystachys f. caerulea Trel., Mem. Nat. Acad. Sci. 20: 130. pl. 240.1924.

Q. skutchii Trel., Journ. Wash. Acad. Sci. 23: 61. 1933.

Q. chichavacana Trel., Jourm. Wash. Acad. Sci. 23: 62. 1933.

Q. chimaltenangana Trel., Journ. Wash. Acad. Sci. 23: 62. 1933.

Q. aristigera Trel., Journ. Wash. Acad. Sci. 23: 63. 1933.

Q. skutchii f. oblanceolata C. H. Mull., Amer. Midl. Nat. 18: 852. 1937.

Q. skutchii f. sublobata C. H. Mull., Amer. Midl. Nat. 18: 852. 1937.

Q. skutchii f. undulata C. H. Mull., Amer. Midl. Nat. 18: 852. 1937.

Q. pannosifolia C. H. Mull., Amer. Midl. Nat. 18: 855. 1937.

Medium-sized or large tree. Twigs 1.5 to 2 or $3 \mathrm{~mm}$. thick, fluted or subterete, dark reddish brown with usually conspicuous lenticels, from more or less densely stellate-tomentose promptly or tardily glabrate or persistently tomentulose. Buds 4 to $5 \mathrm{~mm}$. long, 1.5 to 2.5 $\mathrm{mm}$. broad, fusiform or ovoid, from pubescent becoming glabrate; stipules caducous. Leaves apparently deciduous, thick and firm, 3 to usually 8 or 10 or even $14 \mathrm{~cm}$. long, 1.5 to usually 4 or even $6 \mathrm{~cm}$. broad, oblong-elliptic to obovate or oblanceolate, rarely lanceolate, usually broadest above the middle, rounded to acute or exceptionally acuminate at apex, in any event aristate-tipped, cuneate to rounded, truncate, or cordate at base, entire to coarsely several-toothed or sublobate, the lobes broadly rounded but aristate-tipped, usually merely undulate or few-toothed toward the apex, the margins often coarsely crisped, minutely or coarsely revolute, upper surface somewhat shining, from sparsely stellate soon glabrate or persistently pubescent about the base of the midrib, lower surface dull, from densely velvetystellate-tomentose with buff or tan curly hairs subglabrate or persistently flocculent or velvety, the denuded surface (of mature leaves) low- or granular-bullate; veins 9 to 12 or 15 on each side, branched and anastomosing near the margin, impressed above, quite prominent beneath; petioles 4 to usually 10 or $12 \mathrm{~mm}$. long, 1 to $2 \mathrm{~mm}$. thick, glabrate or persistently tomentose with the leaves. Staminate catkins 8 to $10 \mathrm{~cm}$. long, curly-stellate-villous, sparsely flowered, the anthers well exserted. Pistillate catkins 5 to $15 \mathrm{~mm}$. long, 1 - or 2 flowered. Fruit biennial, solitary or paired on a coarse glabrous peduncle 3 to $10 \mathrm{~mm}$. long and 4 to $6 \mathrm{~mm}$. thick with large prominent lenticels; cups 12 to $20 \mathrm{~mm}$. broad, 10 to $12 \mathrm{~mm}$. high, hemispheric to 
cup-shaped or turbinate, the margins finely inrolled or coarsely inrolled and inflated, the scales oblong to ovate, truncate at apex, rather loosely appressed, sparsely gray-appressed-pubescent; acorns ovoid to subelliptic, 15 to $18 \mathrm{~mm}$. long, 10 to $14 \mathrm{~mm}$. broad, glabrous, light brown, about one-half or more included. (See pls. 119 to 122.)

Range: Mountains of western and central Guatemala and Chiapas.

This polymorphic variety is fairly constant in its fruiting characters and in the thickness of the impressed-veiny leaves and their more or less granular-bullate lower surface. These characters seem to distinguish the variety amply from the species with which it is identical in fruit characters and in the kind, if not the degree, of pubescence. The various proposed species based on forms of this variety differ only in leaf size, leaf shape, and persistence of pubescence. It would serve no purpose to recognize them and the several additional ones that consistency would demand.

The form that has been called Q. chimaltenangana shows a degree of relationship to Q. candicans Nee in leaf size and shape. Only the larger leaves, short-appressed-stellate pubescence of the under leaf surface, and the rather constantly aristate-toothed margins of the latter species would distinguish it from the chimaltenangana form. Q. brachystachys $\mathrm{f}$. venulosa does suggest $Q$. brachystachys in its rather persistentlv stellate twigs, but that character is common in the var. pannosifolia. The thinnish leaves of $f$. venulosa with rather thin curly stellate tomentum beneath definitely identify it with the var. pannosifolia. Q. brachystachys f. caerulea is clearly identical with the type of var. pannosifolia.

Specimens examined:

MEXICO.-ChIAPAs: Las Casas, San Cristobal, February 1939, Martinez 3\%0 (USNA)

GUATEMAla.-Dept. Quezaltenango: Quezaltenango, April 7, 1915, Trelease 28 (Ill [2] [type of Q. brachystachys f. venulosa]); Trelease 29 (Ill); April 6, 1915, Trelease 30 (III [4] [type of Q. brachystachys f. caerulea]); Volcan Santa Maria above Palojunoj, March 6, 1939, Standley 67531 (F, USNA). Dept. Quiche: Nebaj, November 15, 1934, Skutch 1653 (AA, F [2]). Dept. Chimaltenango: Chichavac, November-December 1930, Skutch 44 (US [type of Q. skutchii]); Skutch 5\% (US [type of Q. chichavacana]); Skutch 61 (Ill, US); Skutch 62 (Ill, US [type of Q. chimaltenangana]); Skutch 86 (Ill, US [type of Q. aristigera]); March 11, 1933, Skutch 324 (US); March 12, 1933, Skutch 326 (US); November 11, 1933, Skutch 681 (US [type of Q. chichavacana f. oblanceolata]); Skutch 682 and 683 (US); November 14, 1933, Skutch 689 (US [type of Q. chichavacana f. undulata]) ; November 19, 1933, Skutch 698 (Ill [type of Q. pannosifolia], US); November 27, 1933, Skutch 712 (US [isotype of Q. chichavacana f. sublobata]); November 29, 1933, Skutch 727 (US). DEPT. Chimaltenango: Barranco de la Sierra, southeast of Patzum, December 31, 1938, Standley 61532, 61543, and 61607 (F, USNA). Dept. Guatemala: Finca La Aurora, 1940, Aguilar 447 (F); near San Juan Sacatepequez, December 8, 1938, Standley 59247 (F, USNA).

Series Calophyllae Trel., Mem. Nat. Acad. Sci. 20: 202. 1924.

Medium-sized or large trees; twigs rather coarse, glabrate or persistently tomentose; buds ovoid to subfusiform, stipules caducous; leaves large, characteristically obovate, usually aristate-toothed, densely short-tomentose beneath; petioles moderately long; fruit biennial, short-pedunculate, solitary or paired, cups hemispheric, acorns about one-third included.

Range: Guatemala and the proximal ends of both the eastern and western Sierra Madre of Mexico. 
Includes: Q. candicans Nee (including Q. calophylla Schlecht. and Cham., the type).

This series is amply distinct in its broad leaves characteristically obovate, aristate-toothed, and short-tomentose beneath, but this distinction is occasionally obscured in a variant of Q. crispipilis var. pannosifolia.

46. Quercus candicans Nee, Anal. Cienc. Nat. 3: 277. 1801.

Q. calophylla Schlecht. and Cham., Linnaea 5: 79. 1830.

Q. chimaltenangensis f. gemmata C. H. Mull., Amer. Midl. Nat. 18: 855. 1937 (pro parte-type only).

Large tree. Twigs 2.5 to usually 4 or $5 \mathrm{~mm}$. thick, coarsely fluted, glabrate or rather persistently short-stellate-tomentose especially in the grooves, dark reddish brown becoming grayish, with numerous rather large light lenticels or these not evident until the second season. Buds 5 or $6 \mathrm{~mm}$. long, 2 or $3 \mathrm{~mm}$. broad, very acute (or only $3 \mathrm{~mm}$. long and broadly ovoid if young), dull brown, the scales ciliate or glabrous; stipules caducous. Leaves deciduous, rather thin but firm and hard, about 10 to usually 15 or even $23 \mathrm{~cm}$. long, 4 to usually 8 or even $14 \mathrm{~cm}$. broad, characteristically obovate to sometimes ellipticoblong but broadest above the middle, apices acuminate and aristatetipped or rarely the tip finally rounded, bases cordulate or truncate, undulate-margined to usually coarsely toothed with long aristate tips, the margins very minutely revolute, upper surface glabrate or rather pubescent along the base of the midrib, somewhat shining, lower surface persistently and densely short-buff-tomentose with matted stellate hairs but the midrib and principal veins glabrous; veins 8 to 10 or even 14 on each side, branching and anastomosing but ultimately passing into the teeth, somewhat impressed above but raised within the grooves, quite prominent beneath; petioles 15 to 20 or even 40 (rarely only 6 ) $\mathrm{mm}$. long. 1.5 to $2 \mathrm{~mm}$. thick, glabrate or tomentose with the twigs. Staminate catkins (in Mexican material) 5 to $6 \mathrm{~cm}$. long, villous, loosely flowered, the apiculate anthers somewhat exserted. Pistillate catkins 1.5 to $2 \mathrm{~cm}$. long, 2- or 3 -flowered. Fruit biennial, solitary or paired on a coarse peduncle 8 to $12 \mathrm{~mm}$. long and 4 to $6 \mathrm{~mm}$. thick with numerous large prominent lenticels; cups 16 to $20 \mathrm{~mm}$. broad, 10 to $12 \mathrm{~mm}$. high, hemispheric or deeper, margins inrolled or not, scales ovate to lanceolate, thin, closely or somewhat loosely appressed, apices rounded, canescent all over except the glabrous and brown regular narrow margins; acorns about 15 to $18 \mathrm{~mm}$. long, 11 to $14 \mathrm{~mm}$. broad, ovoid, from silky-puberulent becoming glabrate and light brown, about one-third included. (See pls. 123 and 124.)

Range: Guatemala $(1,500$ to $2,000 \mathrm{~m}$.) and mountains of southcentral Mexico; type from Tixtla, Mexico (Nee).

Quercus candicans was described by Nee on the basis of juvenile material from the Sierra Madre Occidental of Mexico. Trelease points out that the type is not representative of the species and that the new forms he proposes bear the same relationship to the type that Q. calophylla bears to one of its juvenile forms. There seems to be no adequate distinction between $Q$. candicans and $Q$. calophylla. $Q$. chimaltenangensis f. gemmata cannot now be maintained distinct from $Q$. candicans, although its narrow leaves and inrolled cup are suggestive of the chimaltenangana element of the complex here called 
Q. crispipilis var. pannosifolia. The relationship between that complex and Q. candicans is fairly evident. Q. candicans is distinguished by its characteristically large broadly obovate leaves with coarse aristate-tipped teeth and fine rather appressed-stellate-tomentose under surfaces.

Numerous forms have been named from Mexican material under both Q. candicans and Q. calophylla. Since these names do not affect the Central American representation of the species, they are not included in the synonymy.

Specimens examined:

GUATEMala.-Dept. Huehuetenango: $10 \mathrm{~km}$. east of Huehuetenango toward Aguacatan, January 2, 1941, Standley 82170 (USNA); 13-14 km. east of Huehuetenango toward Aguacatan, January 2, 1941, Standley 81976 (USNA); near crossing of Rio San Juan Ixtan east of San Rafael Petzal, January 9, 1941, Standley 83017 and 83021 (USNA). Dept. QUiche: Nebaj, November 15, 1934, Skutch 1654 (AA, F [2], Ill [type of Q. chimaltenangana f. gemmata], NY); Skutch 1655 (AA, Ill); Skutch 1656 (AA, F, Ill). Dept. JALAPA: near Minas de Croma, above Potrero Carillo, 13 miles northeast of Jalapa, December 12, 1939, Steyermark 83113 (F, USNA).

\section{EXCLUDED SPECIES}

Quercus exaristata Trel., fide C. H. Mull., Amer. Midl. Nat. 18: 853. 1937-misidentification of Q. sapotaefolia Liebm.

Q. subcrispata Trel., fide C. H. Mull., Amer. Midl. Nat. 18: 854. 1937-misidentification of Q. tristis Liebm.

Q. dawsoni Trel. in Yuncker, Field Mus. Bot. Ser. 17: 357. 1938 - not Fagaceae.

Q. pertessellata Trel. in Yuncker, Field Mus. Bot. Ser. 17: 357. 1938 - not Fagaceae. ${ }^{19}$

\section{LIST OF EXSICCATAE ${ }^{20}$}

Aguilar, I.

160. Q. conspersa.

211. Q. tristis.

215. Q. skinneri.

242, 243. Q. tristis.

291. Q. acatenangensis.

321. Q. segoviensis.

344. Q. conspersa.

424. Q. sapotaefolia.

444. Q. brachystachys.

447. Q. crispipilis var. pannosifolia.

448. Q. brachystachys.

449. Q. acatenangensis.

497. Q. skinneri.

Allen, P. H.

302. Q. gulielmi-treleasei.

303. Q. oocarpa.

672. Q. costaricensis.

1595. Q. seemanni.

1596. Q. seibertii.

Allen, P. H.- see also Woodson, R. E.,

Allen, P. H., and Seibert, R. J.
ANDRe, E.

171, 1433. Q. humboldtii.

Bartlett, H. H.

11203, 11308, 11313, 11552, 11553. Q. oleoides.

11656. Q. peduncularis var. sublanosa.

11873, 11886, 12112, 12976, 12979. $Q$. oleoides.

BEQUAERT, J.

40. Q. corrugata.

BLAKE, S. F.

7449. Q. hondurensis.

7735. Q. oleoides.

Brenes, A. M.

$5178,5194,5566,6010,6224$ Q Q brenesii.

6704. Q. borucasana.

11602. Q. brenesii.

13437. Q. pilarius.

14520. Q. brenesii.

15590. Q. oleoides.

16966. Q. brenesii.

19 The sterile types of both Q. dawsoni and Q. pertessellata (and several other unpublished species) have been examined, and they clearly exhibit vegetative characters (particularly the buds and, in some, translucent glands in the leaf blades) which exclude them from the Fagaceae.

20 Numbers cited are collectors' numbers; when these are lacking, dates (in italics) are substituted if available. 
Calderon, S.

1430. Q. vincentensis.

1981. Q. skinneri.

2428. Q. corrugata.

2429 , p. p. Q. skinneri.

2429 , p. p. Q. boqueronae.

2443. Q. sapotaefolia.

2444. Q. hondurensis.

2445. Q. peduncularis var. sublanosa.

2446. Q. peduncularis.

2447 , p. p. Q. hondurensis.

2447 , p. p. Q. sapotaefolia.

2508, 2510. Q. hondurensis.

Collins, G. N., and Doyle, C. B.

118. Q. conspersa.

Cook, O. F.

13. Q. peduncularis.

14. Q. conspersa.

15. Q. purulhana.

25. Q. brachystachys.

27. Q. crispipilis.

28. Q. acatenangensis.

30. Q. brachystachys.

78, 79. Q. sebifera.

99, 109, 116. Q. crispipilis.

220. Q. оосаrpa.

236. Q. sapotaefolia.

247. $Q$. conspersa.

266. Q. purulhana.

278, 288. Q. conspersa.

Cook, O. F., and Doyle, C. B.

280. $\dot{Q}$. peduncularis var. sublanosa.

282. Q. conspersa.

285. Q. purulhana.

286. Q. peduncularis var. sublanosa.

Coøк, O. F., and Griggs, R. F.

318. Q. oleoides.

569, 571. Q. corrugata.

572. Q. oocarpa.

607. Q. flagellifera.

615. Q. skinneri.

Cuatrecasas, J.

113, 8784, 9076. Q. humboldtii.

Cuatrecasas, J.- see also Perez Arbaelez, E., and Cuatrecasas, J.

DANIEL, Bro.

384. Q. humboldtii.

Davidson, Mrs. M. E.

437. Q. seemanni.

497. Q. oocarpa.

677, 721, 780. Q. seemanni.

864. Q. davidsoniae.

909. Q. seemanni.

Davidson, Mrs. M. E.-see also Terry, Mrs. M. E.

DAWE, M. T. 55, 798. Q. humboldtii.

Dawson, R. F. see Yuncker, T. G., Dawson, R. F., and Youse, H. R.

DeAm, C. C. 159. Q. oleoides.

6087, 6218. Q. conspersa.

6231. Q. peduncularis.
Dodge, C. W., and Thomas, W. S. 6232. Q. oleoides.

Doyle, C. B.- see Collins, G. N., and Doyle, C. B.-also Cook, O. F., and

Doyle, C. B.

Dryander, Frau E. 2079. Q. humboldtii.

DuQue, J. M. 567. Q. humboldtii.

EDWARDs, J. B. 18. Q. aáata.

185. Q. hondurensis.

285. Q. gracilior.

$323,375,578 . \quad Q$. oleoides.

Friedrichsthal, E.

Galusser, $\mathrm{C}$. Q. oleoides.

1. Q. oleoides.

Garcia Barriga, H. 4853, 7746. Q. humboldtii.

Gentle, P. H. 2695, 3378. Q. eleoides.

Goldman, E. A. 919. Q. crispipilis. 1054. Q. conspersa.

Griggs, R. F.- see Cook, O. F., and Griggs, R. F.

Hagen, C. von, and Hagen, W. von. 1011. Q. corrugata.

1038. $Q$. peduncularis var. sublanosa.

1045. Q. hondurensis.

1095. Q. oleoides.

1133, 1206. Q. peduncularis var. sublanosa.

1219. Q. conspersa.

1220. Q. sapotaefolia.

1246. Q. conspersa.

HarTwEG, K. T.

563. Q. benthami.

564. Q. peduncularis.

615. Q. skinneri.

616. Q. peduncularis.

617. Q. conspersa.

1393 Q. humboldtii.

Q. skinneri.

Hатсн, W. R., and Wilson, C. L.

307. Q. peduncularis.

$\mathrm{H}_{A Y}, \mathrm{R}$. - see MAXON, W. R., and HAY, R

HAYES, S.

830. Q. humboldtii.

July 30, 1860. Q. brachystachys.

July 1860. Q. conspersa.

July 1860. Q. tristis.

July 1860. Q. sapotaefolia.

July 1860. Q. peduncularis.

Hazen, T. E.-see Killip, E. P., and HAZEN, T. E.

HEYDE, E. T.

1. Q. conspersa.

Heyde, E. T., and Lux, E.

3151. Q. conspersa.

3152 , p. p. Q. brachystachys.

3152 , p. p. Q. peduncularis.

3154. Q. conspersa. 
Hurter, G. I.

1. Q. crispipilis.

2. Q. acatenangensis.

$3,3 \mathrm{~b}, 4,5,6,7,8,9$. Q. pilicaulis.

Jimenez, L. O.

1086. Q. seemanni.

Johnston, J. R.

514. Q. brachystachys.

520. Q. acatenangensis.

997. Q. tristis.

Kellerman, W. A.

4826, 4828. Q. acatenangensis.

4833. Q. tristis.

5028. Q. conspersa.

5151. Q. acatenangensis.

5658. Q. peduncularis.

5922. Q. pilicaulis.

6061. Q. skinneri.

6442. Q. brachystachys.

6443, 6497. Q. acatenangensis.

6563. Q. tristis.

7032. Q. peduncularis.

7707. Q. sapotaefolia.

7790. Q. conspersa.

8043. Q. peduncularis.

Kelly, J.

163. Q. sapotaefolia.

Killip, E. P., and Hazen, T. E. 9024. Q. humboldtii.

Killip, E. P., and Smith, Albert C. 15296, 15895, 16744, 18267, 19078. Q. humboldtii.

Killip, E. P.-see also Pennell, F. W., and Killip, E. P.

KinLOCH, J. B. 97. Q. oleoides.

Koepper, J. M.-see Yuncker, T. G., KOEPPER, J. M., and WAGNER, K. A.

Kuntze, O.

2282 , p. p. Q. costaricensis. 2282 , p. p. Q. copeyensis.

2344. Q. irazuensis.

2352. Q. costaricensis.

Kurlen, H.- see Record, S. J., and KuYlen, H.

LANKESTER, C. H. 241. Q. corrugata.

Lehmann, F. C. 3560, 3899. Q. humboldtii.

Lewis, Mrs. B. B. 305. Q. conspersa.

Lewis, M.

1117, 1118. Q. conspersa.

September 1939. Q. piliarus.

LINDEN, J. J. 1325. Q. humboldtii.
Lundell, C. L.

4347. Q. oleoides.

6615. Q. anglohondurensis.

6626. Q. peduncularis var. sublanosa.

6627. Q. oleoides.

6729. Q. peduncularis var. sublanosa.

6758. Q. hondurensis.

6837, 6964. Q. oleoides.

Lux, E.- see Heyde, E. T., and Lux, E.

Martinez, M. ${ }^{21}$

363. Q. acatenangensis.

364, 365. Q. crispipilis.

366. Q. brachystachys.

367,368 . Q. pilicaulis.

369. Q. acatenangensis.

370. Q. crispipilis var. pannosifolia.

371. Q. acatenangensis.

372. Q. tristis.

373. Q. peduncularis.

374, 375. Q. oleoides.

376. Q. tristis.

377. Q. acatenangensis.

378,379 . Q. pilicaulis.

380. Q. acatenangensis.

383. Q. skinneri.

384. Q. brachystachys.

385. Q. peduncularis.

386. Q. crispipitis.

387. Q. oleoides.

388. Q. peduncularis.

389. Q. conspersa.

390. Q. pilarius.

391. Q. skinneri.

Matuda, E.

65, 289. Q. duratifolia.

296. Q. acatenangensis.

471. Q. conspersa.

857. Q. duratifolia.

1074. Q. acatenangensis.

1607. Q. peduncularis.

1724. Q. paxtalensis.

1823, 1824. Q. boqueronae.

1827, 1873, 2073, 2102. Q. duratifolia.

2386. Q. benthami.

3129,3732 . Q. oleoides.

3927. Q. conspersa.

3935. Q. benthami.

4232. Q. sapotaefolia.

4234. Q. polymorpha.

4303. Q. peduncularis.

4653, 4748. Q. conspersa.

Maxon, W. R., and Hay, R.

3372. Q. sapotaefolia.

21 The collection of Maximino Martinez was made in part by Martinez and in part by various of his collaborators in the Mexican Government service. No record was kept of the various collectors, and no field collection numbers were applied. The collection was partially numbered, but as often as not the numbers appeared on two or more obviously distinct collections, frequently embracing more than one species and even plants labeled as having grown in widely separated localities. As the citation of such inconsistent numbers must prove confusing and as all the duplicates of the collection were believed to be at hand, it was thought best to apply a completely new series of numbers beginning with 1 . There is every indication that scrupulous care was exercised in recording the localities in which the plants were collected. 
Miller, W. de W., and Griscom, L. 23. Q. peduncularis var. sublanosa.

Morales, R. J.

748. Q. sapotaefolia.

Muenscher, W. C.

12438, $12453 . \quad$ Q. corrugata.

12493. Q. tristis.

12498. Q. brachystachys.

Mutis, J. C.

5103. Q. humboldtii.

Nelson, E. W.

533. Q. conspersa.

3720. Q. acatenangensis.

3721. Q. pilicaulis.

Niemeyer, E.

210. Q. humboldtii.

O'NeILL, H.

8554, 8555. Q. oleoides.

Penneli, F. W.

2640. Q. humboldtii.

Pennell, F. W., and Killip, E. P. 6396, 7244. Q. humboldtii.

Perez Arbaelez, E. 3092. Q. humboldtii.

Perez Arbaelez, E., and CuatreCASAS, J.

5801, 8100. Q. humboldtii.

Pittier, H.

129. Q. conspersa

130. Q. peduncularis.

131. Q. conspersa.

163. Q. purulhana.

871. Q. costaricensis.

1789, 1818. Q. oleoides.

1869. Q. corrugata.

2036. Q. sapotaefolia.

2197. Q. corrugata.

2262. Q. seemanni.

2607. Q. oleoides.

5305. Q. seemanni.

10553. Q. borucasana.

14120. Q. costaricensis.

February 1891. Q. corrugata.

Popenoe, W.

681. Q. brachystachys.

685. Q. tristis.

726. Q. sapotaefolia.

Purpus, C. A.

91. Q. peduncularis.

97, 416. Q. sapotaefolia.

6997. Q. boqueronae.

6998. Q. corrugata.

6999, 6999'. Q. skinneri.

10091, 10824. Q. monserratensis.

QUiros, M.

187. Q. brenesii.

Record, S. J., and KuYLen, H.

53, 53A. Q. oleoides.

Reeves, E.

$1,2,3$. Q. skinneri.

4. Q. crispifolia.

5,6. Q. skinneri.

7. Q. crispifolia.

$8,9,10 . \quad Q$. skinneri.

February 1918. Q. corrugata.

RODRIGUEZ, J. J.

3636. Q. skinneri.

Rojas, U.
$367 . \quad$ Q pilicaulis.

Rowlee, W. W., and STork, H. E.

940. Q. costaricensis.

Salas, G.

13. Q. skinneri.

203. Q. tristis.

Schery, R. W.-see Woodson, R. E., and Schery, R. W

Sсhipp, W. A.

209. Q. oleoides.

663. Q. sapotaefolia.

672. Q. oleoides.

1247, 1248. Q. insignis.

1249. Q. anglohondurensis.

Seemann, B. C.

Seibert, R. J.

$$
\text { Q. seemanni. }
$$

225. Q. seibertii.

226. Q. gulielmi-treleasei.

317. Q. oocarpa.

1619. Q. costaricensis.

Seibert, R. J.-see also Woodson, R.

E., Allen, P. H., and Seibert, R. J.

Seler, C., and Seler, E.

2583. Q. conspersa.

2667. Q. crispipilis.

2668. Q. peduncularis.

3067. Q. polymorpha.

Shannon, W. C.

3648. Q. skinneri.

Skinner, G. U.

3. Q. corrugata.

Sк Uтсн, A. F.

$$
\text { Q. conspersa. }
$$

14. Q. acatenangensis.

44. Q. crispipitis var. pannosifolia.

50. Q. pilicaulis,

53. Q. acatenangensis.

$57,61,62,86$. Q. crispipilis var. pannosifolia.

252. Q. acatenangensis.

296. Q. pilicaulis.

315. Q. conspersa.

324, 326, 681, 682, 683. Q. crispipilis var. pannosifolia.

661. 684, 685, 686, 687, 688. $Q$ pilicaulis.

689. Q. crispipilis var. pannosifolia.

691. Q. acatenangensis.

692, 693. Q. benthami.

698, 712, 727. Q. crispipilis var. pannosifolia.

728. Q. pilicaulis.

1072. Q. brachystachys.

1078. Q. pilicaulis.

1105. Q. tristis.

1133. Q. conspersa.

1155. Q. acatenangensis.

1653. Q. crispipilis var. pannosifolia.

1654, 1655, 1656. Q. candicans.

1875. Q. skinneri.

1906. Q. sapotaefolia.

3584. Q. aáata. 
Smith, Albert C.-see Killip, E. P., Standley, P. C.-Continued.

and Smith, Albert C.

Smith, Austin

141, 177. Q. davidsoniae.

198, 370. Q. eugeniaefolia.

464. Q. seemanni.

2742. Q. corrugata.

2756. Q. aáata.

2769. Q. davidsoniae.

2828, 2877. Q. eugeniaefolia.

2878. Q. oоcarpa.

2879. Q. aáata.

Sмiтн, J. D.

1709. Q. skinneri.

1710, 1967. Q. sapotaefolia.

1968. Q. pilicaulis.

2189. Q. brachystachys.

2627. Q. acatenangensis.

2628. Q. brachystachys.

2629. Q. acatenangensis.

2630. Q. skinneri.

Stadtmiller, L. R. - see Whitford, H. N., and Stadtmiller, L. R. Standley, P. C.

20154, 20267. Q. skinneri.

21593. Q. vicentensis.

21599. Q. skinneri.

32619, 33869. Q. oоcarpa.

33875. Q. gulielmi-treleasei.

34181. Q. eugeniaefolia.

34186. Q. davidsoniae.

34395. Q. aáata.

34561. Q. corrugata.

35958, 39798, 41459. Q. oоcarpa.

41611. Q. eugeniaefolia.

41707. Q. corrugata.

42220. Q. eugeniaefolia.

42425. Q. pilarius.

42558. Q. seemanni.

42573, 42583. Q. copeyensis.

42629. Q. aáata.

42834. Q. corrugata.

42842. Q. pilarius.

42876. Q. eugeniaefolia.

42985. Q. seemanni.

42988, 43046. Q. eugeniaefolia.

55930. Q. segoviensis.

56133. Q. hondurensis.

56179. Q. sapotaefolia.

56184. Q. peduncularis var. subtanosa.

56229. Q. hondurensis.

56364, 56393. Q. sapotaefolia.

57912. Q. conspersa.

57918. Q. tristis.

57923. Q. conspersa.

57967. Q. peduncularis.

58065. Q. skinneri.

58311. Q. tristis.

58466. Q. aáata.

58467, 58474. Q. pacayana.

58848. Q. brachystachys.

58886. Q. tristis.

58892. Q. acatenangensis.

59233, 59235. Q. sapotaefolia.
59247. Q. crispipils var. pannosifolia.

59344. Q. acatenangensis.

59440. Q. tristis.

59469. Q. acatenangensis.

59617. Q. pilicaulis.

59741. Q. conspersa.

59742. Q. peduncularis.

59747. Q. conspersa.

59900, 59953. Q. tristis.

59984. Q. acatenangensis.

60102. Q. peduncularis.

60581 . Q. peduncularis var. sublanosa.

60583. Q. tristis.

60588. Q. peduncularis var. sublanosa.

60599. Q. pilicaulis.

60611, 60756. Q. tristis.

60945. Q. pilicaulis.

61140. Q. acatenangensis.

61217. Q. brachystachys.

61224, 61248, 61252. Q. tristis.

61509. Q. pilicaulis.

61532. Q. crispipilis var. pannosifolia.

61542. Q. peduncularis.

61543, 61607. Q. crispipilis var. pannosifolia.

61611. Q. crispipilis.

61627. Q. tristis.

61628. Q. brachystachys.

61696, 61753. Q. tristis.

61761. Q. peduncularis.

61773. Q. acatenangensis.

62127. Q. skinneri.

62362. Q. brachystachys.

62394. Q. acatenangensis.

62395. Q. brachystachys.

62412. Q. crispipilis.

62450, 62451. Q. peduncularis.

62452. Q. crispipilis.

62457. Q. peduncularis.

62458. Q. brachystachys.

62495, 62553. Q. conspersa.

62577. Q. peduncularis var. sublanosa.

62578. Q. brachystachys.

62593. Q. crispipilis.

62607. Q. brachystachys.

62613. Q. conspersa.

62615. Q. brachystachys.

62617. Q. conspersa.

62623. Q. peduncularis var. sub-

lanosa.

62640,62649. Q. acatenangensis.

62862. Q. peduncularis.

62940. Q. sapotaefolia.

62946. Q. peduncularis.

62947. Q. conspersa.

62948. Q. sapotaefolia.

63000. Q. peduncularis.

63001. Q. sapotaefolia.

63002. Q. peduncularis. 
Standley, P. C.-Continued. 63012. Q. conspersa.

63013, 63015. Q. sapotaefolia.

63134, 63183, 63304. Q. tristis.

63322, 63331, 63332. Q. peduncu-

laris var. sublanosa.

63675. Q. tristis.

63687. Q. acatenangensis.

63741. Q. tristis.

63787. Q. acatenangensis.

63854. Q. peduncularis.

63863. Q. brachystachys.

64363, 64371. Q. peduncularis.

64372. Q. tristis.

64401. Q. brachystachys.

64461, 64485. Q. peduncularis.

64487. Q. tristis.

64563. Q. pilarius.

65217. Q. brachystachys

65403. Q. benthami.

65607. Q. brachystachys.

65652. Q. peduncularis.

65653. Q. segoviensis.

65823. Q. peduncularis.

65824, 65827. Q. tristis.

65830. Q. conspera.

65959. Q. acatenangensis.

65960. Q. pilicaulis.

65964. Q. acatenangensis.

65965. Q. crispipilis.

$65966,65974,65975,66083,66100$.

Q. acatenangensis.

66128. Q. pilicaulis.

66203. Q. peduncularis.

66204. Q. acatenangensis.

66205. Q. segoviensis.

66206. Q. pilicaulis.

$66208,66217,66359,66380 . \quad Q$. acatenangenis.

66397. Q. peduncularis.

66403. Q. acatenangensis.

66464,66468 . Q. pilicaulis.

67531. Q. crispipilis var. pannosifolia.

67536. Q. acatenangensis.

67537. Q. brachystachys.

$67538,67539,67543$. Q. acatenangensis.

67585. Q. pilicaulis.

67998. Q. skinneri.

68360,68374 . Q. pilarius.

68418. Q. skinneri.

68564. Q. crispifolia.

68686. Q. pilarius.

69127, 69560. Q. sapotaefolia.

69701. Q. conspersa.

69705. Q. peduncularis.

69716. Q. conspersa.

69721. Q. acatenangensis.

69747. Q. peduncularis.

69818. Q. sapotaefolia.

69824. Q. conspersa.

69895. Q. sapotaefolia.

69935, 70383. Q. crispifolia.

71001. Q. sapotaefolia.

71290. Q. pilarius.
Standley, P. C.-Continued.

75589, 76523, 76732. Q. peduncularis.

76739. Q. conspersa.

76747. Q. sapotaefolia.

76752. Q. conspersa.

76907. Q. tristis.

77241. Q. conspersa.

77324. Q. sapotaefolia.

77394. Q. conspersa.

79797, 84084. Q. brachystachys.

80624. Q. oocarpa.

80864. Q. peduncularis.

80865, 80872. Q. conspersa.

80895. Q. tristis.

80955. Q. peduncularis.

80982, 81072. Q. tristis.

81243. Q. peduncularis.

81244. Q. polymorpha.

81278. Q. crispipilis.

81437. Q. conspersa.

81545. Q. tristis.

81934, 81947. Q. peduncularis.

81976. Q. candicans.

82010. Q. peduncularis.

82076, 82104. Q. conspersa.

82108. Q. crispipilis.

82168. Q. conspersa.

82170. Q. candicans.

82183, 82213. Q. conspersa.

82253, 82256. Q. tristis.

82309. Q. peduncularis.

82315. Q. tristis.

82331, 82346. Q. conspersa.

82459, 82672. Q. crispipilis.

82765. Q. tristis.

83011. Q. conspersa.

83017, 83021. Q. candicans.

83044. Q. conspersa.

83117. Q. acatenangensis.

83133. Q. crispipilis.

83405. Q. acatenangensis.

83474. Q. conspersa.

$83561,83565,83567$. Q. acatenangensis.

83582. Q. pilicaulis.

83583, 83595, 84025, 84098.

Q. acatenangensis.

84099. Q. pilicaulis.

84356, 84358. Q. acatenangensis.

84360. Q. conspersa.

84396. Q. acatenangensis.

84398. Q. pilicaulis.

84631, 84747. Q. pilarius.

85213, 85217. Q. acatenangensis.

85219. Q. pilicaulis.

85225, 85284. Q. acatenangensis.

Standley, P. C., and Torres R., R.

47424. Q. oocarpa.

50921. Q. eugeniaefolia.

51147. Q. oocarpa.

51223. Q. gulielmi-treleasei.

51270. Q. oocarpa.

Standley, P. C., and Valerio, J.

43403. Q. corrugata.

43564, 43671. Q. costaricensis. 
Standley, P. C., ete.-Continued. $43752,43789,43972 . \quad$ Q. irazuensis.

43982. Q. copeyensis.

50546. Q. aáata.

50588. Q. eugeniaefolia.

50651. Q. aáata.

50707. Q. eugeniaefolia.

51382. Q. gulielmi-treleasei.

Stevenson, D.

52178, 52194. Q. aáata.

8939. Q. corrugata.

Stemermark, J. A.

29563. Q. segoviensis.

29573. Q. peduncularis.

29580. Q. hondurensis.

29697. Q. conspersa.

29724. Q. hondurensis.

30525. Q. oocarpa.

30625. Q. polymorpha.

30730 , p. p. Q. tristis.

30730 , p. p. Q. peduncularis.

30807. Q. oocarpa.

30808. Q. crispifolia.

30895, 30902. Q. tristis.

31476. Q. flagellifera.

31485. Q. oocarpa.

31551. Q. peduncularis.

31890. Q. tristis.

31947. Q. benthami.

32316. Q. peduncularis.

32379. Q. aáata.

32408. Q. acatenangensis.

32422. Q. tristis.

32423. Q. peduncularis var. sublanosa.

32425, 32430, 32543. Q. tristis.

32572 , 32594, 32596. Q. sapotae-

folia.

32601. Q. tristis.

32608. Q. peduncularis var. sublanosa.

32733. Q. sapotaefolia.

32740. Q. brachystachys.

32813. Q. crispifolia.

32937. Q. conspersa.

32939. Q. polymorpha.

32943. Q. peduncularis.

32966, 32973. Q. polymorpha.

32995. Q. tristis.

33000. Q. sapotaefolia.

33029. Q. acatenangensis.

33113. Q. candicans.

33159. Q. peduncularis.

33313. Q. skinneri.

33765. Q. corrugata.

33935. Q. skinneri.

33928. Q.tristis.

33963. Q. peduncularis.

33965. Q. skinneri.

34033. Q. peduncularis.

34036. Q. acatenangensis.

34230, 34368, 34369. Q. corrugata. 34968, 34970, 34982. Q. tristis.

35097. Q. skinneri.

35448. Q. pilarius.

35780, 35781. Q. acatenangensis.

Sterermark, J. A.-Continued.

36039. Q. flagellifera.

36161. Q. sapotaefolia.

36212 , 36274, 36376, 36389. Q. benthami.

36566,36615 . Q. conspersa.

36623. Q. tristis.

36914, 36916. Q. acatenangensis.

36918. Q. peduncularis.

37193. Q. skinneri.

37243. Q. corrugata.

37267. Q. benthami.

37570. Q. pilarius.

37990. Q. corrugata.

Stocker, C. L.

6. Q. purulhana.

STORK, H. E.

347. Q. costaricensis.

1042. Q. eugeniaefolia.

1129. Q. oocarpa.

1130. Q. eugeniaefolia.

1365. Q. aáata.

1500. Q. sapotaefolia.

1745. Q. seemanni.

2089. Q. costaricensis.

2420. Q. seemanni.

2591. Q. eugeniaefolia.

3052. Q. irazuensis.

3131. Q. seemanni.

Stork, H. E.- see also Rowlee, W. W. and STORк, H. E.

Terry, Mrs. M. E

1258, 1337. Q. seemanni.

Terry, Mrs. M. E.-see also Davidson, Mrs. M. E.

Thieme, C.

5440. Q. hondurensis.

5615. Q. oleoides.

Thomas, Bro.

766. Q. humboldtii.

Thomas, W. S.- see Dodge, C. W., and Thomas, W. S.

TONDUZ, A.

458, 461. Q. tristis.

739. Q. peduncularis.

7871 , p. p. Q. eugeniaefolia.

7871, p. p. Q. corrugata.

10788. Q. tonduzii.

11697, 11795. Q. seemanni.

11827. Q. borucasana.

12231. Q. seemanni.

17693. Q. oоcarpa.

Torres R., R.-see Standley, P. C., and Torres R., R.

Trelease, W.

$28,29,30$. Q. crispipilis var. pannosifolia.

31. Q. tristis.

$32,33,34,35,36,37,38,39,40,41$, 42. Q. pilicaulis.

$43,44,45,46,47$. Q. brachystachys. 48, 49, 50, 51. Q. peduncularis.

52. Q. acatenangensis.

53. Q. conspersa.

54. Q. acatenangensis.

55. Q. sapotaefolia.

$56,57,58 . \quad Q$. tristis. 
TÜRCKHEIM, H. von

3898. Q. conspersa.

3899. Q. skinneri.

Valerio, J. see Standley, P. C., and VALERIO, J.

VALERIO, M.

179. Q. eugeniaefolia.

Wagner, K. A. see Yuncker, T. G., Koepper, J. M., and Wagner, K. A.

WARSCEWICZ, J. VOO

26. Q. conspersa.

53. Q. costaricensis.

WAUCHOPE, R.

7. Q. conspersa.

Whitford, H. N., and Stadtmiller, L. R.

41, 55. Q. oleoides.

56. Q. hondurensis.

Wilson, C. L. see Hatch, W. R., and Wilson, C. L.

Woodson, R. E., Allen, P. H., and Seibert, R. J.

796. Q. seemanni.

868. Q. eugeniaefolia.

Woodson, R. E., and Schery, R. W.

286. Q. oocarpa.

318. Q. eugeniaefolia.

360. Q. panamandinaea.

383. Q. copeyensis.

Youse, H. R. - see Yuncker, T. G., Dawson, R. F., and Youse, H. R.

YUNCKER, T. G., DAWson, R. F., and Youse, H. R.

5961. Q. peduncularis var. sublanosa.

6116. Q. skinneri.

6136. Q. peduncularis var. sublanosa.

6180. Q. oocarpa.

6203. Q. sapotaefolia.

6204. Q. tenuiaristata.

6297. Q. pilarius.

6379. Q. sapotaefolia.

YunCKer, T. G., KoEPPER, J. M., and W AGNER, K. A.

8179. Q. oleoides.

8180. Q. peduncularis var. $s u b$. lanosa.

8181, 8185. Q. hondurensis. 


\section{LITERATURE CITED}

(1) De Candolle, Alphonso.

1864. Cupuliferae. Prodr. Syst. Univ. Veg. $16^{2}: 1-123$.

(2) Liebmann, F. M.

1869. Chenes de l'amerique tropicale. Pp. 1-29, illus.

(3) Muller, Cornelius H.

1942. The PROBlem of Genera and sUbGenera in the oAKs. Chron.

(4) Schwarz, O. Bot. 7: 12-14.

1936. ENTWURF ZU EINEN NATURLICHEN SYSTEM DER CUPULIFEREN UND Der gattung QUercus L. Notizbl. Bot. Gart. u. Mus. [BerlinDahlem] 13: 1-22.

(5)

1937. Fagaceae [IN M. BURret, Plantae duqueanae]. Notizbl. Bot. Gart. u. Mus. [Berlin-Dahlem] 13: 495-496.

(6) Trelease, W.

(7) Wenzig, TH.

1884. die eichenarten amerika's. Jahrb. K. Bot. Gart. u. Mus.

(8) Williams, Simon. [Berlin] 3: 175-219.

1939. SECONDARY VASCULAR TISSUES OF THE OAKS INDIGENOUS TO THE UNITED STATES - I. THE IMPORTANCE OF SECONDARY XYLEM IN DELIMITING ERYTHROBALANUS AND LEUCOBALANUS. TOrrey Bot. Club Bul. 66: 353-365, illus. 


\section{INDEX ${ }^{22}$}

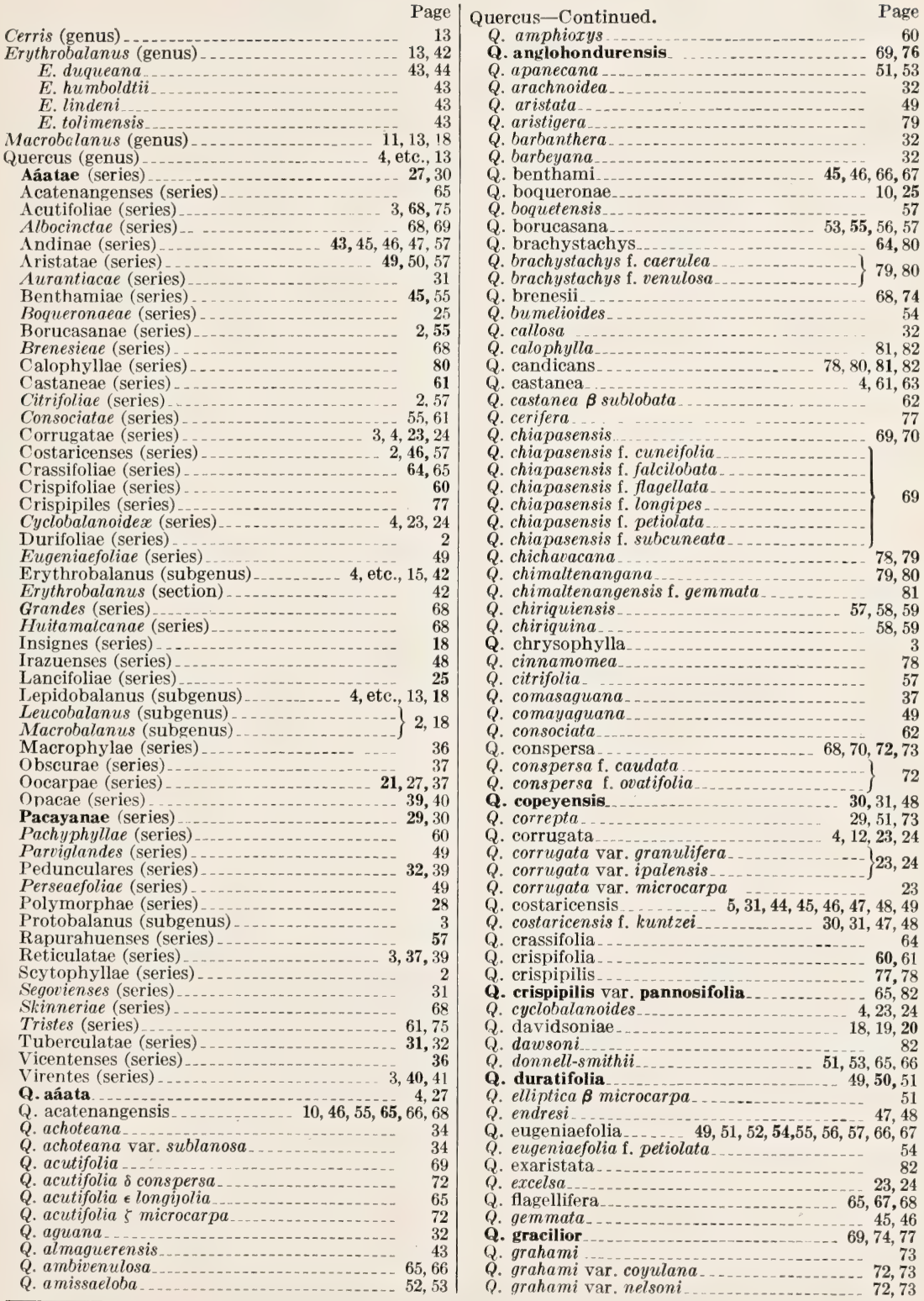

${ }^{22}$ New names and new combinations published for the first time in this publication appear in bold-faced ty pe, synon yms in italics, accepted names in roman; page numbers in bold-face indicate the place of principal treatment. 
Quercus-Continued.

Q. grandis..

$Q$. grandis var. tenuipes

Q. granulata

Q. guatimalensis

Q. guayabalana

Q. gulielmi-treleasei

Q. hemipteroides.

Q. hondurensis

Q. humboldtii.

Q. humboldtii var. lehmanniana

Q. incrassata

Q. insignis

Q. irazuensis

Q. lancifolia

Q. leophylla

Q. lindeni

Q. longifolia

Q. lutescens

Q. matagalpana

Q. microcarpa.

Q. monserratensis

Q. oleoides

Q. oleoides var. australis

Q. oleoides f. lutescens

Q. oocarpa

Q. opaca

Q. pacayana

Q. panamandinaea

Q. pannosifolia

Q. parviglans

Q. parviglans f. polycarpa

o. parviglans f. tejadana

Q. paxtalensis

Q. peduncularis.

O. peduncularis subsp. callosa

O. peduncularis subsp. hurteri

O. peduncularis subsp. pilicaulis

Q. peduncularis var. sublanosa

$Q$. perseaefolia var. achoteana

$Q$. pertessellata

Q. petiolaris

Q. phellos

Q. pilarius

Q. pilgeriana

Q. pilicaulis

$12,32,38,39$

Q. pilicaulis $\mathrm{f}$. concava

Q. pilicaulis f. elongato

Q. pilicaulis f. exserta

Q. pilicaulis f. hurteri

Q. pilicaulis f. macrodonta
Page | Quercus-Continued.

Page

$69,70,71 \quad$ Q. pilicaulis f. obovalis

69 Q. pittieri 55

55,56 Q. polymorpha _................ 28, 29, 73

Q. purulhana

Q. rapurahuensis $32,35,36$

Q. reevesii 23,24

Q. reticulata

Q. robur _.... 2, 13, 18

Q. rysophylla

Q. salicifolia var. seemanni____._._.... 57

Q. salvadorensis_._.

Q. sapotaefolia_ $29,49,50,51,52,53,54,65,66,73,82$

Q. scherzeri 62

$\begin{array}{ll}\text { Q. schippii } & 62 \\ & \end{array}$

Q. sebifera

Q. sebifera f. comitanensis

Q. seemanni__.___ $46,54,57,58,59,66,67$

Q. segoviensis

Q. seibertii $\ldots$

Q. siguatepequeana
Q. skinneri $68,69,70,71,73$

Q. skutchii _.. 78,79

Q. skutchiif. oblanceolata
Q. skutchiif. sublobata

Q. skutchii $\mathrm{f}$. undulata

Q. subcrispata

Q. tenuiaristata .......... 68,75

Q. tolimensis_._. 43,44

Q.tomentosa $\delta$ abbreviata
Q. tomentosa $\beta$ bullata

Q. tonduzii .

Q. trichodonta $\quad 69,70$

Q. tristis _

Q. tristis $\mathrm{f}$ miacoensis

Q. tristis $\mathrm{f}$. niederleini $\mathrm{t}$.

62

Q. tristis f. vulcani_ata

$\begin{array}{ll}\text { Q. tuberculata } & 31 \\ \text { Q. } & \end{array}$

Q. turbinata $\ldots$

Q. turbinella ........

Q.varians 28

Q. vicentensis _... 36,37

Q. virginiana

Q. warscewiczii

Q. wesmaeli_................ $52,53,55$

Q. xalapensis var. longifolia_.......... 65

Q. yoroensis_............ $\} \quad 49$

Q. yousei

Q. yunckeri 

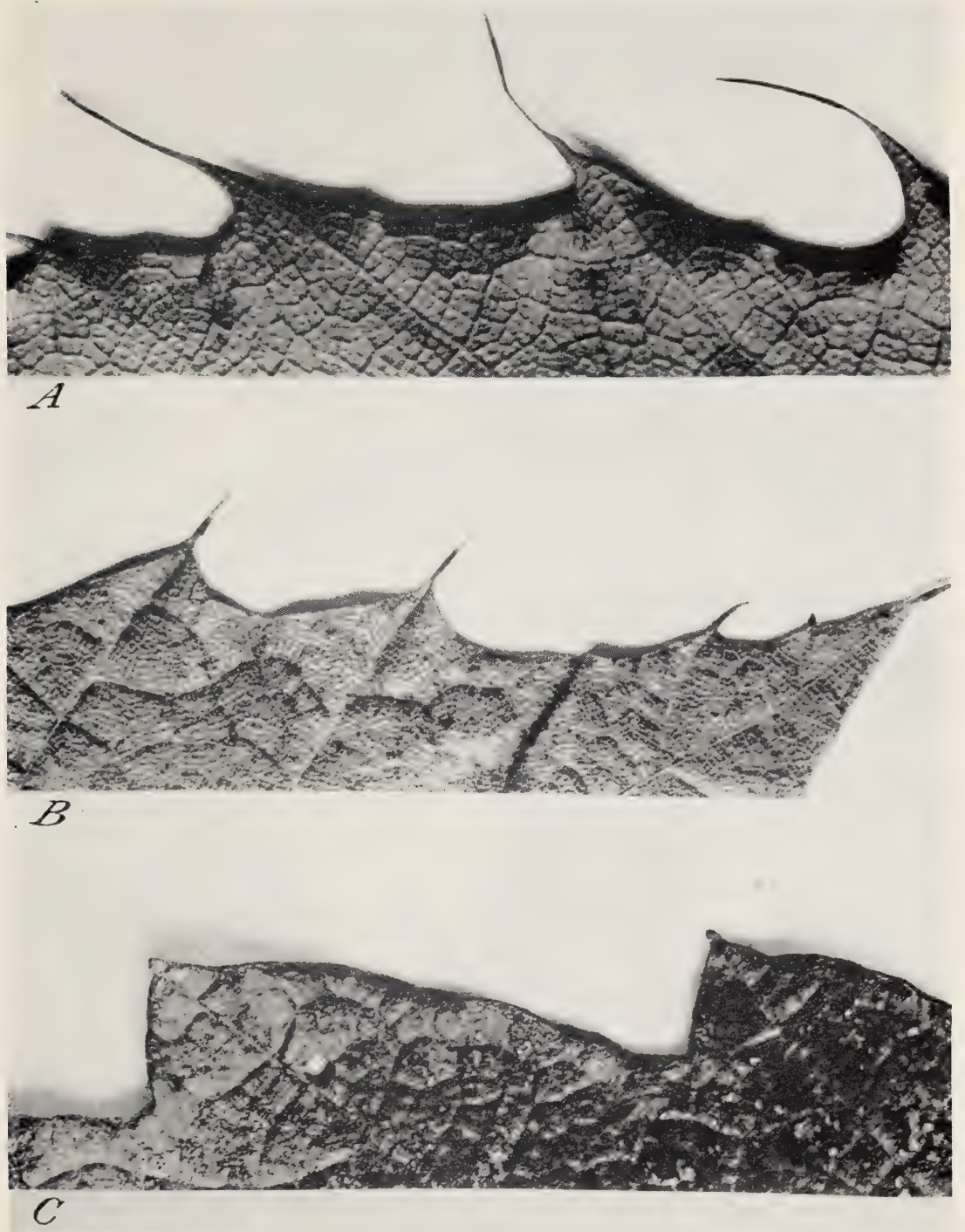

Leaf margins of Quercus: A, Extreme aristate-tipped teeth, Q. monserratensis C. H. Mull.; $B$, moderate aristate-tipped teeth, $Q$. candicans Nee; $C$, mucronatetipped teeth, Q. peduncularis Nee (all $\times 3$ ). 

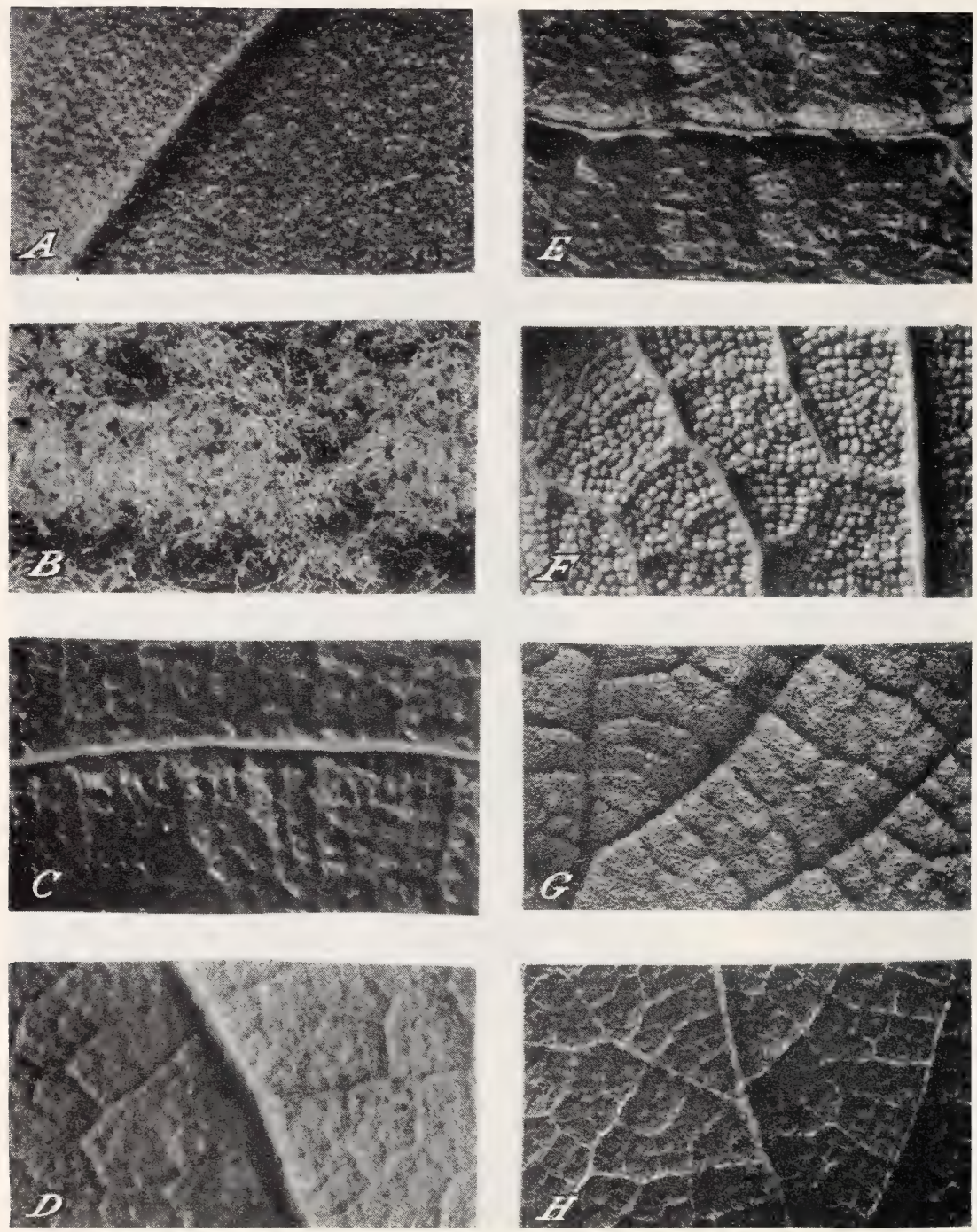

Leaf surfaces of Quercus: $A$, Short tomentum - lower surface of $Q$. oleoides Schlecht. and Cham.; $B$, loose tomentum-lower surface of $Q$. humboldtii Bonpl.; $C$, raised veins-upper surface of $Q$. benthami A. DC.; $D$, raised veins-lower surface of $Q$. benthami A. DC.; $E$, impressed veinlets-upper surface of $Q$. tristis Liebm.; $F$, granular bullate surface-lower surface of $Q$.tristis Liebm. (all $\times 10)$; $G$, impressed veins-upper surface of $Q$. pilicaulis Trel. $(\times 3) ; H$, prominent reticulum-lower surface of $Q$. pilicaulis Trel. $(\times 3)$. 


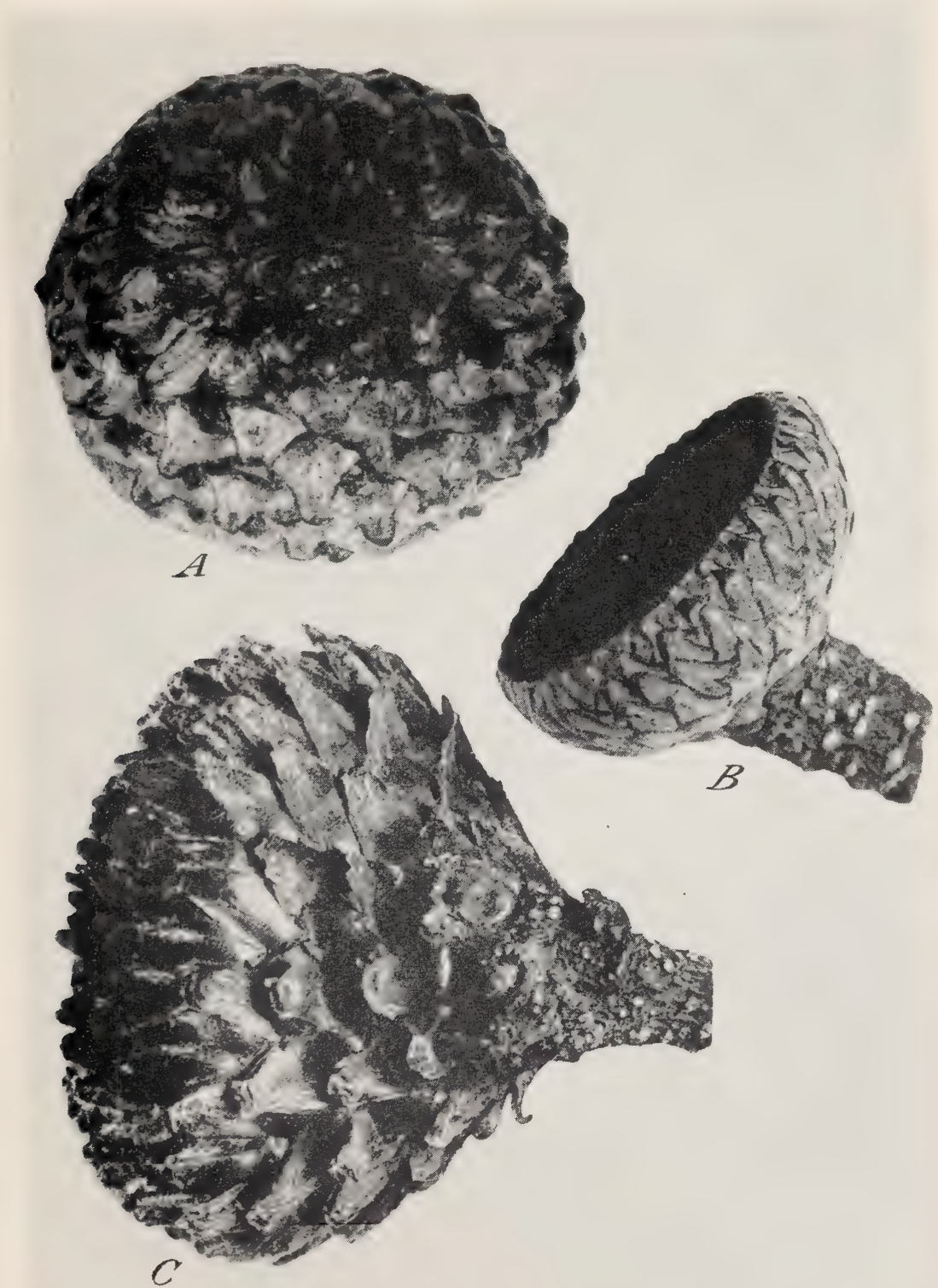

C'ups of Erythrobalanus: A, Thickened scales, Q. monserrateneis C. H. Mull.; B, thin, closely appressed scales, $Q$. candicans Nee; $C$, thin, loosely appressed scales, Q. costaricensis Liebm. (all $\times 3)$. 

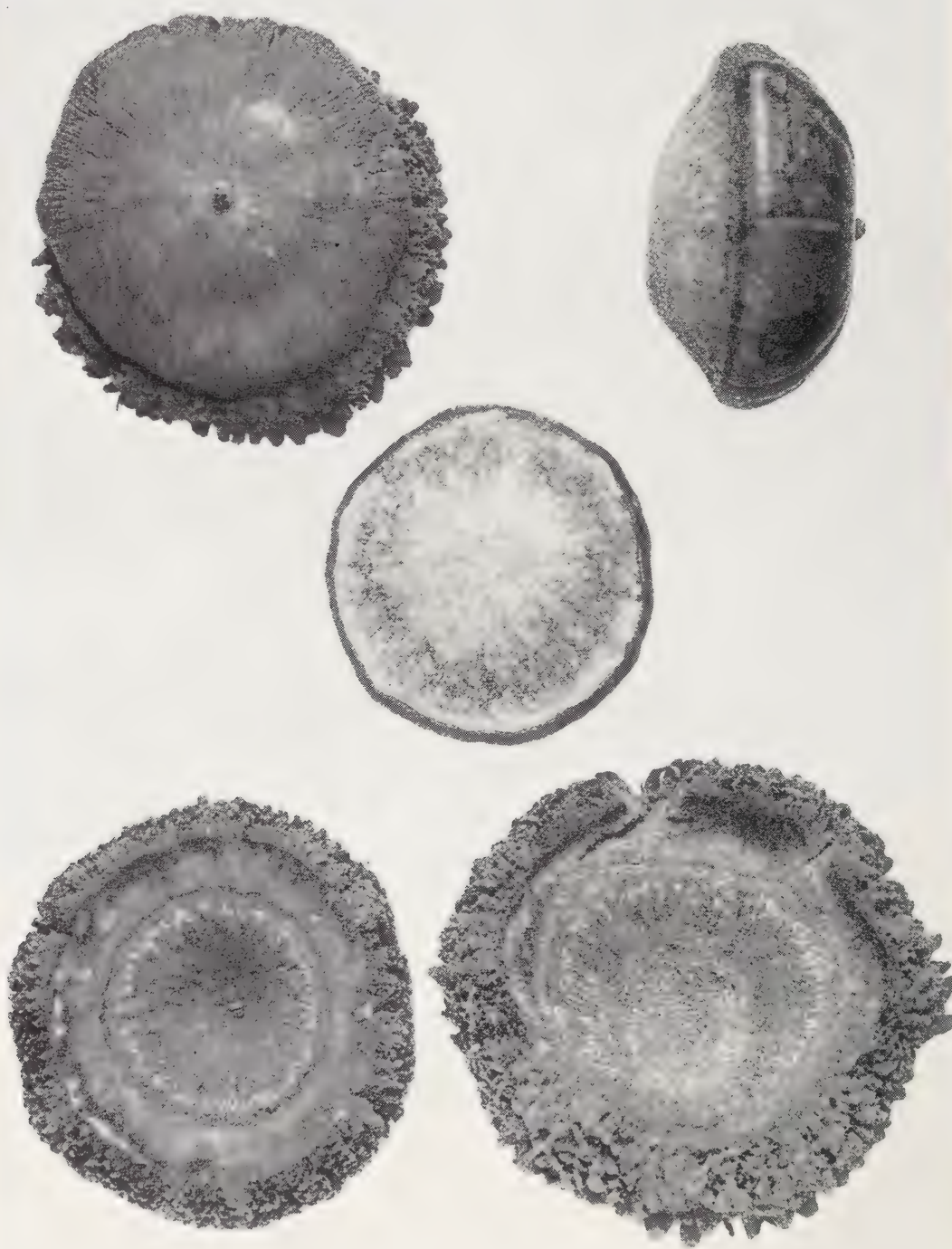

Quercus insignis Liebm. Representative fruit from Veracruz, Mexico (Purpus 7386-USNA seed collection). 


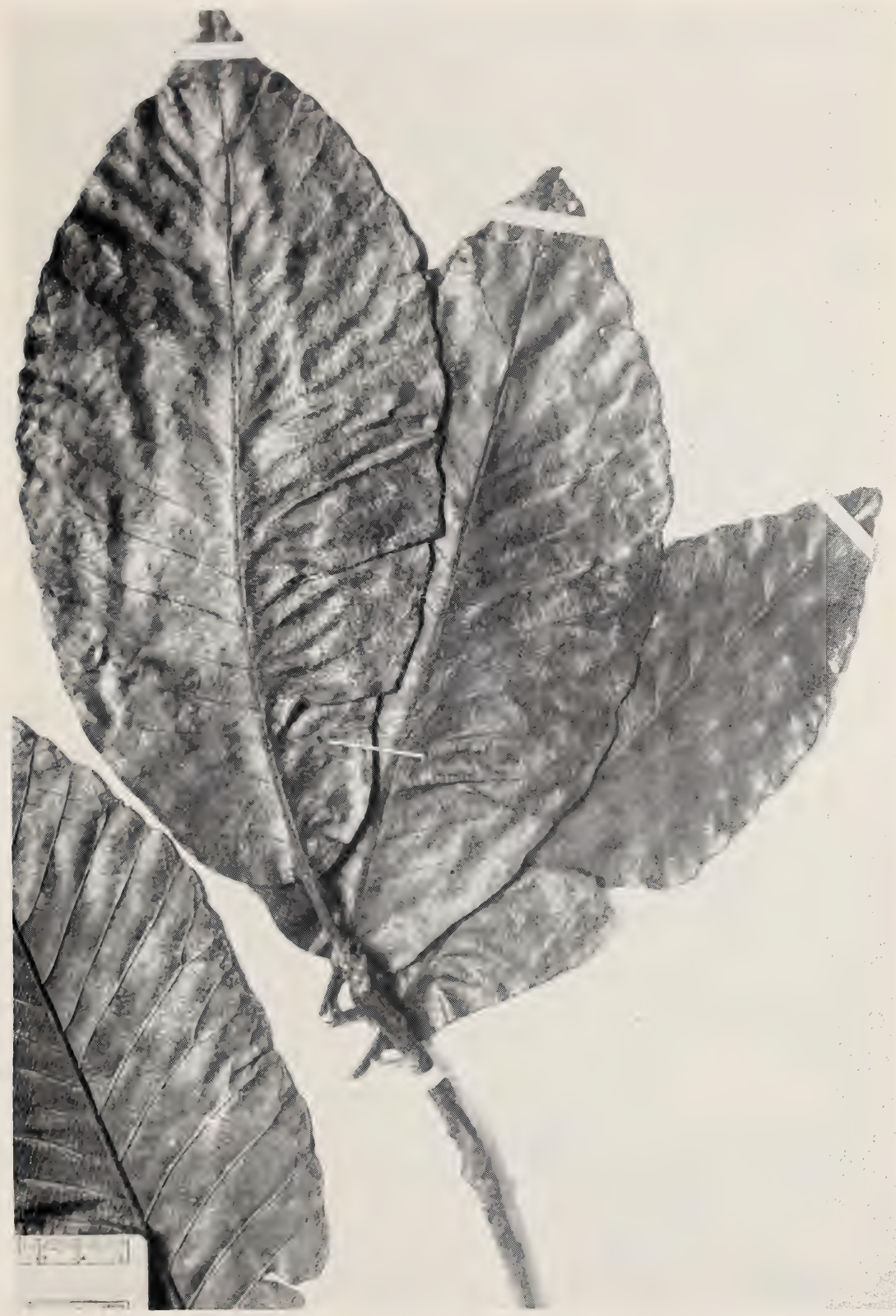

Quercus insignis liebm. 'The type of (2. schippli Standl. from British Honduras on the Guatemala boundary ('schipp 1:35-F). 
Miscellaneous Publication 477, U. S. Dept, of Agriculture

PLATE 6

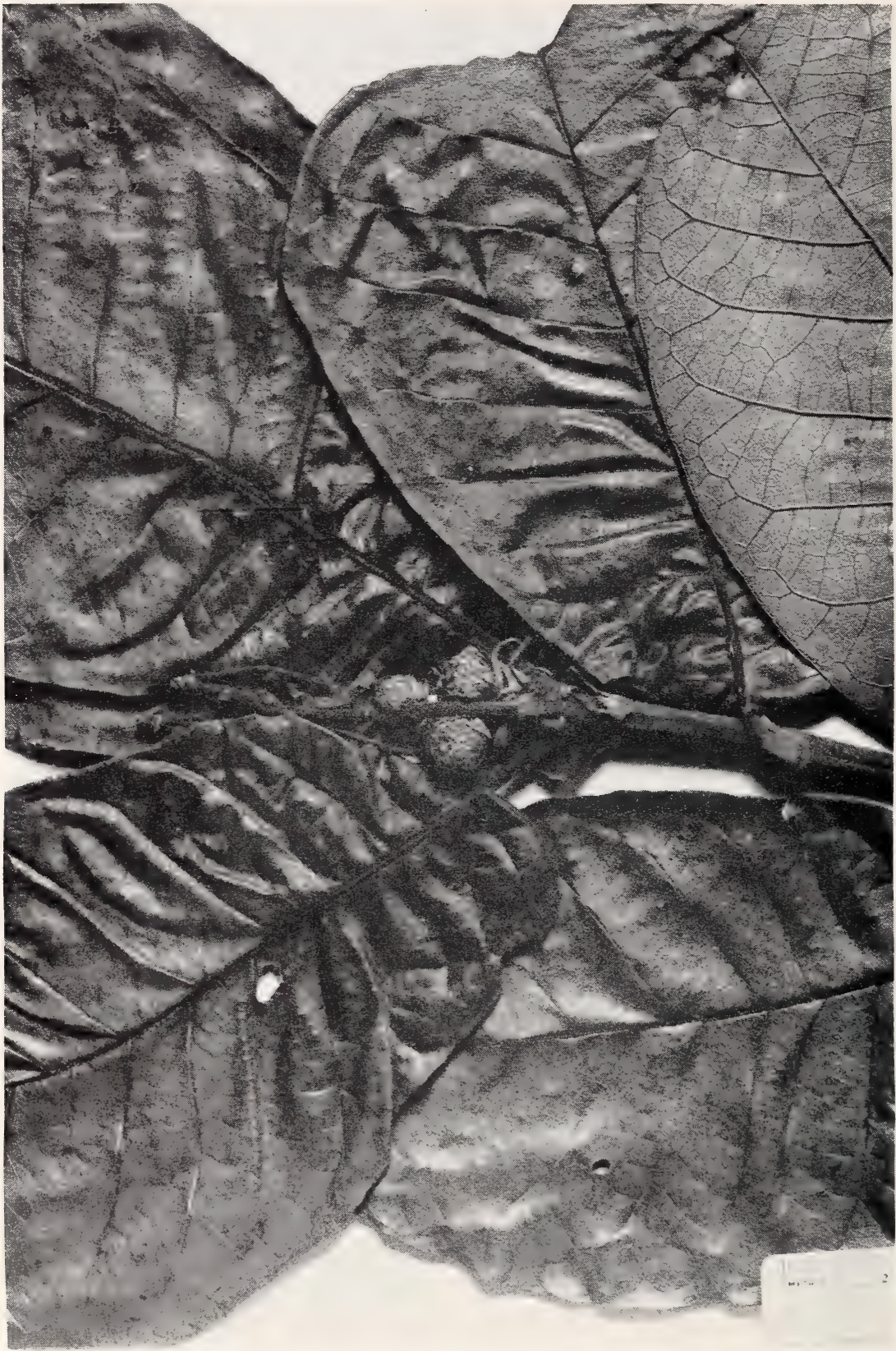

Quercus seibertii sp. nov. Type from Panama (Seibert 225-AA). 


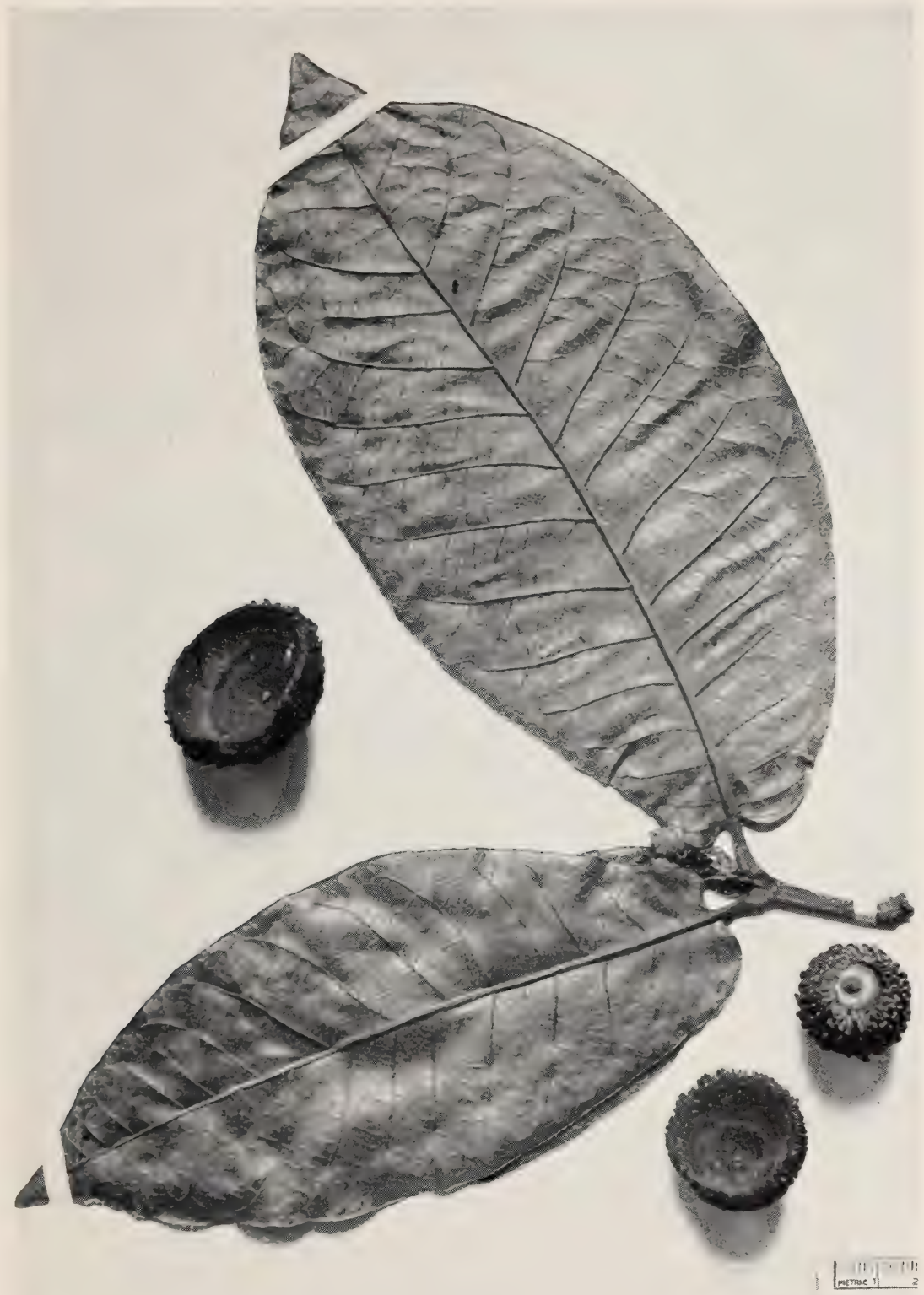

Quercus seibertin sp. nov. Isotype from Panama (Seibert 225-MBG). 
Miscellaneous Publication 477, U. S. Dept. of Agriculture

PLATE 8

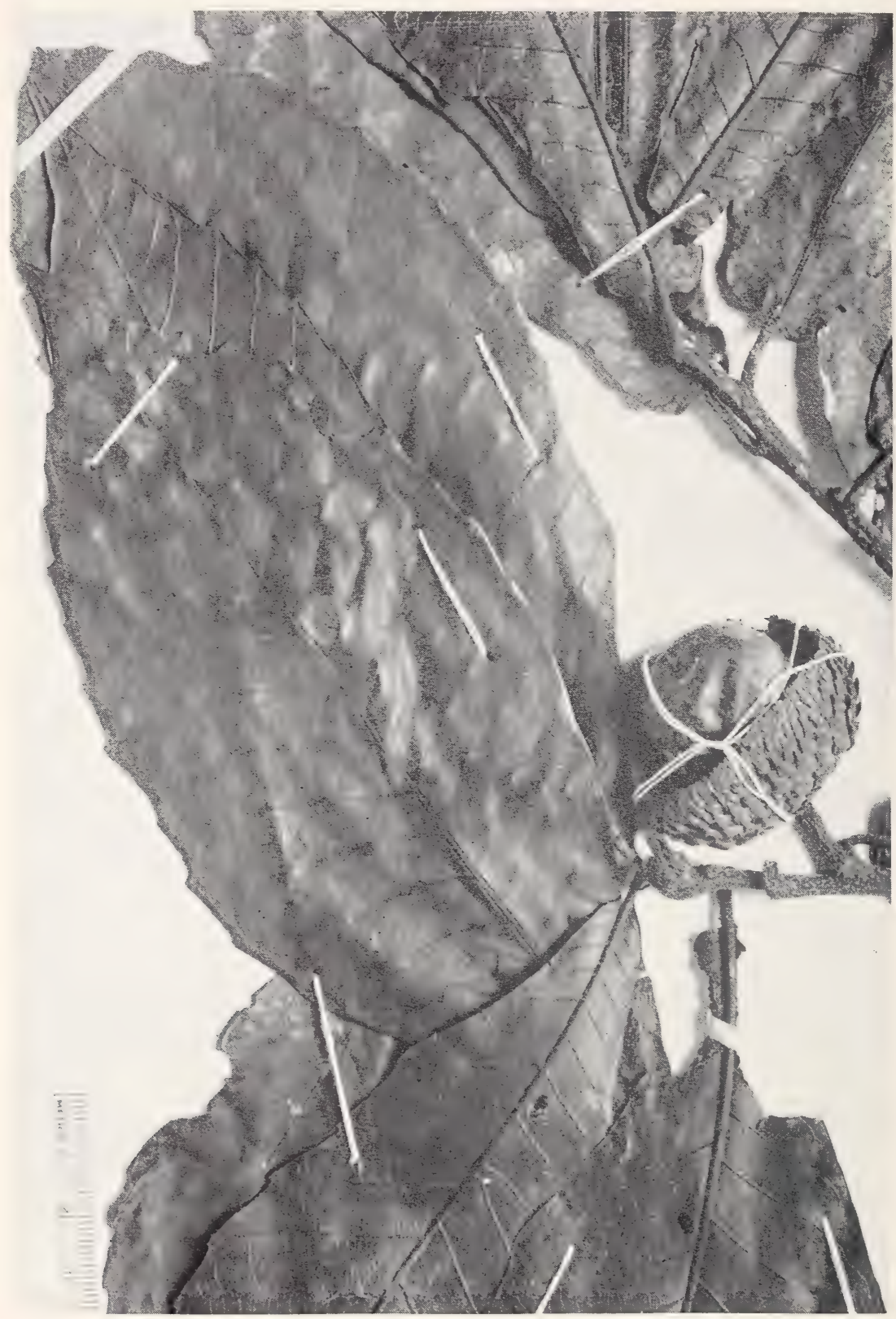

Quercus davidsoniae Standl. Type from Panama (Davidson 86'-F). 


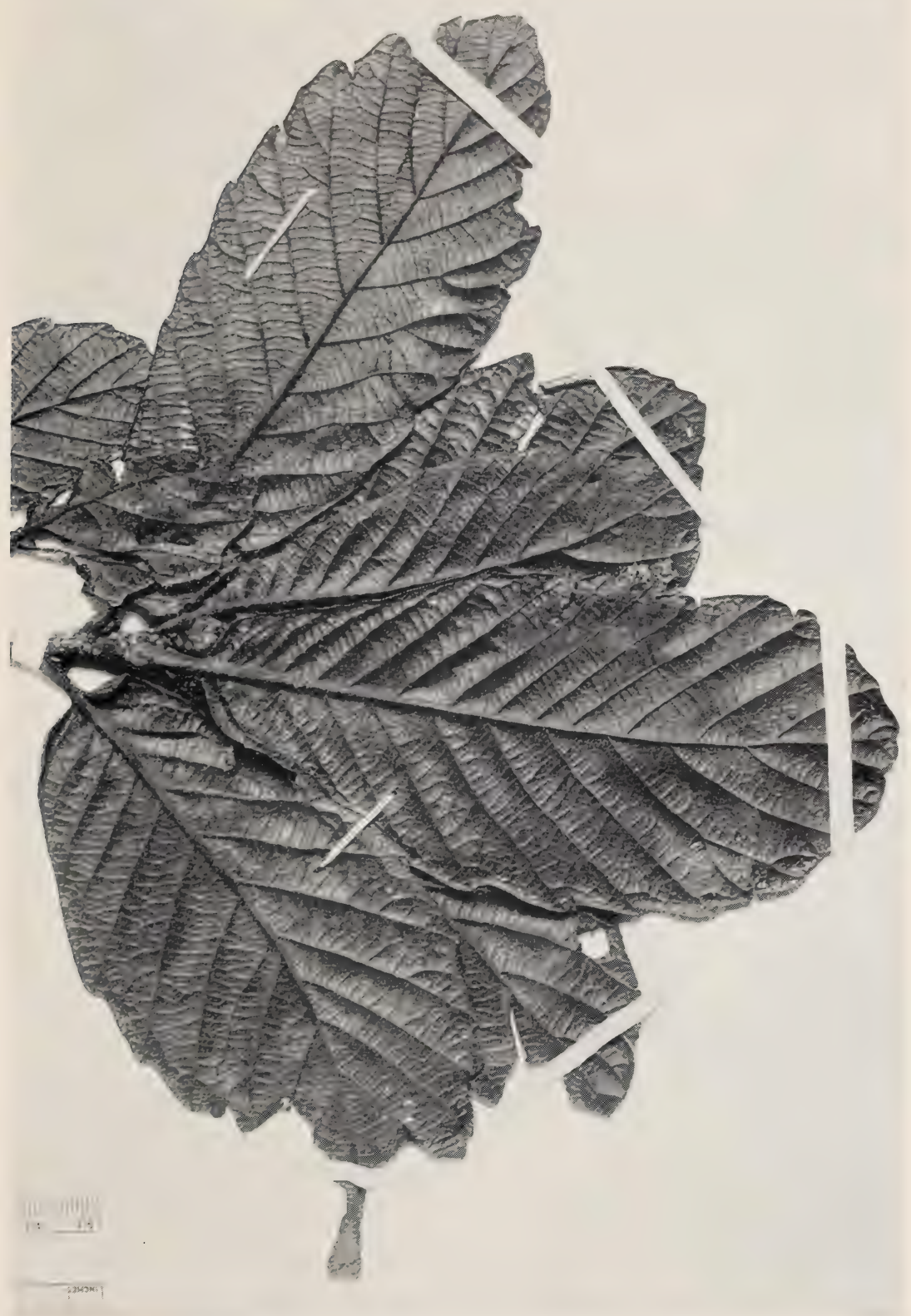

Quercus davidsoniae Standl. A variant from Costa Rica (Smith 141-F). 


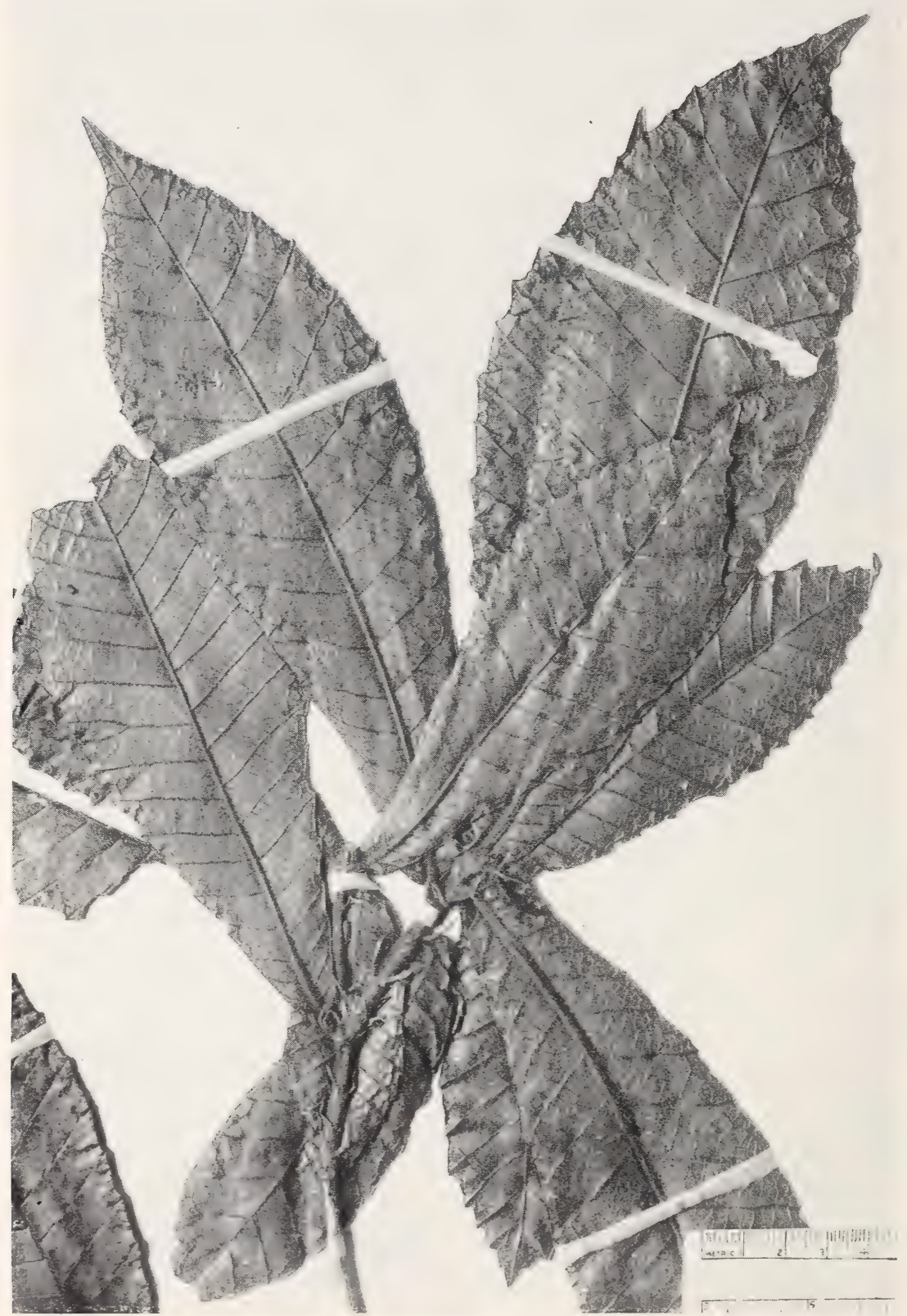

Quercus oocarpa Liebm. A representative specinien from Guatemala (Cook 220 - US). 


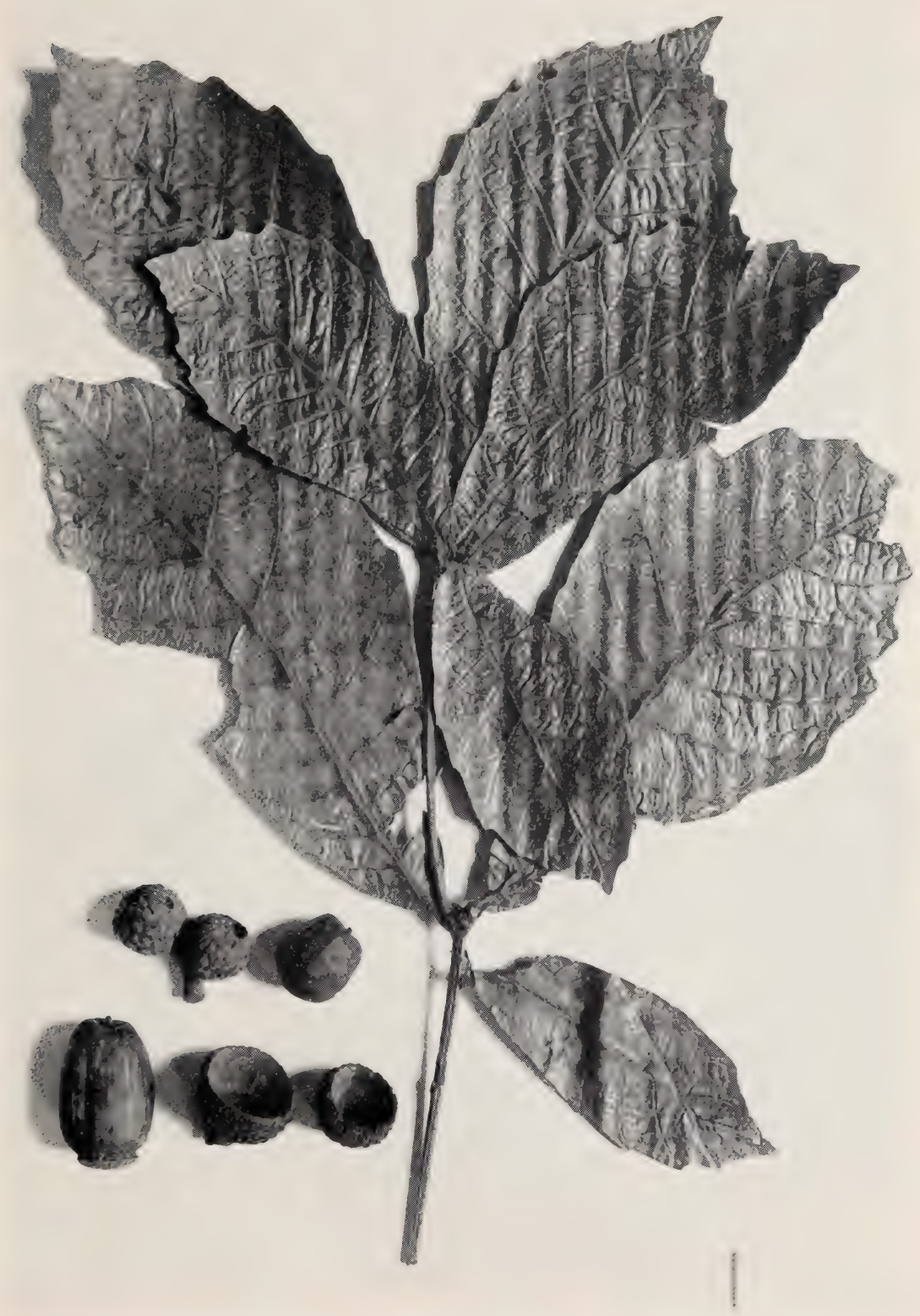

Quercus oocarpa Liebm. A variant from Panama (Allen 303-USNA). 
104 MISC. PUBLICATION 477 , U. S. DEPT. OF AGRICULTURE

Miscellaneous Publication 477, U. S. Dept. of Agriculture

Plate 12

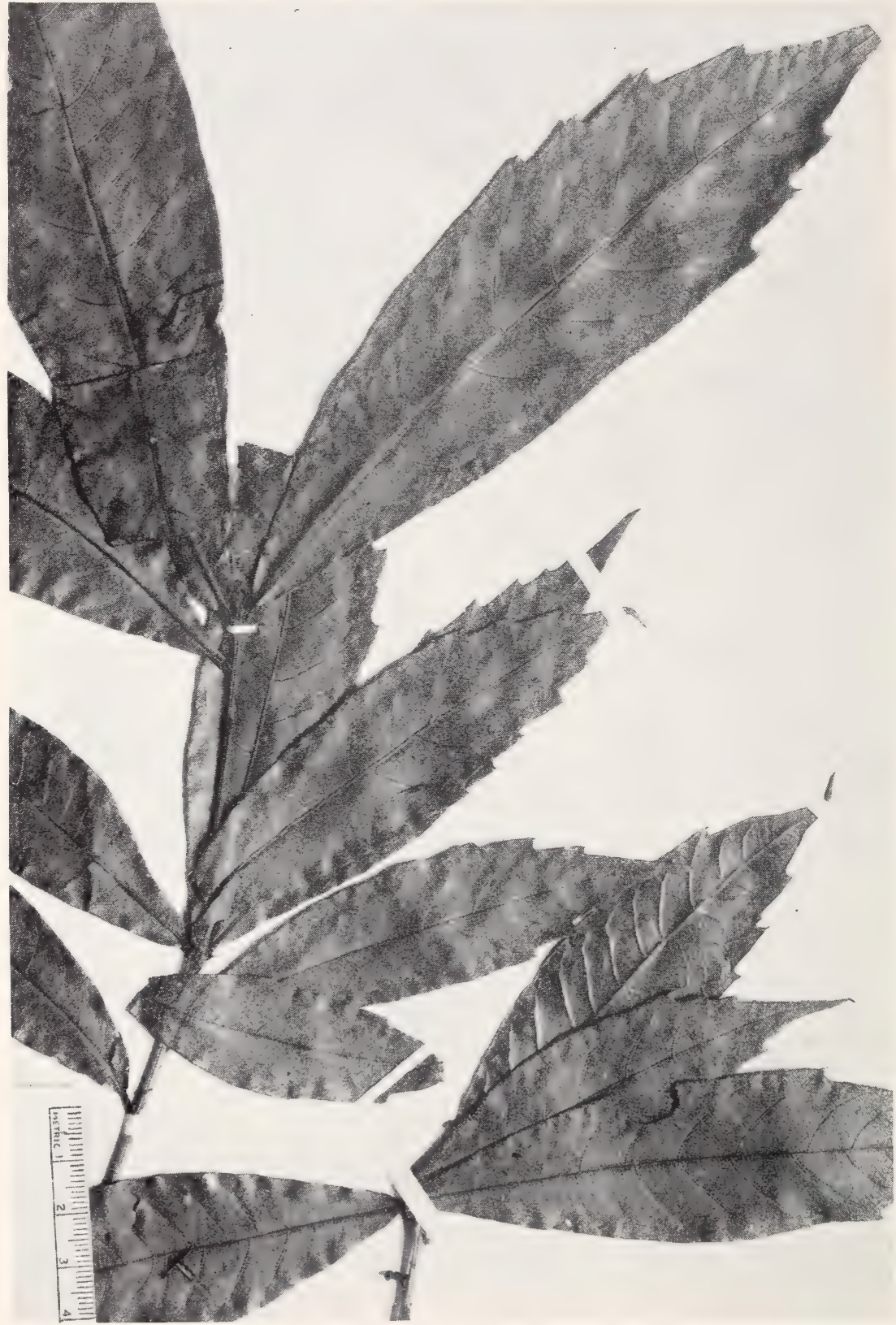

Quercus pilarius Trel. A representative specimen from Guatemala (Standley 71290-F). 


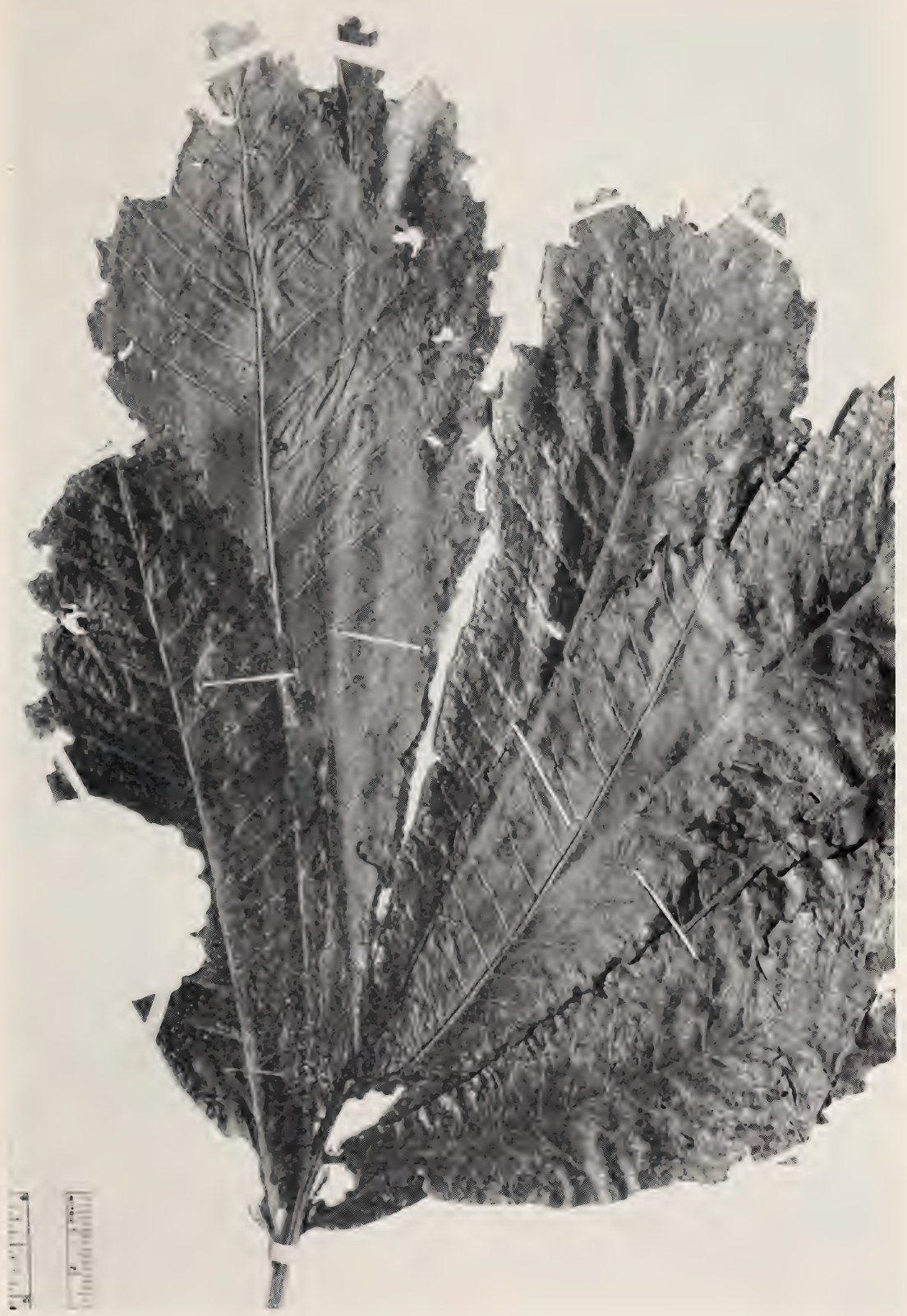

Quercus pilarius Trel. A shade variant from Guatemala (Steyermark 35448-F). 
Miscellaneous Publication 477, U. S. Dept. of Agriculture

PLATE 14

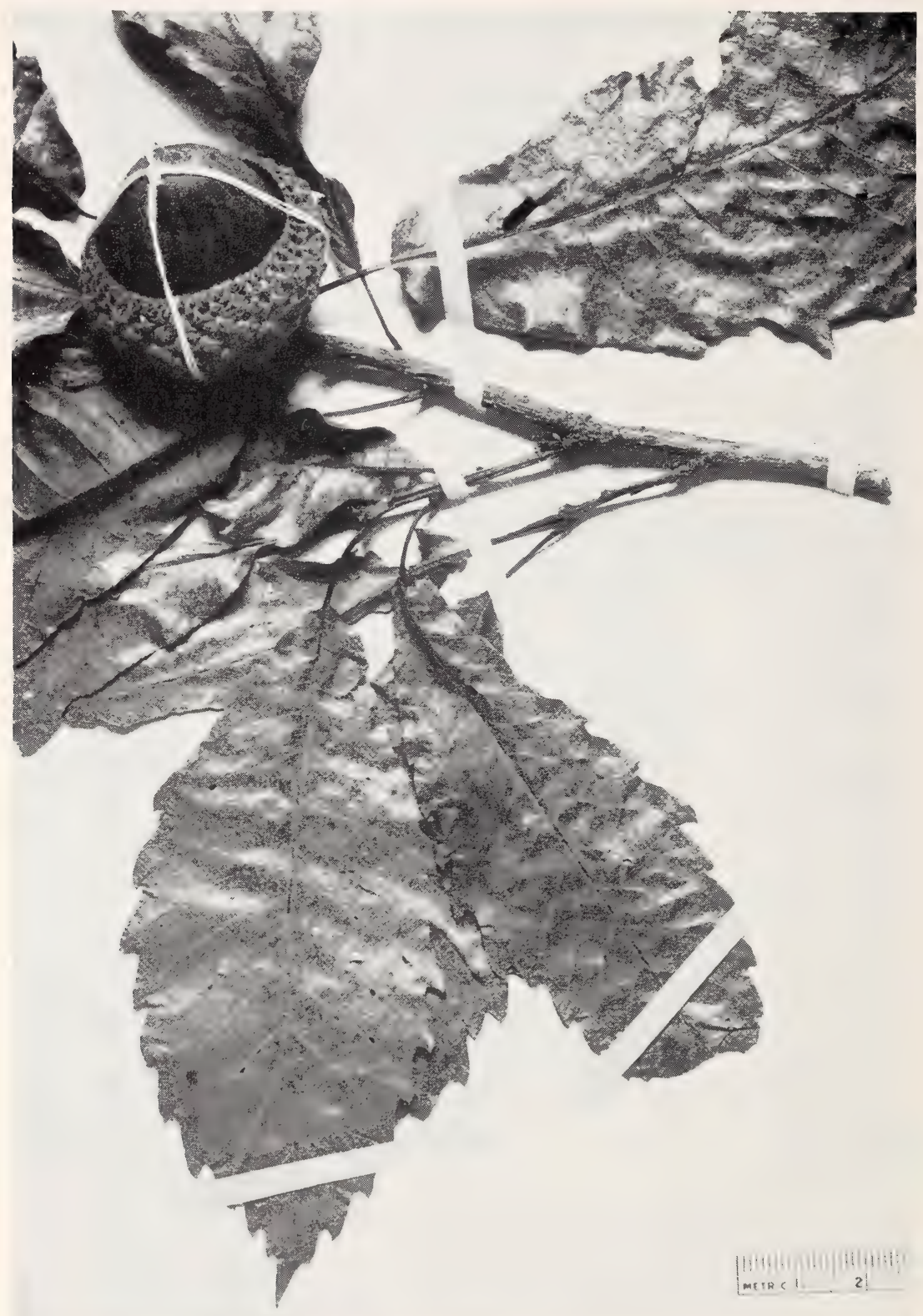

Quercus corrugata Hook. A representative specimen from Guatemala (Muenscher $12453-\mathrm{F})$. 


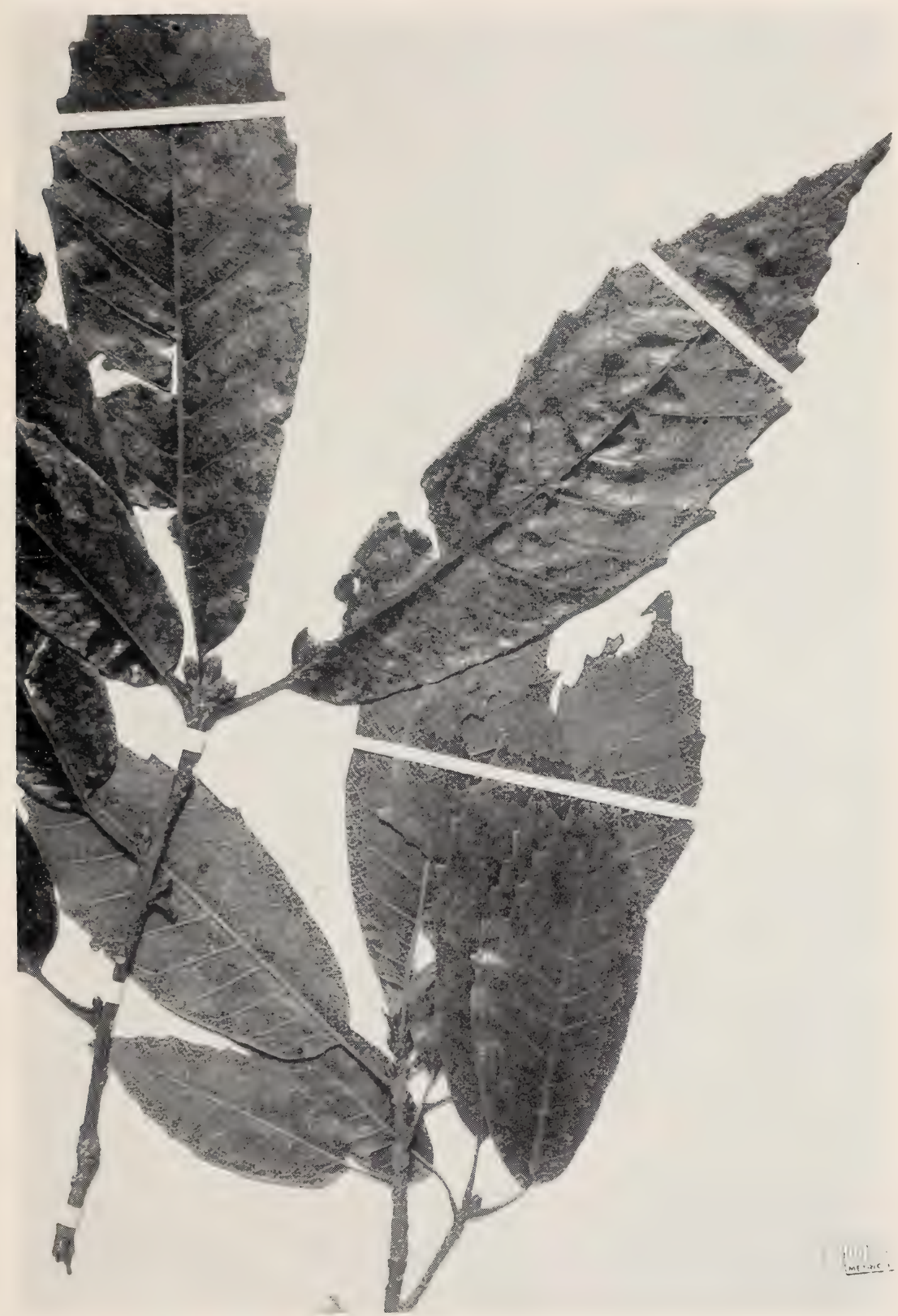

Quercus corrugata Hook. A characteristic specimen from Costa Rica (Standley and Valerio 43403-US). 
108 Misc. PUblicATION 477, U. S. DEPT. OF AGRICULTURE

Miscellaneous Publication 477. U. S. Dept. of Agriculture

PLATE 16

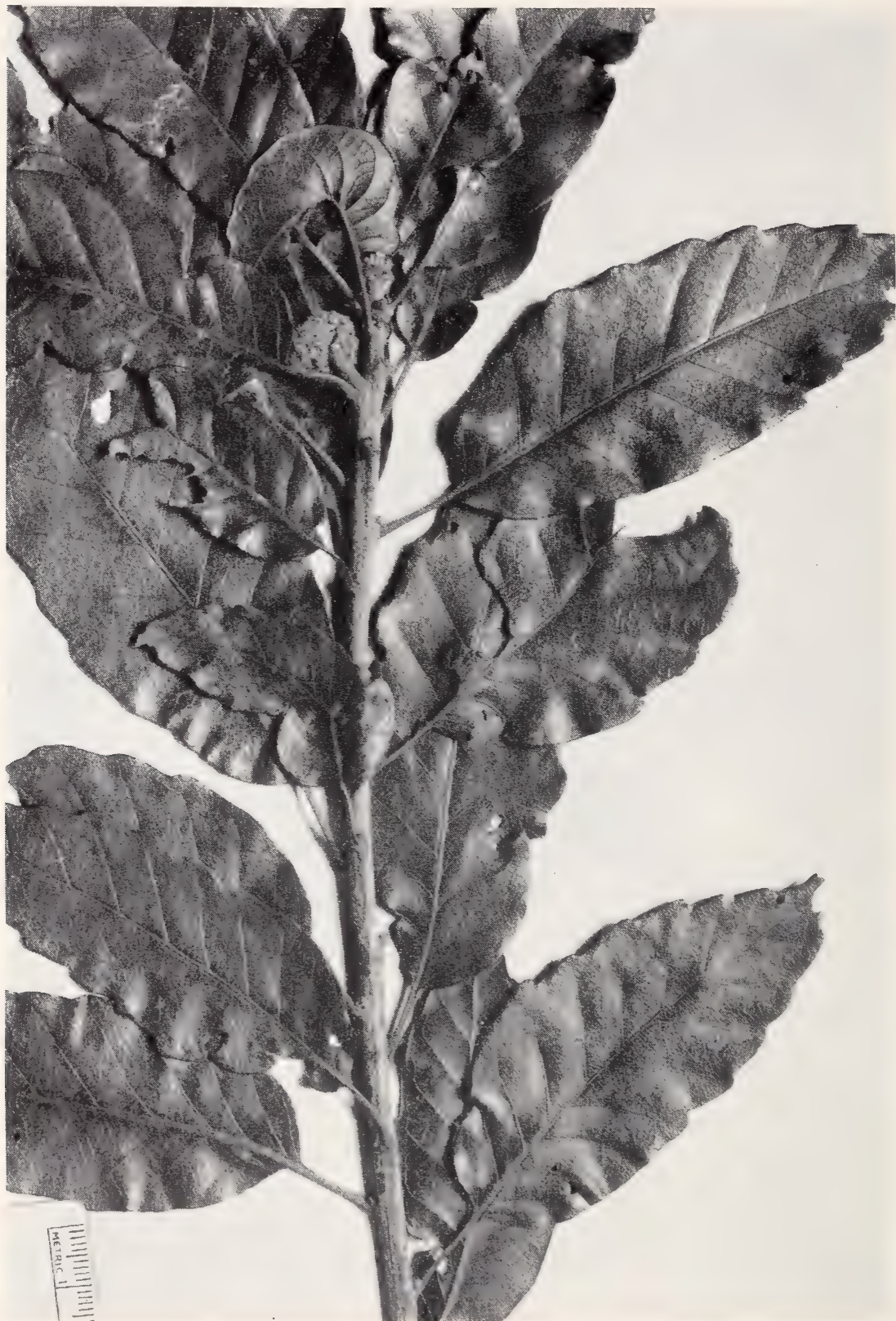

Quercus corrugata Hook. Isotype of Q. pilgeriana Seemen from Costa Rica (Pittier 2197-US). 


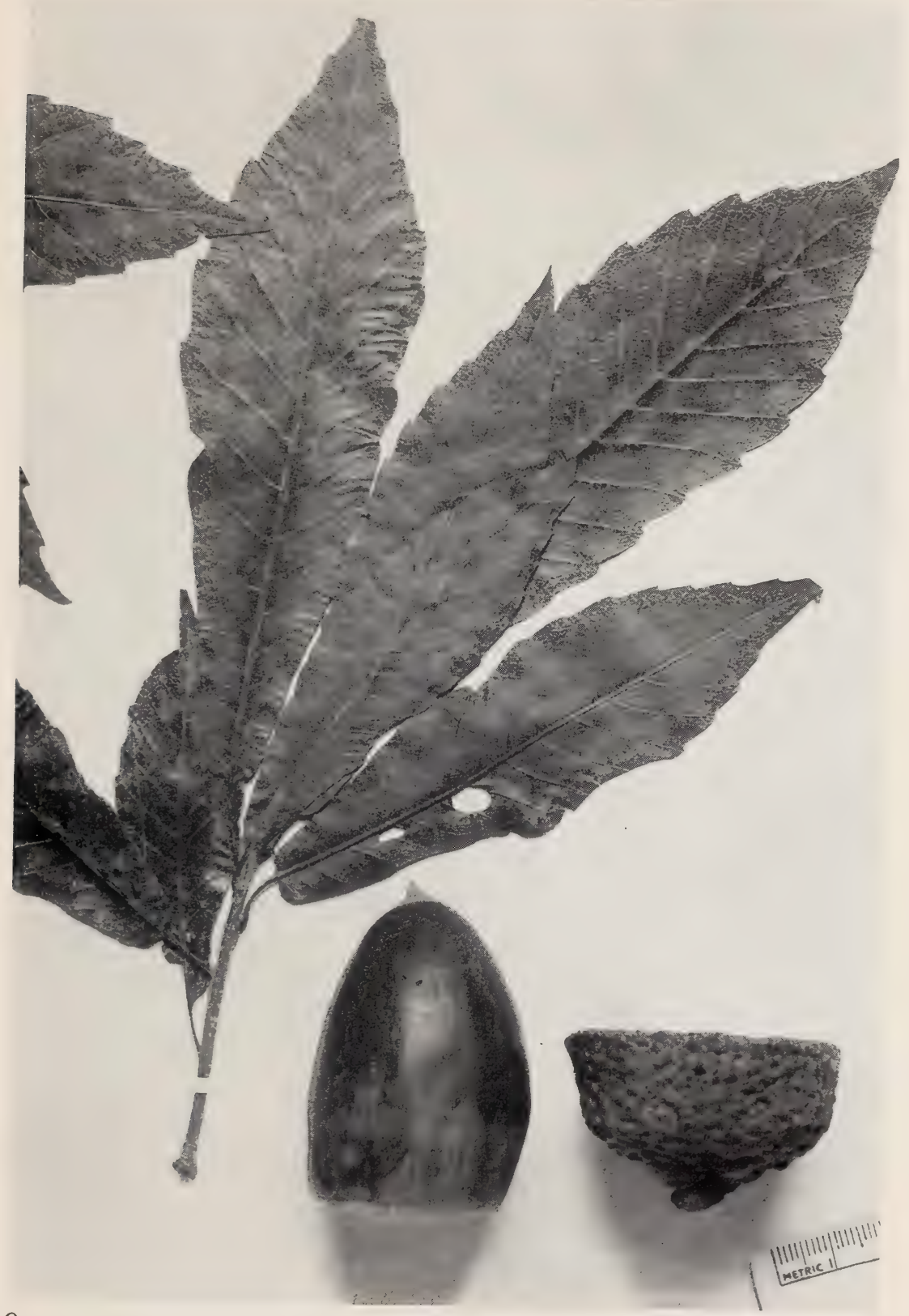

Quercus corrugata Hook. Type of Q. reevesii Trel. from Guatemala (Reeves F' ebruary 1918-I11). 


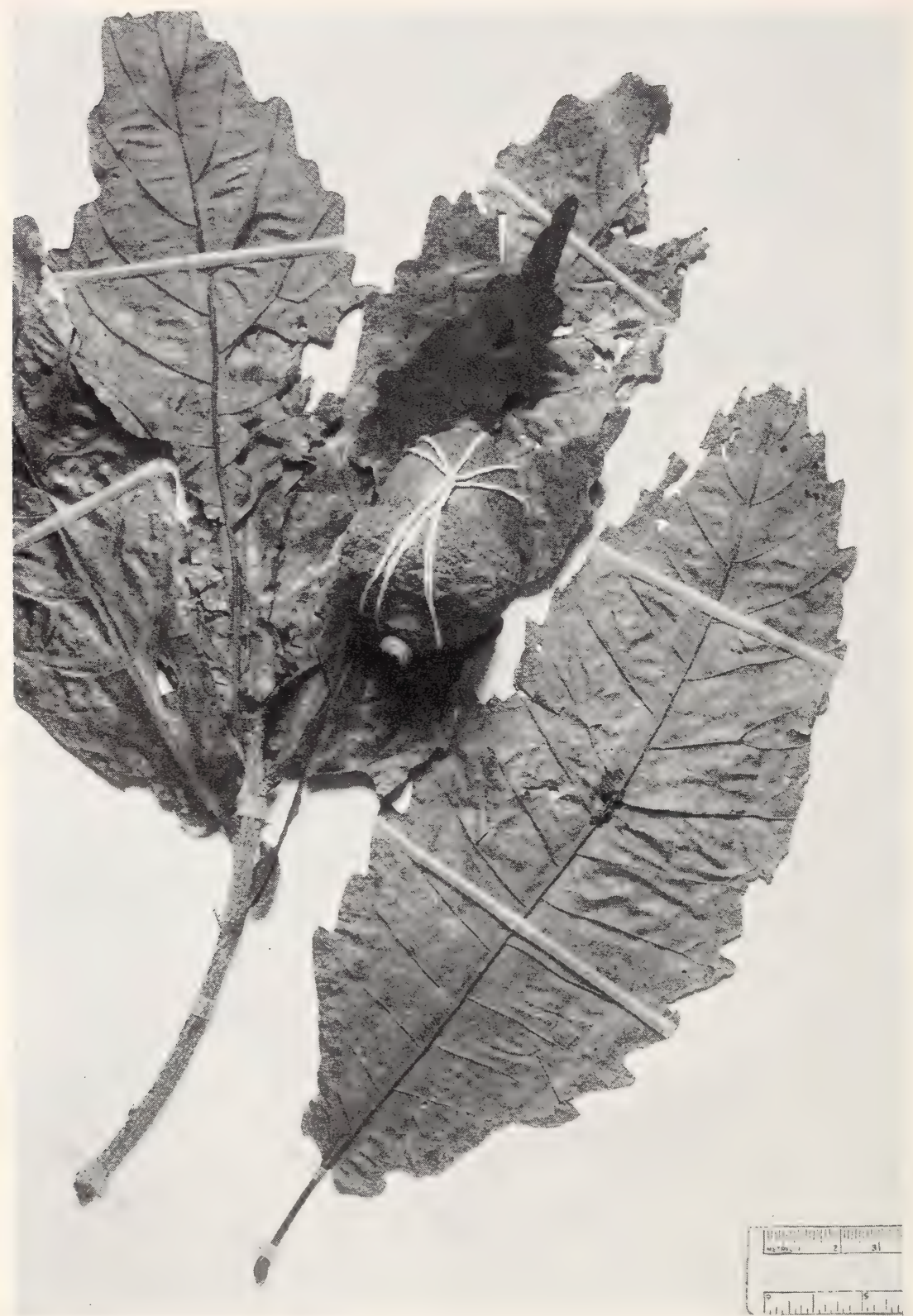

Quercus corrugata Hook. A shade variant and the type of $Q$. cyclobalanoides Trel. from Chiapas, Mexico (Purpus 6998-US). 


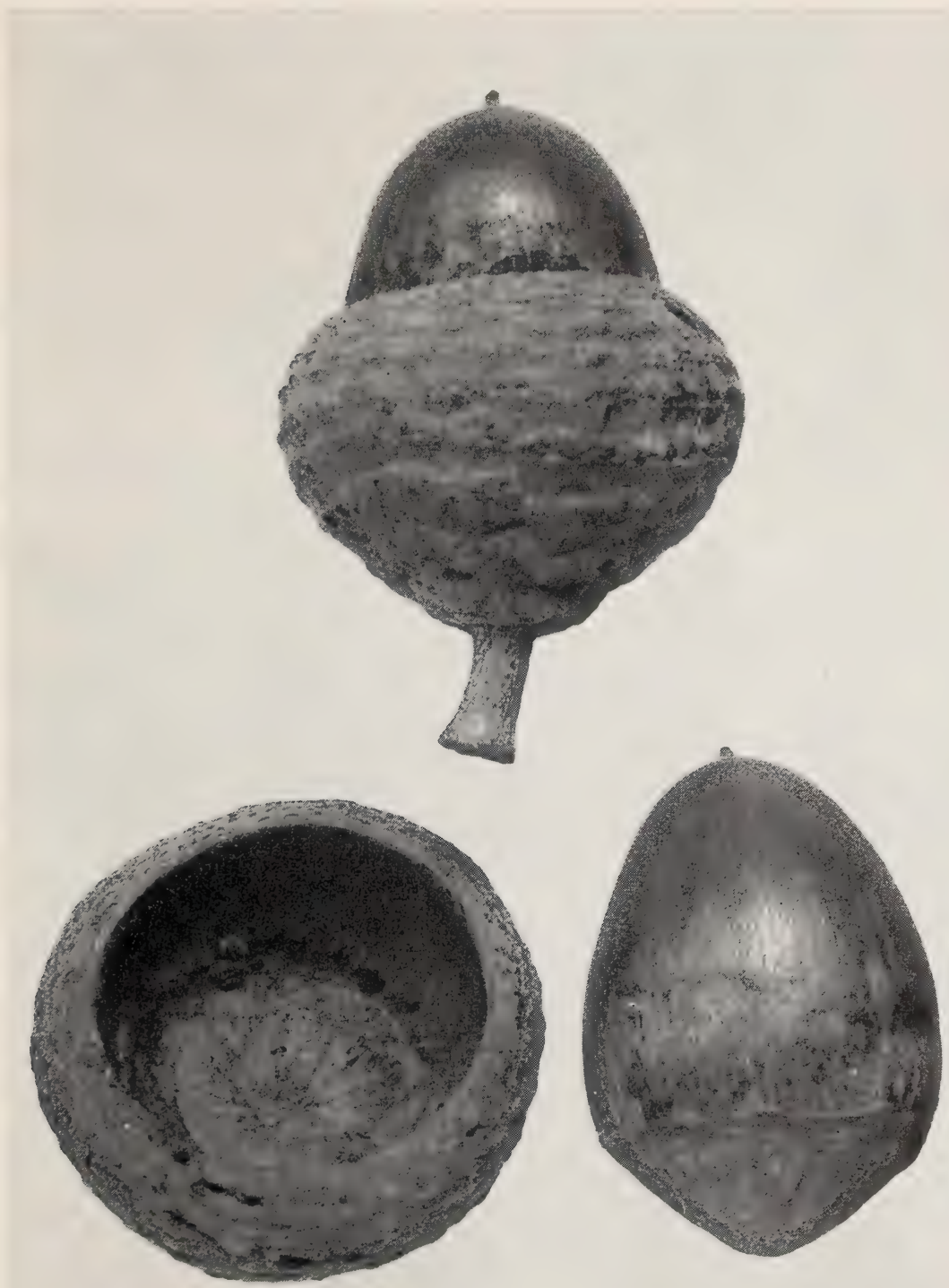

Quercus corrugata Hook. Isotype of Q. cyclobalanoides Trel. (Purpus 6998-USNA seed collection). 
Miscellaneous Publication 477, U. S. Dept. of Agriculture

Plate 20

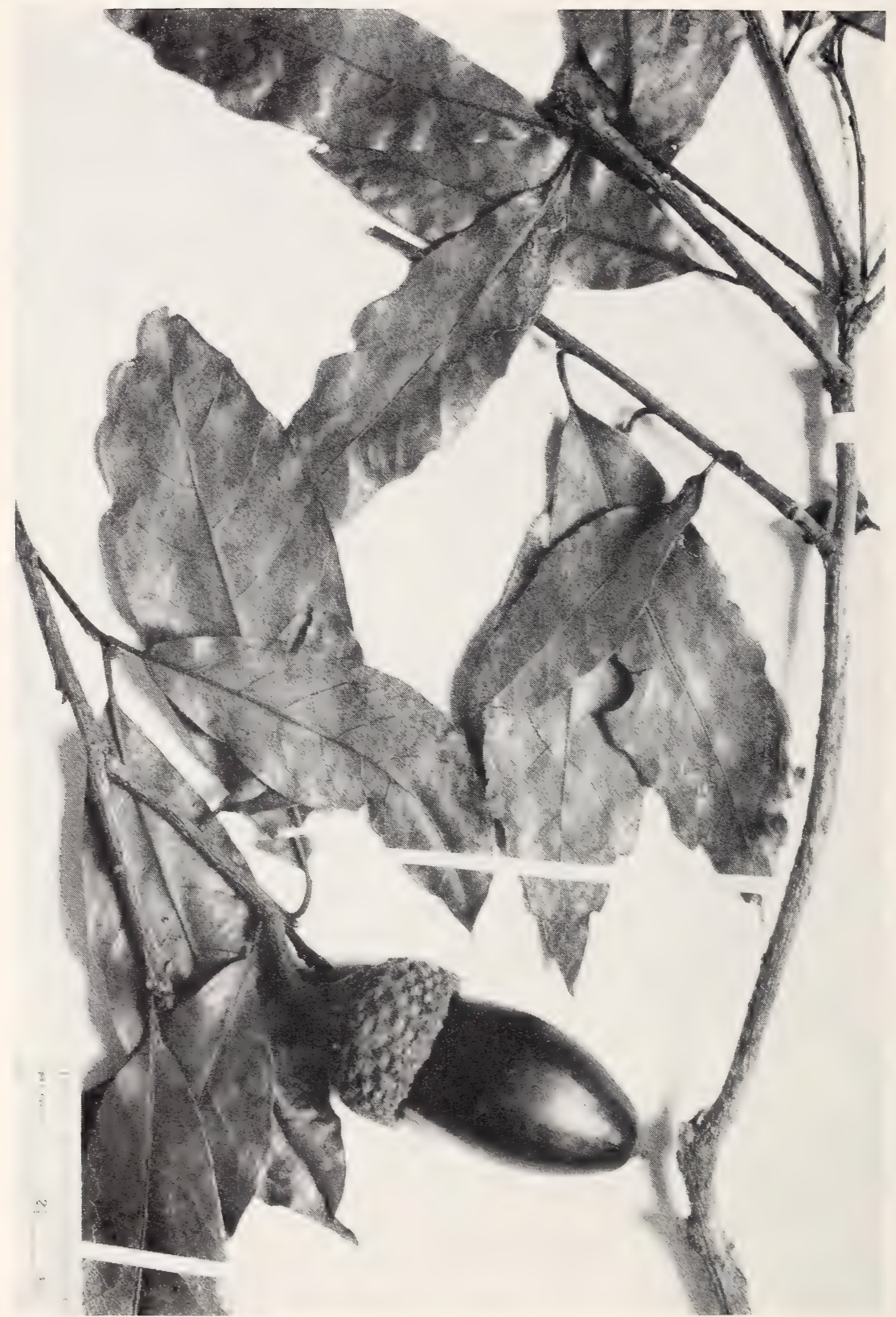

Quercus boqueronae Trel. A representative specimen from Chiapas, Mexico (Matuda 1824-AA). 


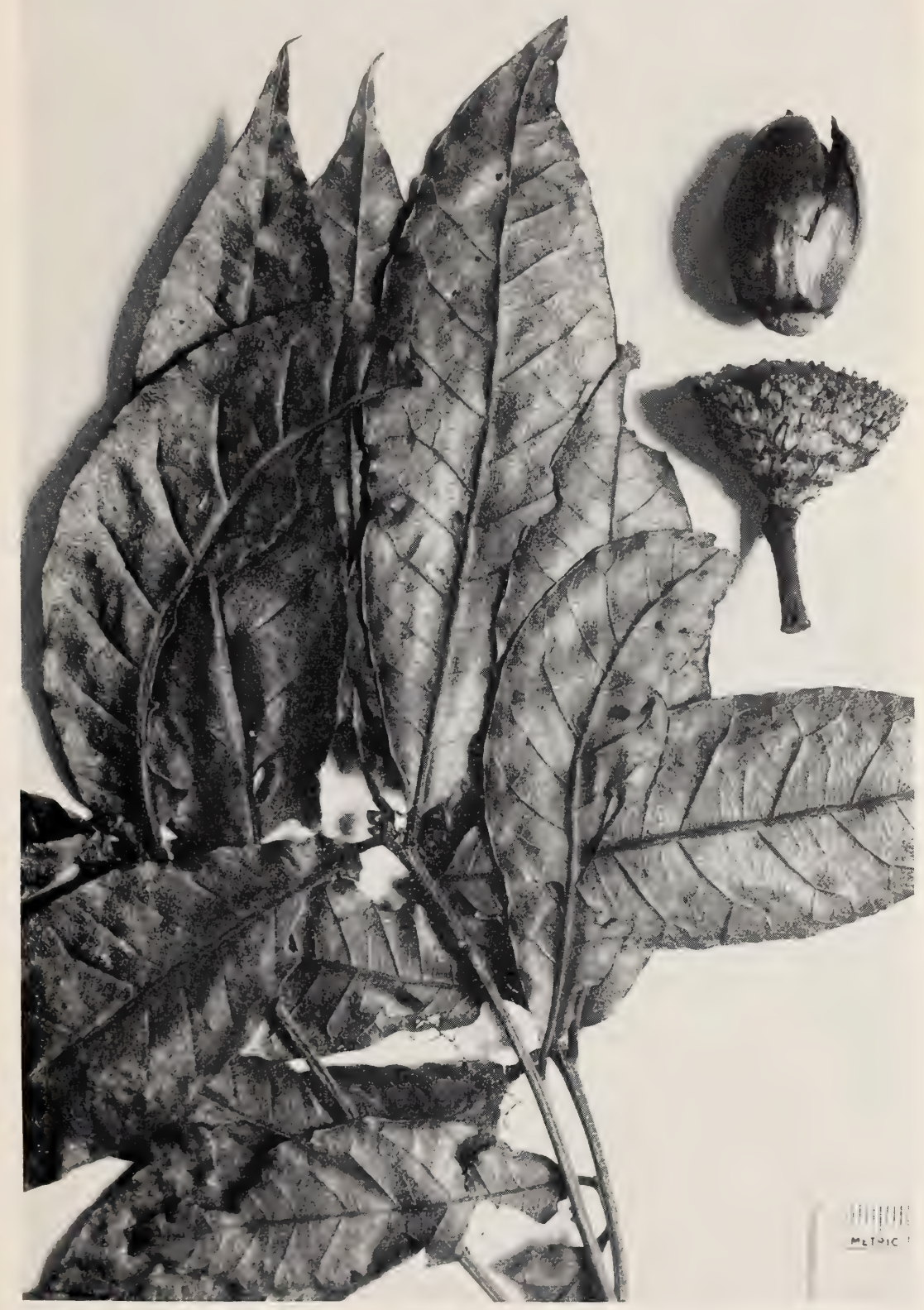

Quercus panamandinaea sp. nov. Type from Panama (Woodson and Schery 360$\mathrm{MBC})$. 


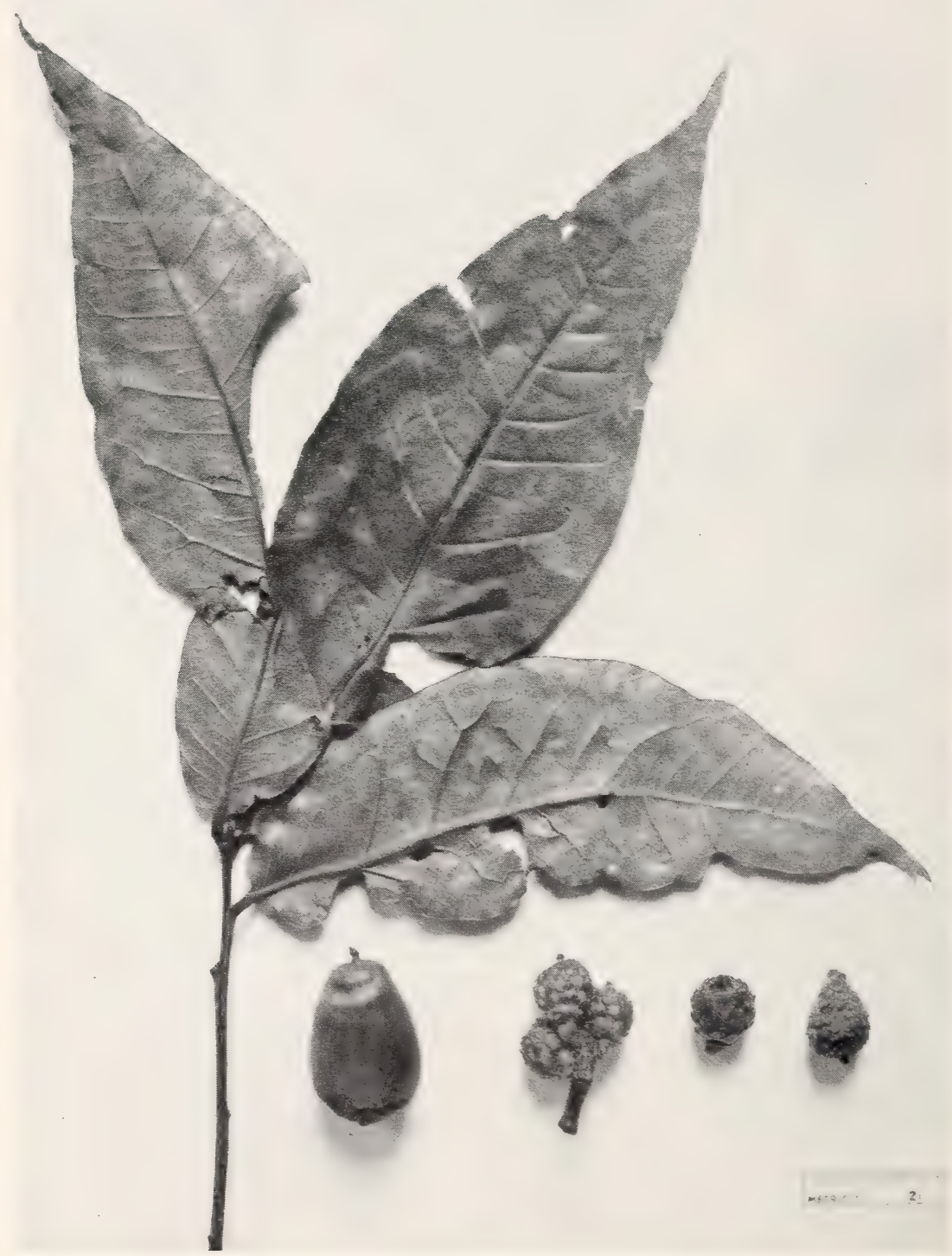

Quercus panamandinaea sp. nov. Isotype (IToodson and Schery 360-I'SNA). 


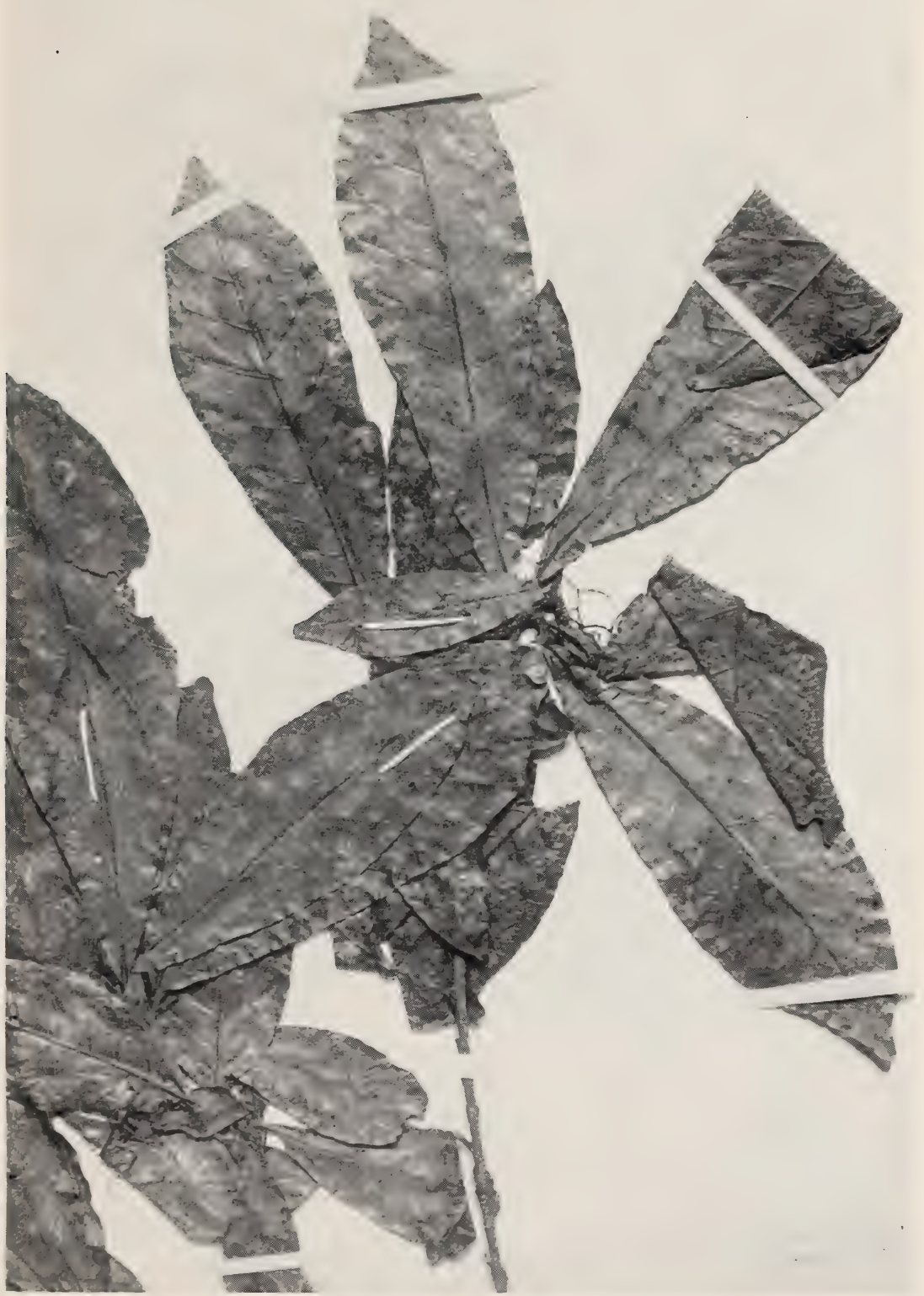

Quercus aáata sp. nov. Type from Guatemala (Standley 58466-F). 


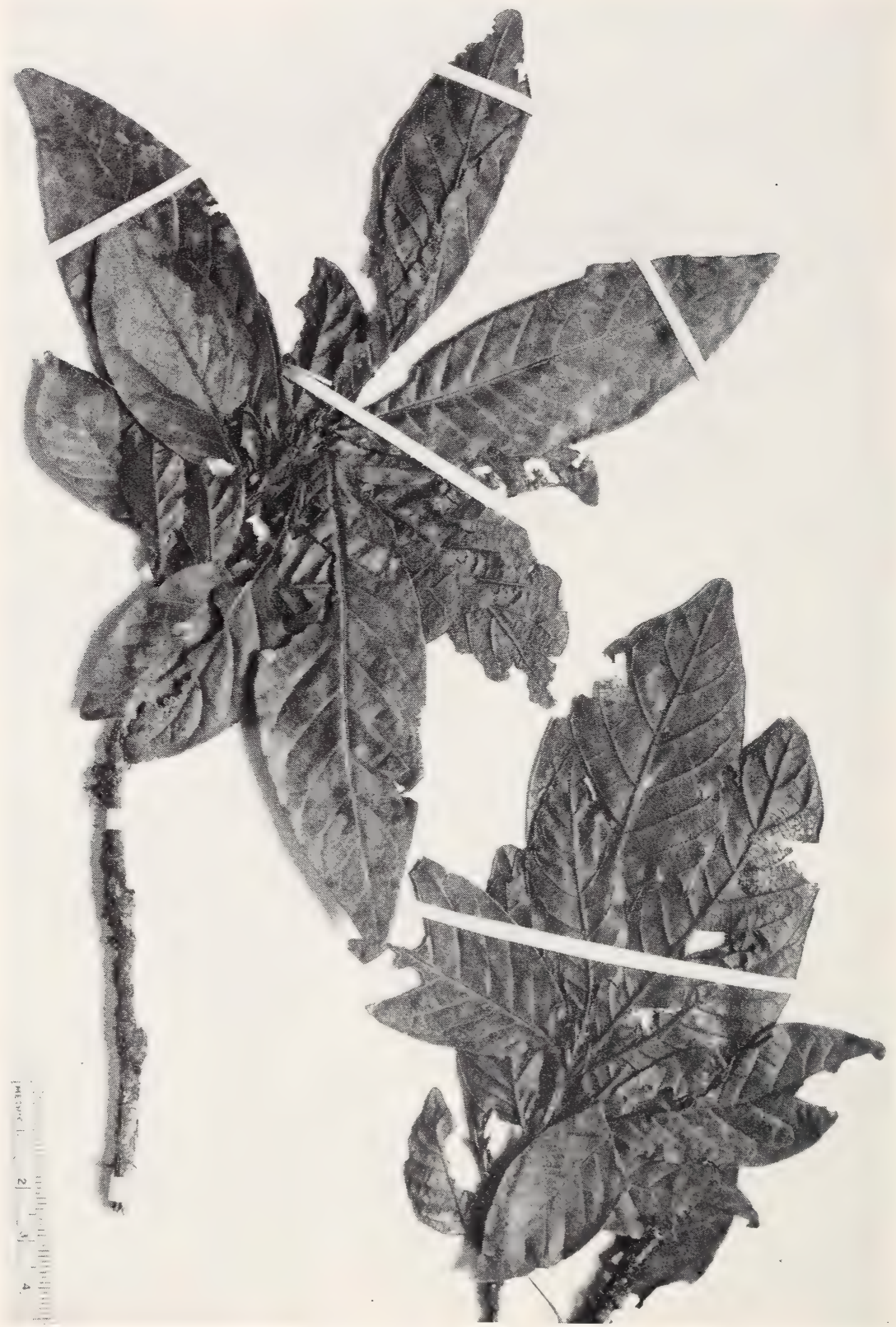

Quercus aáata sp. nov. Representative specimen from Costa Rica (Standley and Valerio 50651-US). 


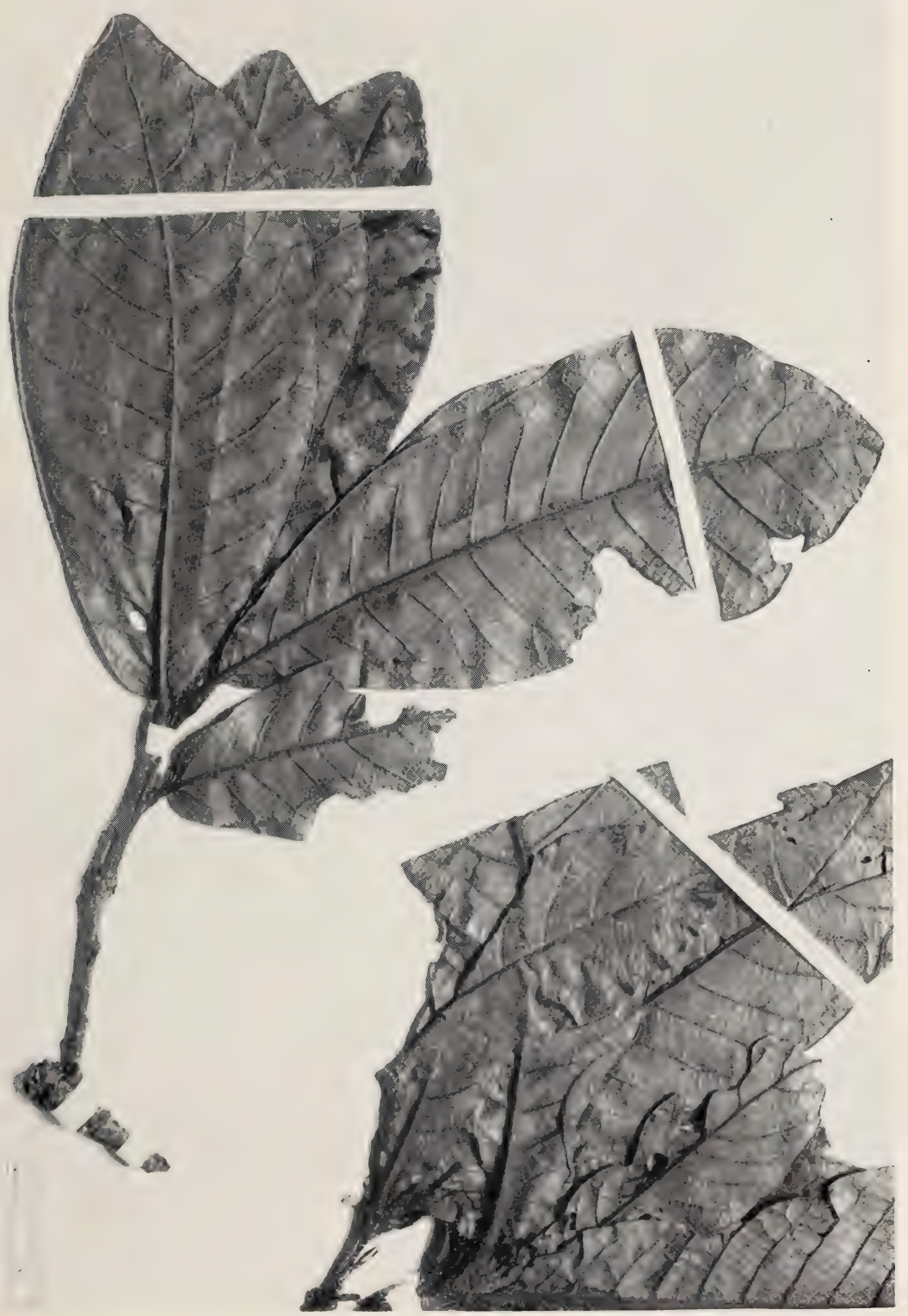

Quercus aáata sp. nov. A variant from ('osta Rica (Standley and Valerio 52178-. US). 


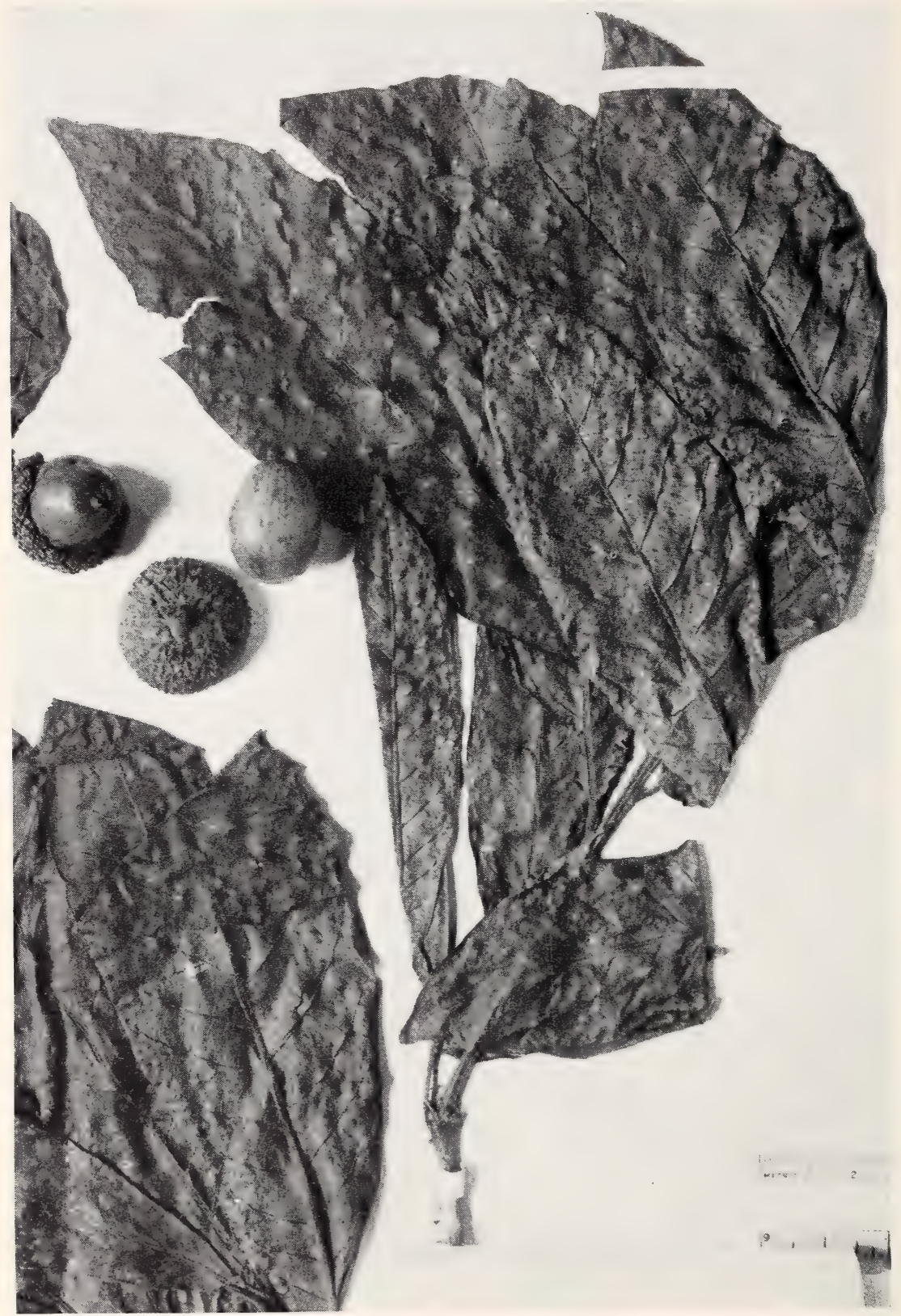

Quercus aáata sp. nov. Fruiting specimen from Honduras (Edwards 18-AA). 


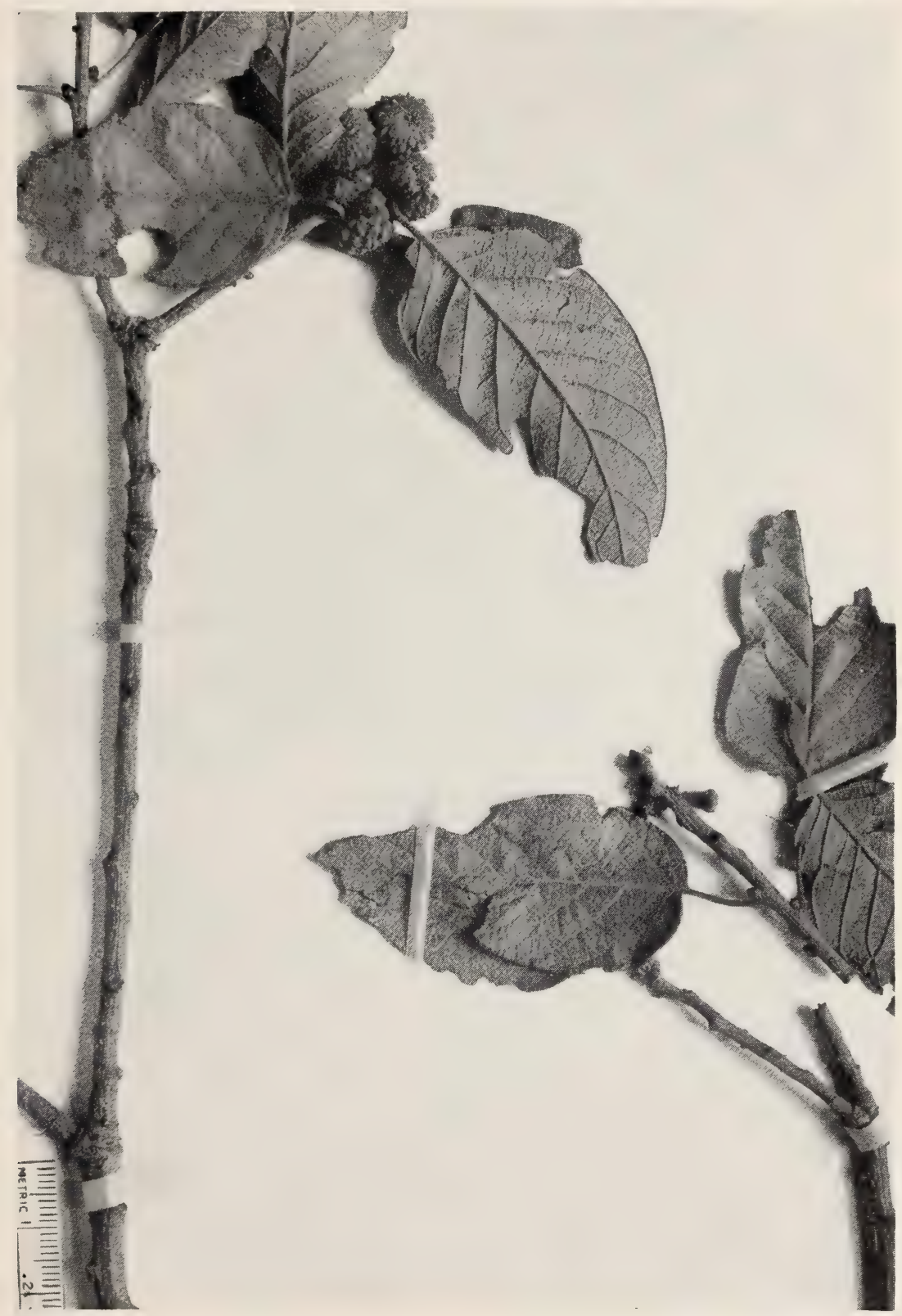

Quercus polymorpha Schlecht. and Cham. From Guatemala (Seler 3067-G). 
Miscellaneous Publication 477, U, S, Dept, of Agriculture

PLATE 28

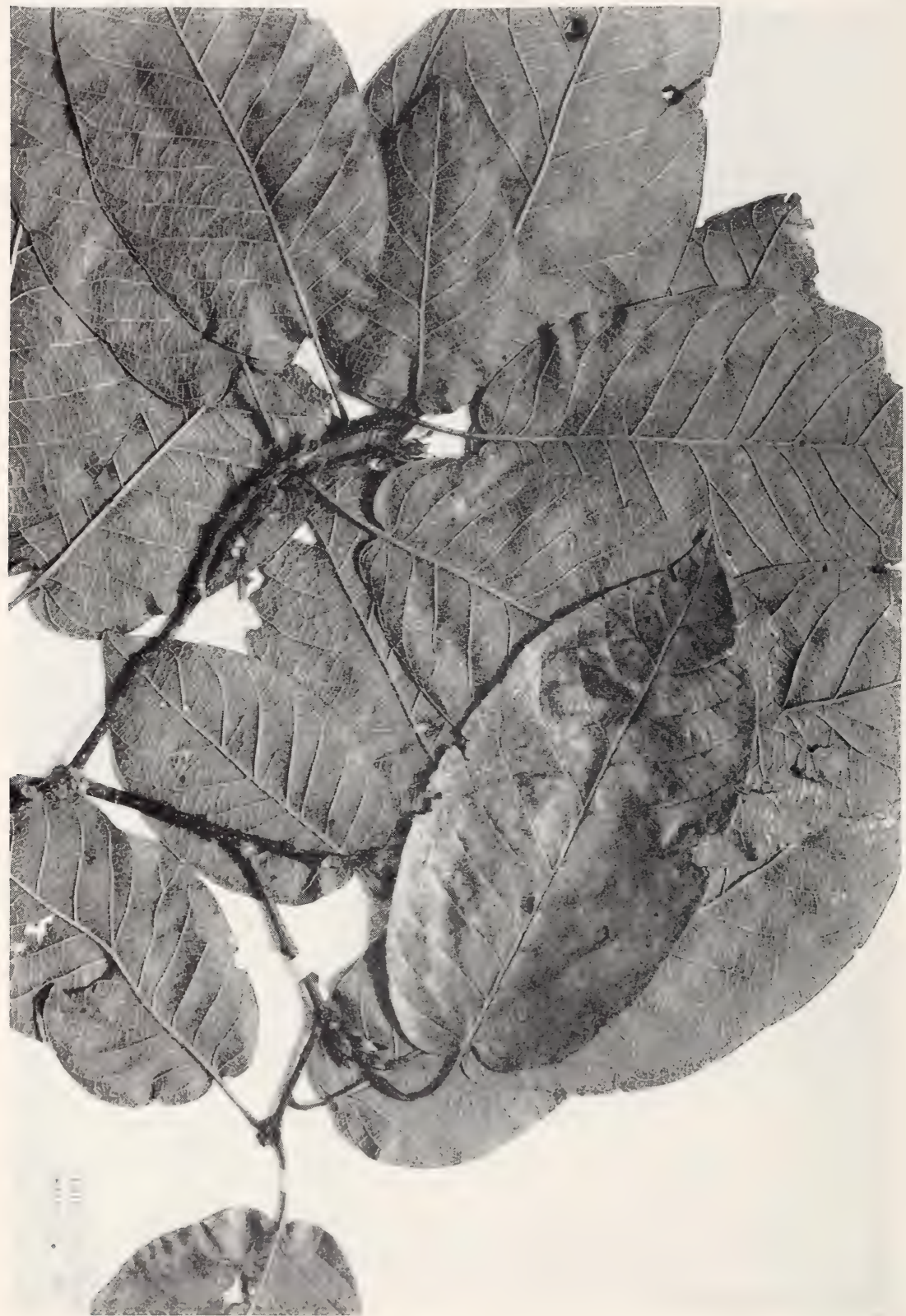

Quercus polymorpha Schlecht, and Cham. A common form from Guatemala (Steyermark $32966-\mathrm{F})$. 


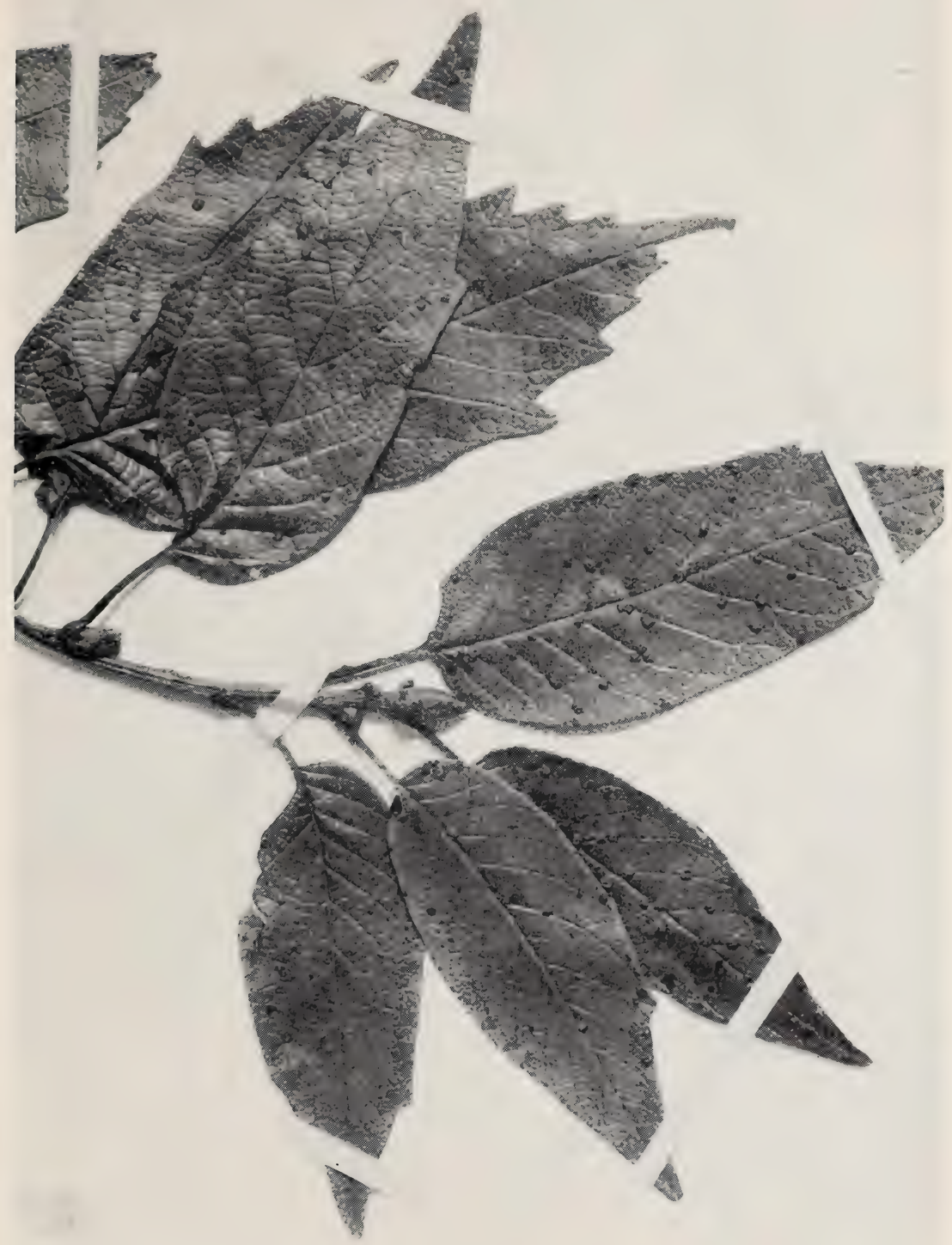

Quercus polymorpha Schlecht. and Cham. A representative specimen from Guatemala (Steyermark 32973-F). 


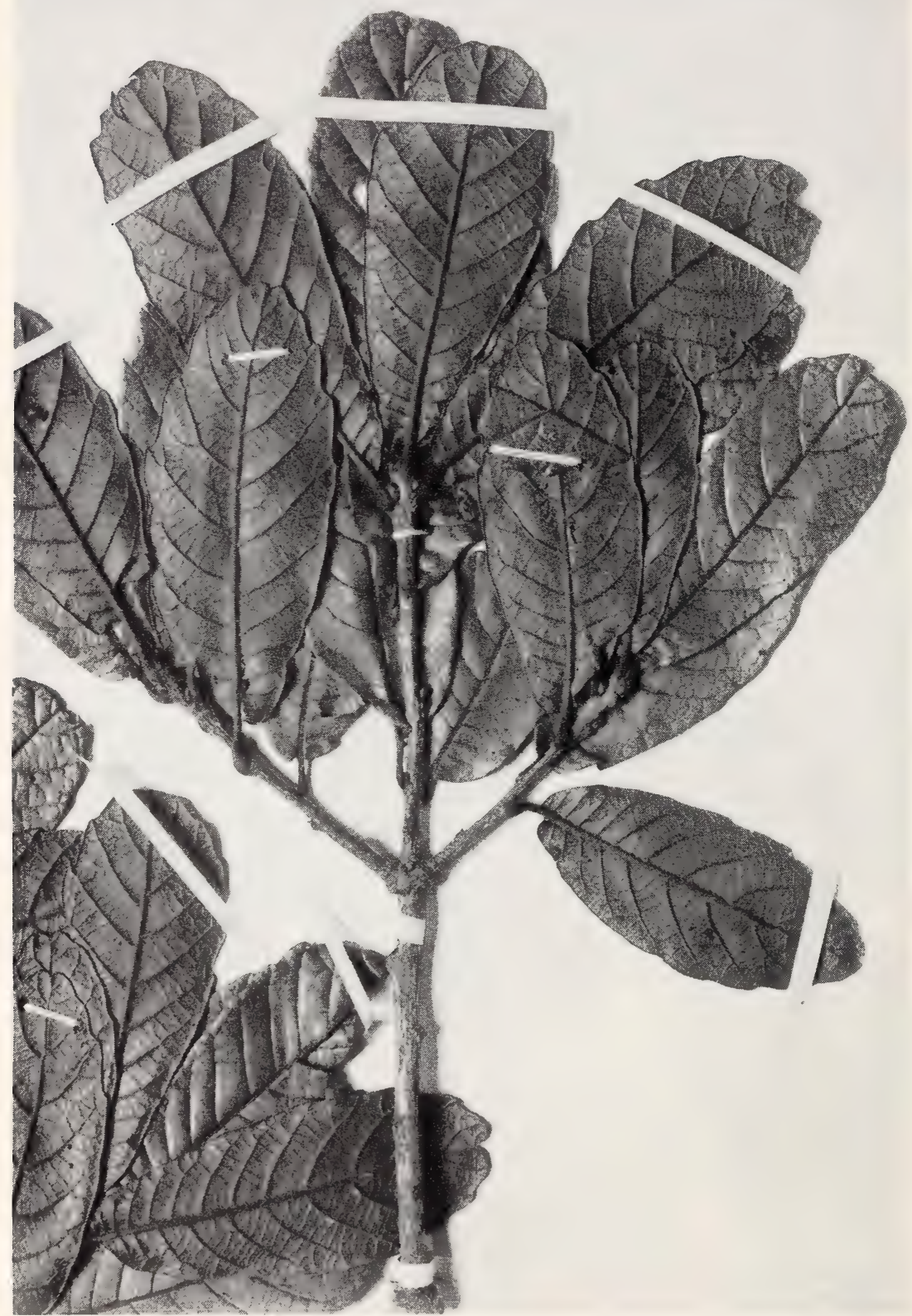

Quercus pacayana sp. nov. Type from Guatemala (Standley 58467-F). 


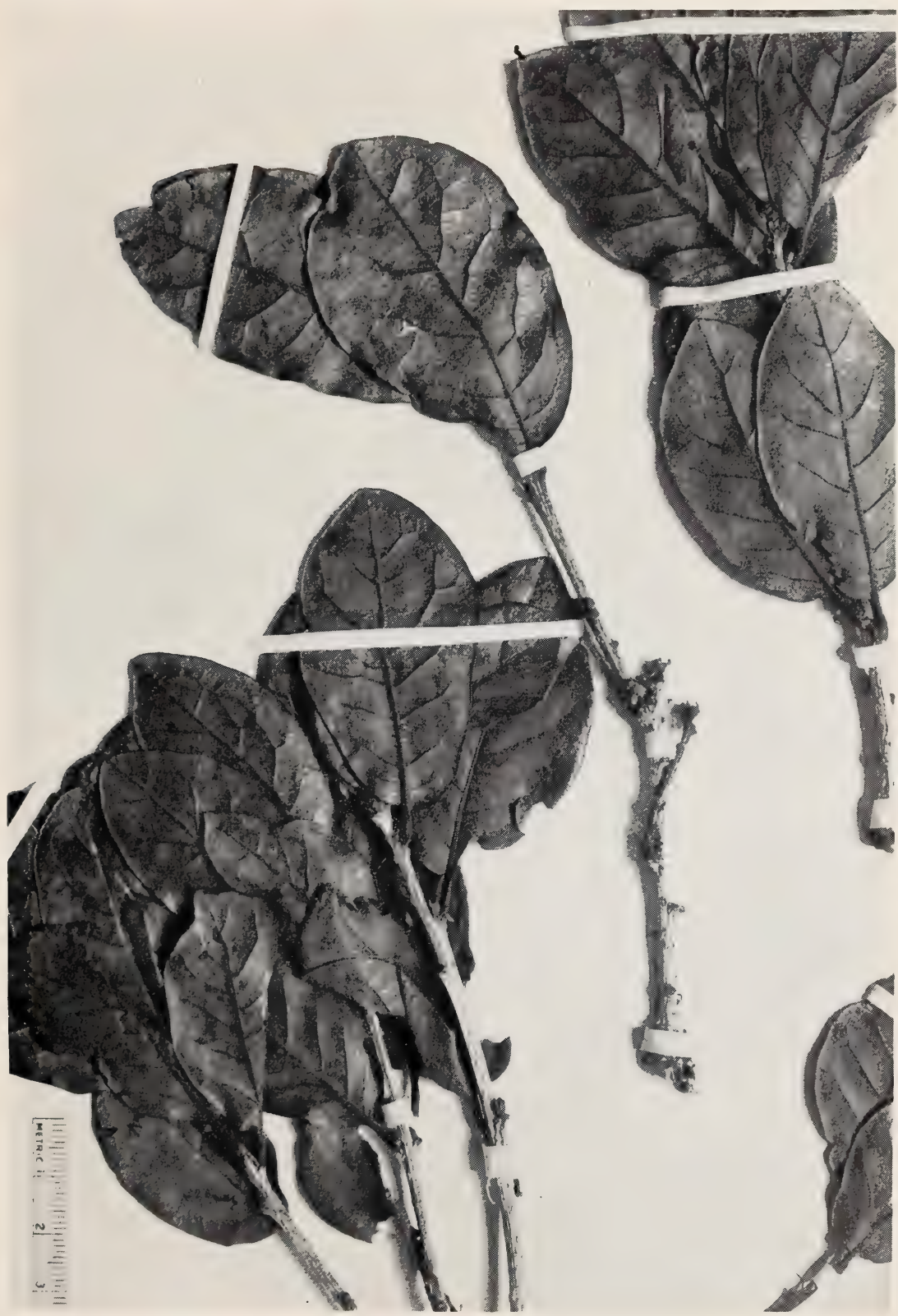

Quercus copeyensis sp. nov. Type from Costa Rica (Standley 42583-US). 


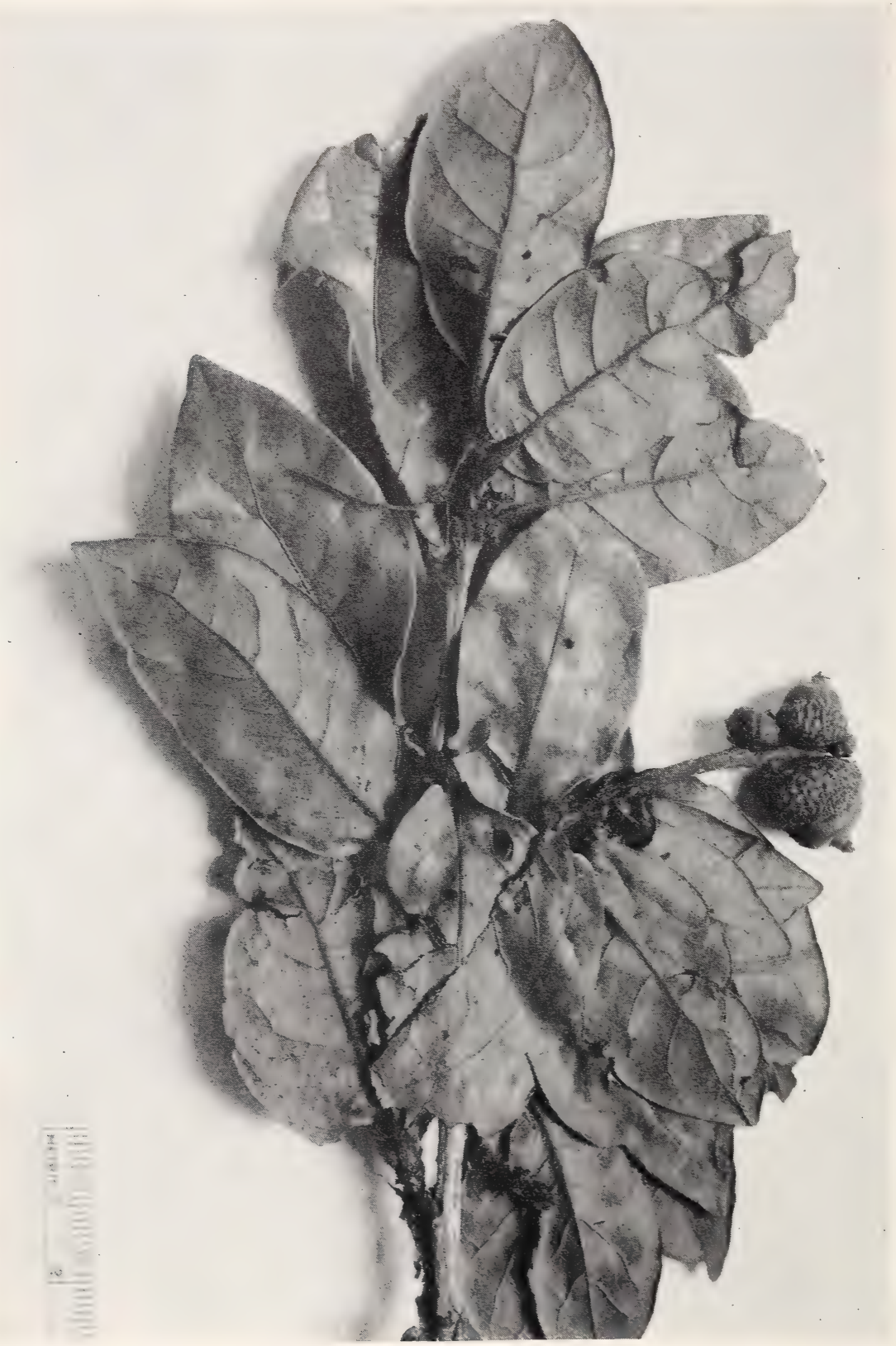

Quercus copeyensis sp. nov. Representative specimen from Panama (Woodson and Schery 383-USNA). 


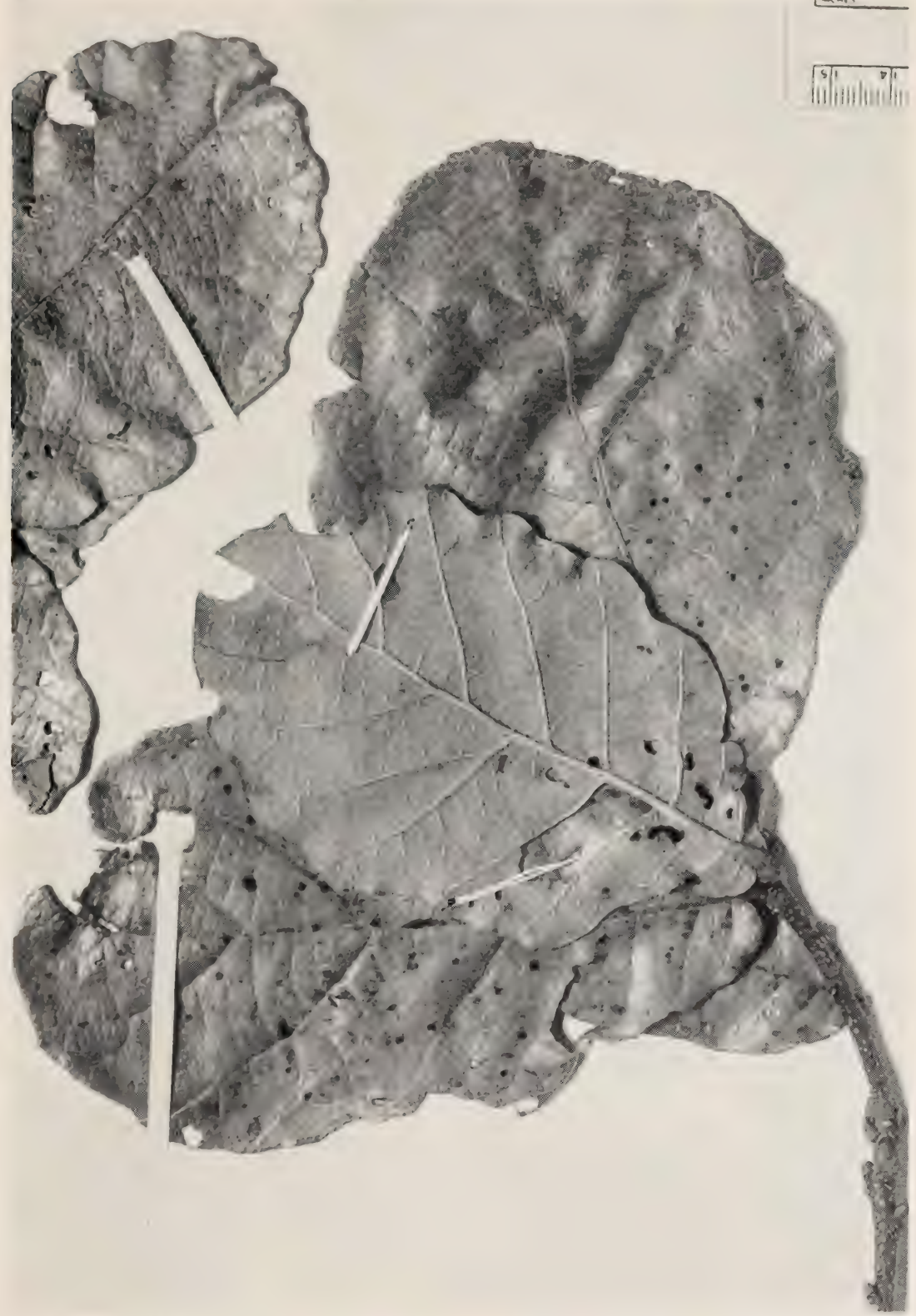

Quercus scgovicnsis Liebm. Representative specimen from Guatemala (Standley $65653-\mathrm{F})$. 
Misceilaneous Publication 477, U. S. Dept. of Agriculture

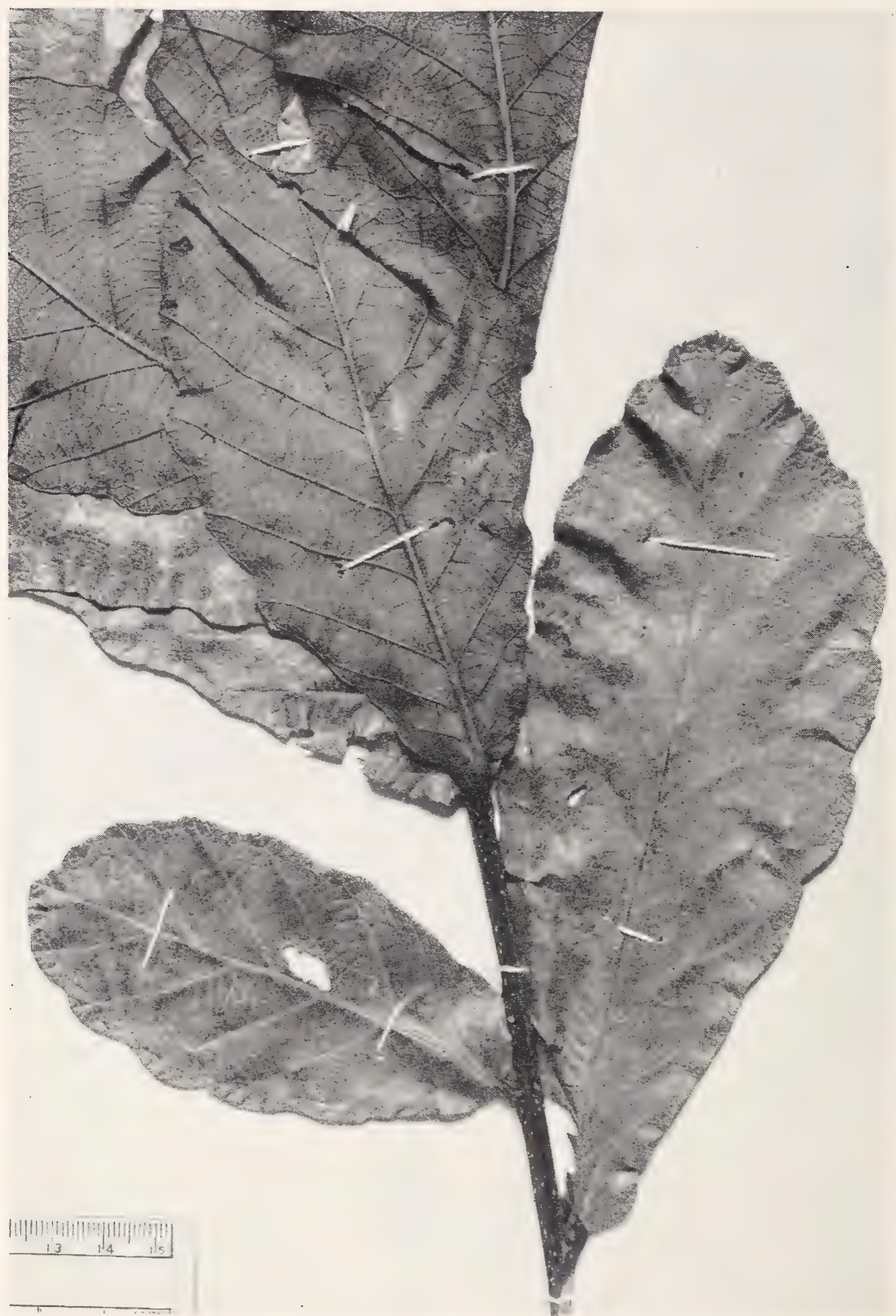

Quercus segoviensis Liebm. Representative specimen from Honduras (Standley 55930 - US). 


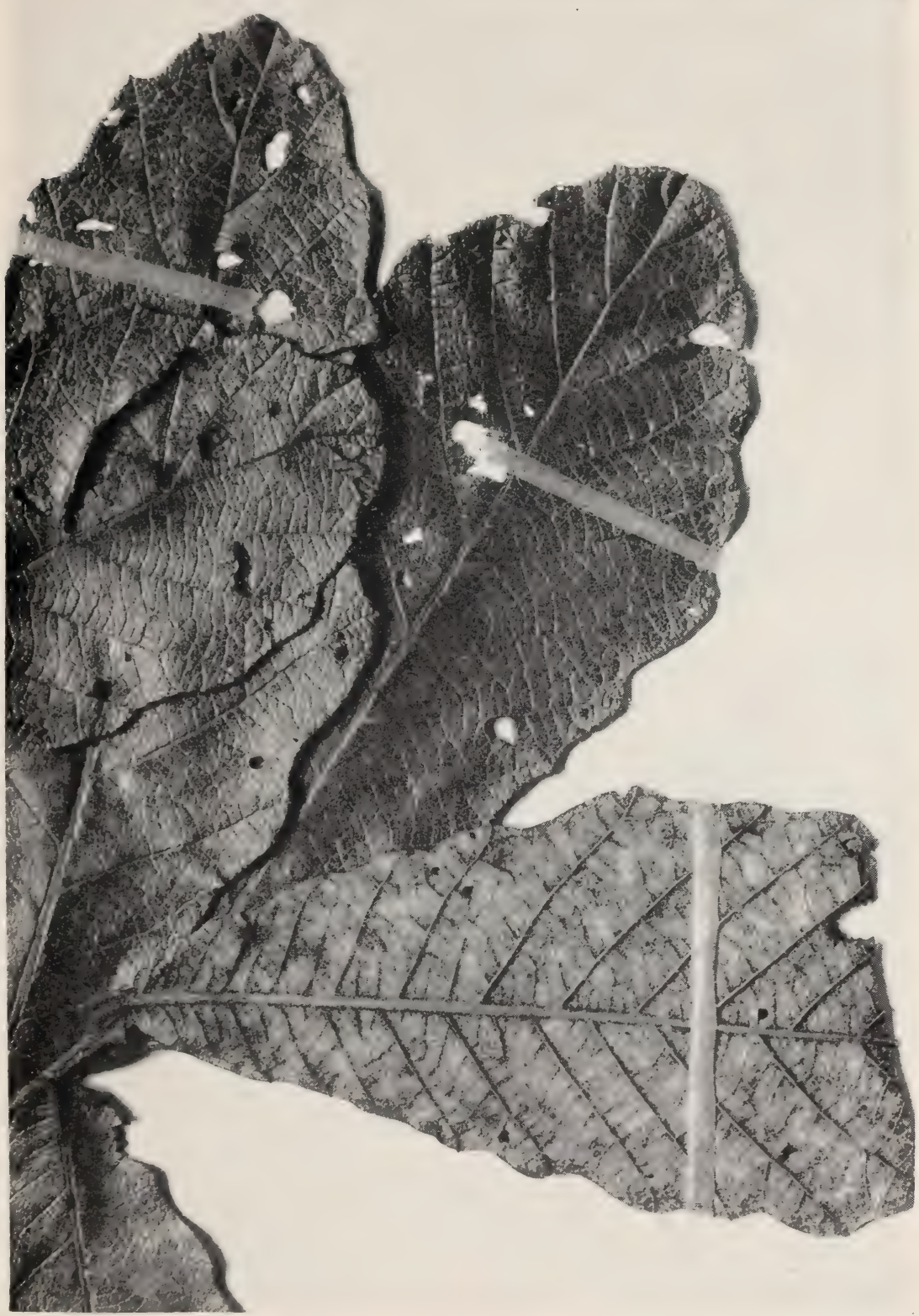

Quercus peduncularis Nee. A representative specimen from Guatemala (Kellerman 5658 -US). 
Miscellaneous Publication 477, U. S. Dept. of Agriculture

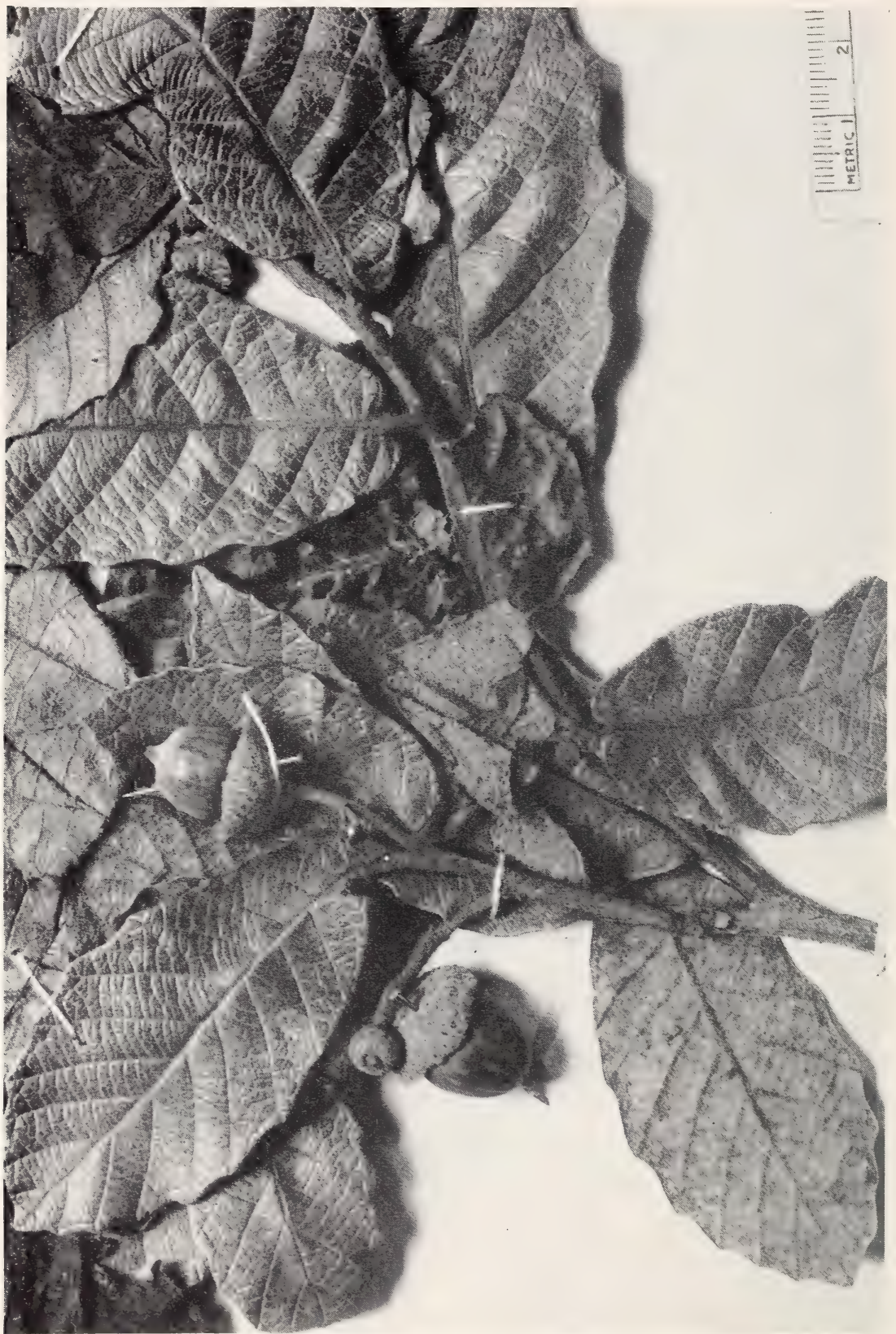

Quercus peduncularis Nee. A characteristic specimen from Guatemala (Tonduz 739-US). 


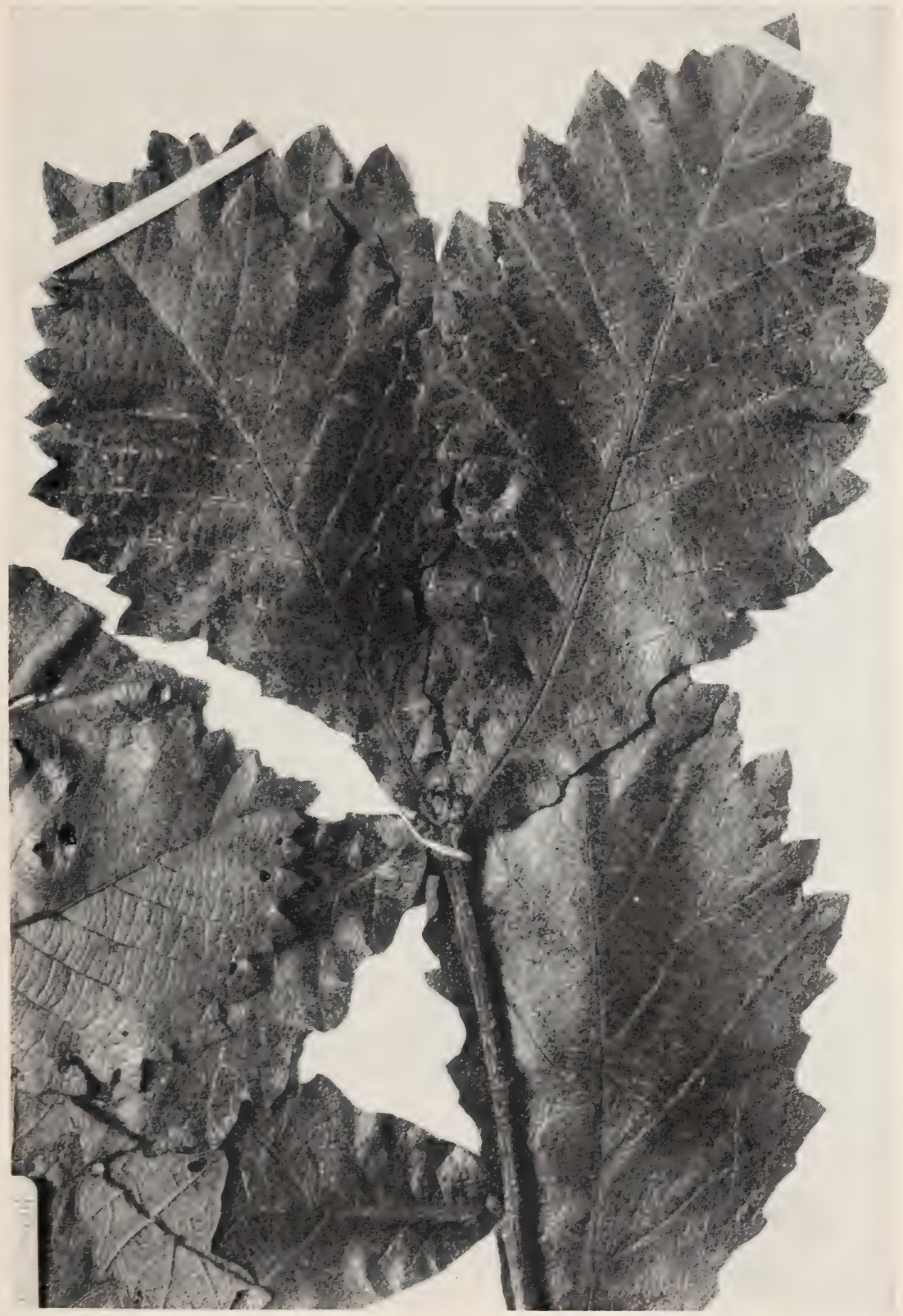

Quercus peduncularis Nee. A variant from Guatemala (Standley 62451-F). 


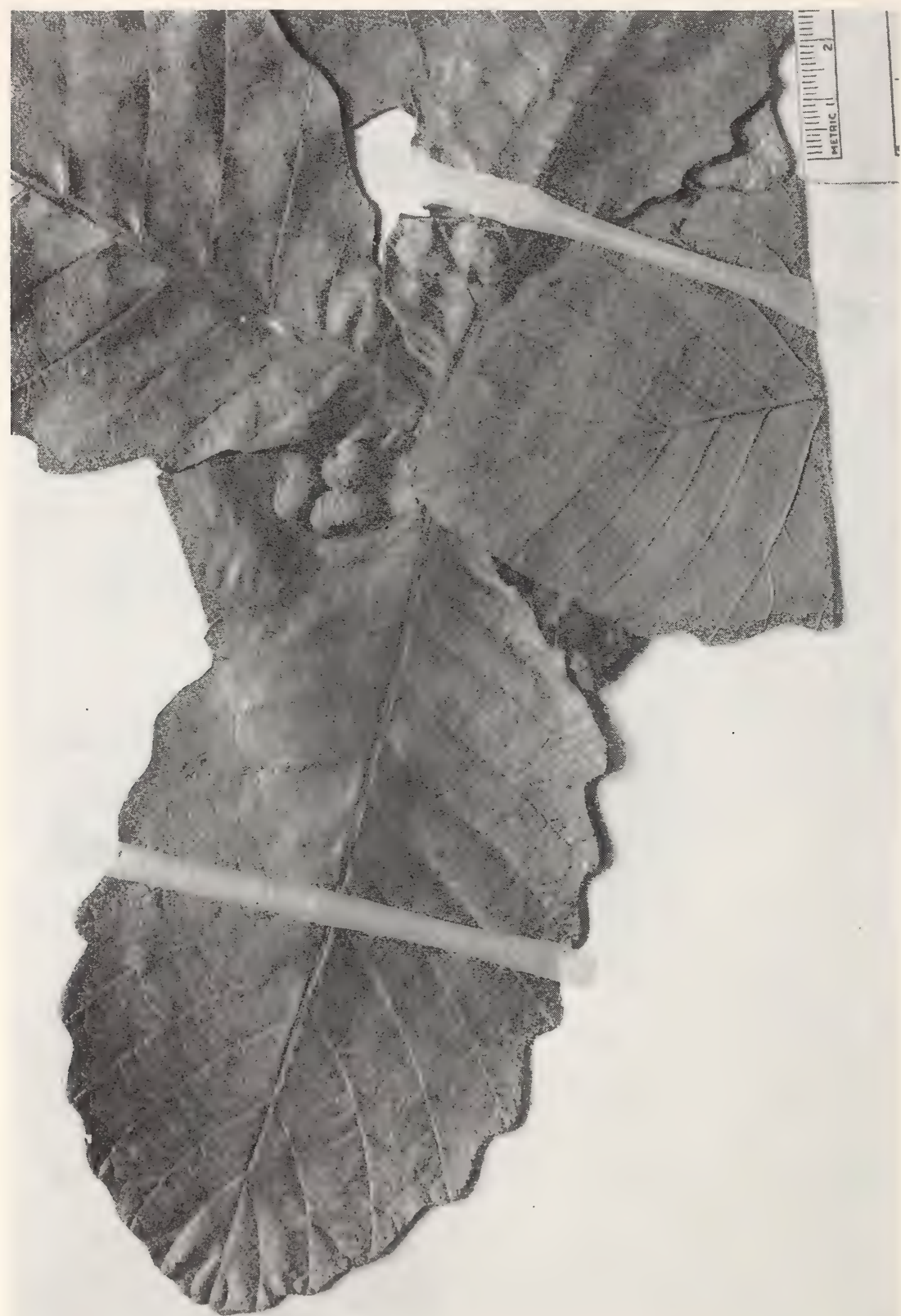

Quercus peduncularis var. sublanosa (Trel.) comb. nov. A representative specimen from Guatemala (Cook and Doyle 280-US). 


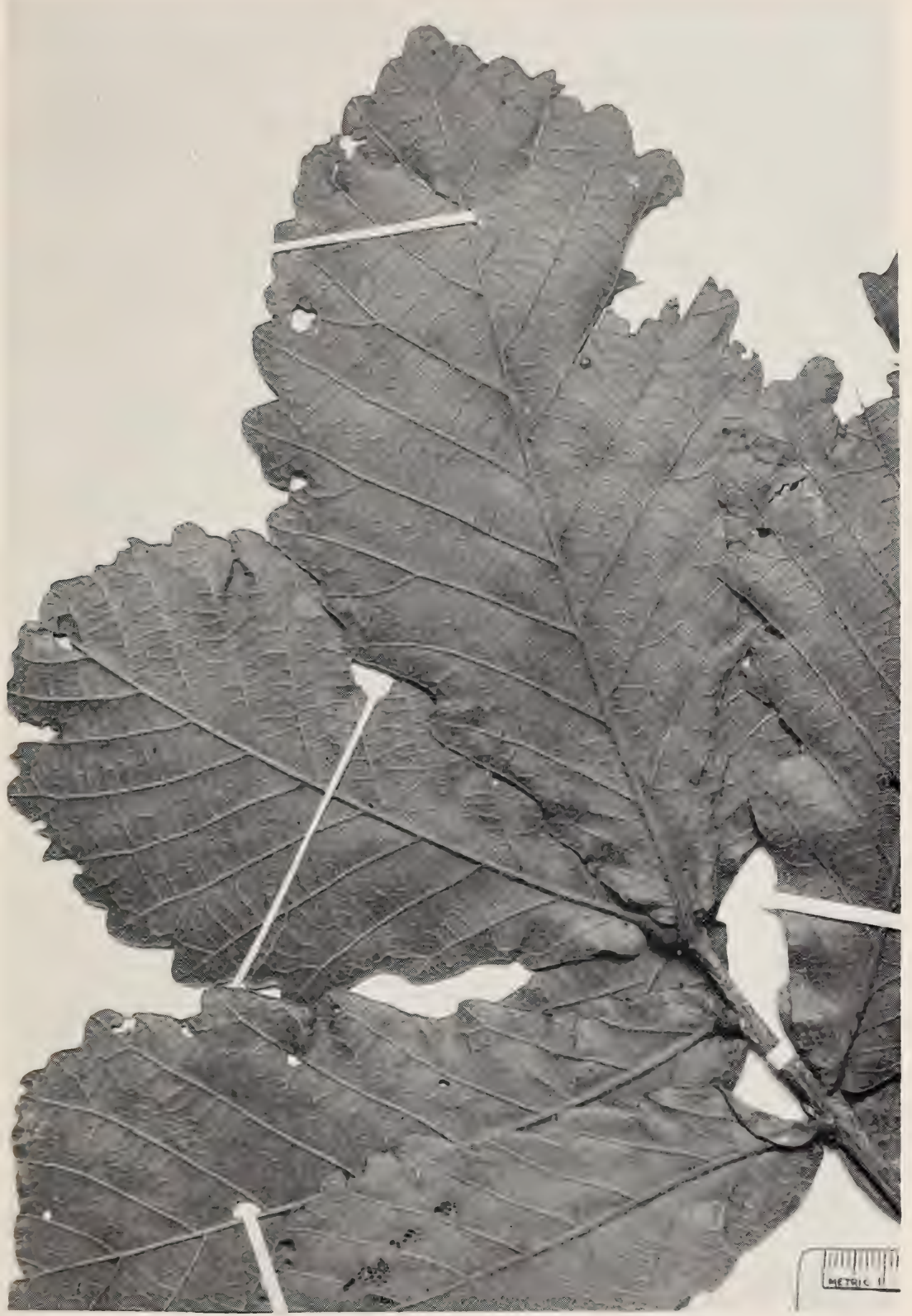

Quercus peduncularis var. sublanosa (Trel.) comb. nov. A representative specimen from Honduras (Standley 56184-US). 


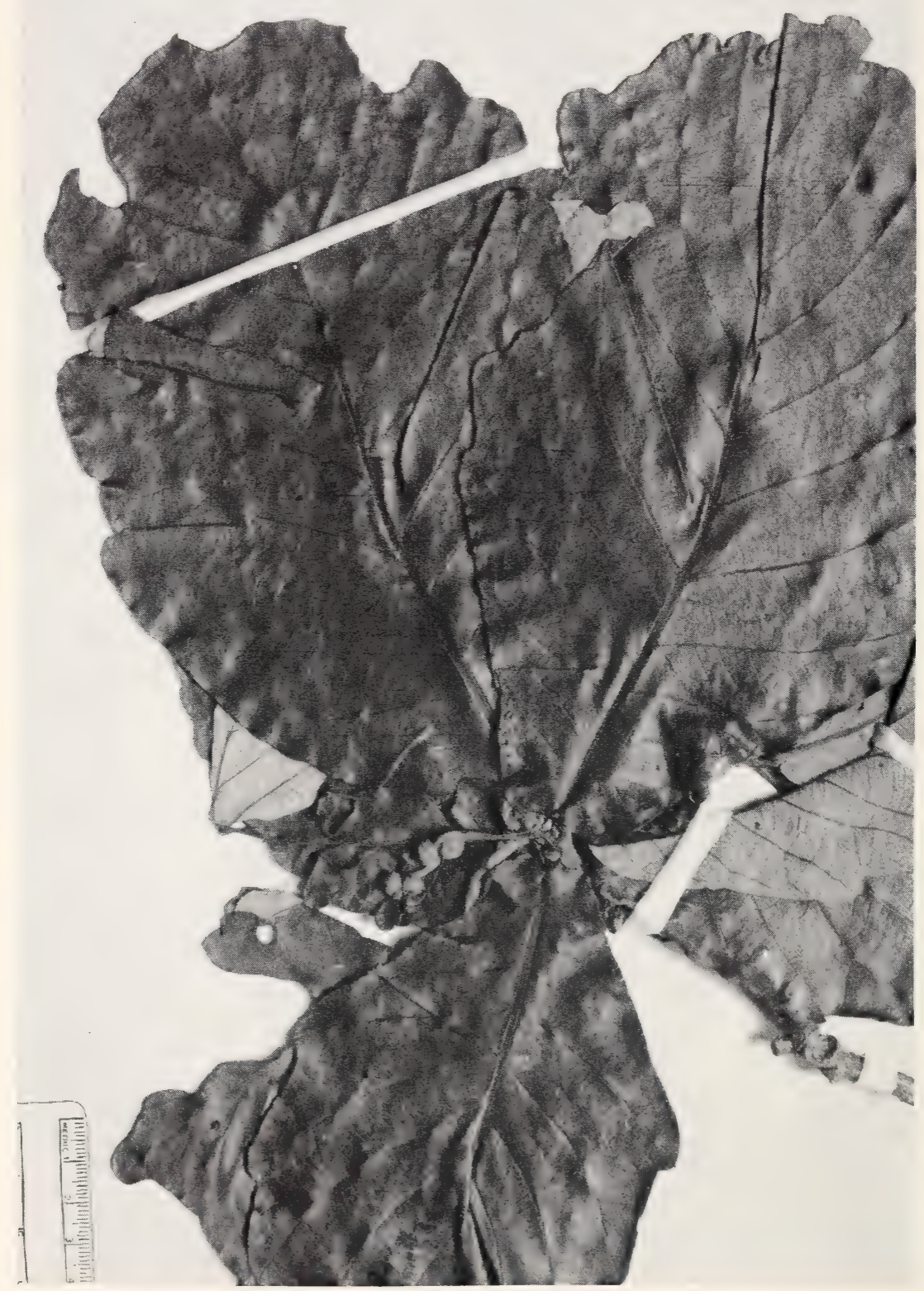

Quercus purulhana Trel. Type from Guatemala (Pittier 163-US). 


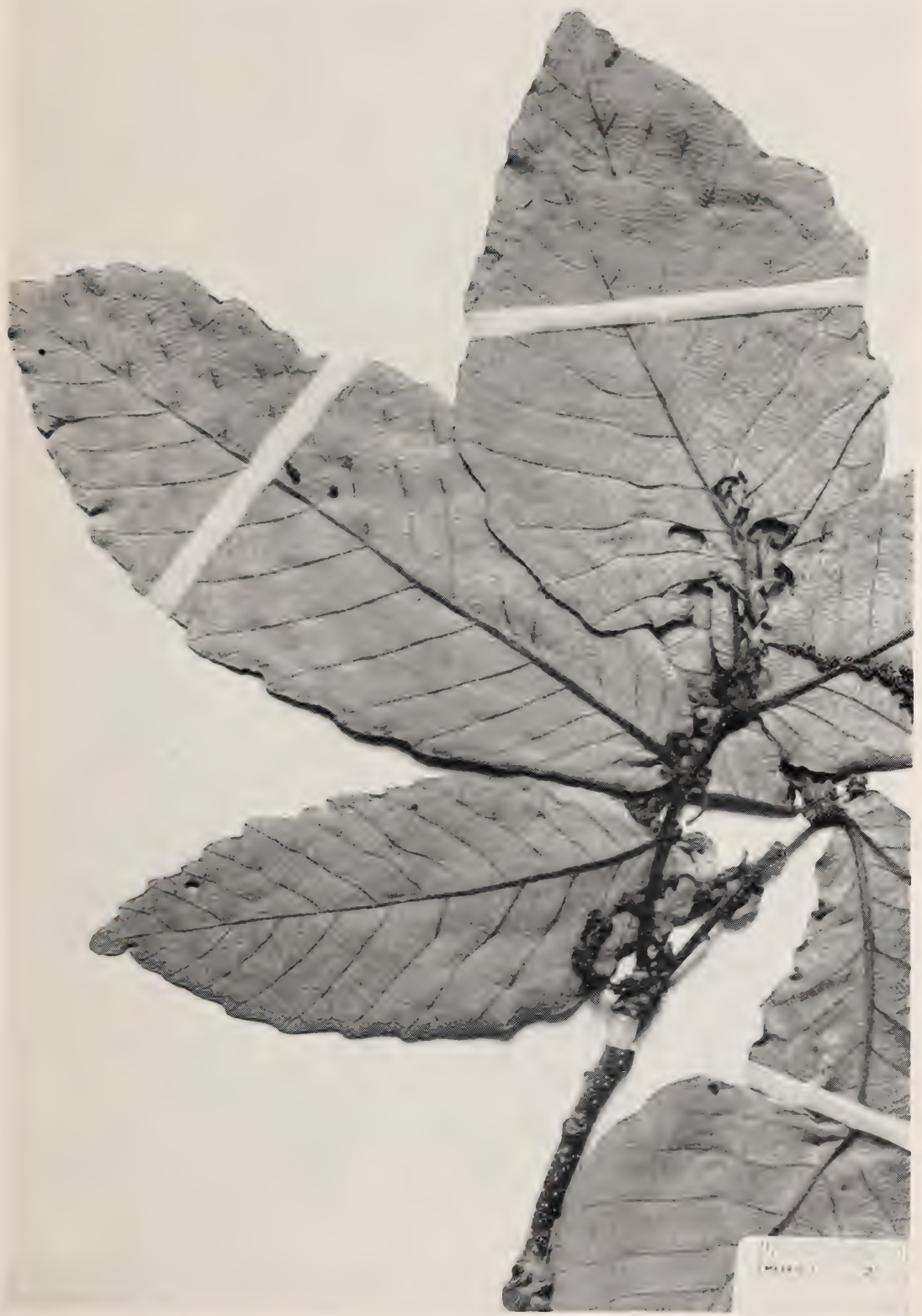

(uercus purulhana Trel. Isotype, more representative of the species than the type (Pittier 163-US). 


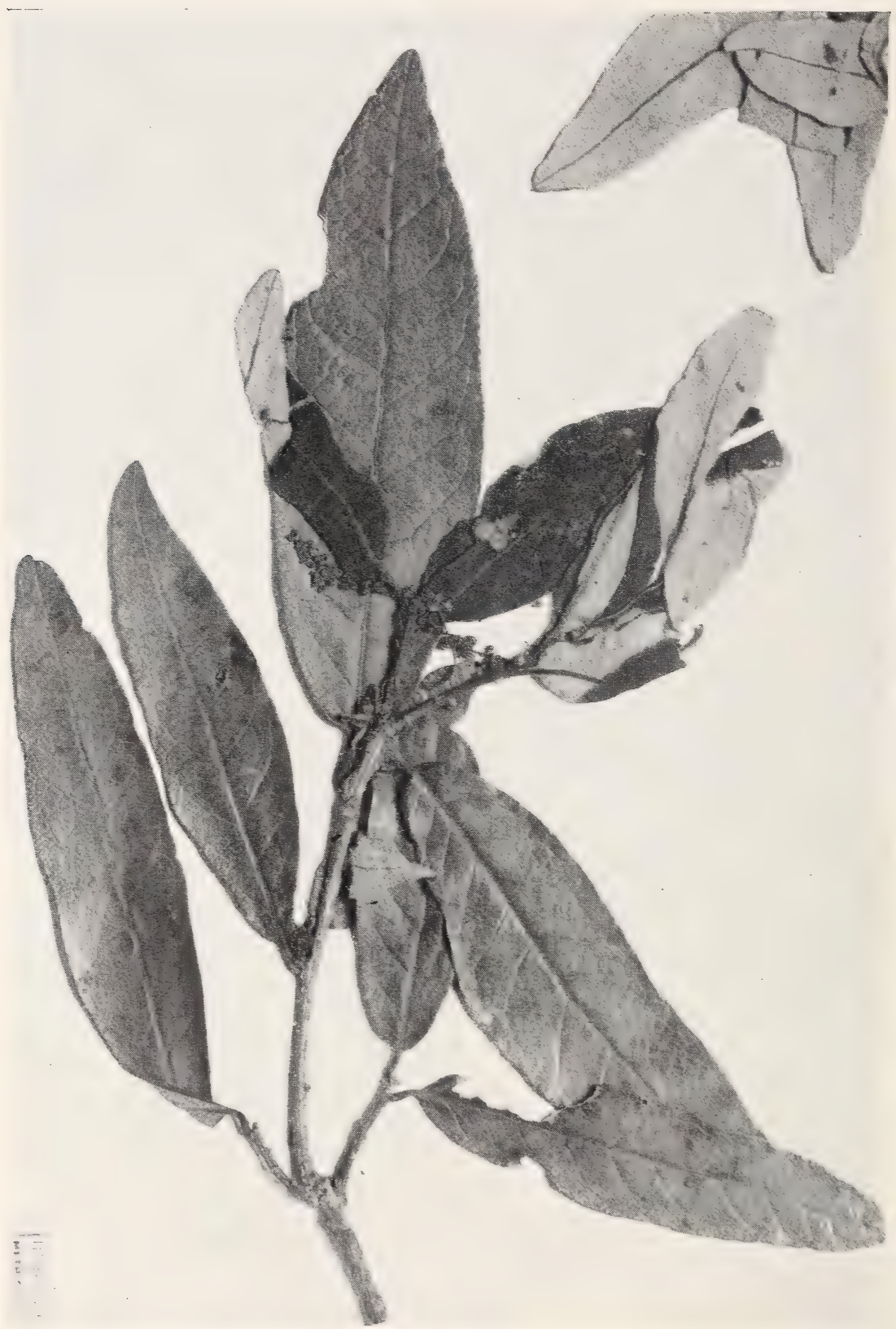

Quercus vicentensis Trel. Type from El Salvador (Standley 21593-L'S). 

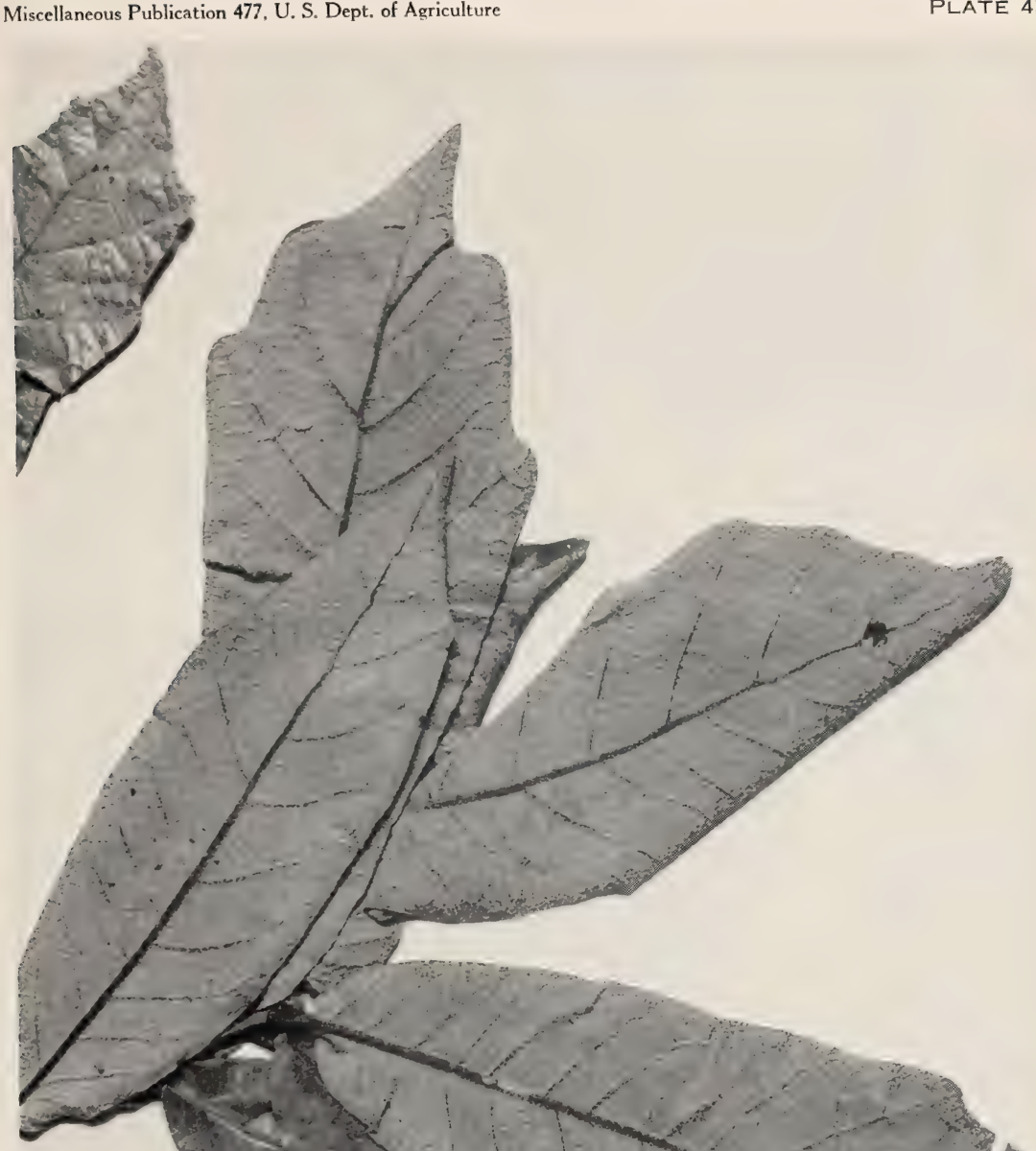

0
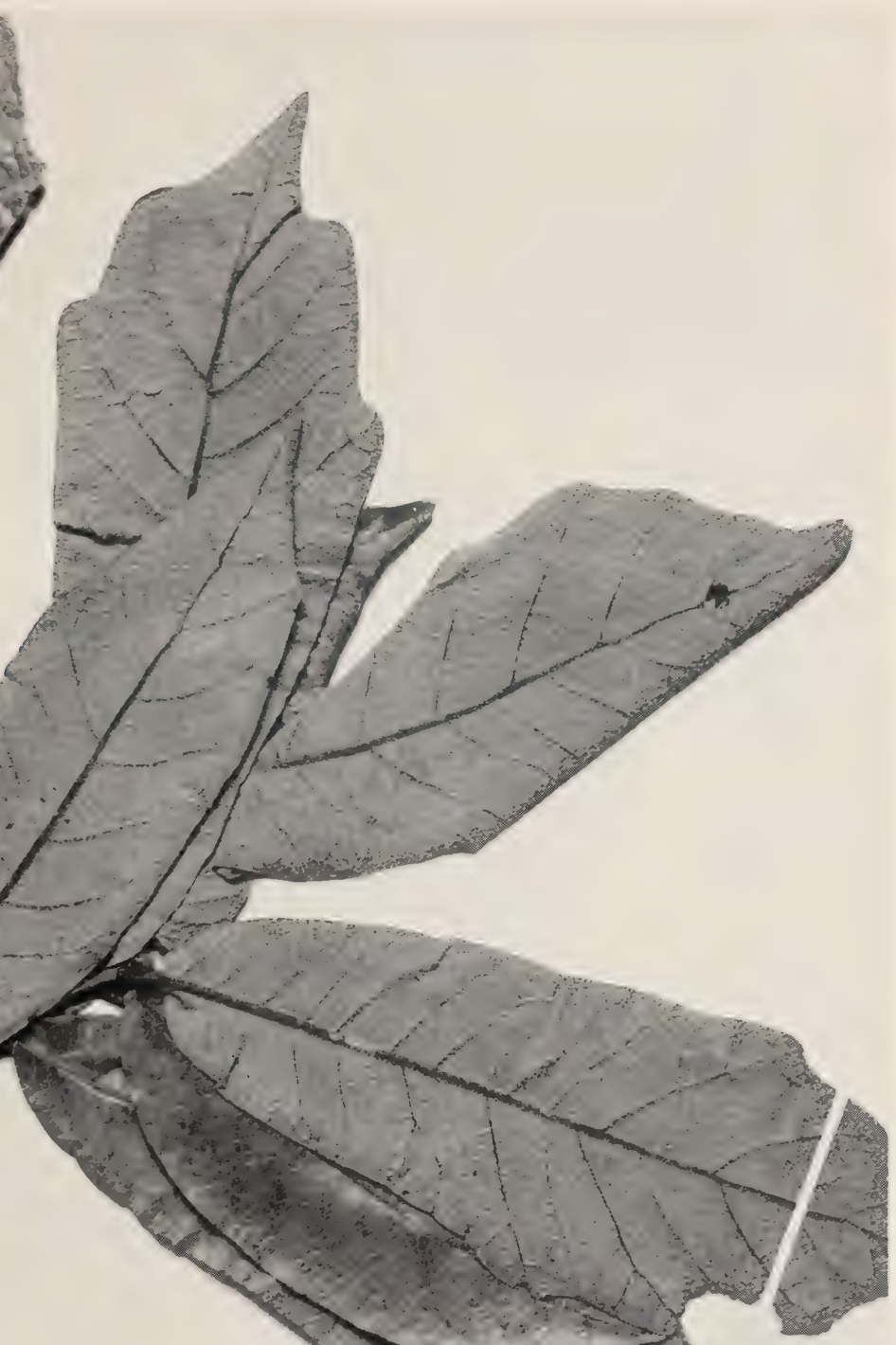

Quercus vicentensis Trel. Type of Q. comasaguana Trel, from El Salvador (Calderon 1430-US). 
Miscellaneous Publication 477, U. S. Dept. of Agriculture

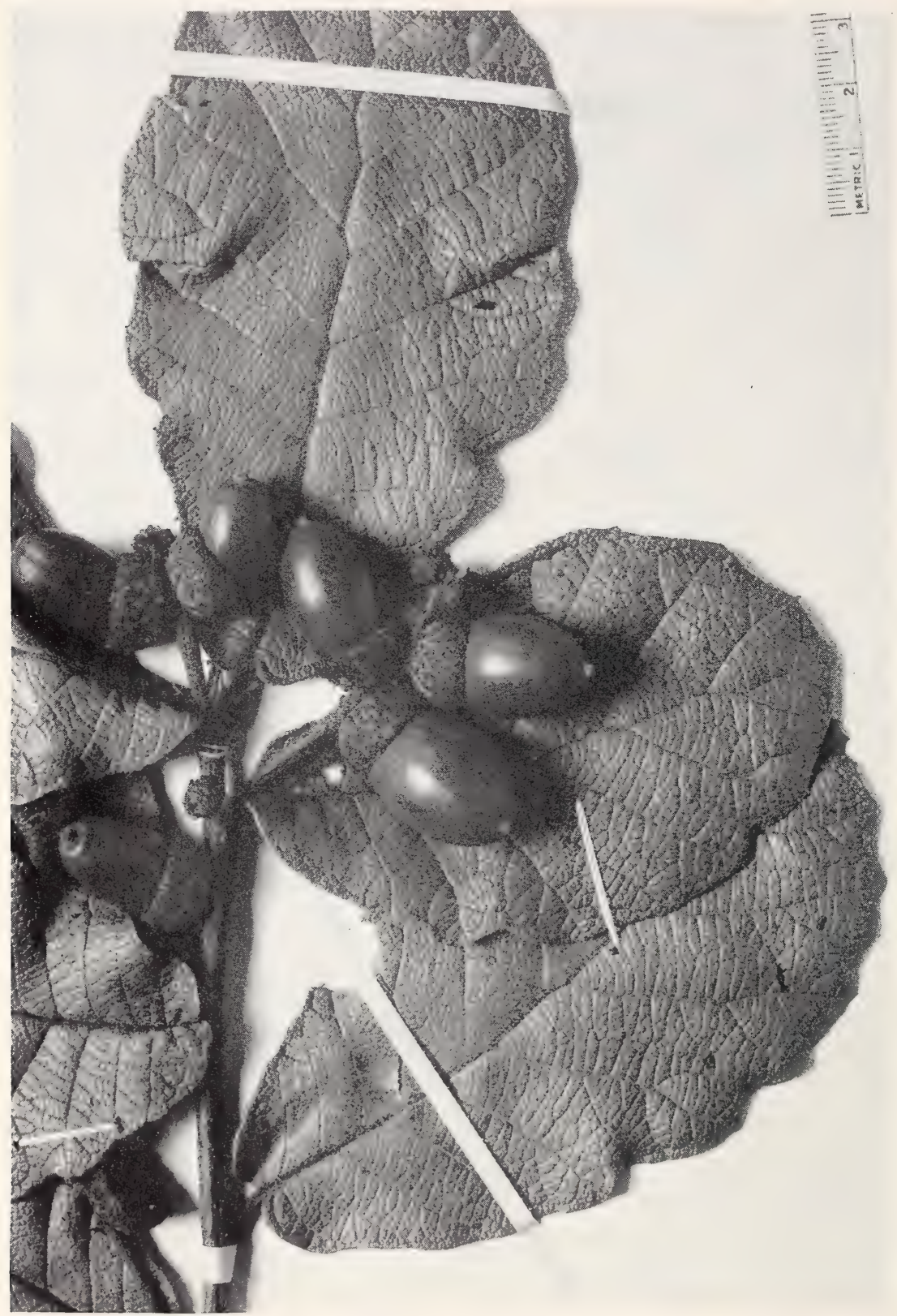

Quercus pilicaulis Trel. A representative specimen from Guatemala (Skutch 686US). 


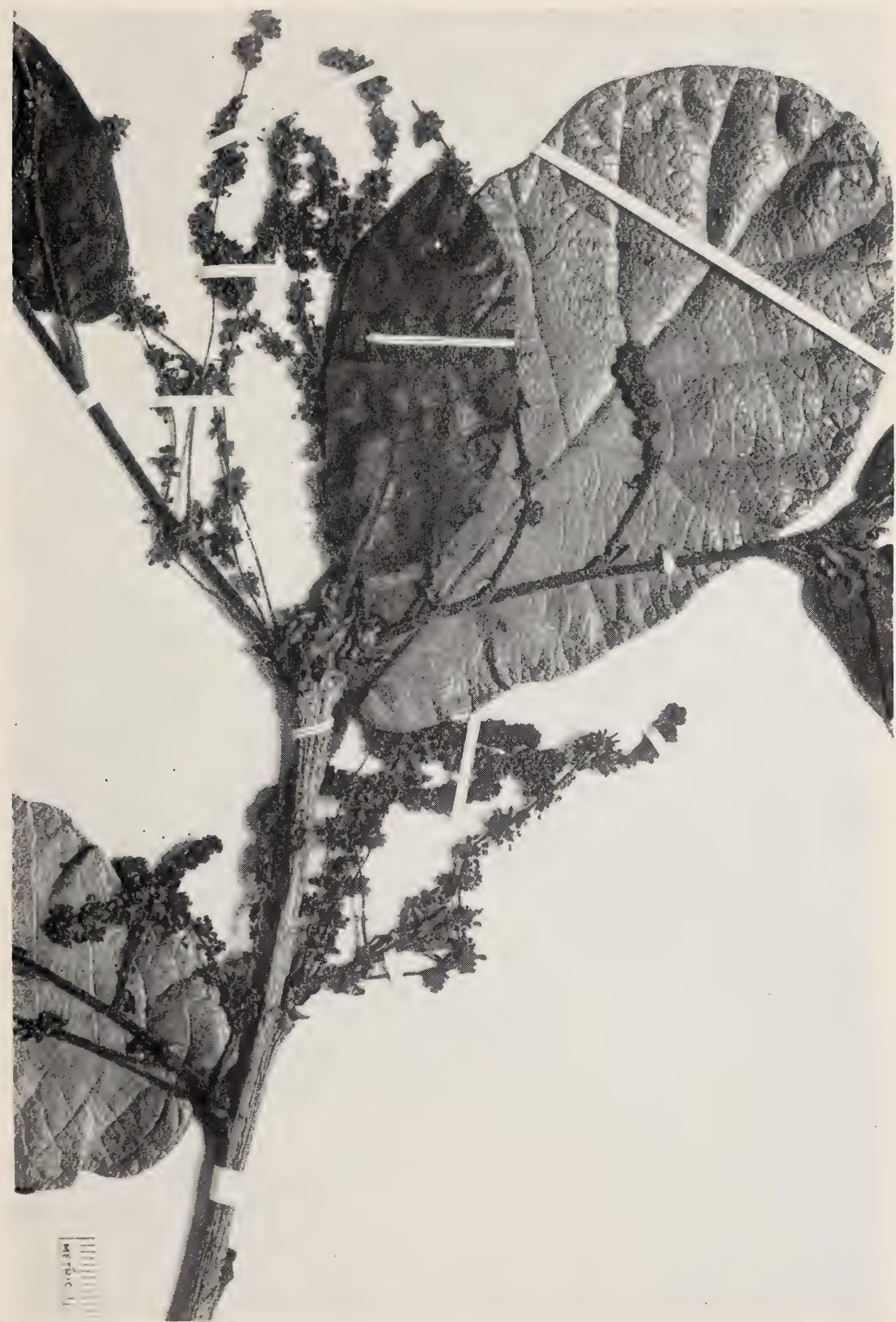

Quercus pilicaulis Trel. A representative specimen from Guatemala (Skutch 296US). 


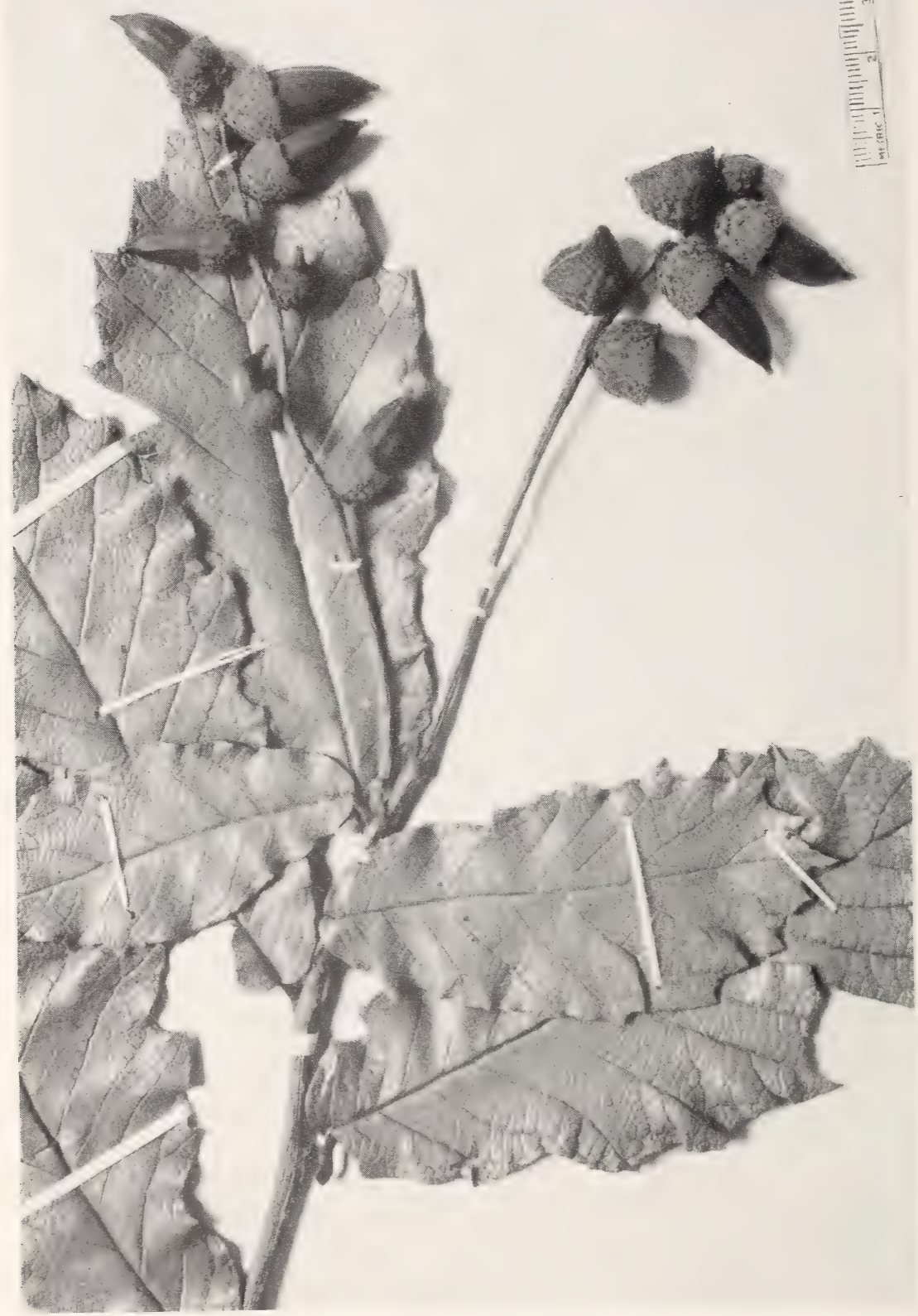

Quercus pilicaulis Trel. The type of f. elongata C. H. Mull., a variant from Guatemala (Skutch 687-US). 


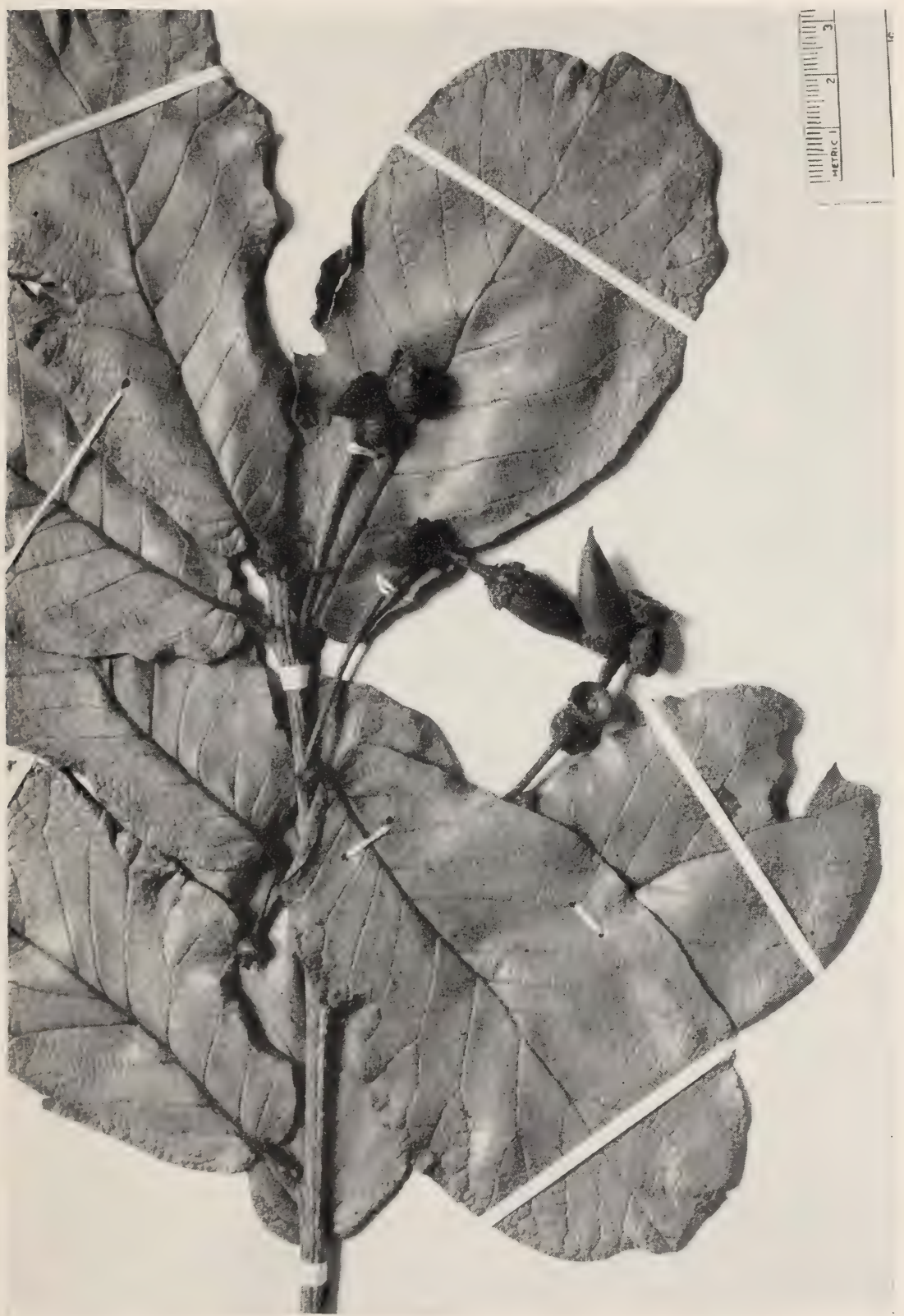

Quercus pilicaulis Trel. Type of f. exserta C. H. Mull., a variant from Guatemala (Skutch 661-US). 
Miscellaneous Publication 477, U. S. Dept. of Agriculture

PLATE 48

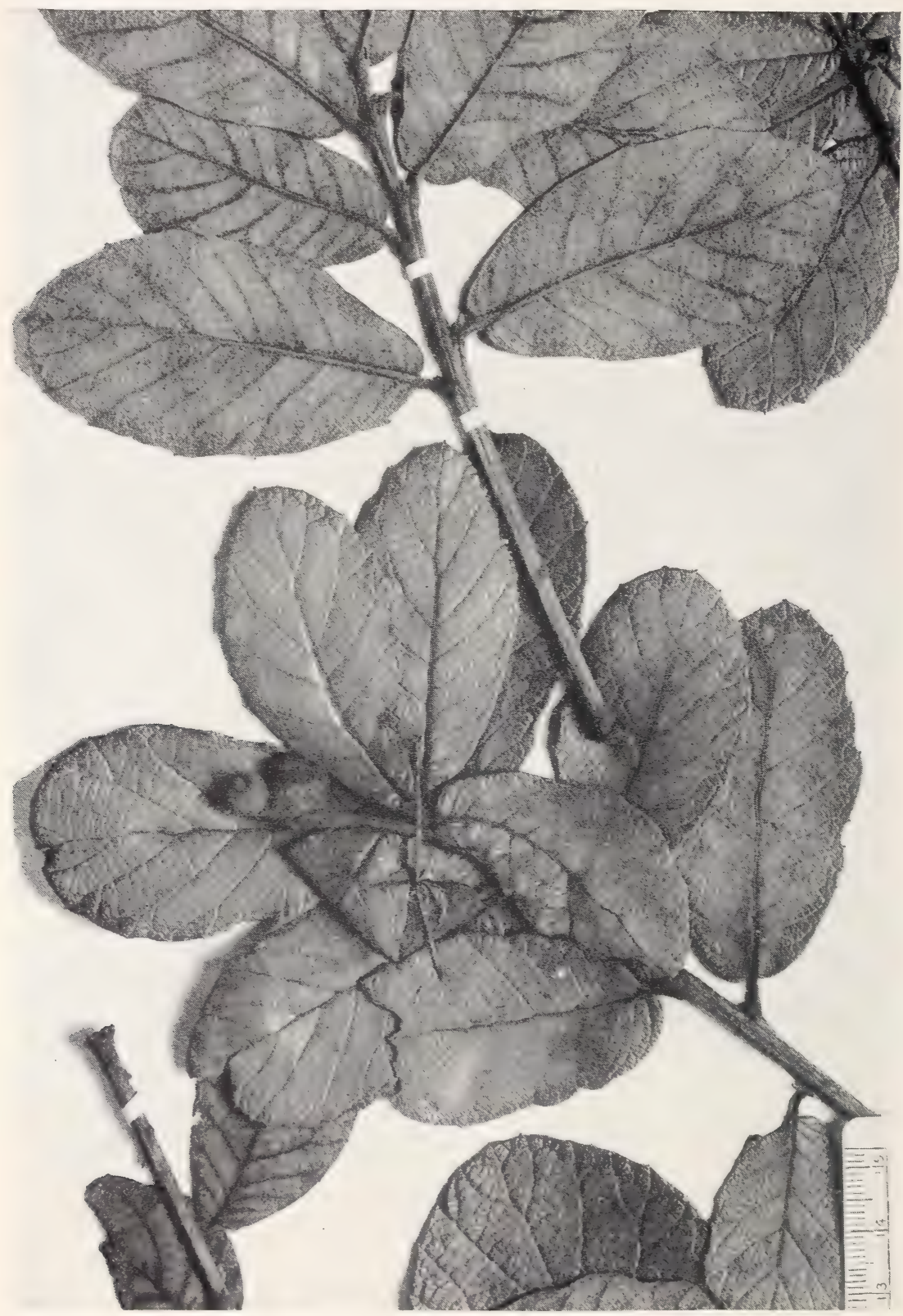

Quercus pilicaulis Trel. A variant from Guatemala (Hurter \%-Ill). 
Miscellaneous Publication 477, U. S. Dept. of Agriculture

PLATE 49

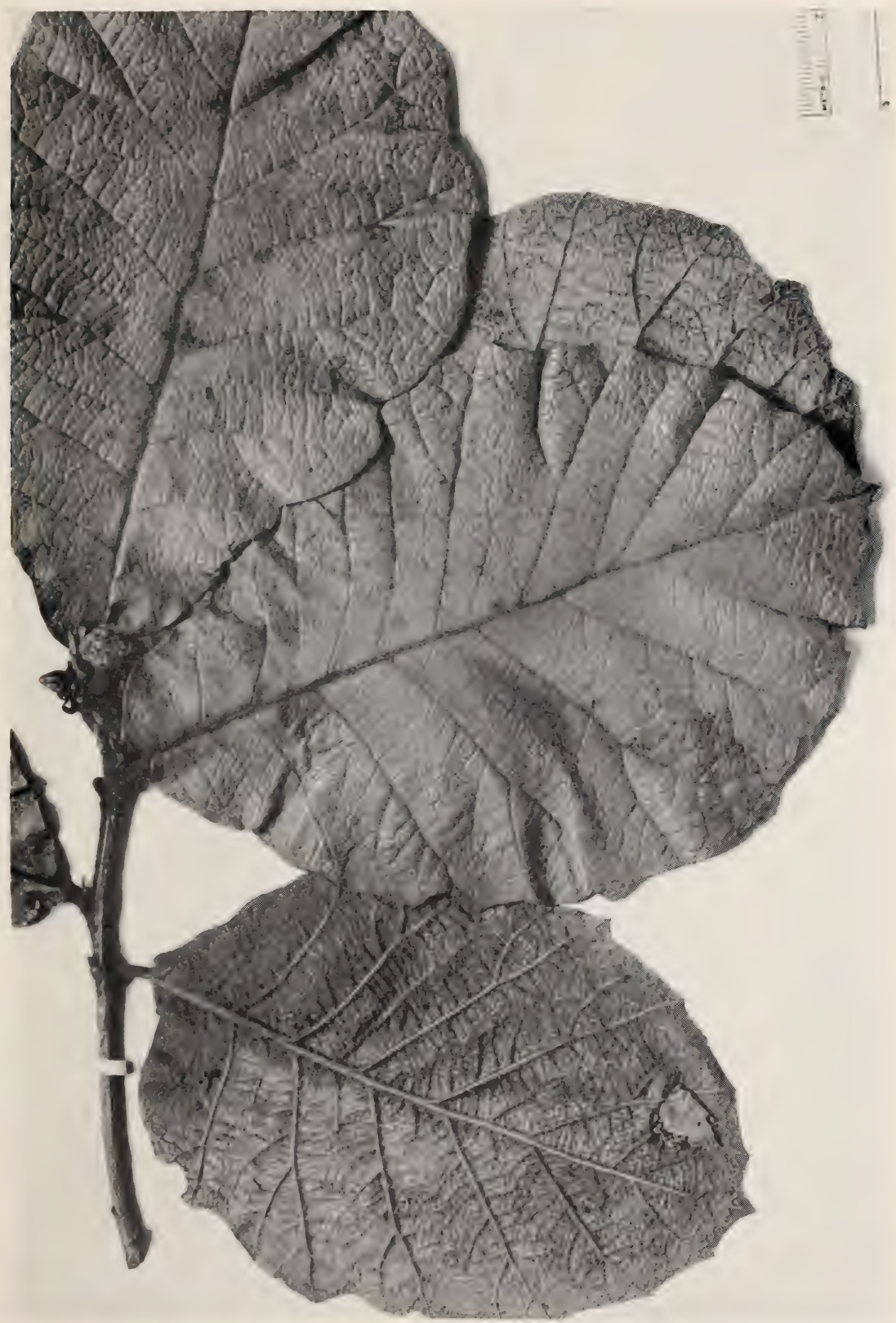

Quercus pilicaulis Trel. Type of $\mathrm{f}$. hurteri Trel., a common variant from Guatemala (Trelease 37-Ill). 


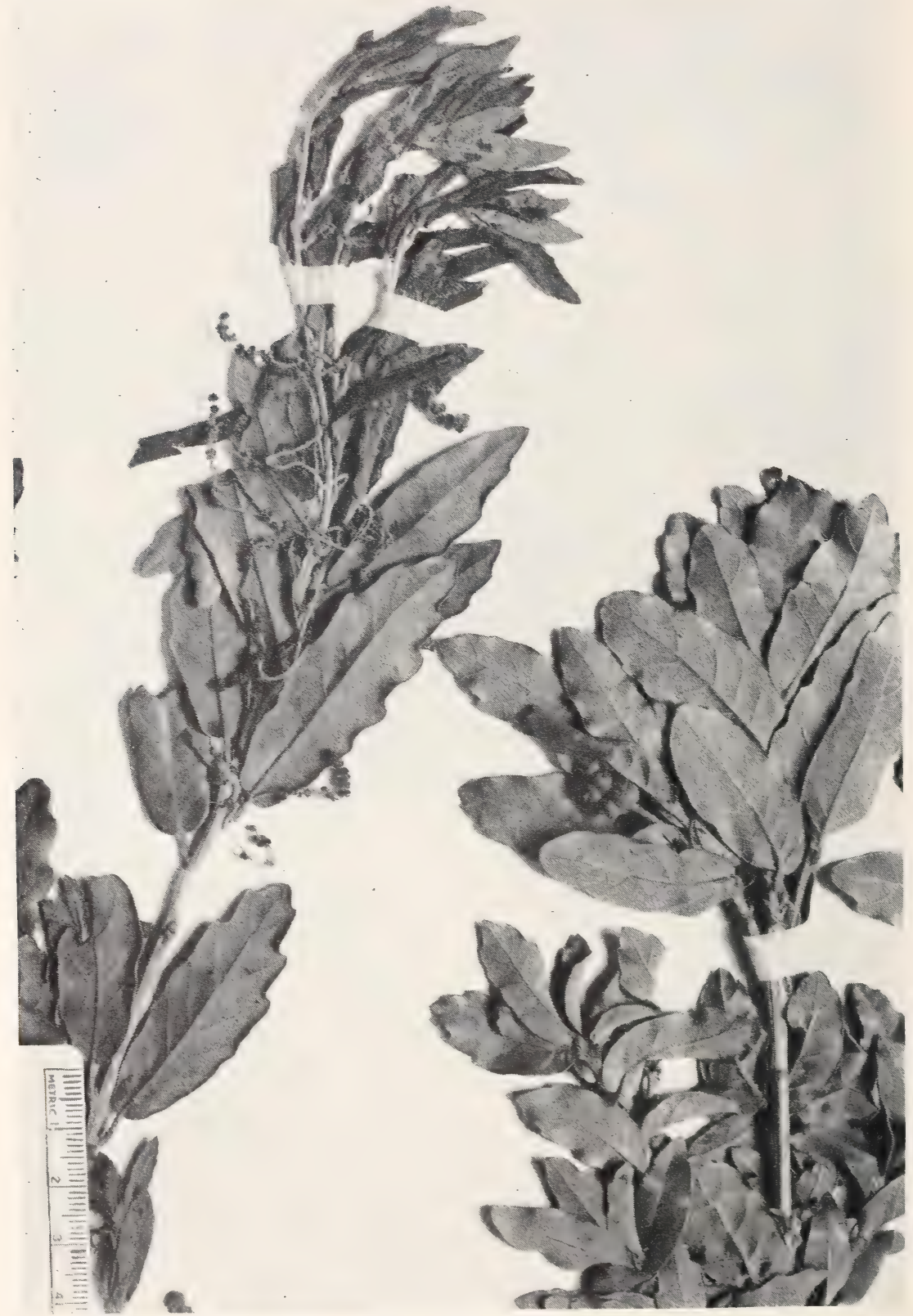

Quercus sebifera Trel. Type from Chiapas, Mexico (Cook 79-US). 


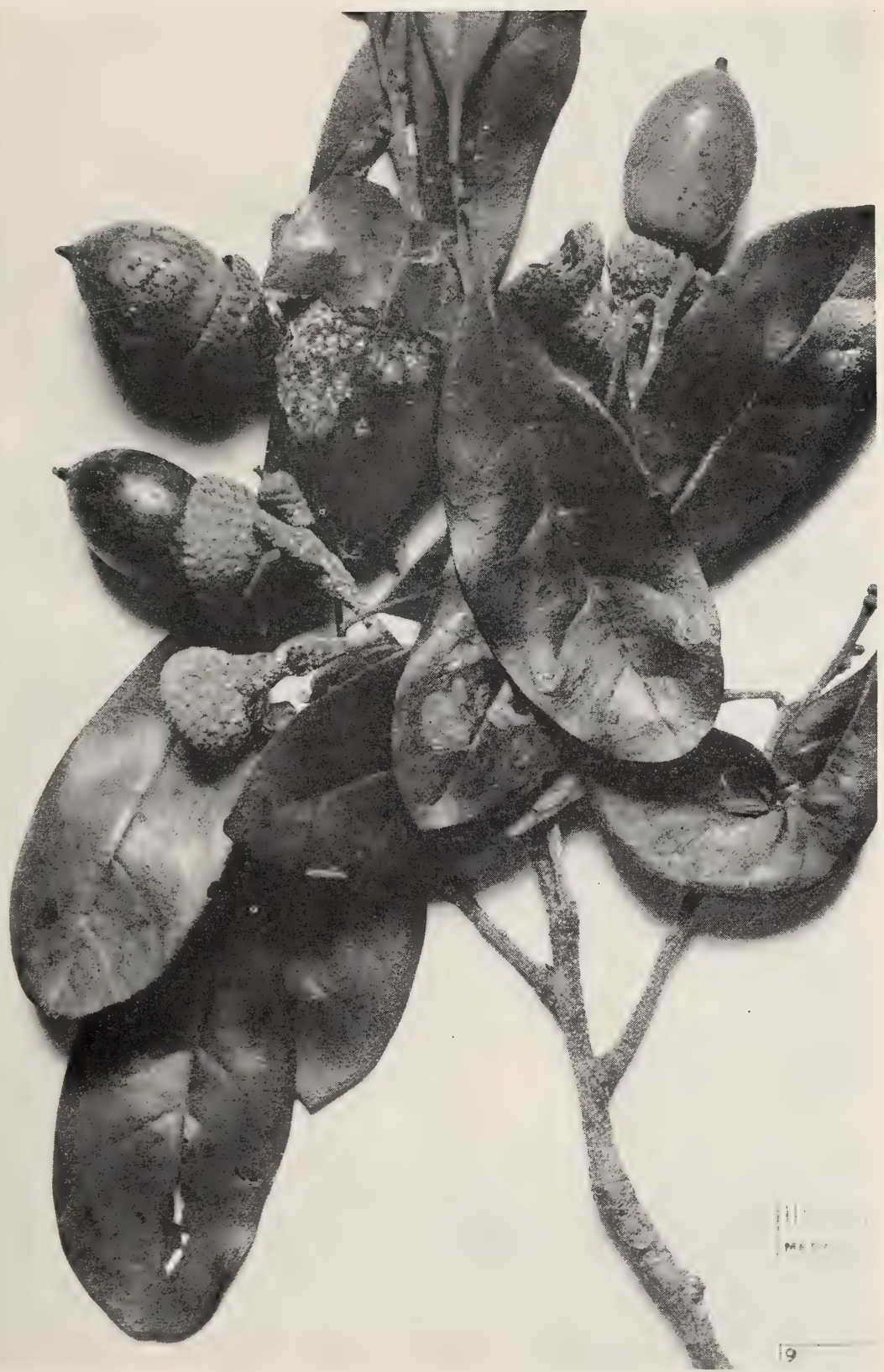

Quercus oleoides Schlecht. and Cham. A representative specimen from British Honduras (Schipp 209-AA). 
144 Misc. PUBLICATION 477 , U. S. DEPT. OF AGRICULTLRE

Miscellaneous Publication 477, U. S. Dept. of Agriculture

PLATE 52
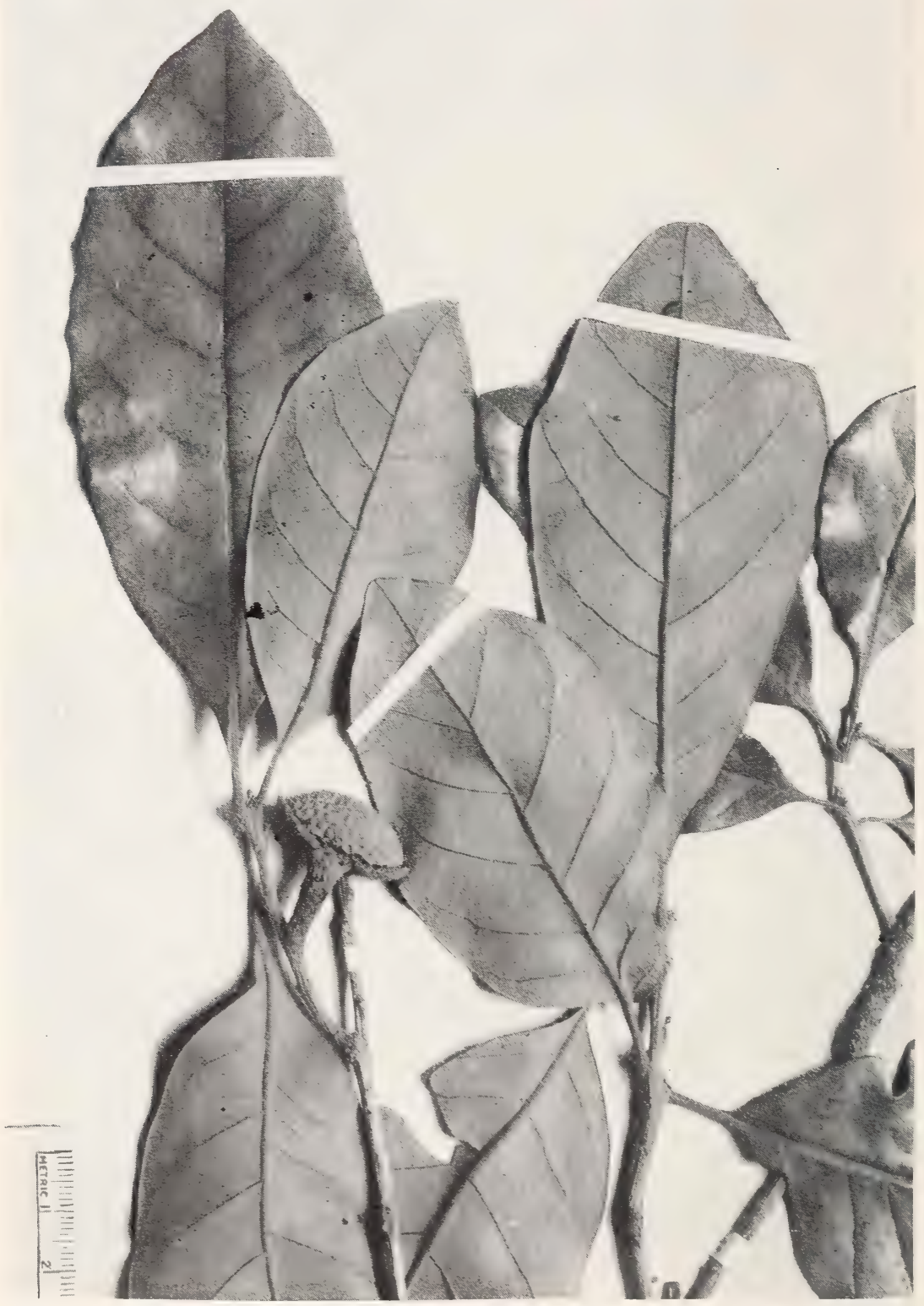

Quercus oleoides Schlecht. and Cham. A representative specimen from British Honduras (Schipp 672-AA). 




Quercus oleoides Schlecht. and Cham. A common juvenile form representative of f. lutescens (Mart. and Gal.) Trel. from Guatemala (Bartlett 12112-US). 
Miscellaneous Publication 477, U. S. Dept. of Agriculture

PLATE 54

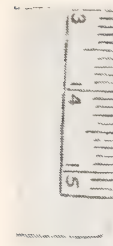

$$
\underbrace{2}
$$
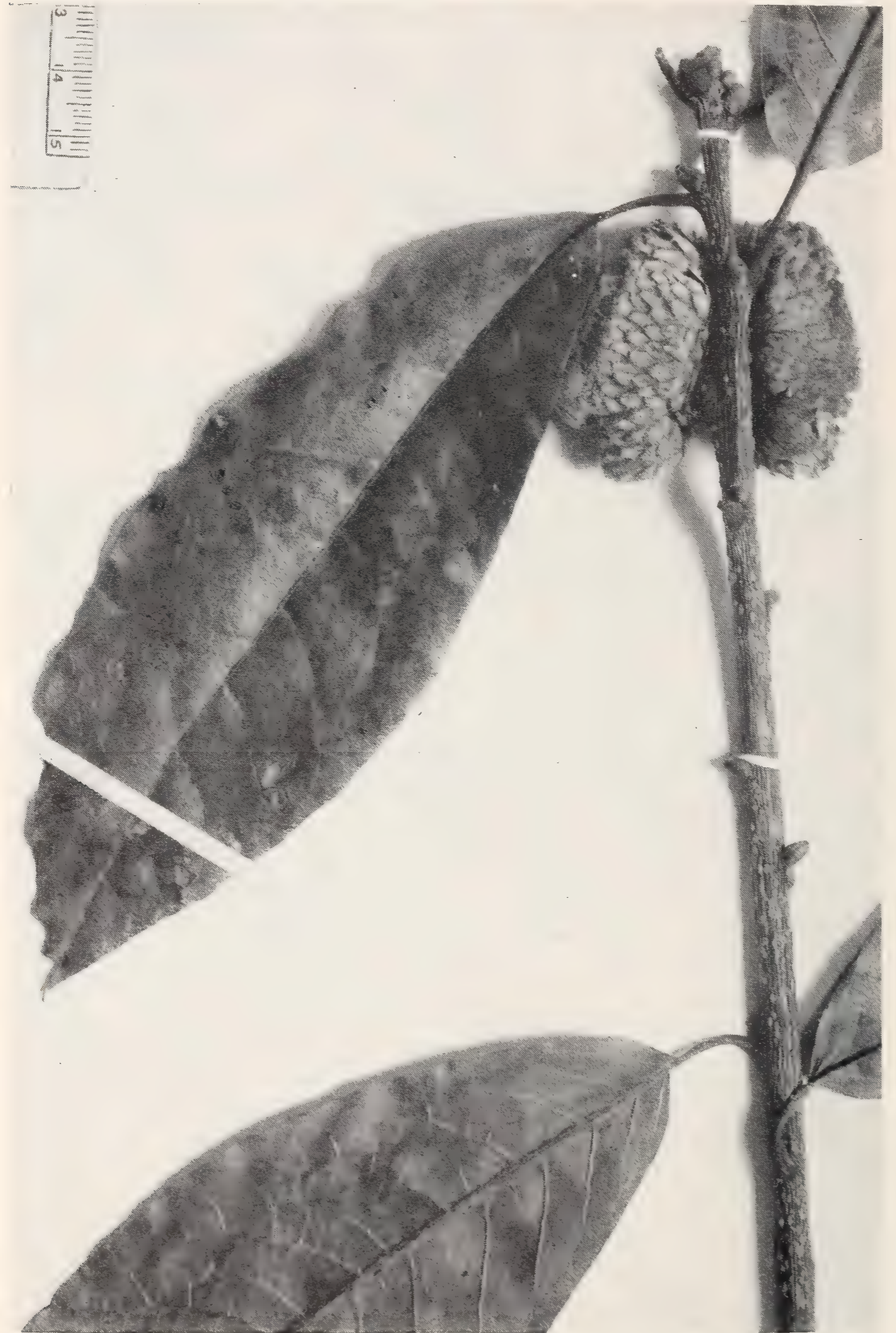

Quercus humboldtii Bonpl. A representative specimen from Colombia (Perez and Cuatrecasas 5801-US). 


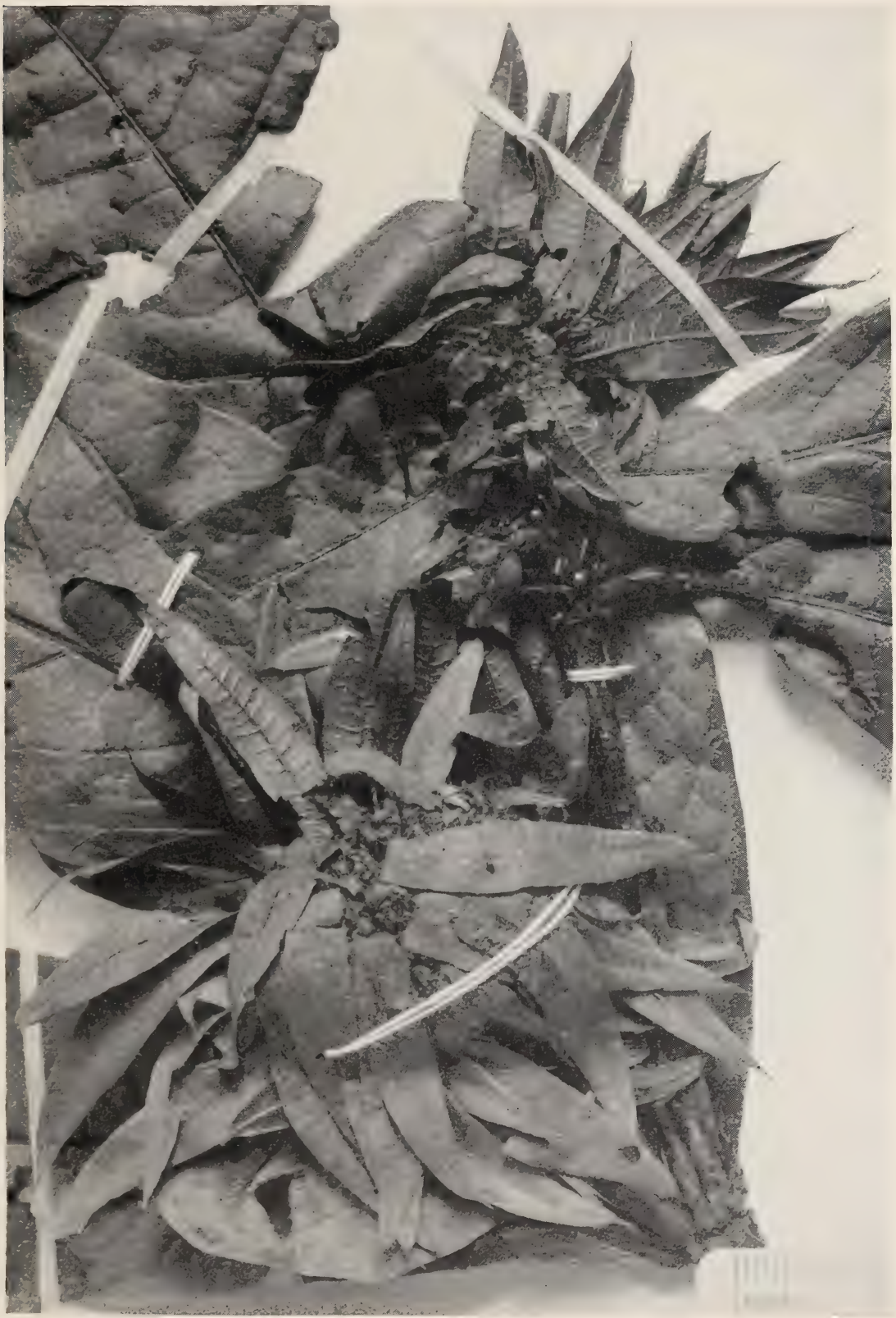

Quercus humboldtii Bonpl. A teratological fruiting specimen with foliose cup scales, each bearing in its axil a fully developed pistillate flower, from Colombia (Bro. Thomas 766 - US). 


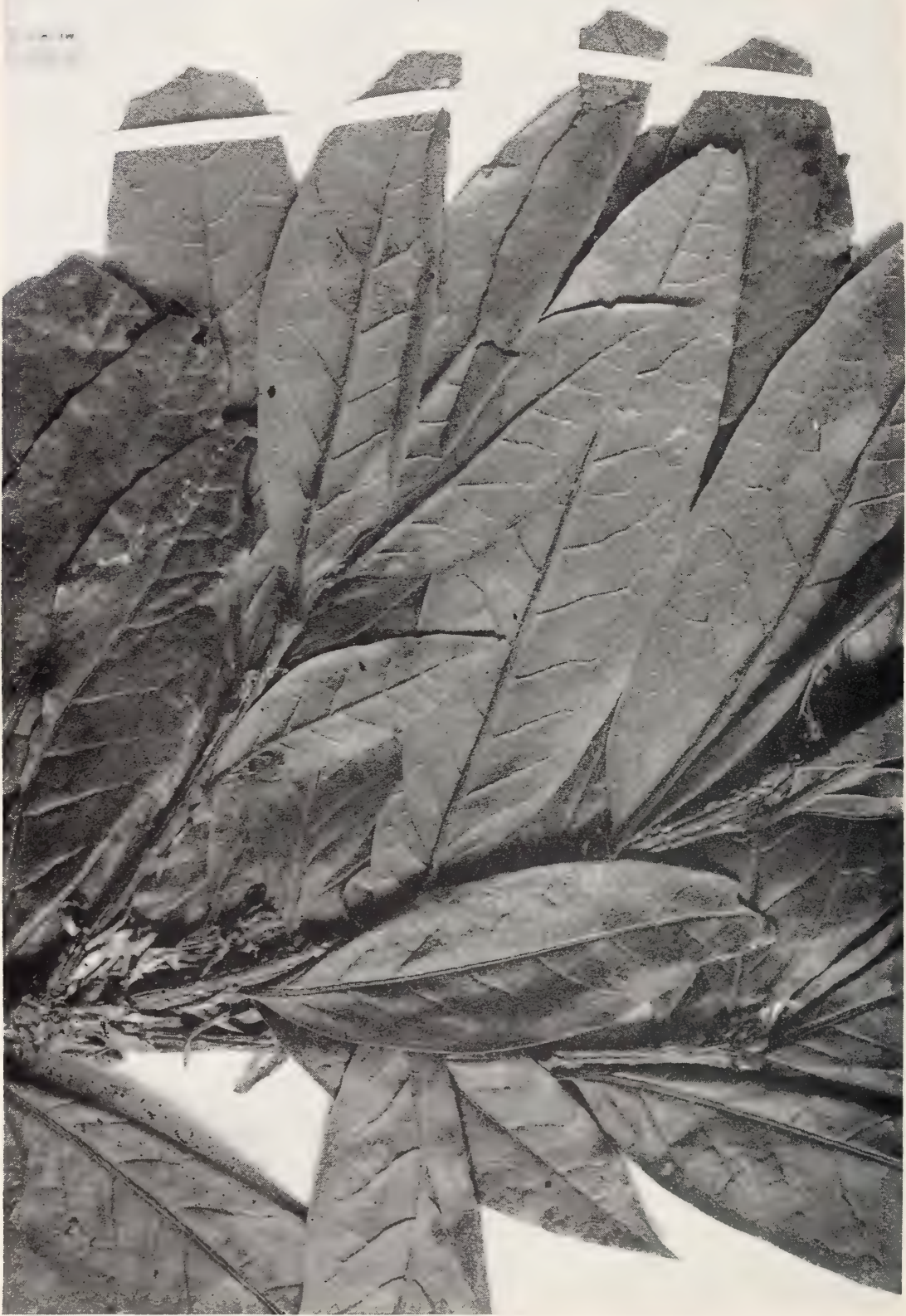

Quercus humboldtii Bonpl. A common form, isotype of Q. lindeni A. DC., from Colombia (Linden 1325-NY). 


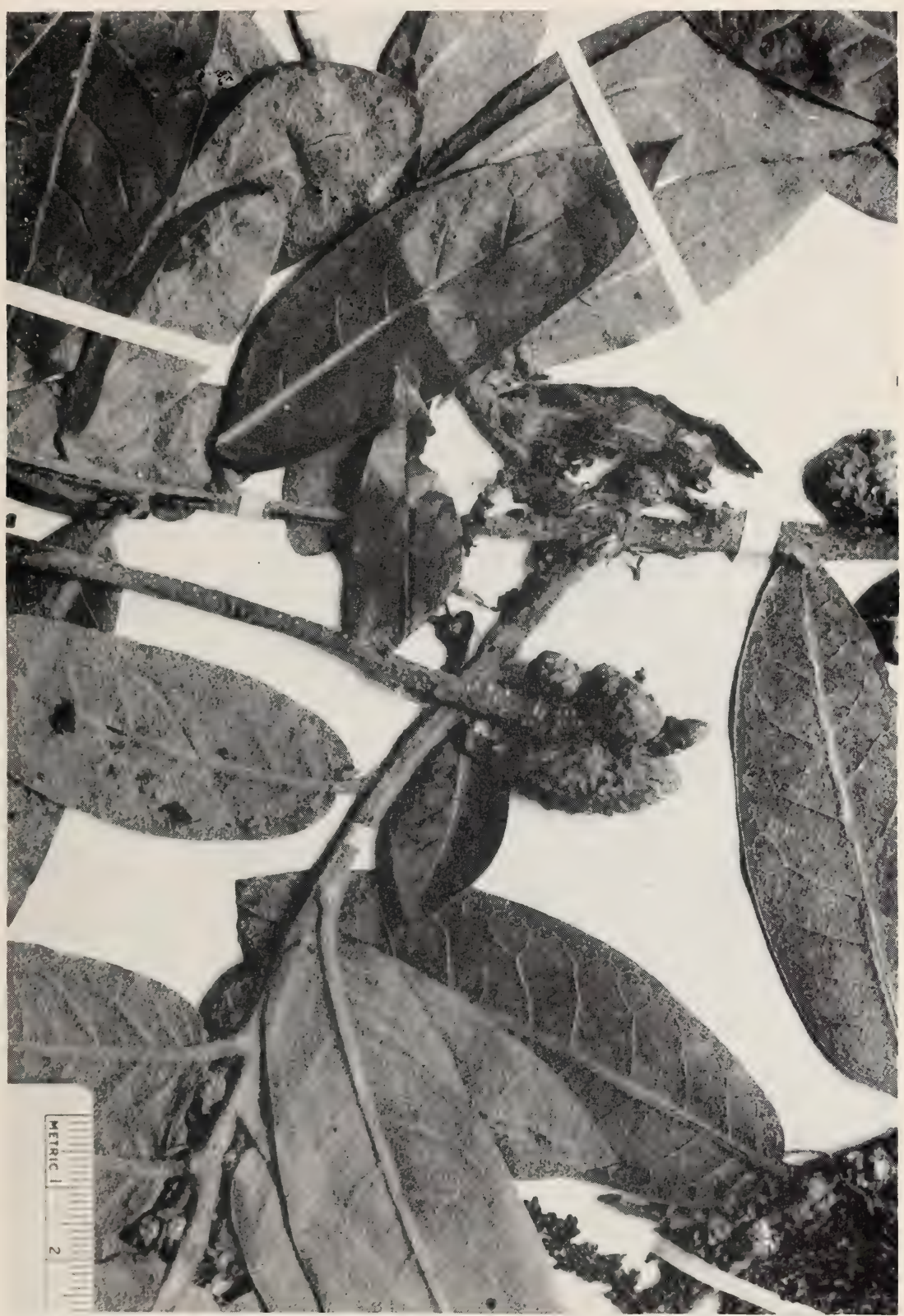

Quercus humboldtii Bonpl. A tomentose variant characteristic of the form known as Q. tolimensis Humb. and Bonpl., from Colombia (Perez and Cuatrecasas 8100 -US). 


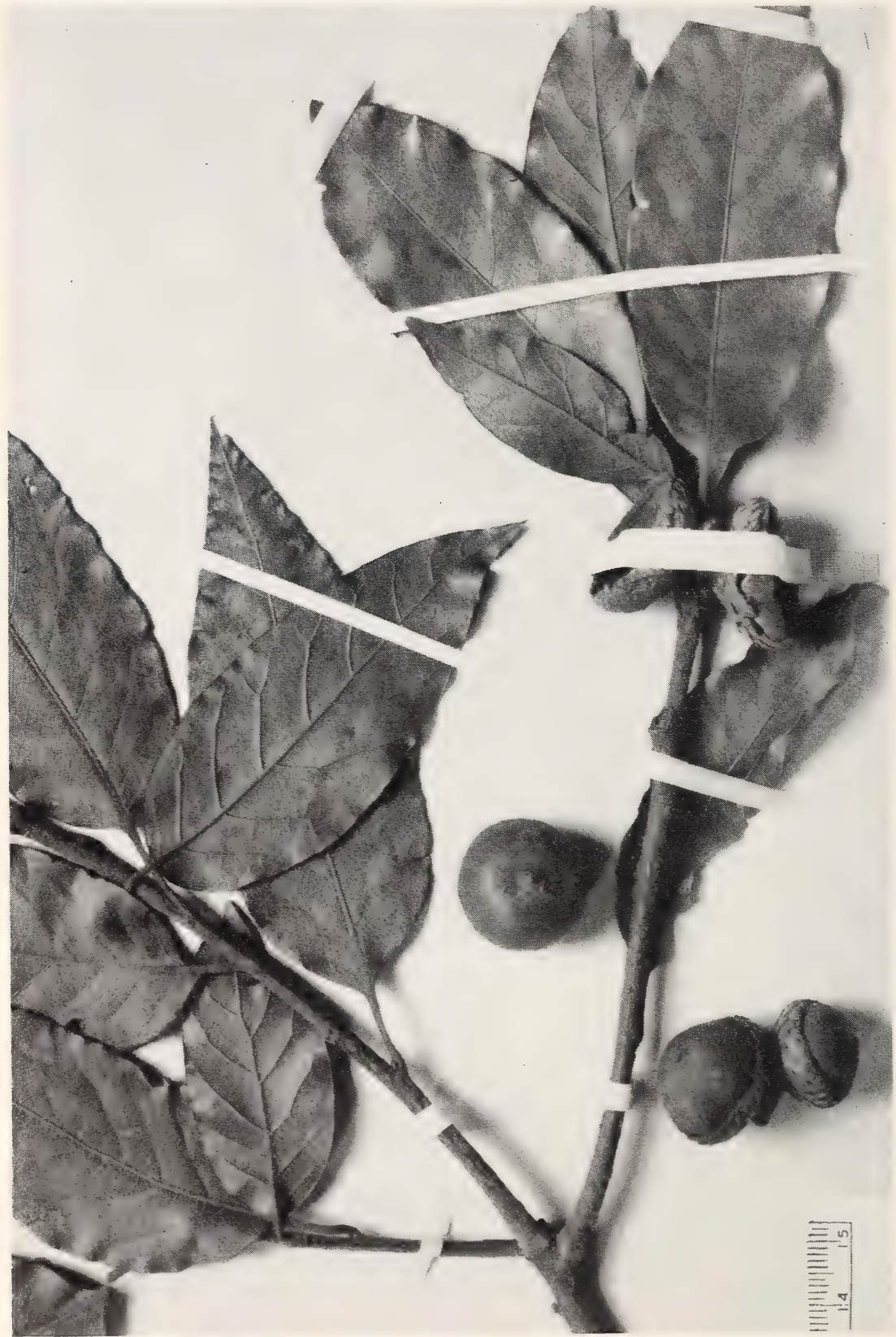

Quercus benthami A. DC. Isotype from Guatemala (Hartweg 563-NY). 


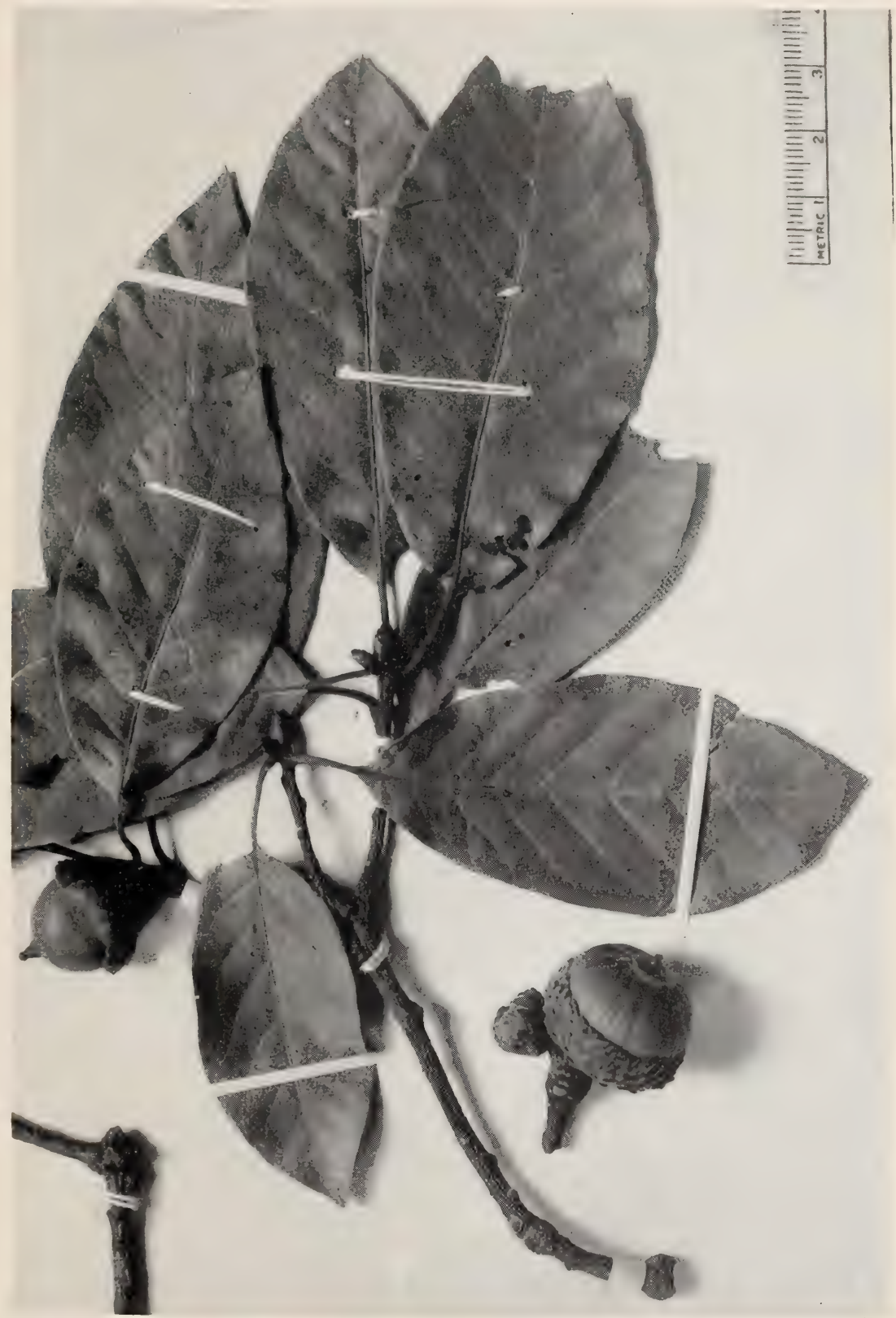

Quercus benthami A. DC. A representative specimen from Guatemala (Skutch 692-US). 




Quercus costaricensis Liebm. A representative specimen from Costa Rica (Pittier 14120 -US). 


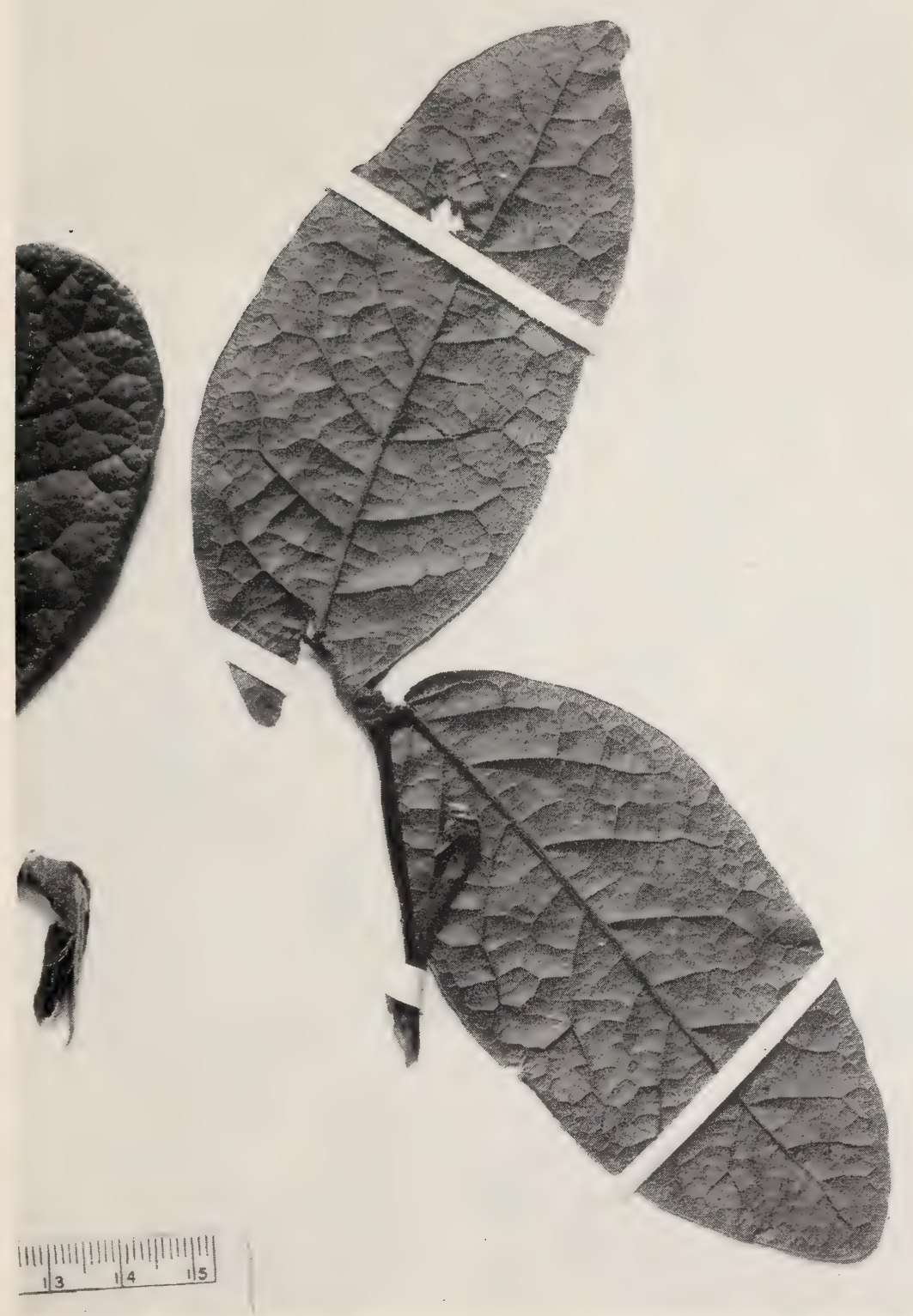

Quercus costaricensis Liebm. A variant characteristic of the synonymous Q. endresi Trel. from Costa Rica (Rowlee and Stork 940-NY). 




Quercus irazuensis Kuntze. Type from Costa Rica (Kuntze 2344-NY). 

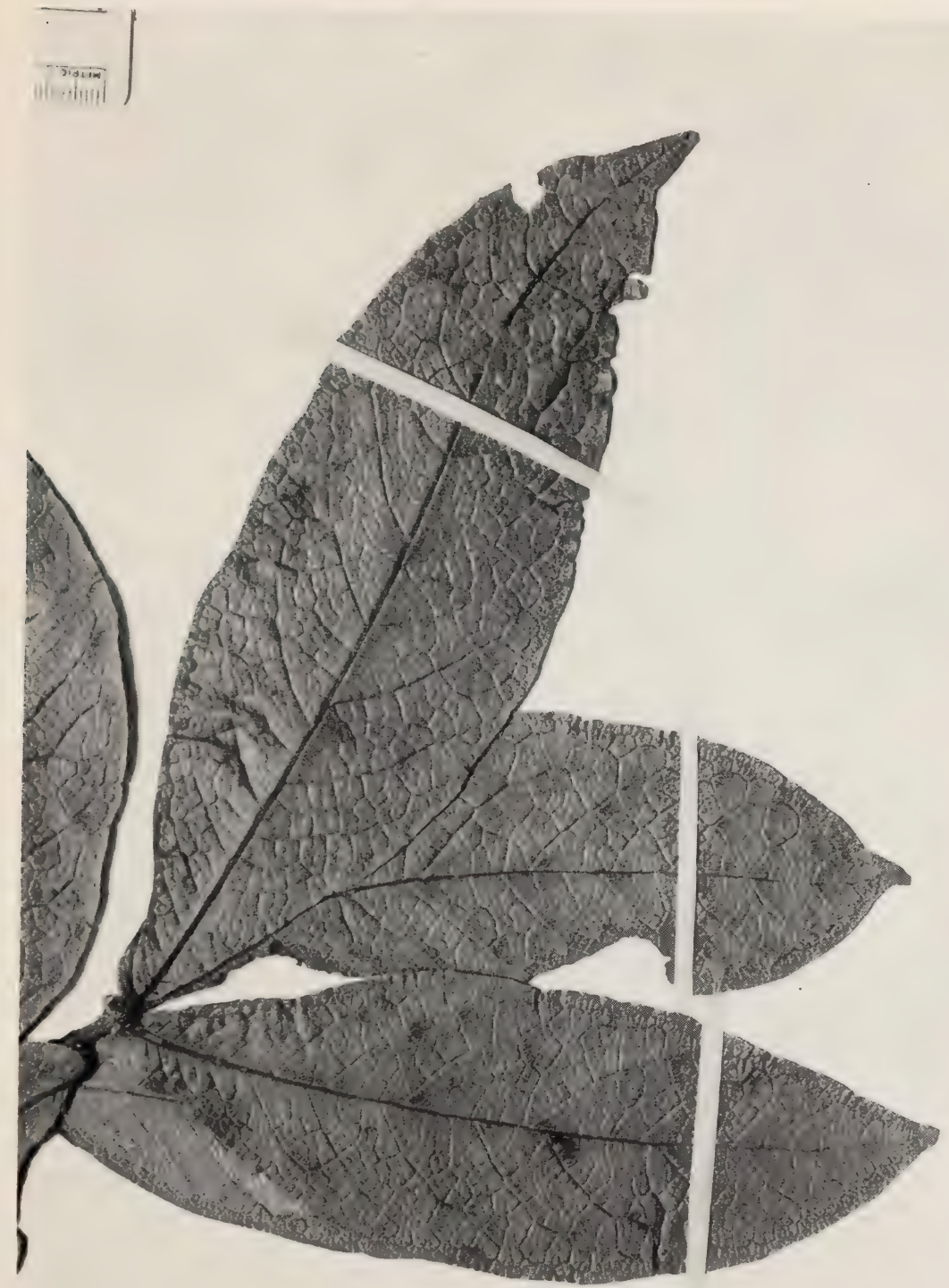

Quercus irazuensis Kuntze. A representative specimen from Costa Rica (Standley and Valerio 43752-US). 


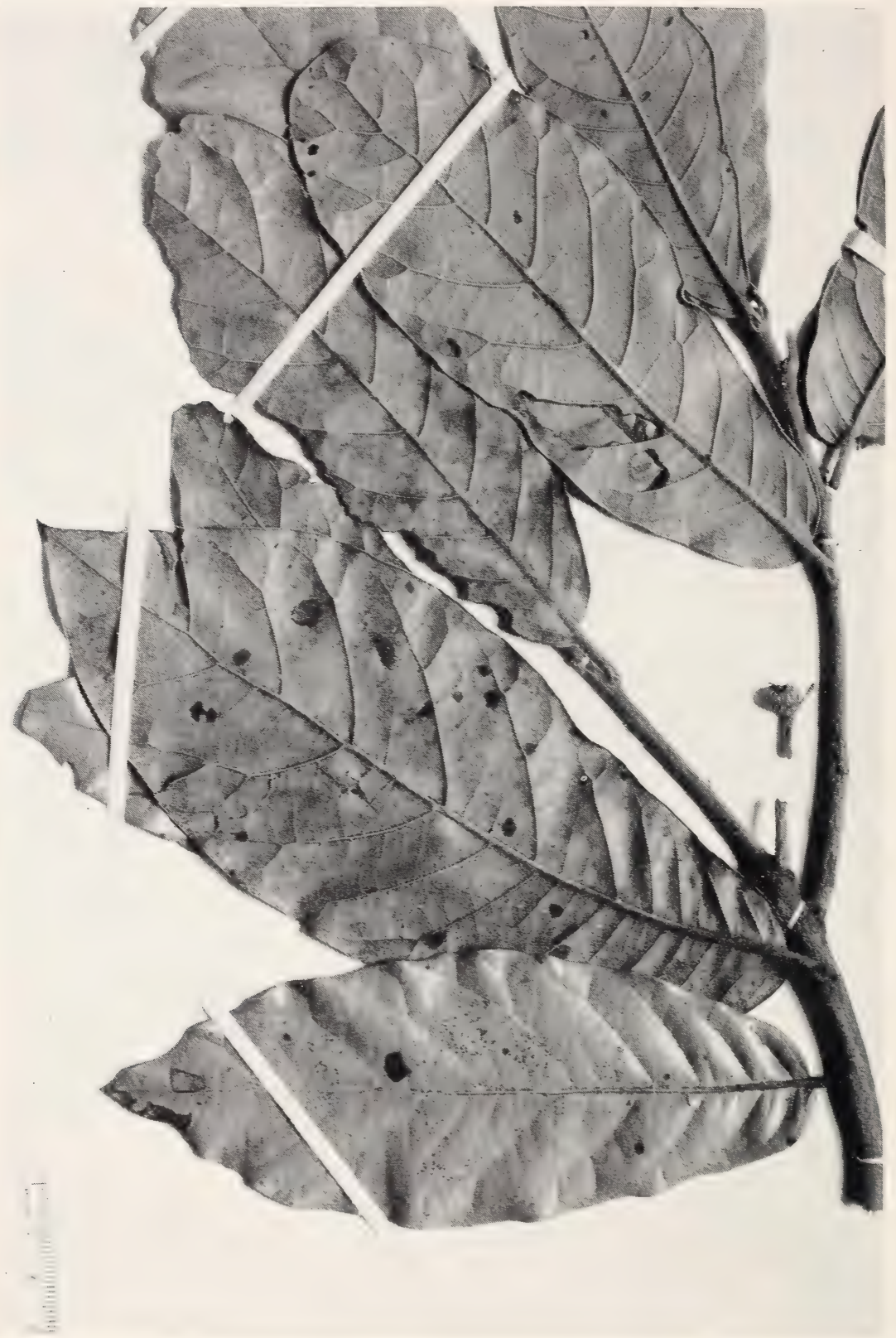

Quercus hondurensis Trel. A characteristic specimen from British Honduras (Lundell 6758-USNA). 


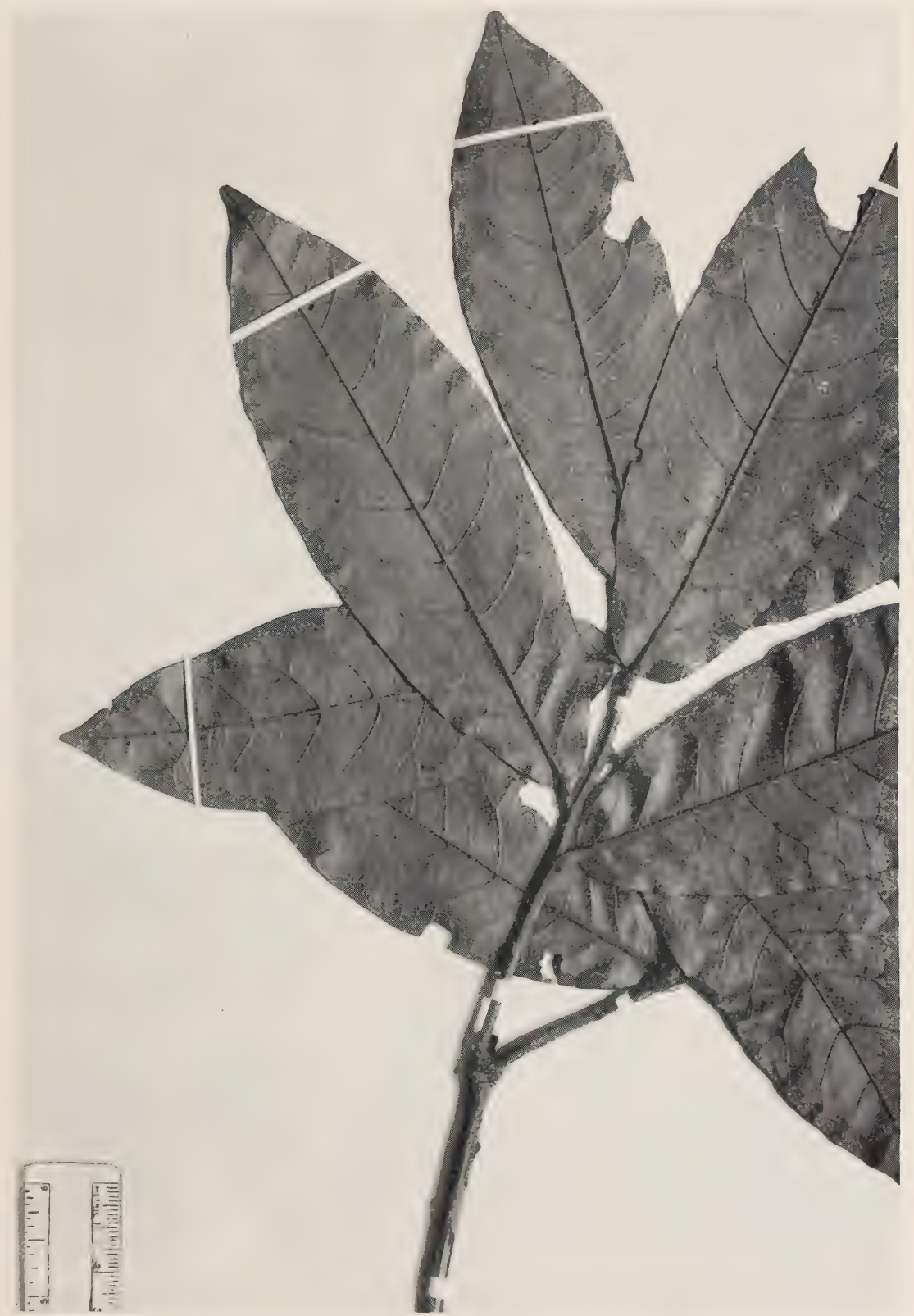

Quercus hondurensis Trel. A minor variant, isotype of Q. comayaguana Trel., from Honduras (Standley 56229-US). 
Miscellaneous Publication 477, U. S. Dept. of Agriculture

PLATE 66

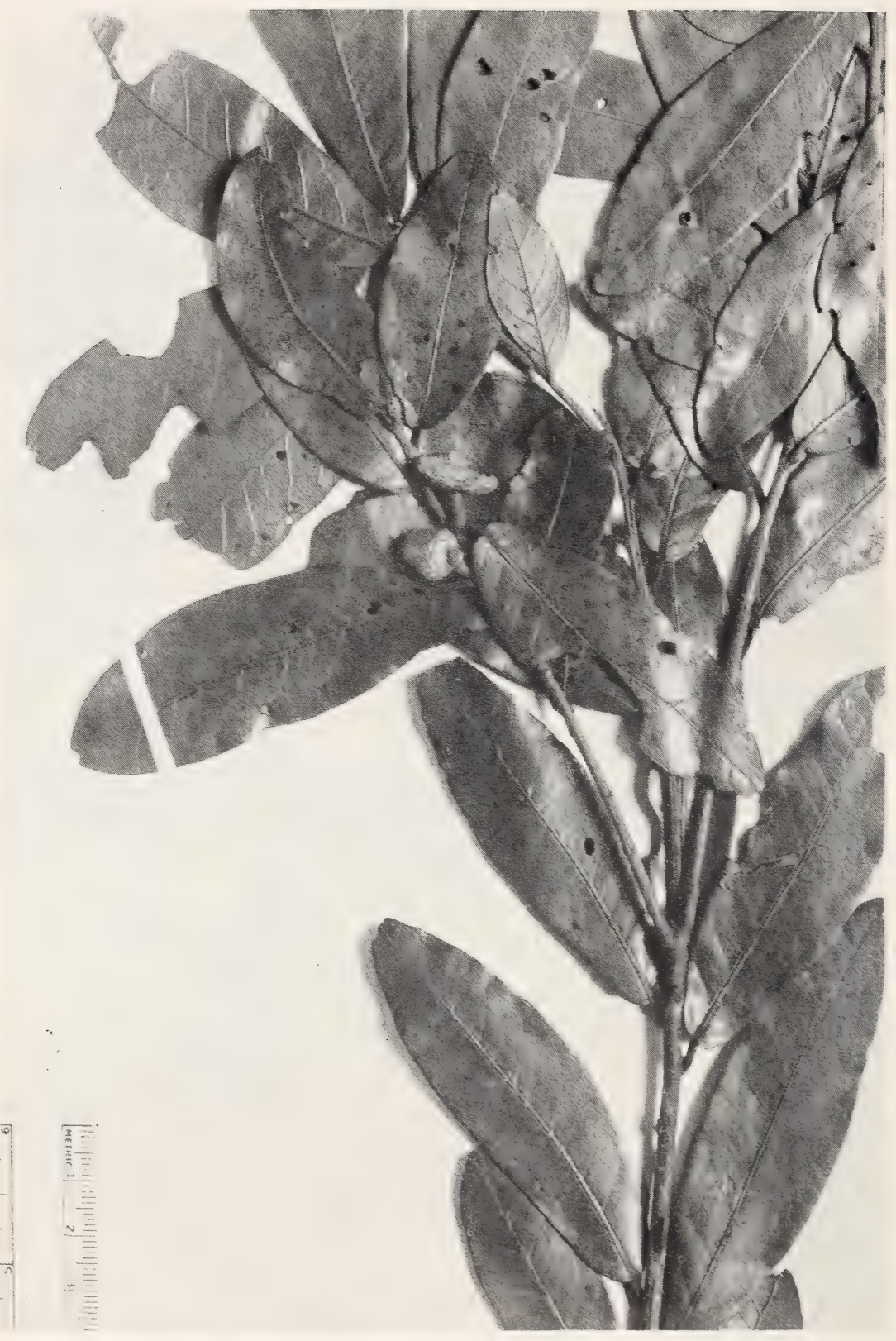

Quercus duratifolia sp. nov. Type from Chiapas, Mexico (Matuda 1827-AA). 
Miscellaneous Publication 477, U. S. Dept. of Agriculture

PLATE 67

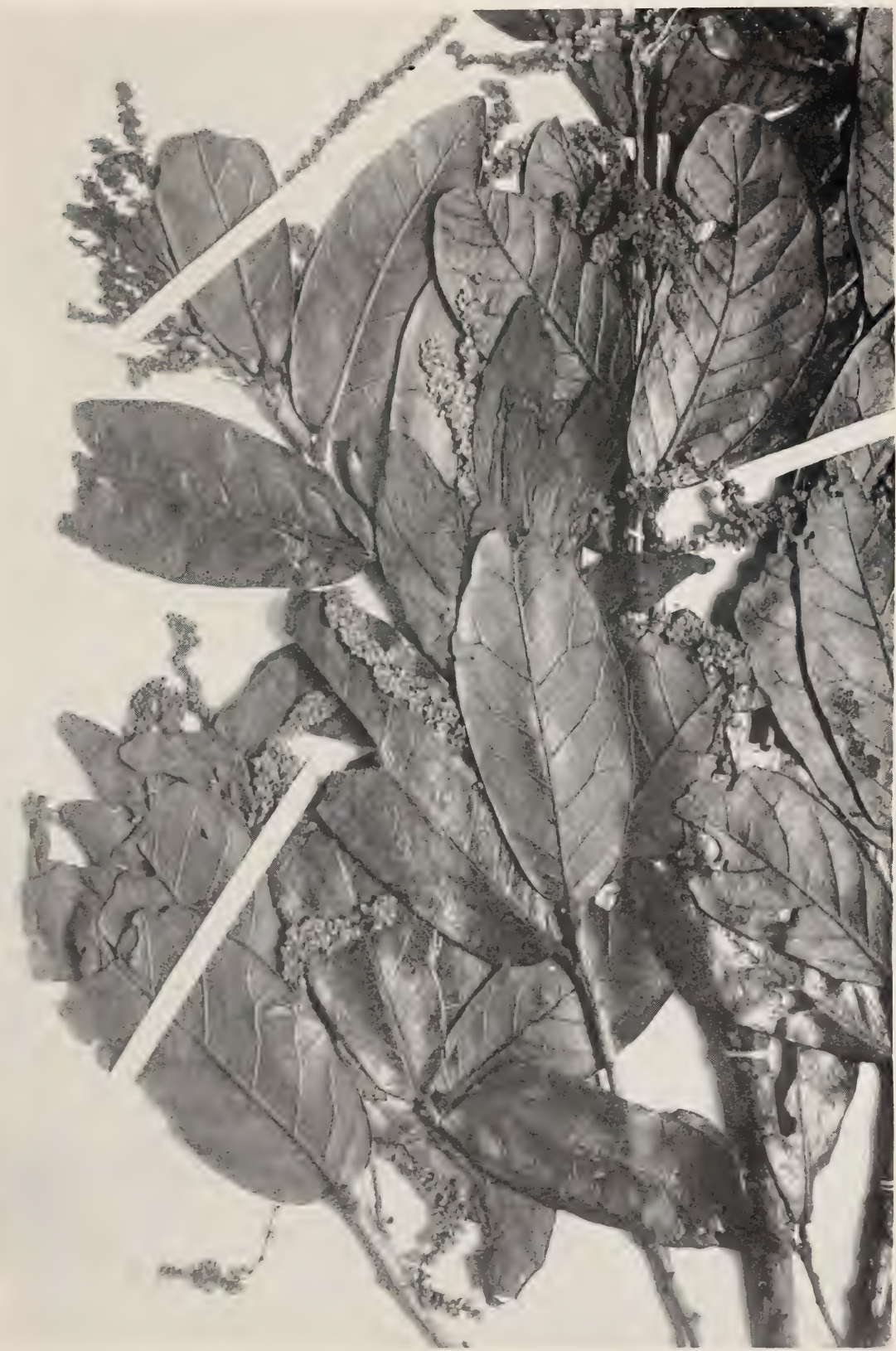

Quercus duratifolia sp. nov. A representative specimen from Chiapas, Mexico (Matuda 1873-Mi). 
Miscellaneous Publication 477, U. S. Dept. of Agriculture

PLATE 68

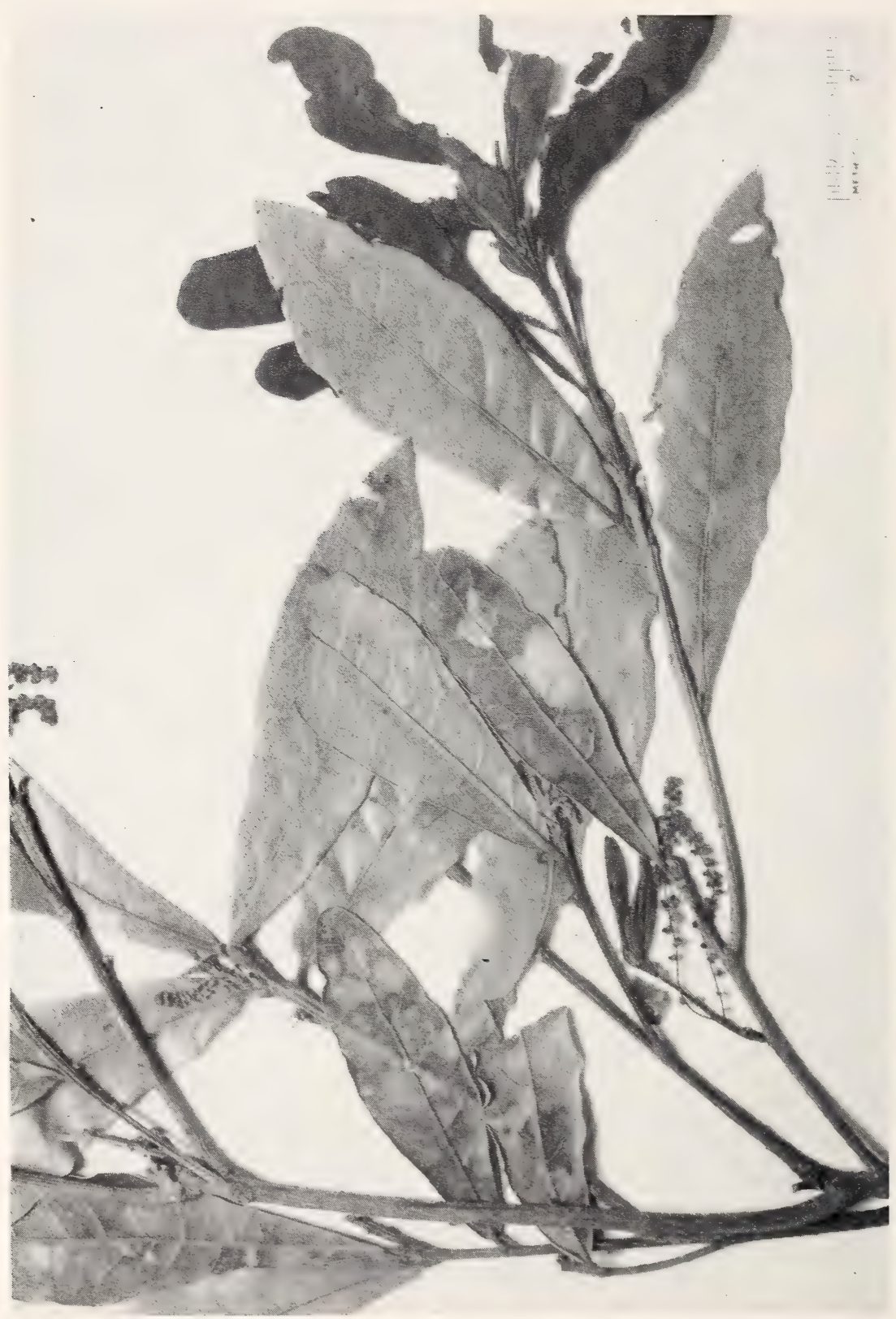

Quercus sapotaefolia Liebm. A common form from Guatemala (Smith 196\%-G). 


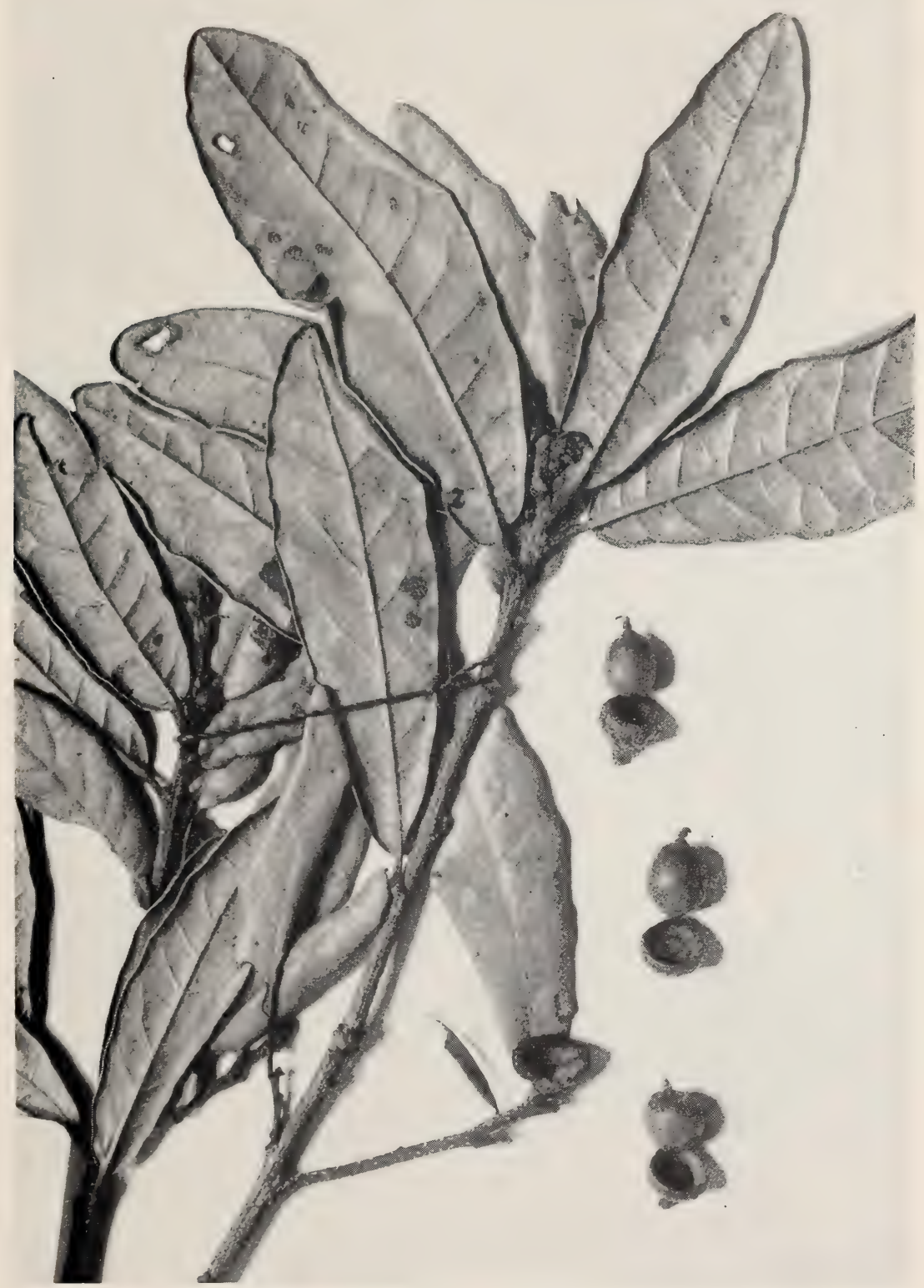

Quercus sapolaefolia Liebm. A characteristic form from Guatemala (Skutch 1906IIl). 
Miscellaneous Publication 477, U. S. Dept. of Agriculture

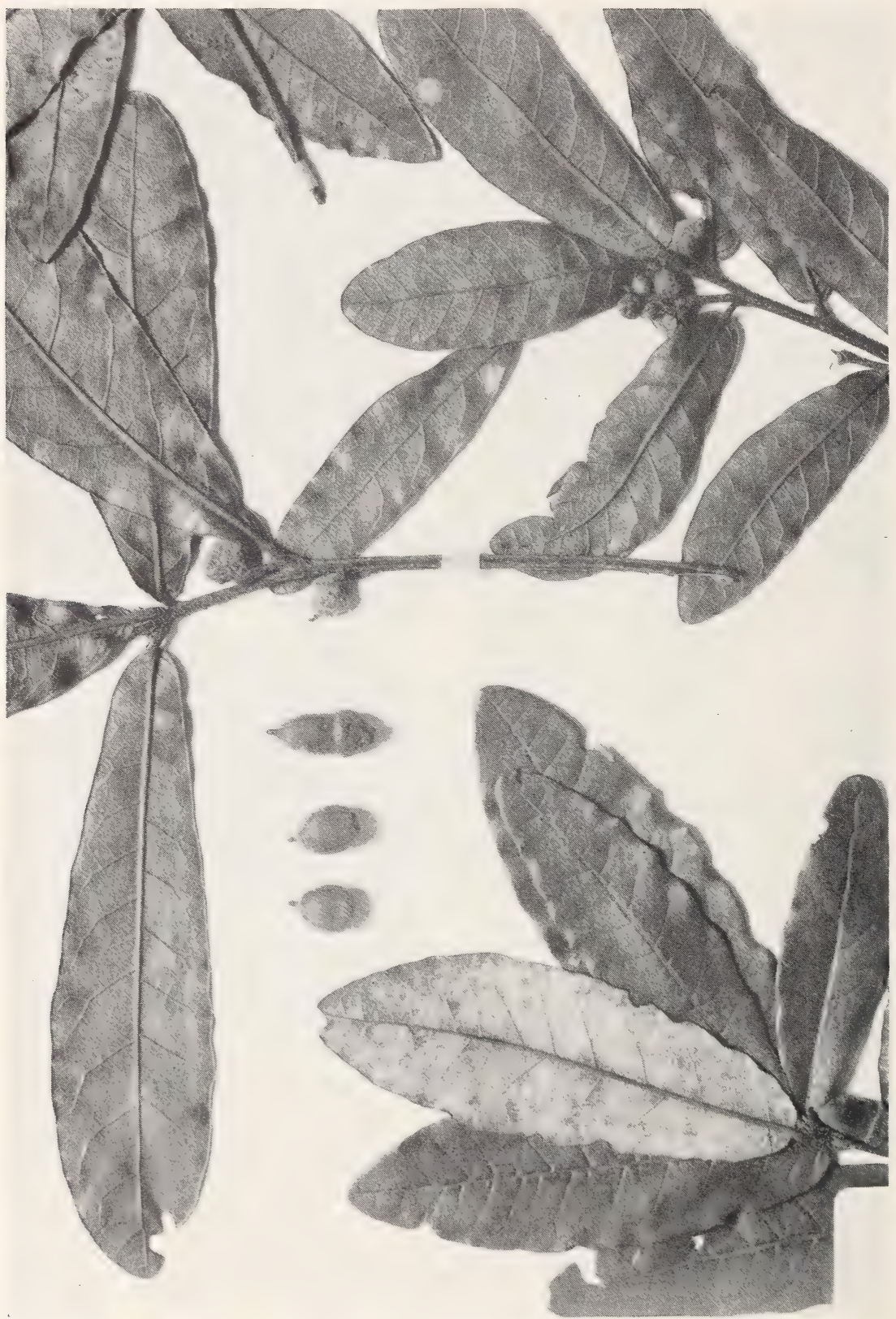

Quercus sapotaefolia Liebm. A representative specimen from Guatemala (Hayes July 1860-G). 


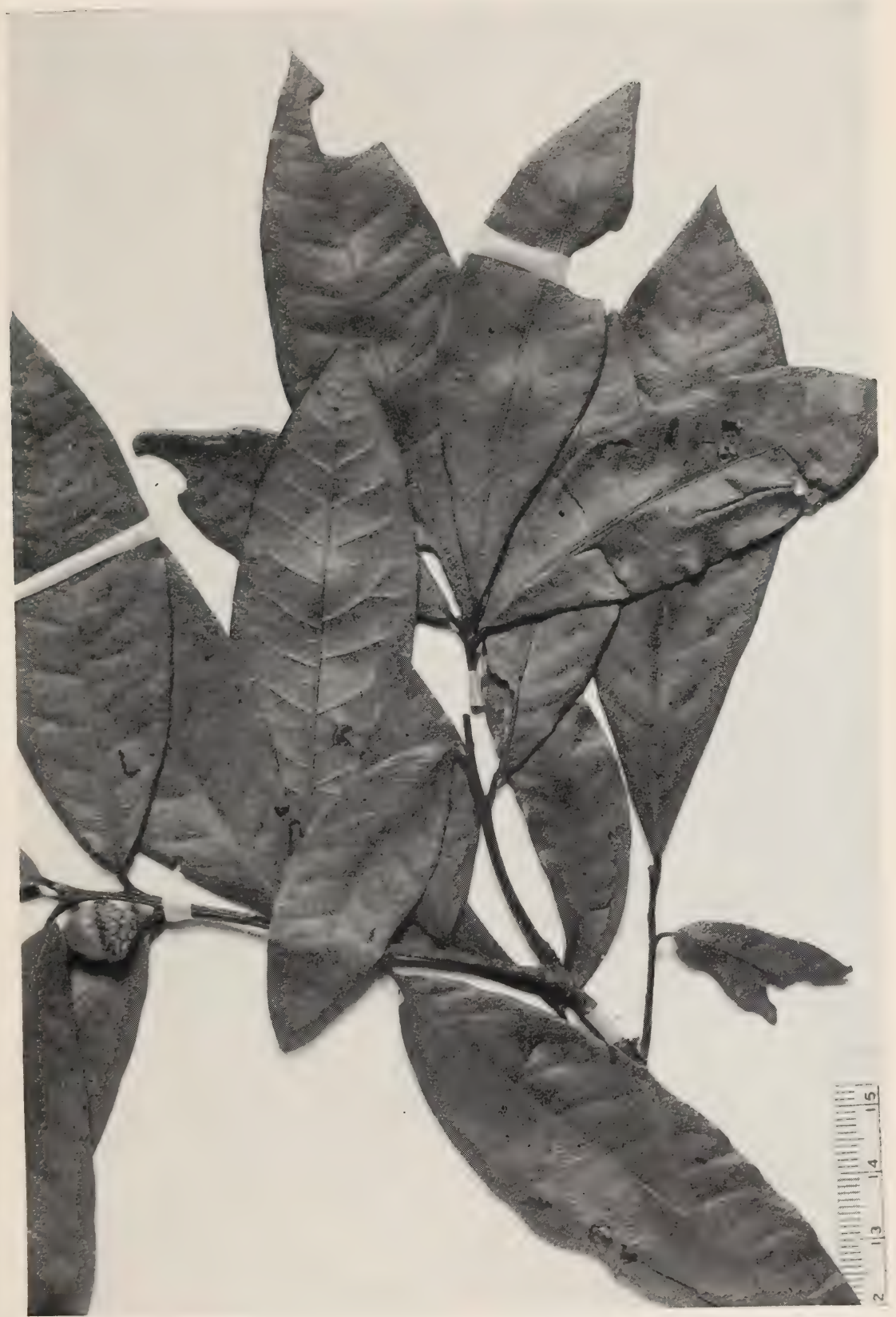

Quercus eugeniaefolia Liebm. A representative specimen from Costa Rica (Tonduz 7871-US). 


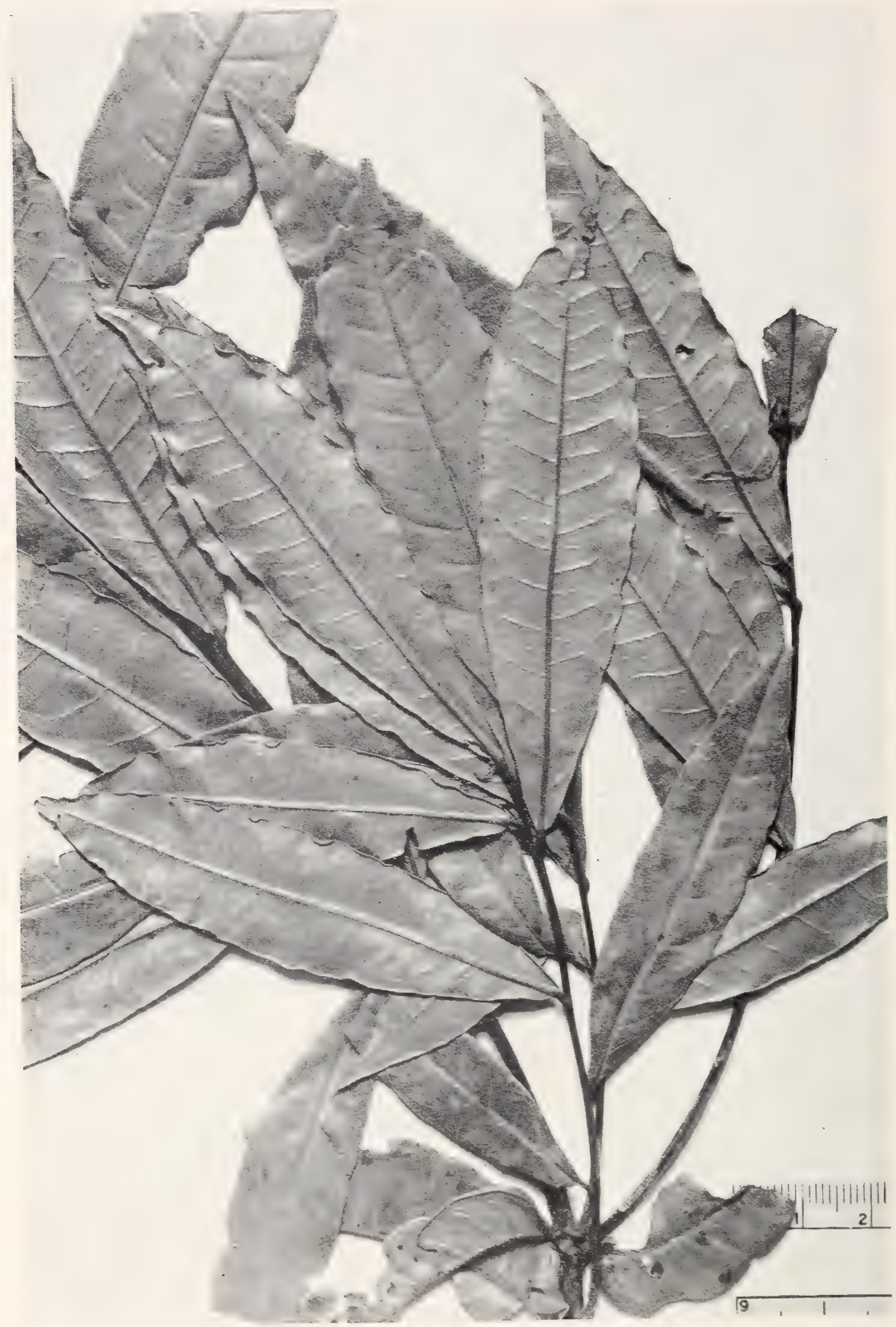

Quercus eugeniaejolia Liebm. A common form from Costa Rica (Stork 1130-F). 
Miscellaneous Publication 477, U. S. Dept. of Agriculture

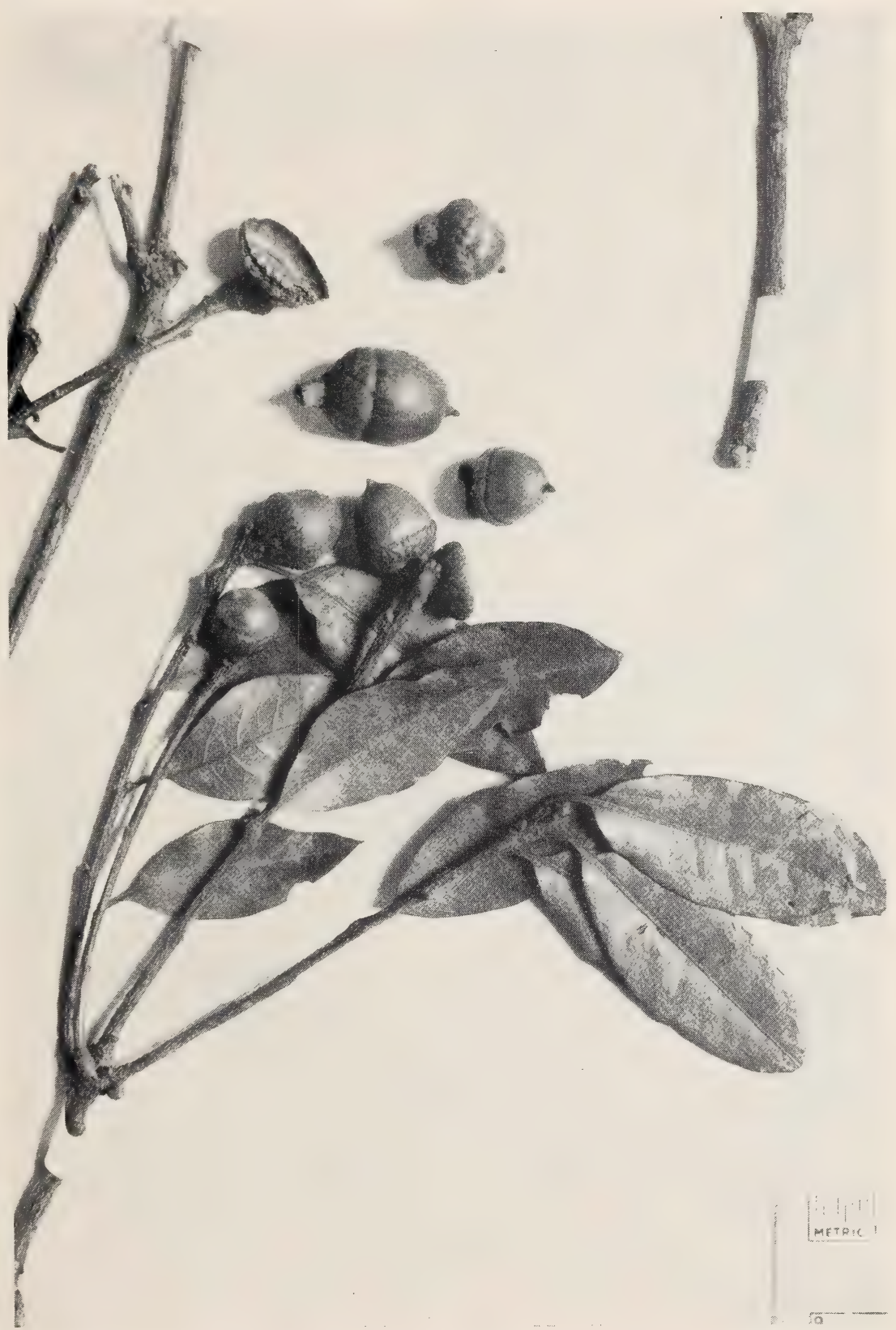

Quercus borucasana Trel. A representative specimen from Costa Rica (Tonduz $11827-U S)$. 
166 MisC. PUBLICATION 477, U. S. DEPT. OF AGRICULTURE

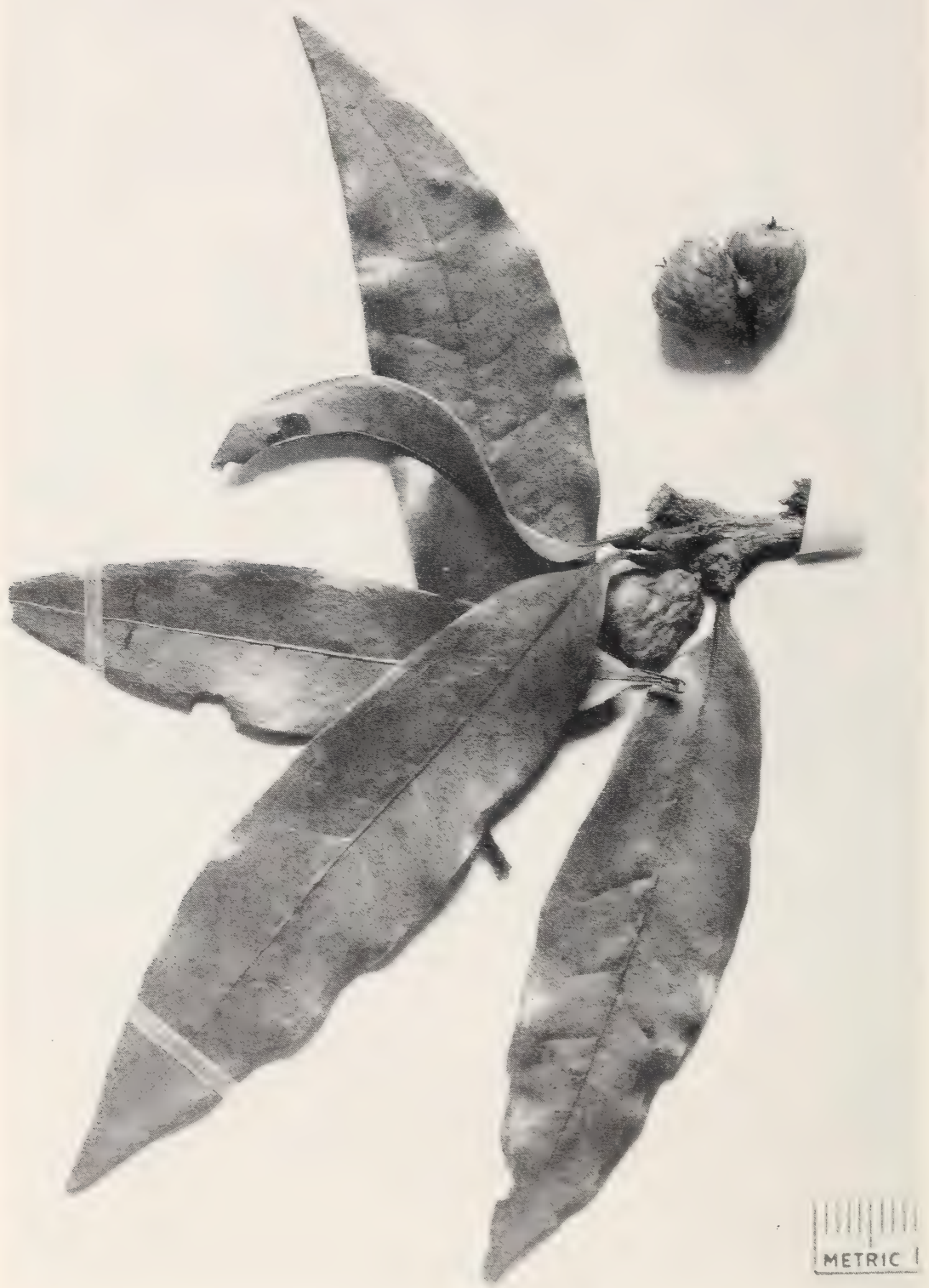

Quercus borucasana Trel. A variant from Costa Rica (Pittier 10553-CS) 


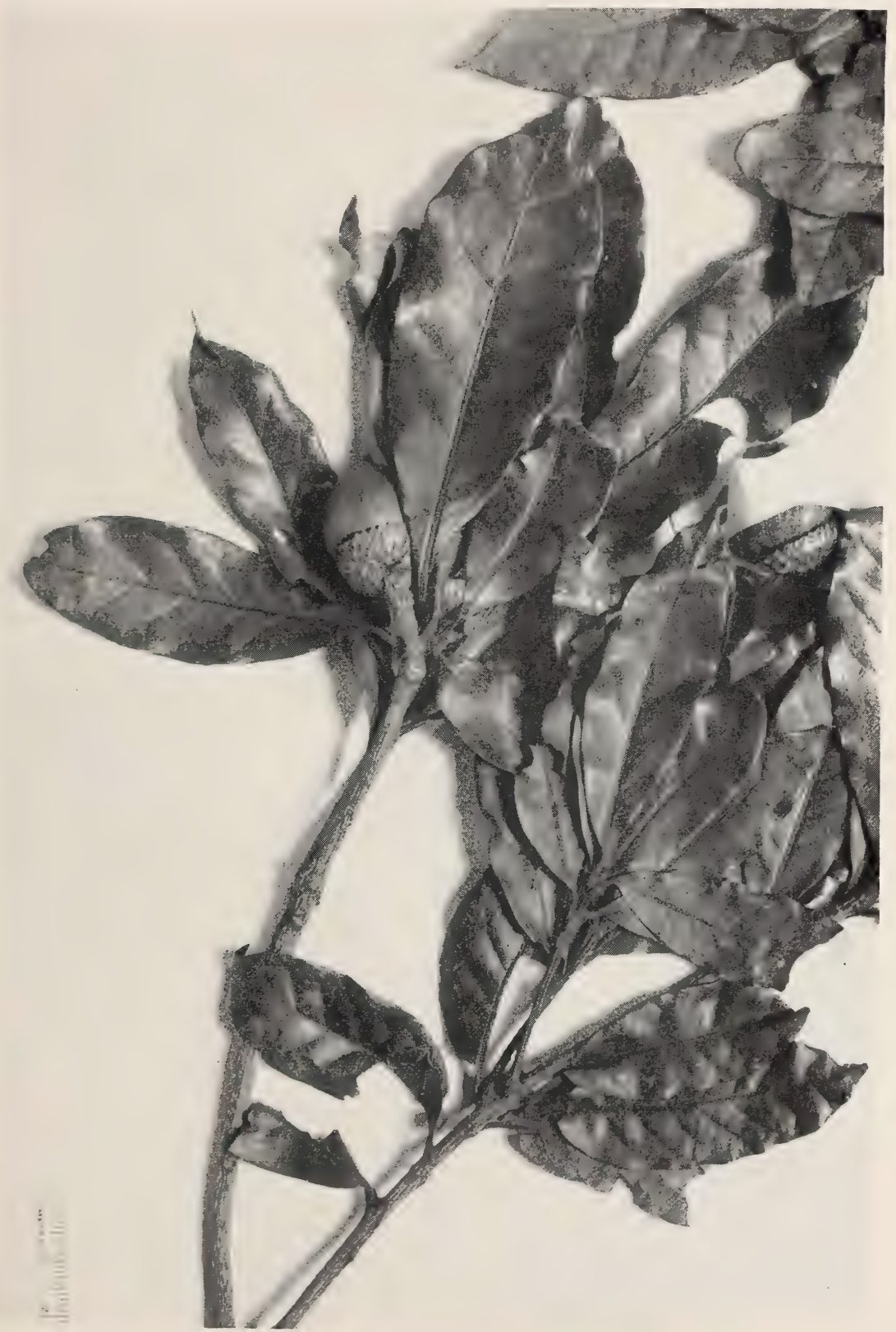

Quercus tonduzii Seemen. Isotype from Costa Rica (Tonduz 10788-US). 


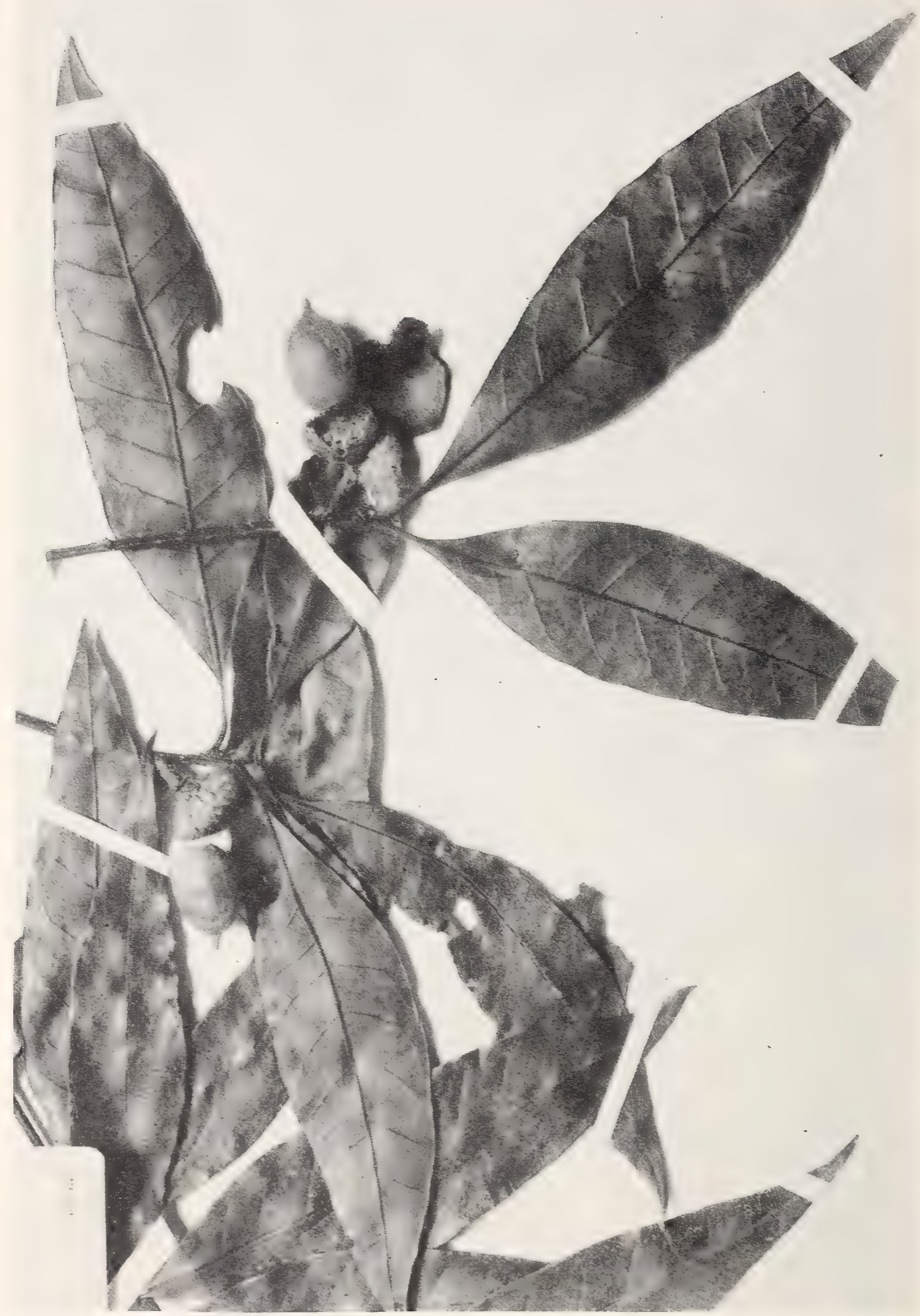

Quercus seemanni Liebm. A representative specimen from Panama (Davidson $909-F)$. 


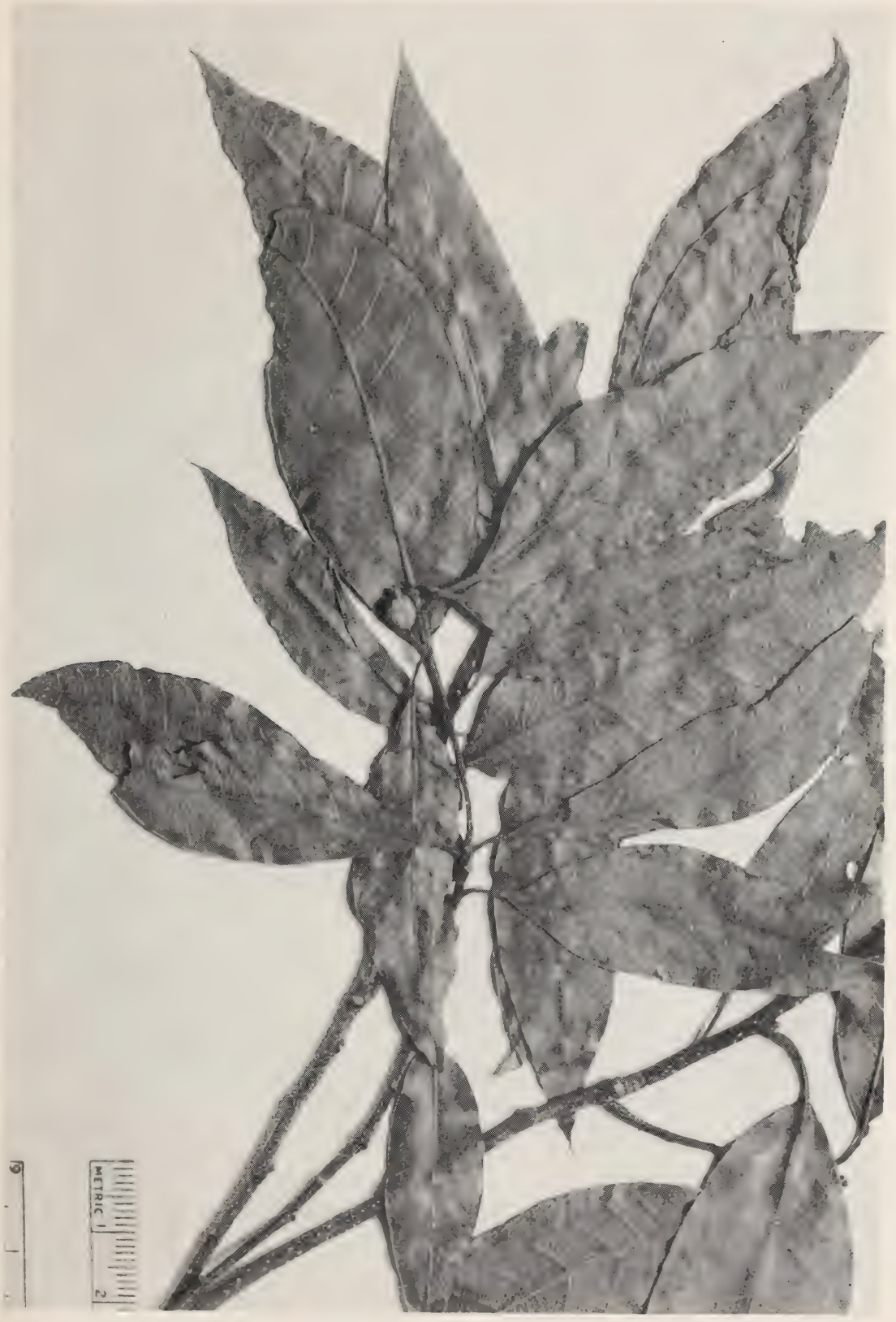

Quercus seemanni Liebm. Isotype from Panama (Seeman without number-G). 
170 MISC. PUBLICATION 477 , U. S. DEPT. OF AGRICULTURE

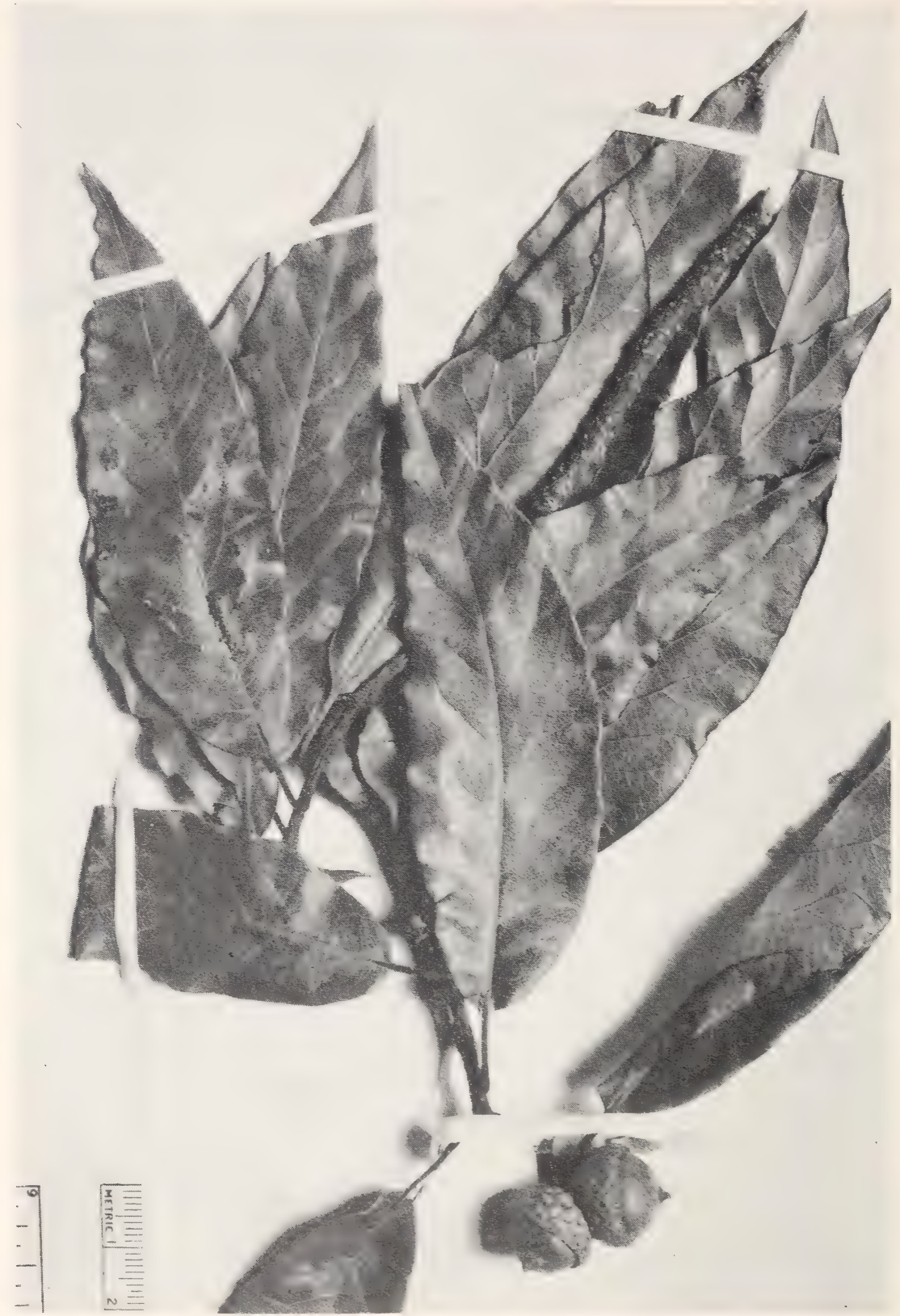

Quercus scemanni Liebm. A representative specimen from Costa Rica (Stork $1745-\mathrm{F})$. 
Miscellaneous Publication 477. U. S. Dept. of Agriculture

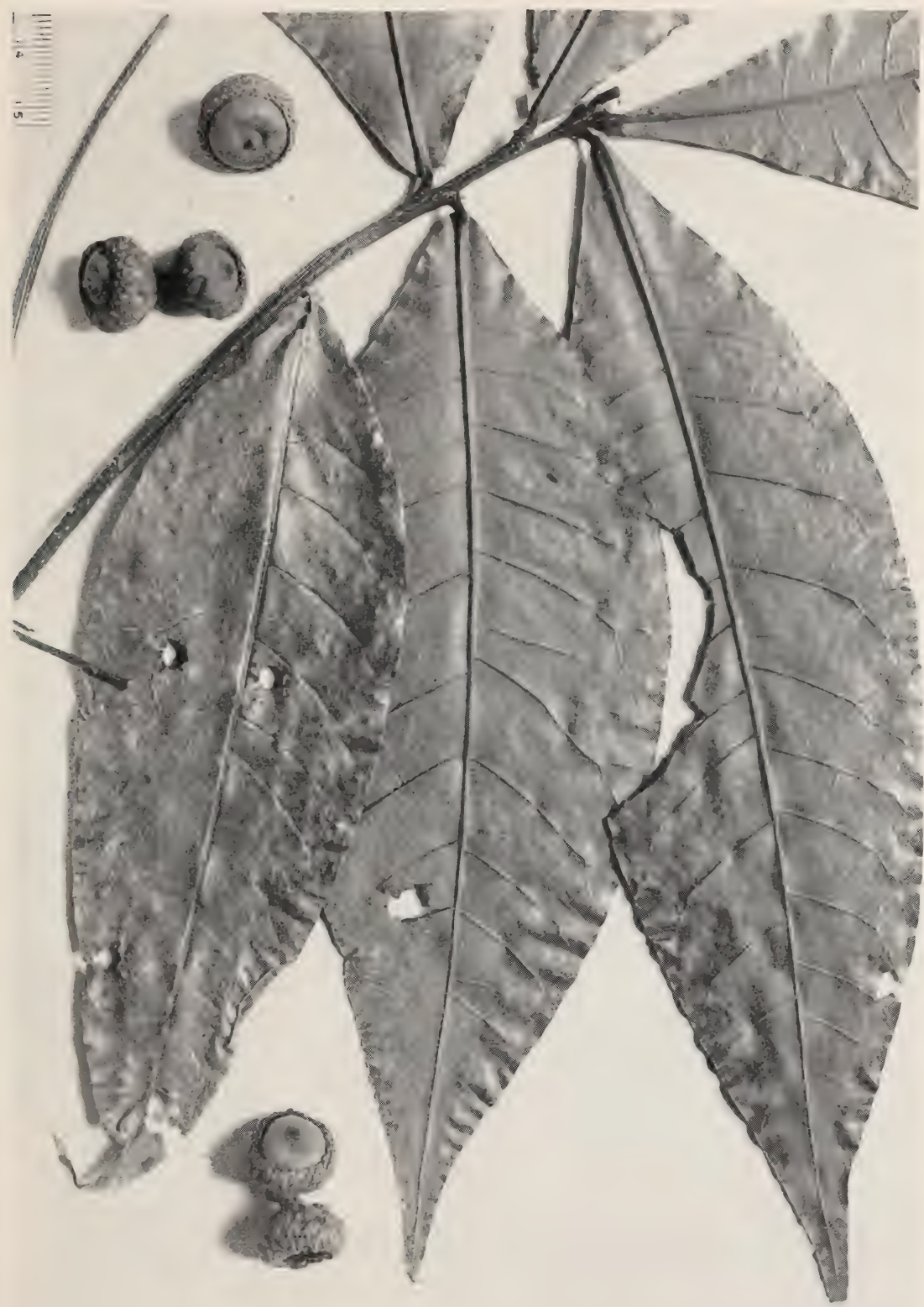

Quercus gulielmi-treleasei sp. nov. Type from Panama (Seibert :26-MBG). 


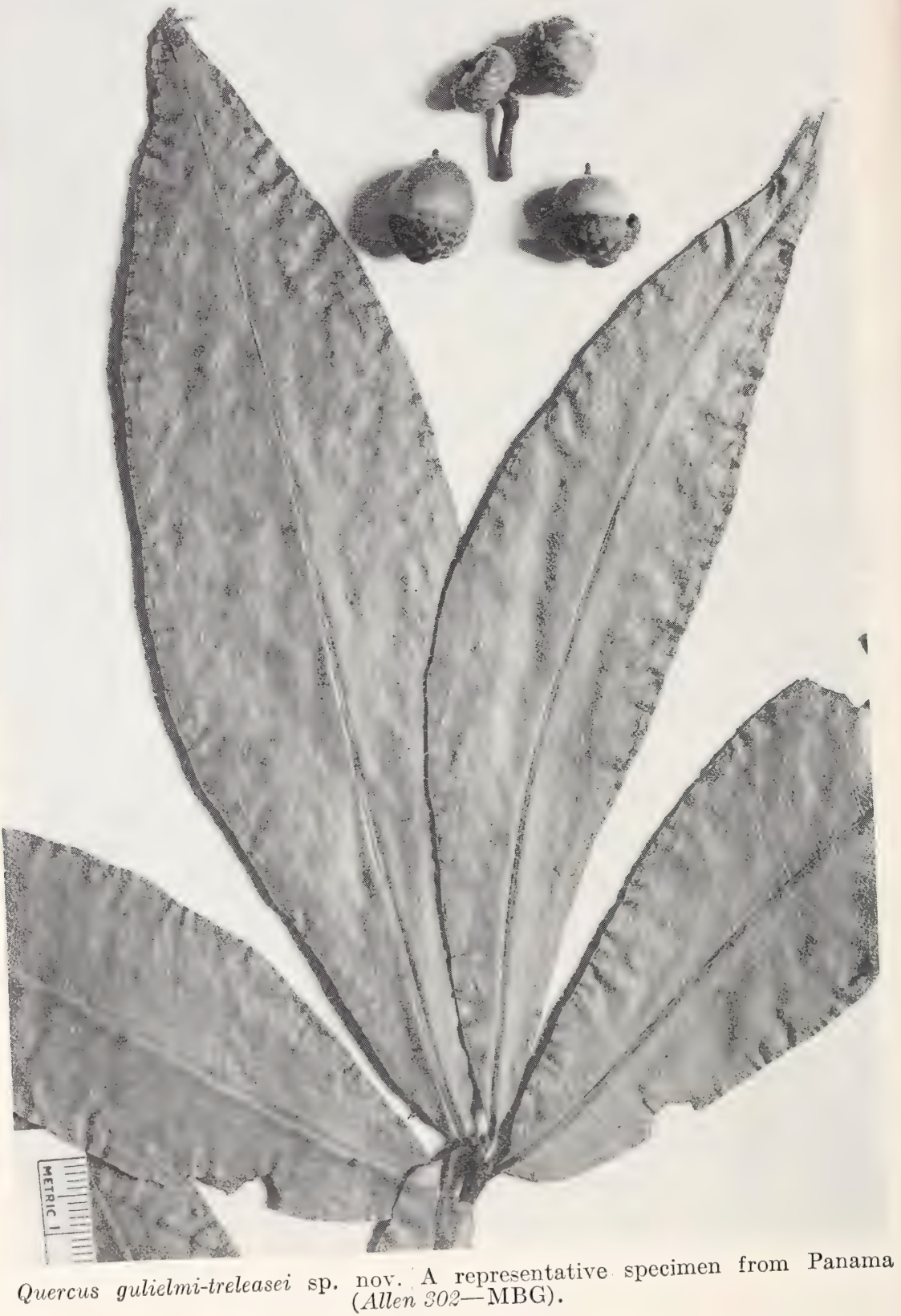




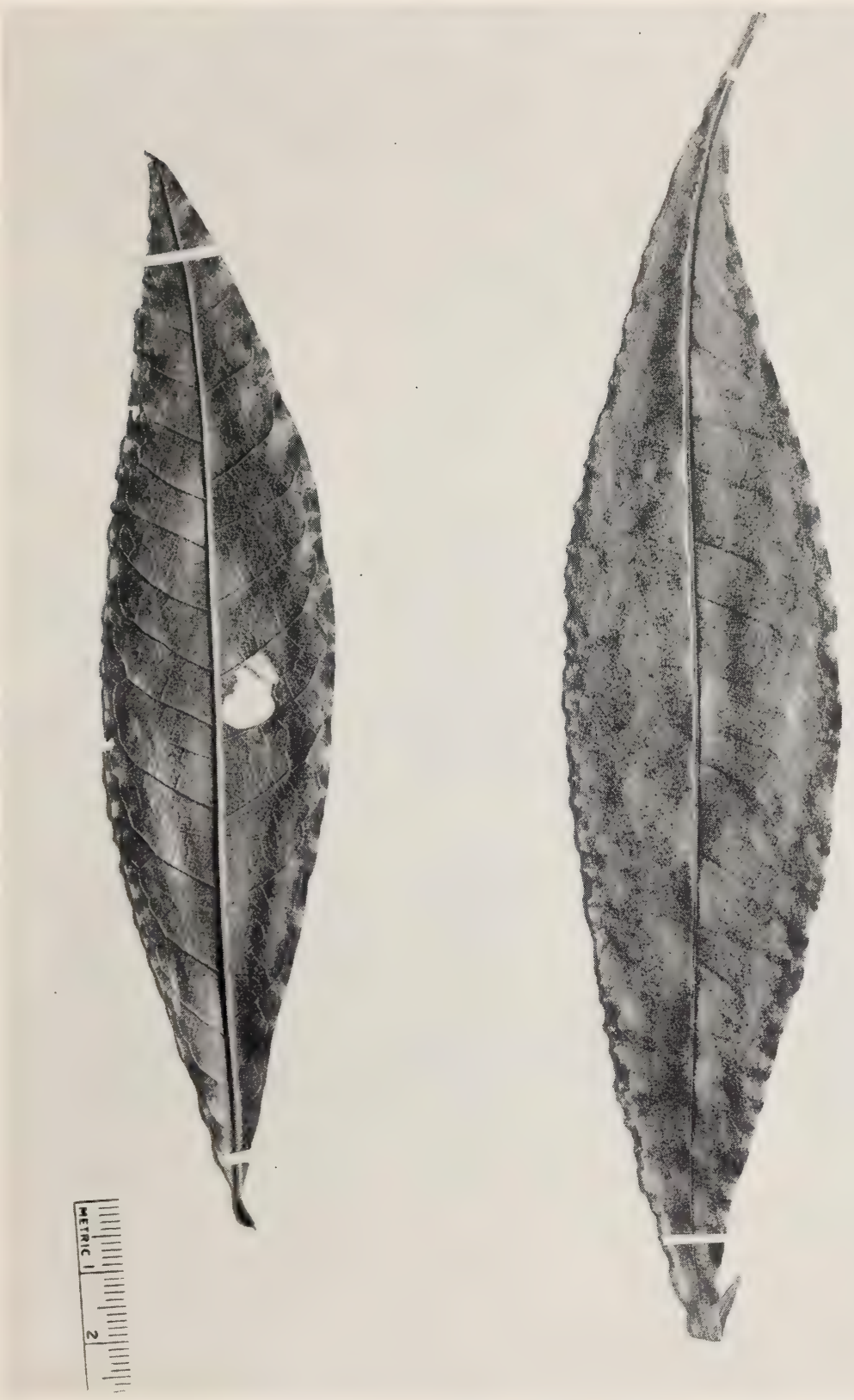

Quercus crispifolia Trel. Type from Chiapas, Mexico (Reeves 4-Ill). 
174 IISC. PLBLICATION 47 , U. S. DEPT. OF AGRICULTURE

Miscellaneous Publication 477, U. S. Dept. of Agriculture

PLATE 82


Quercus crispifolia Trel. Type of Q. incrassata Trel. from Chiapas, Mexico (Reeves i-Ill). 


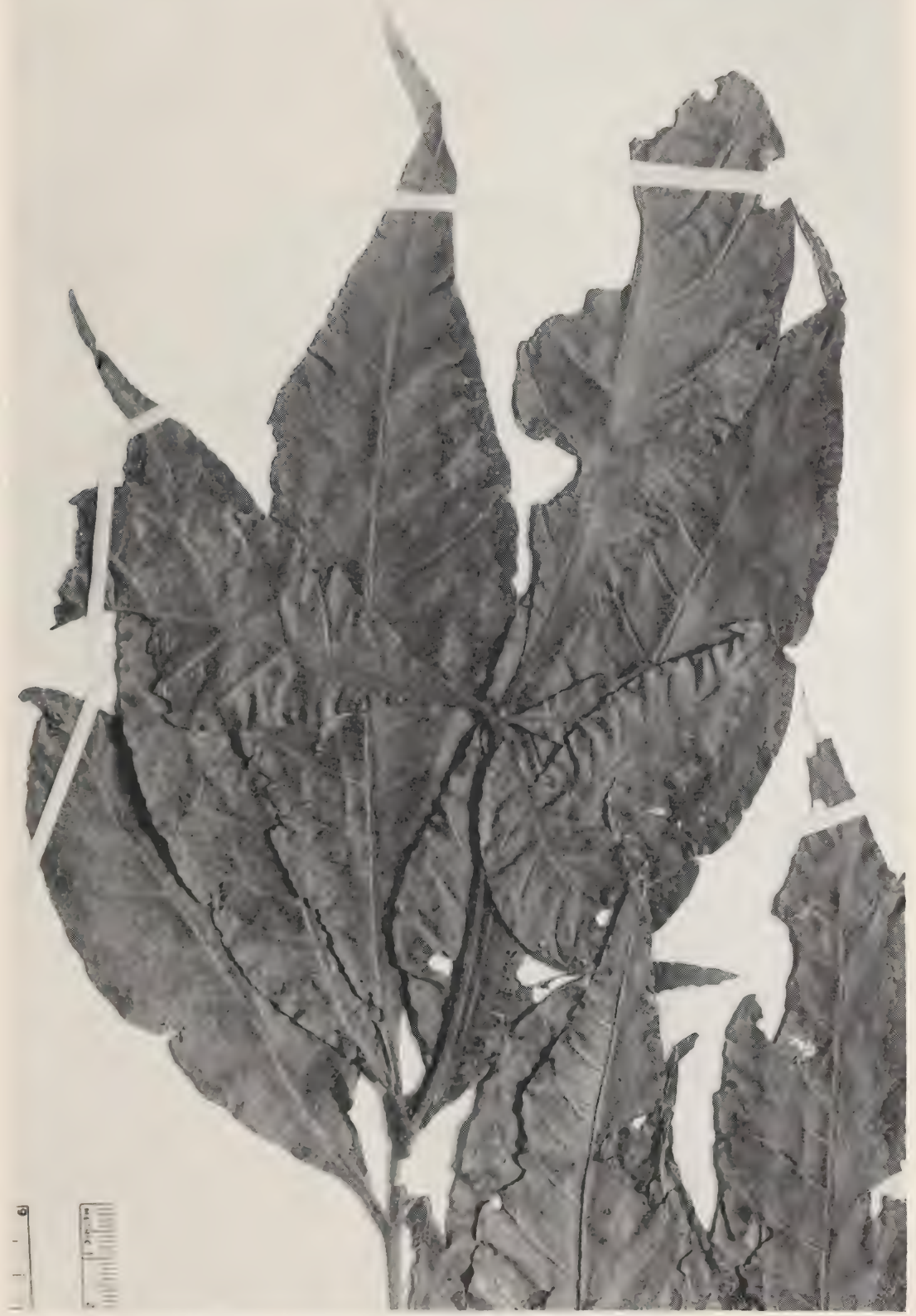

Quercus crispifolia Trel. A common variant from Guatemala (Standley 6856\%-F). 


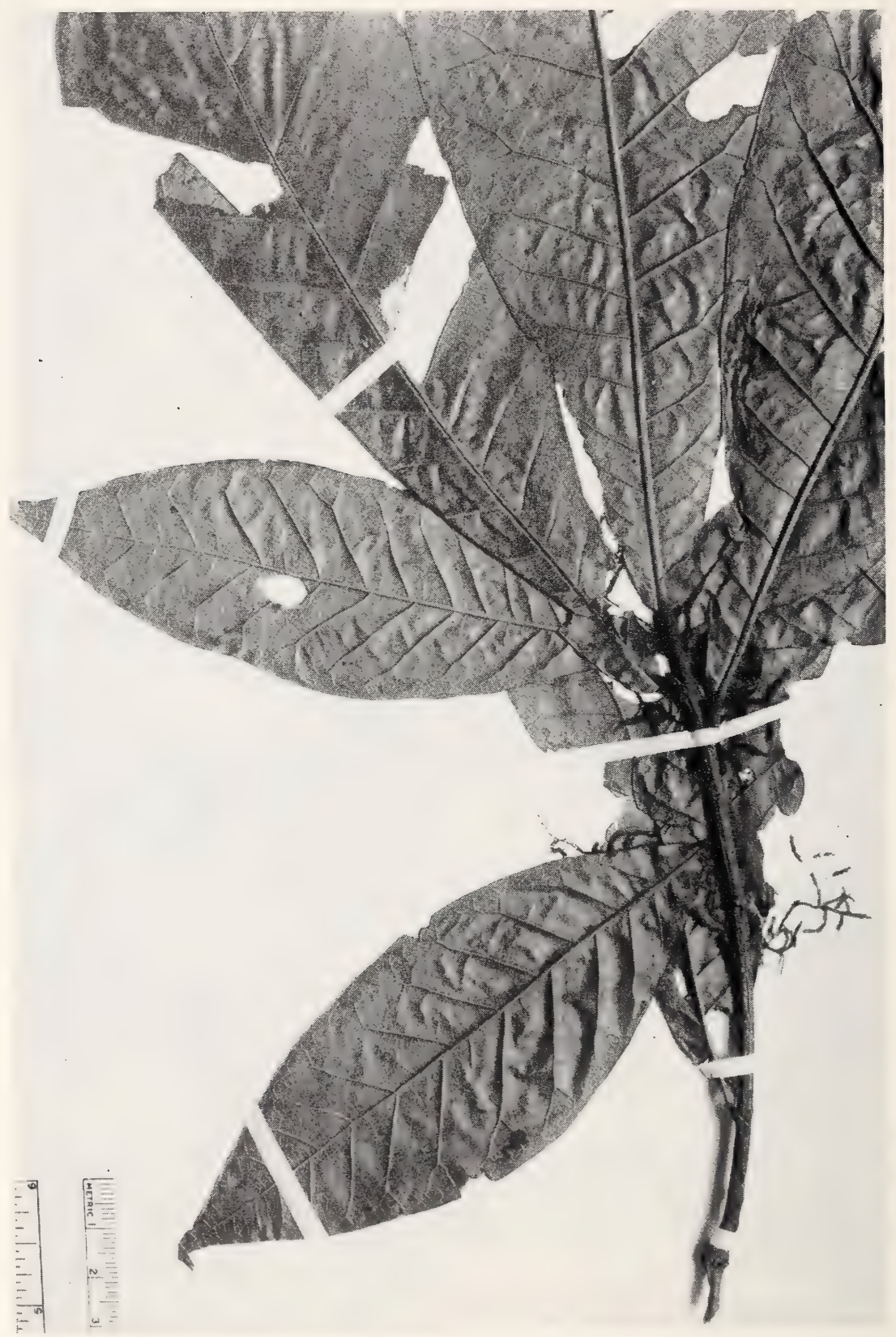

Quercus crispifolia Trel. A representative specimen from Guatemala (Steyermark 30808-F). 
THE CENTRAL AMERICAN SPECIES OF QUERCUS

177

Miscellaneous Publication 477, U. S. Dept. of Agriculture

PLATE 85

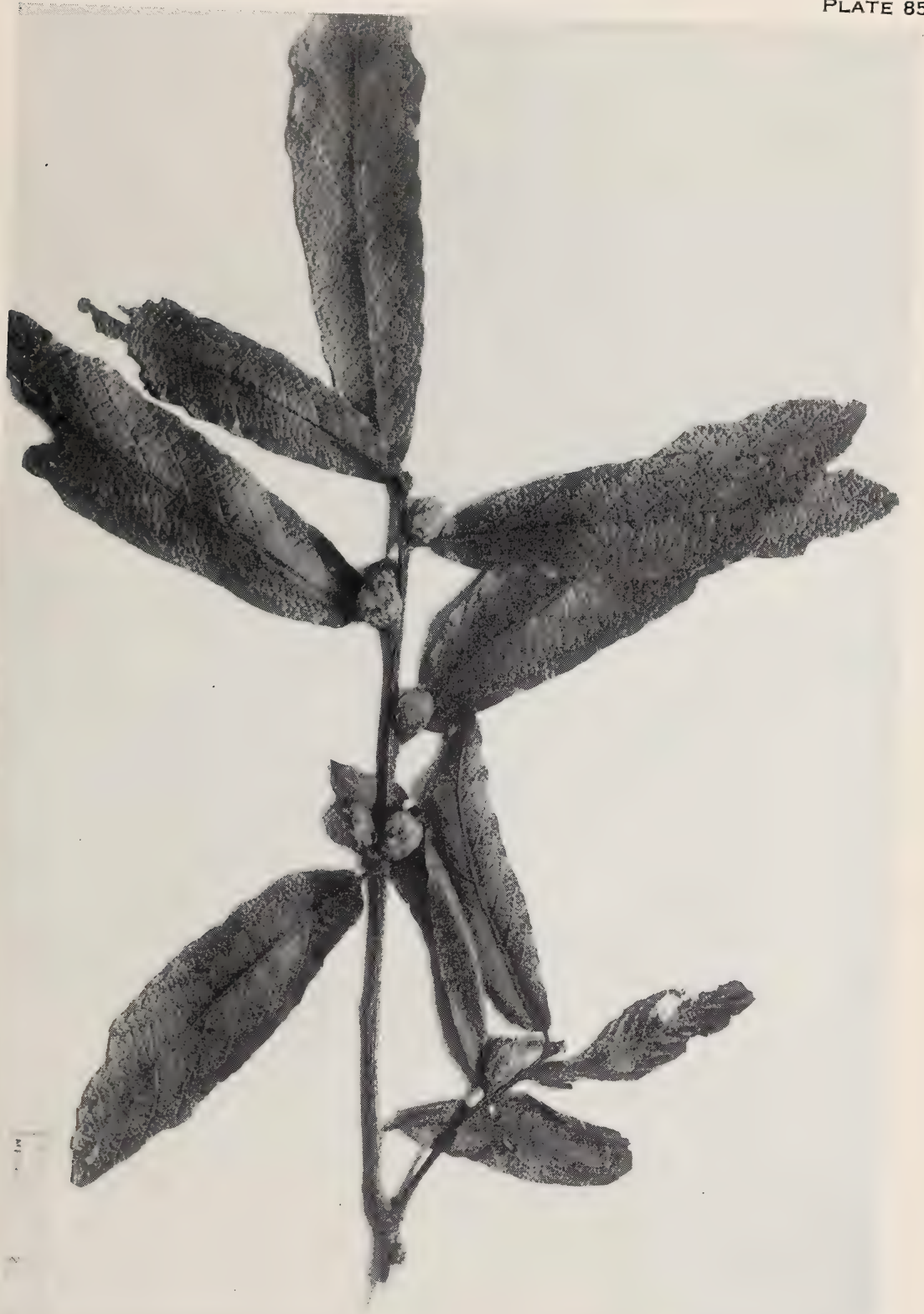

Quercus tristis Liebm. A representative specimen from Guatemala (Hayes July $186^{\circ} 0$-AA). 
Miscellaneous Publication 477, U. S, Dept. of Agriculture

PLATE 86

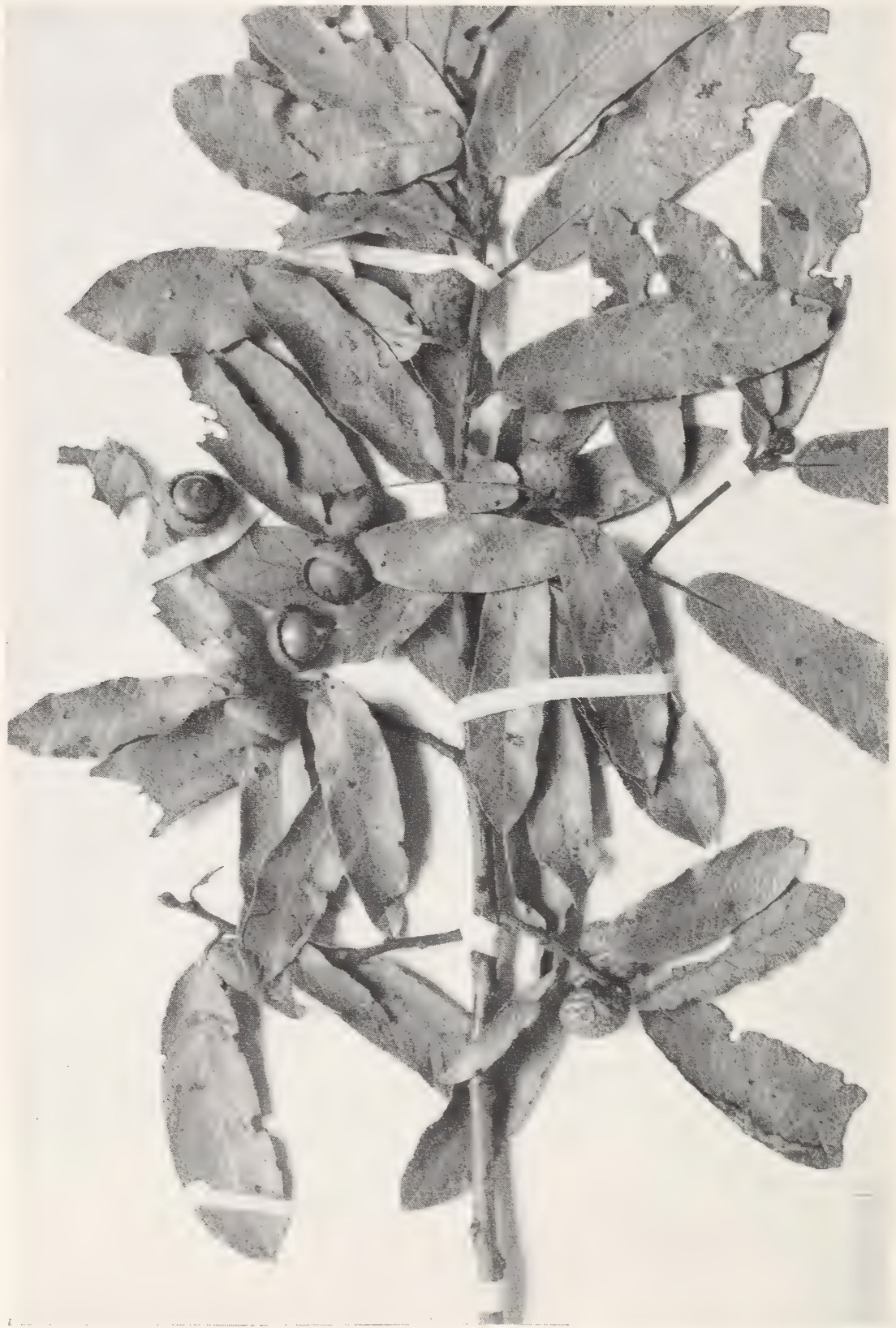

Quercus tristis Liebm. A representative specimen from Guatemala (Skutch 1105-F). 


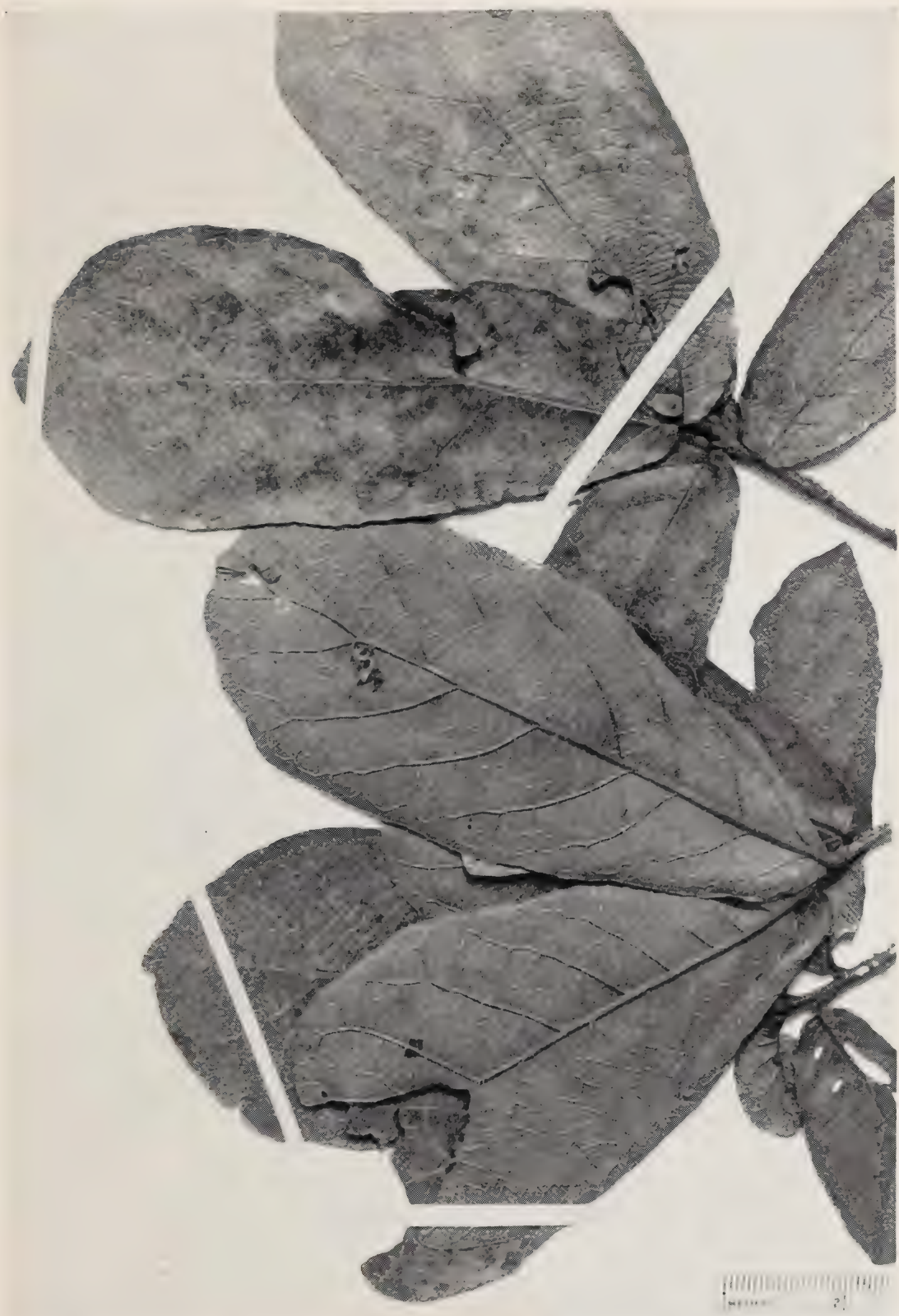

Quercus tristis Liebm. A common variant (shade form) from Guatemala (Standley 64372-F). 


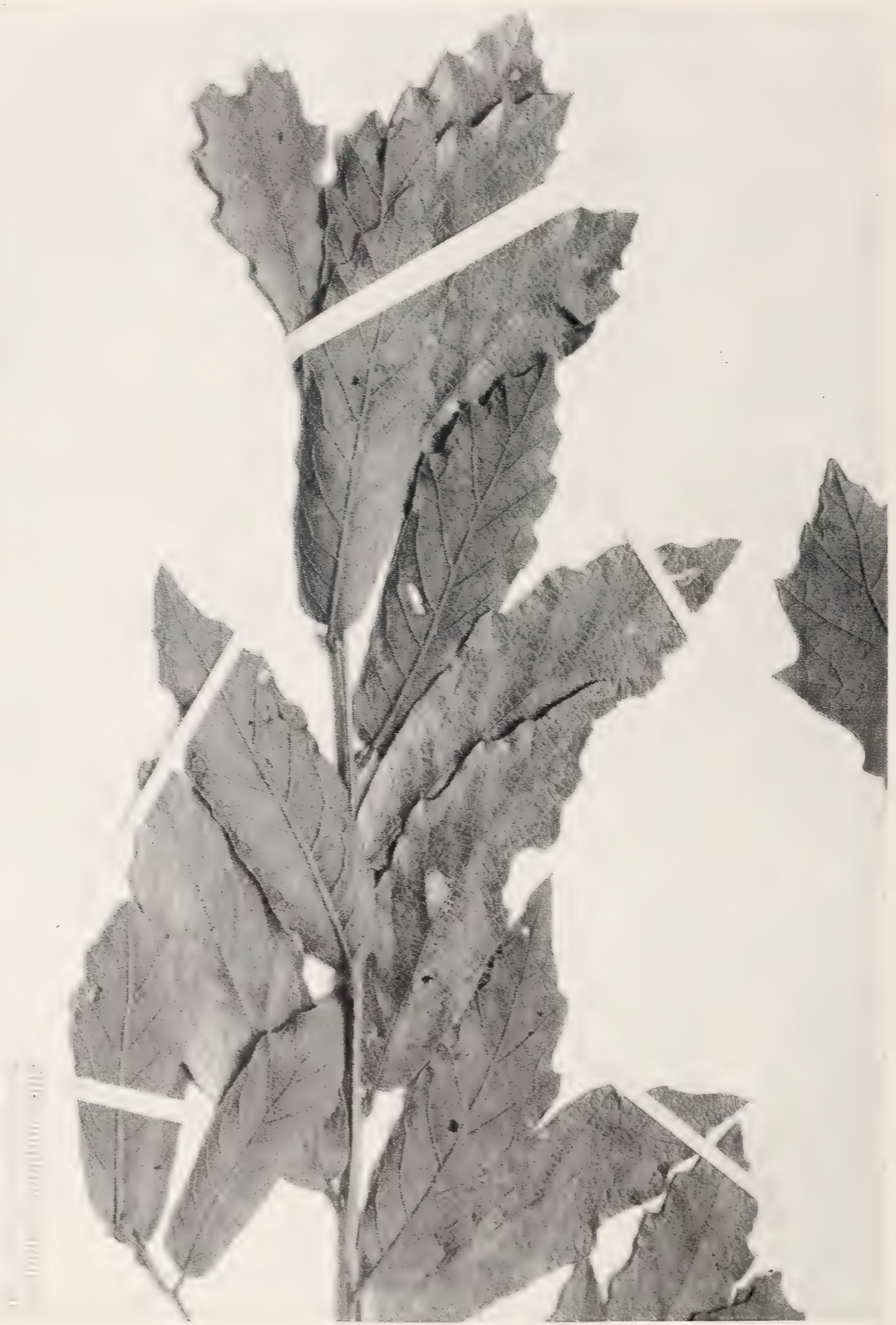

Quercus tristis Liebm. A characteristic juvenile form or stump sprout from Guatemala (Skinner without number-NY). 




Quercusbrachystachys Benth. A representativespecimen from Guatemala (Popenoe 681 -US). 


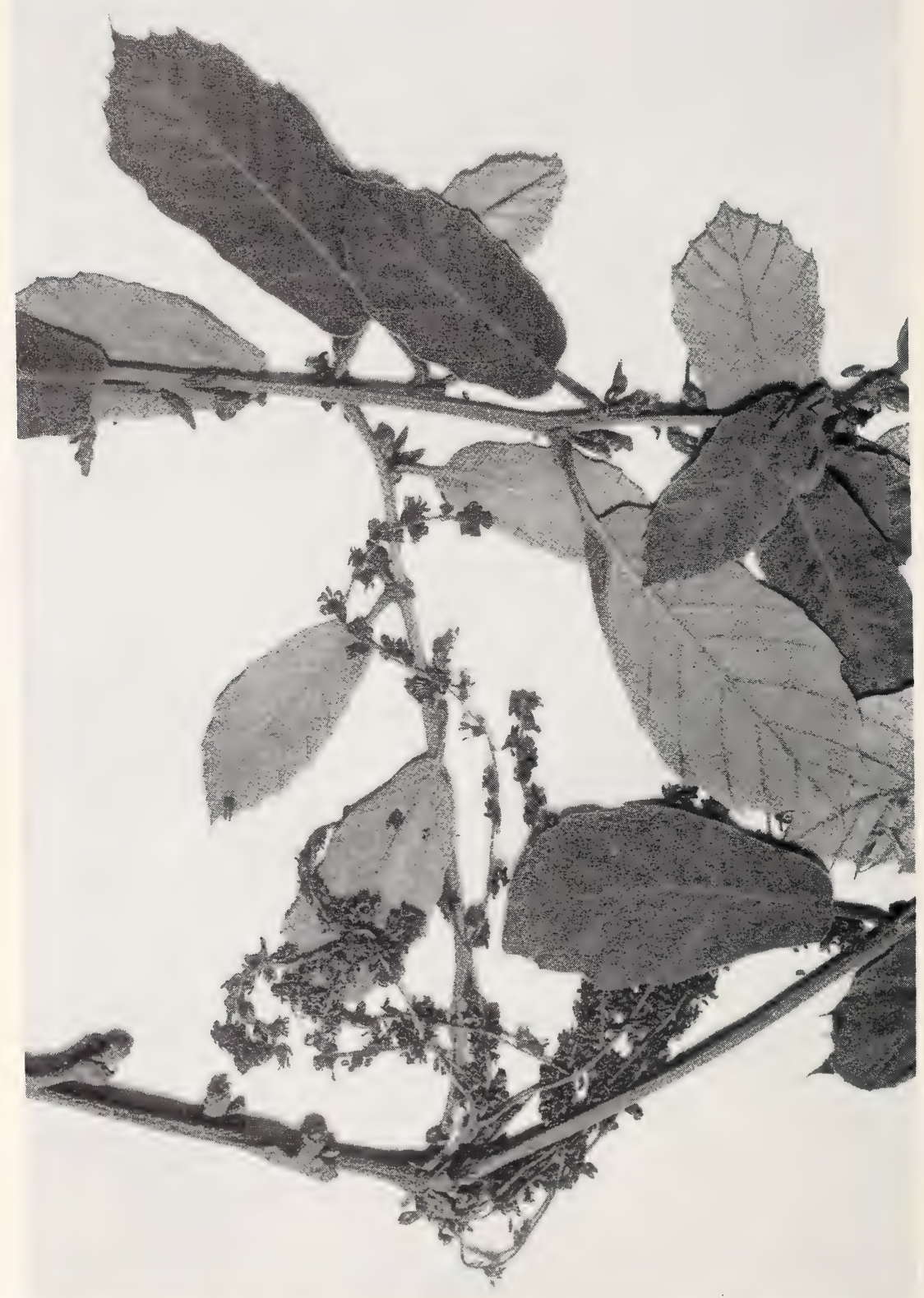

Quercusbrachystachys Benth. A characteristic flowering specimen from Guatemala (Trelease 46-Ill). 


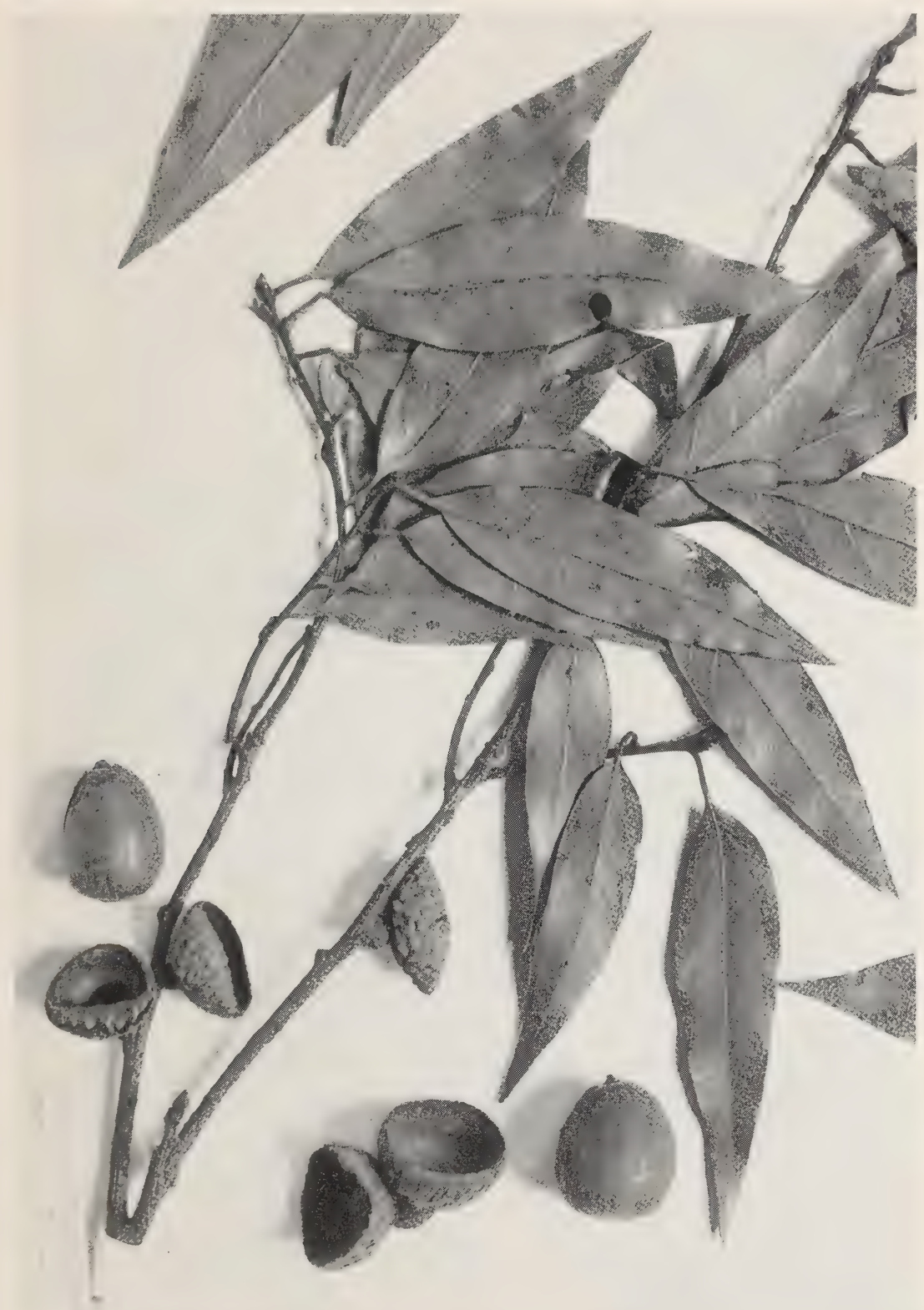

Quercus acatenangensis Trel. A characteristic specimen from Guatemala, illustrated under another number as the type of $Q$. donnell-smithii Trel. in his monograph (Smith, 2629-US). 


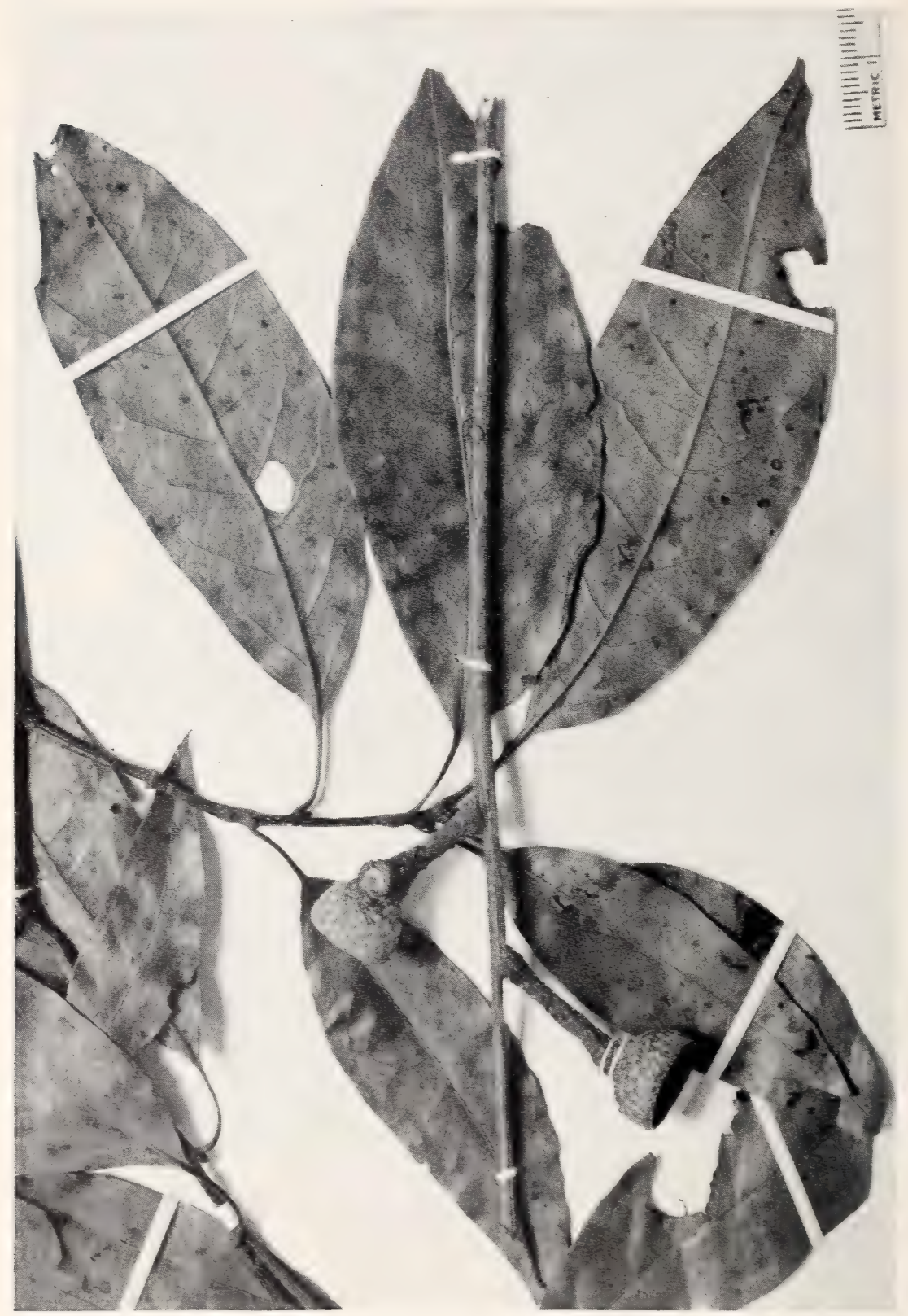

Quercus acatenangensis Trel. A common variant, the type of Q. ambivenulosa Trel. from Guatemala (Skutch 14-U'S). 


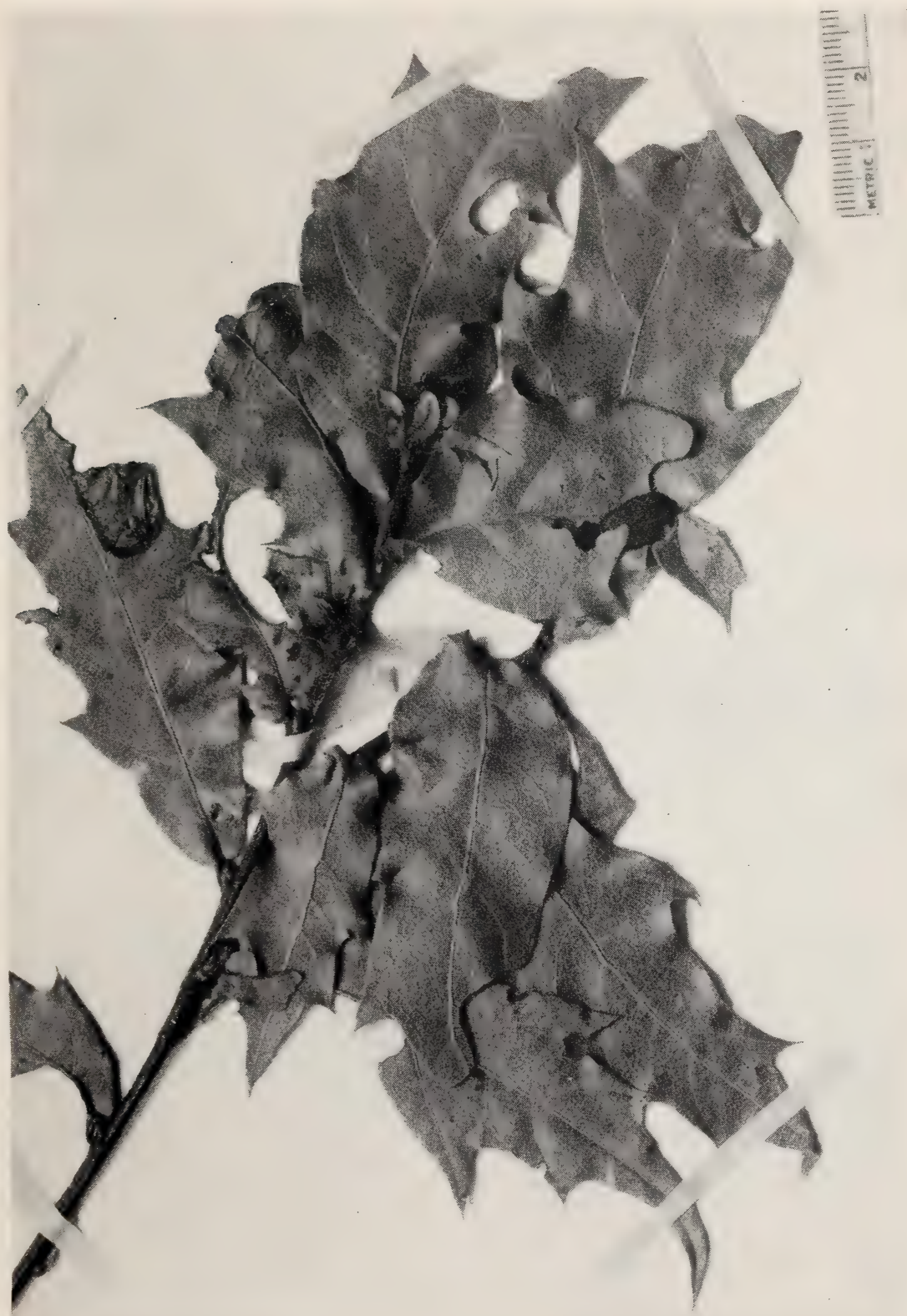

Quercus acatenangensis Trel. A characteristic stump sprout from Guatemala (Steyermark 36916-F). 


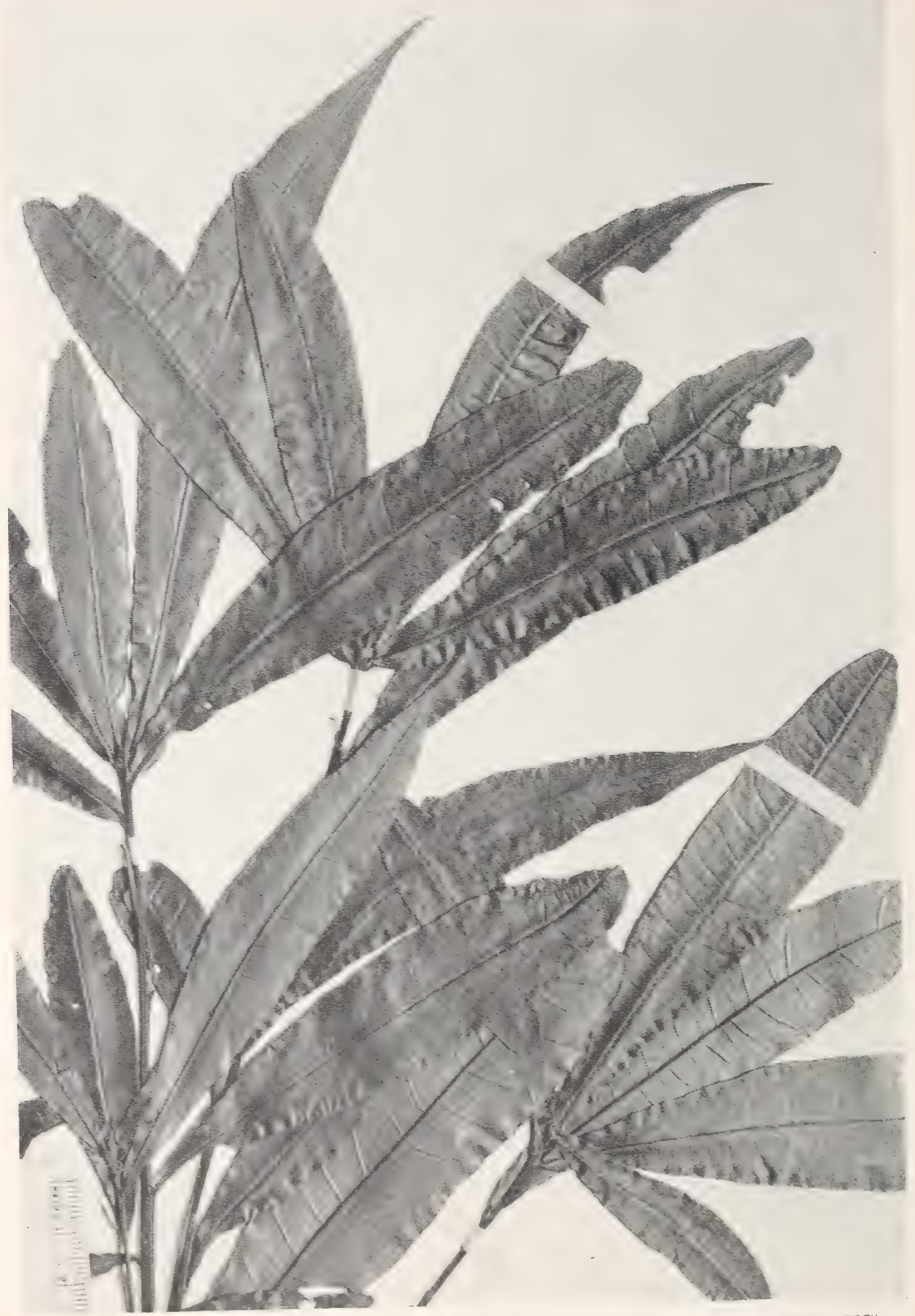

Queicus flagellifera Trel. Type from Guatemala (Cook and Griggs 60i-L'S). 


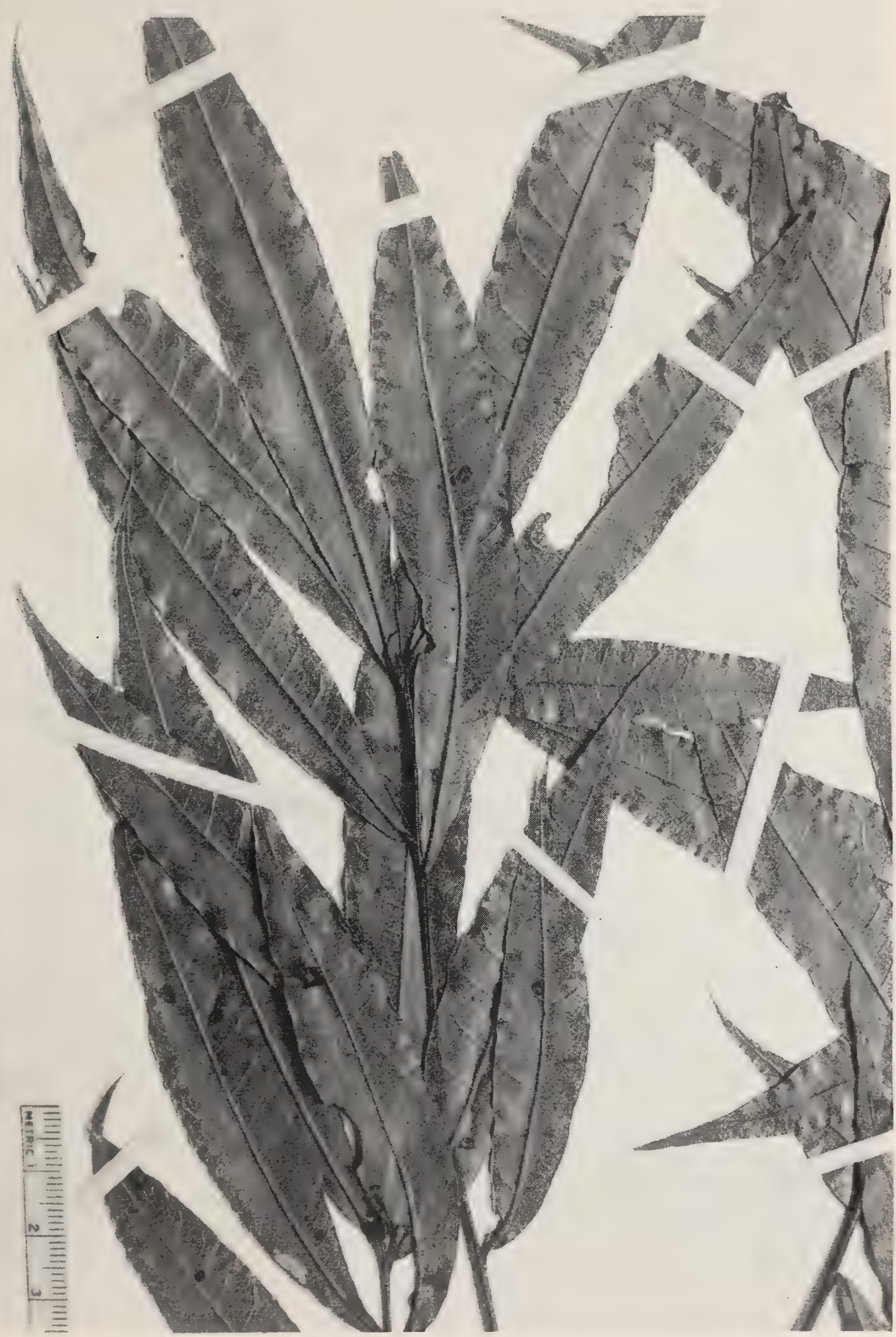

Quercus flagellifera Trel. A characteristic specimen from Guatemala (Steyermark $\left.314^{7} 6-\mathrm{F}\right)$. 


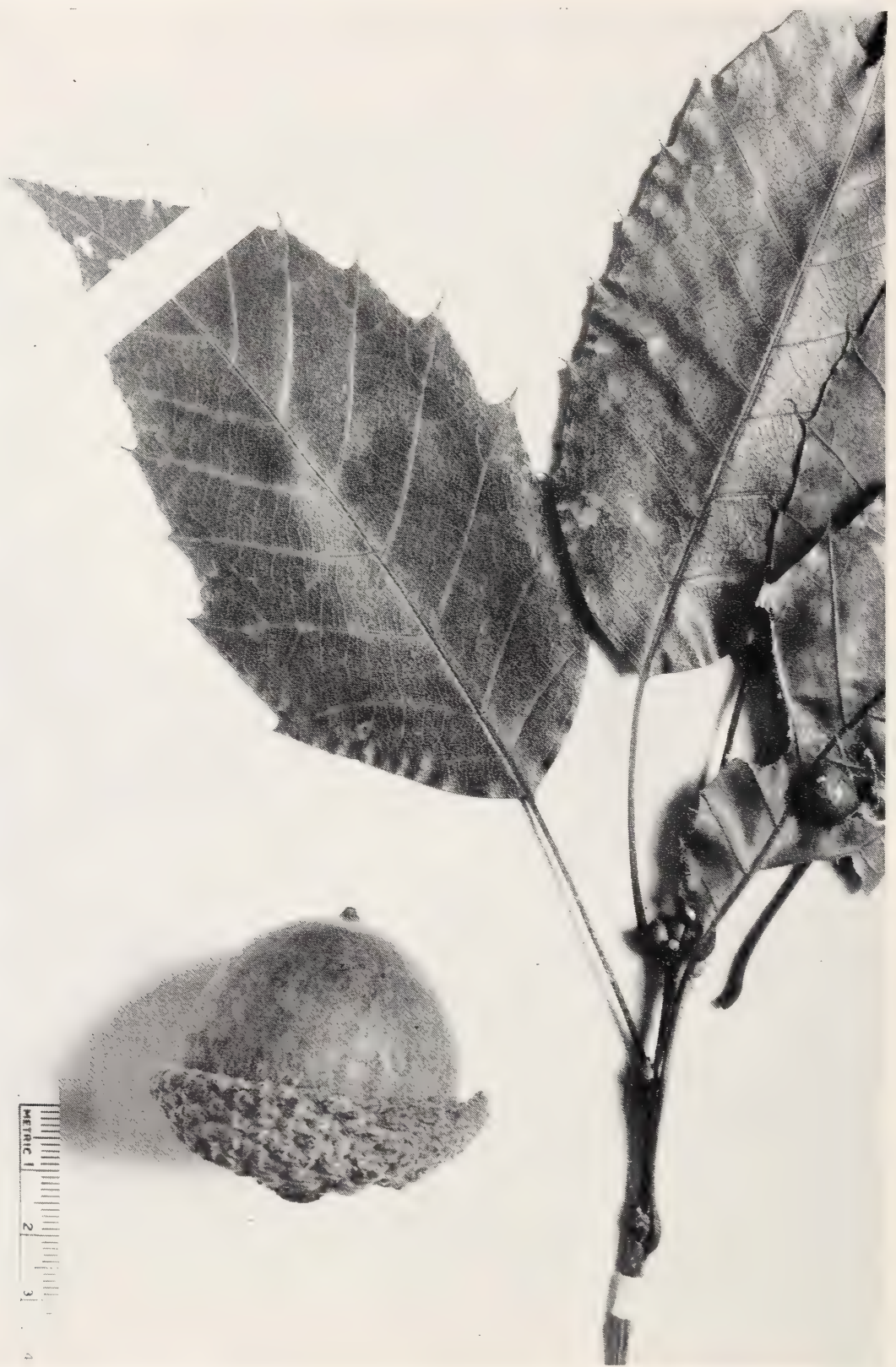

Quercus skinneri Benth. A representative specimen from Guatemala (Türckheim 3899-US). 


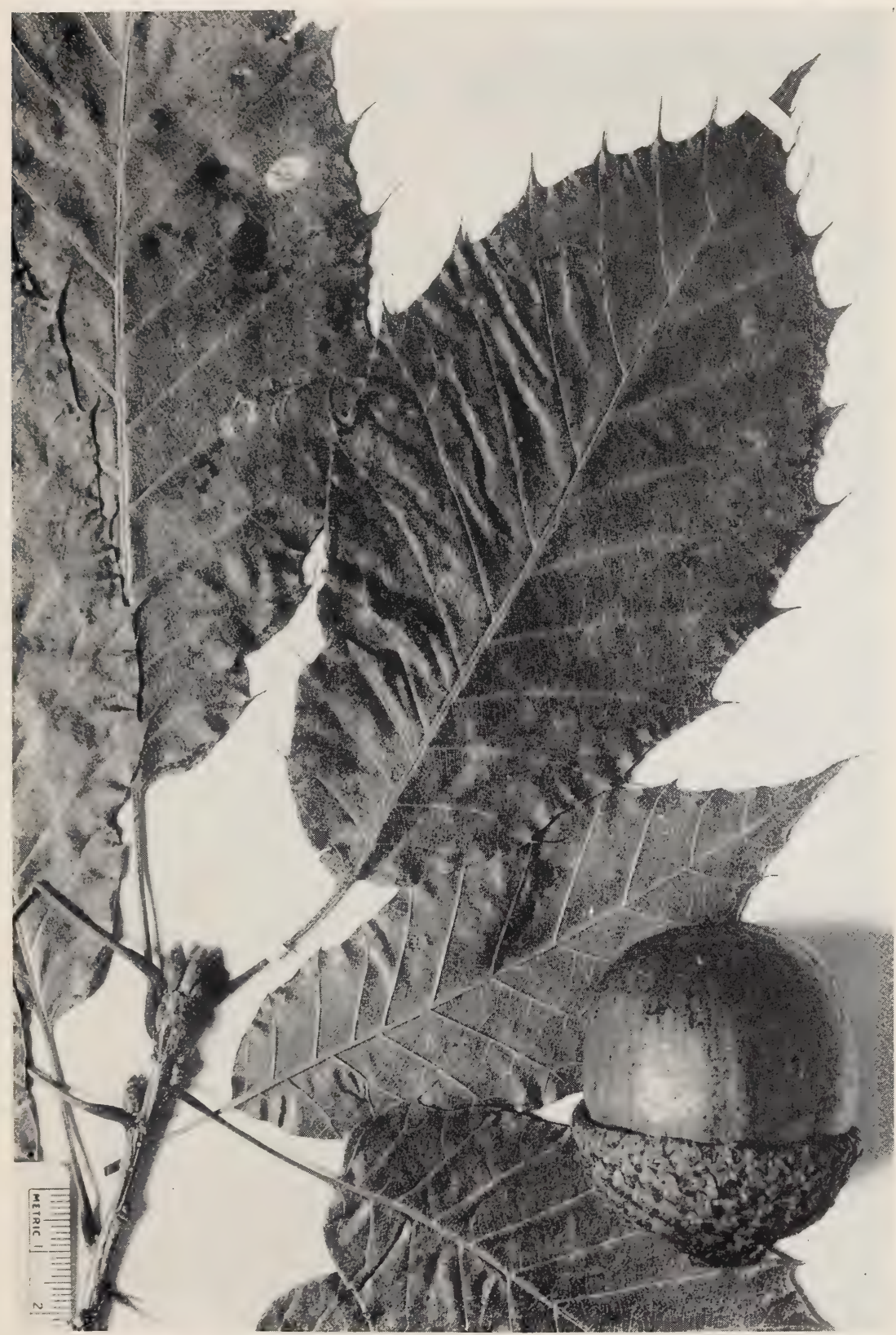

Quercus skinneri Benth. Type of $Q$. hemipteroides C. H. Mull. from Guatemala (Skutch 1875-Ill). 
190 MIISC. PLBLICATION 477 , U. S. DEPT. OF AGRICULTURE

Miscellaneous Publication 477, U. S. Dept. of Agriculture

PLATE 98

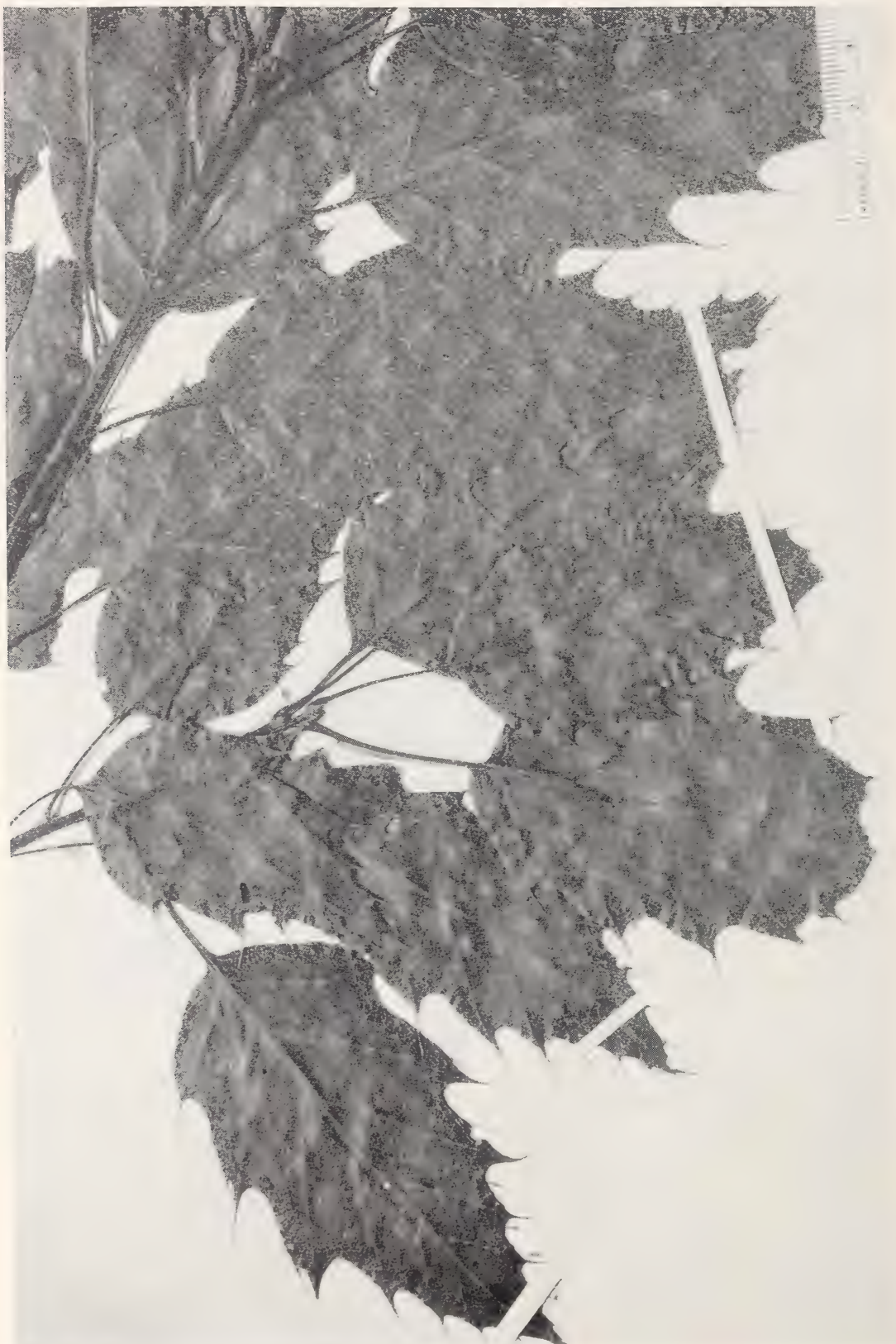

Quercus skinneri Benth. Isotype from Guatemala (Hartweg 615-NY). 


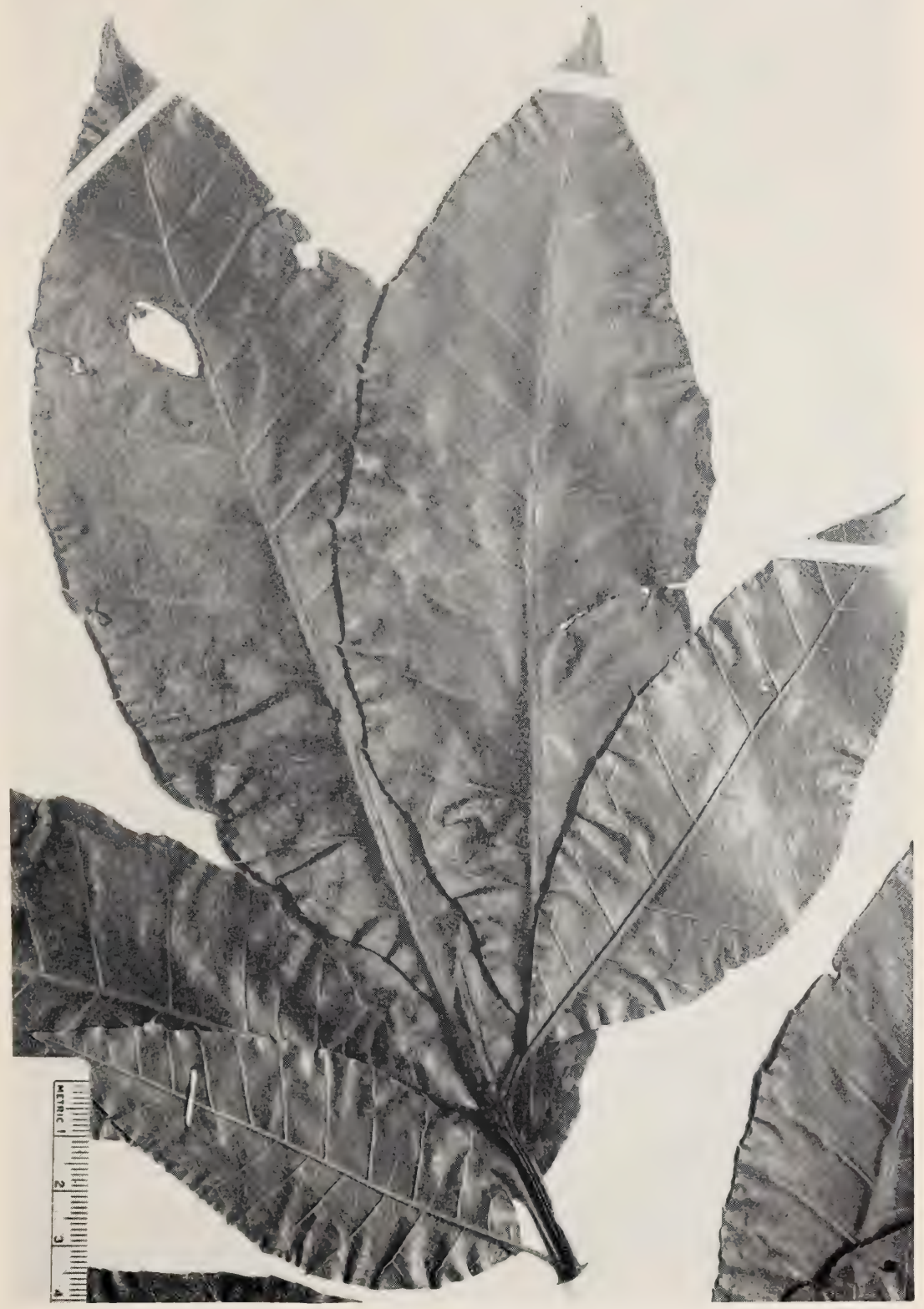

Quercus skinneri Benth. A variant from Guatemala (Steyermark 37193-F). 
Miscellaneous Publication 477, U. S. Dept. of Agriculture

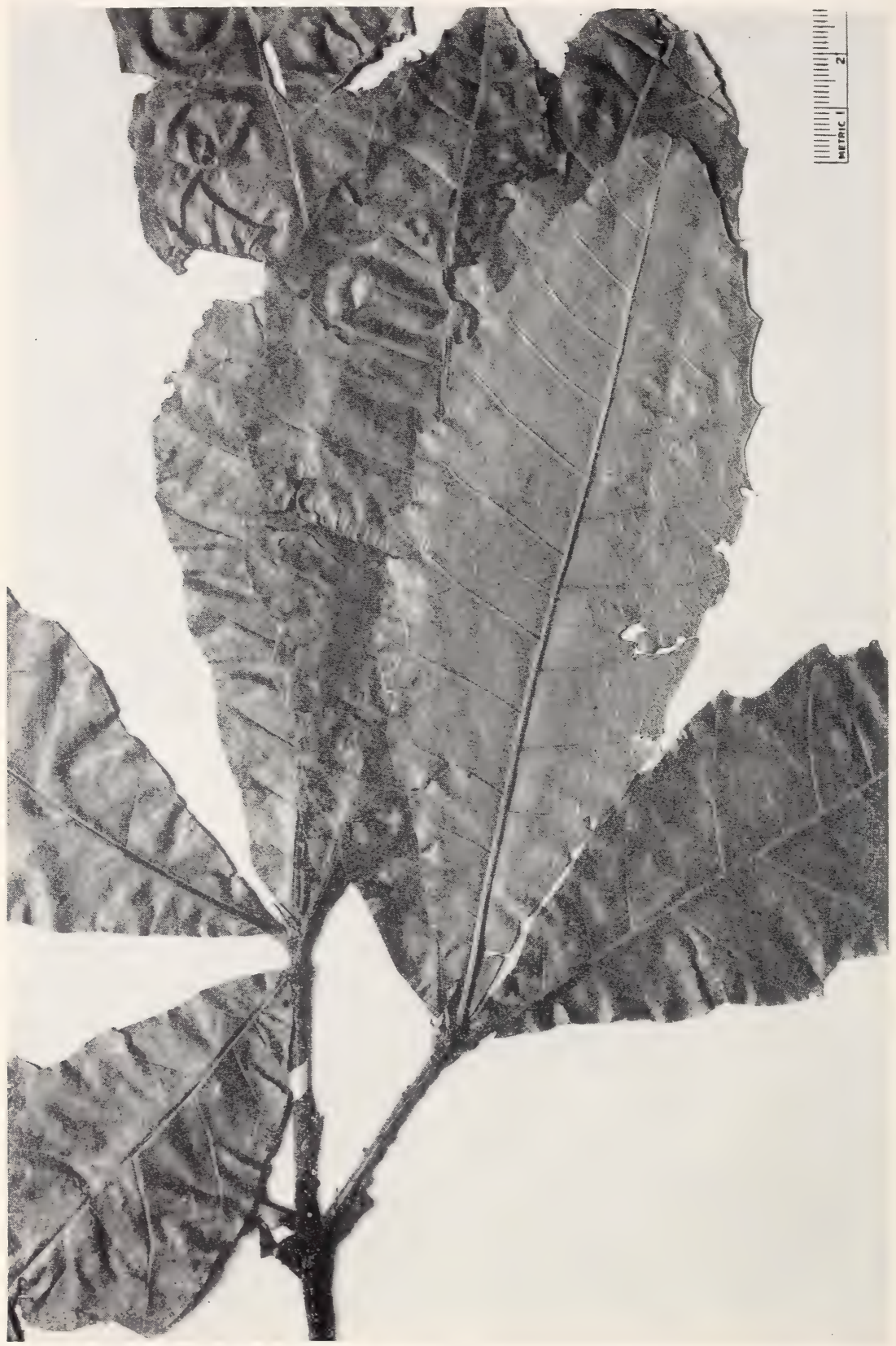

Quercus skinneri Benth. A variant from Honduras, isotype of Q. trichodonta Trel. (Yuncker, Dawson, and Youse 6116-DeP). 


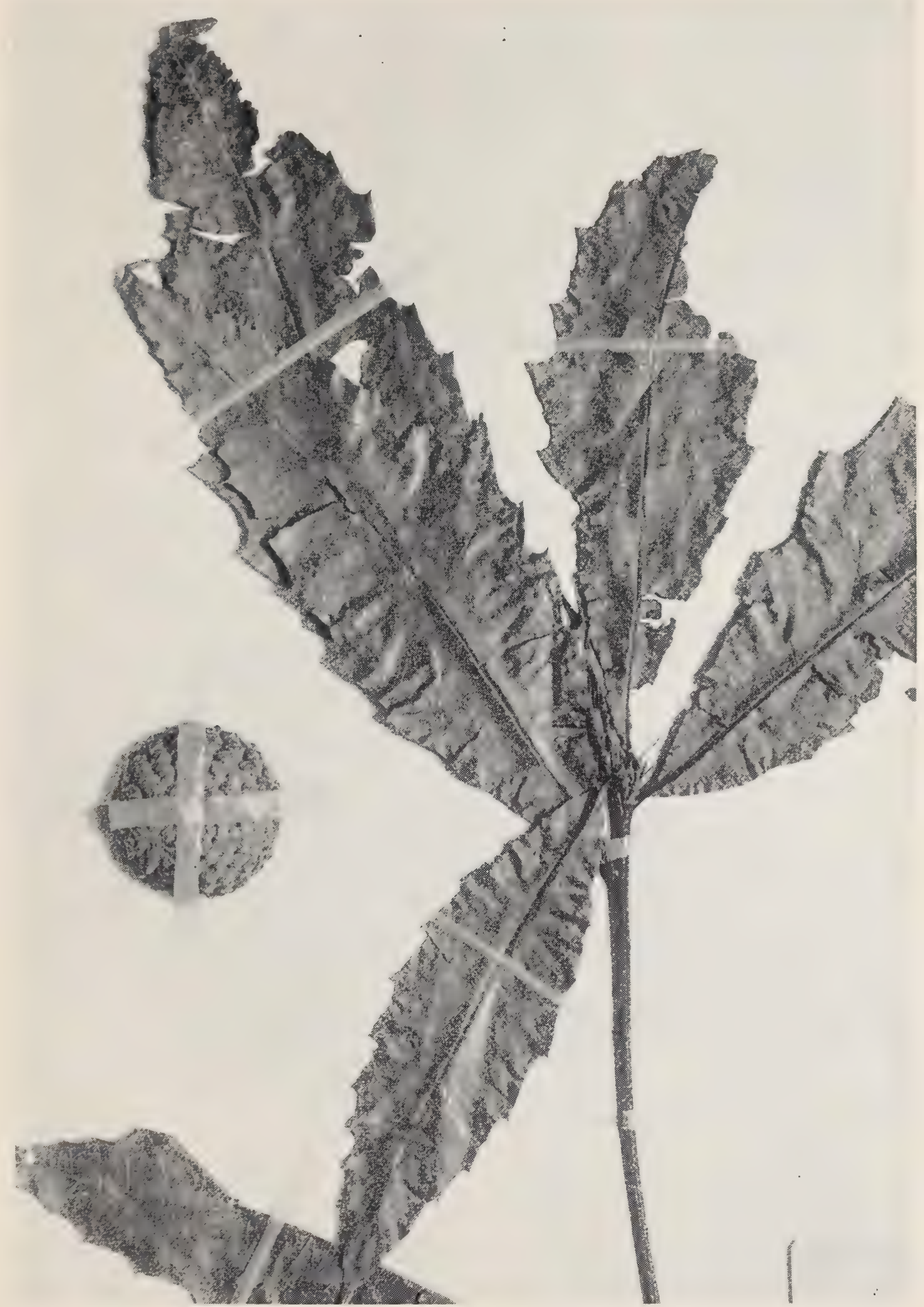

Quercus skinneri Benth. A variant from Chiapas, Mexico, isotype of Q. chiapasensis Trel. (Purpus 6999 -US). 
194 MISC. PUBLICATION 477 , U. S. DEPT. OF AGRICULTURE

Miscellaneous Publication 477, U. S. Dept. of Agriculture

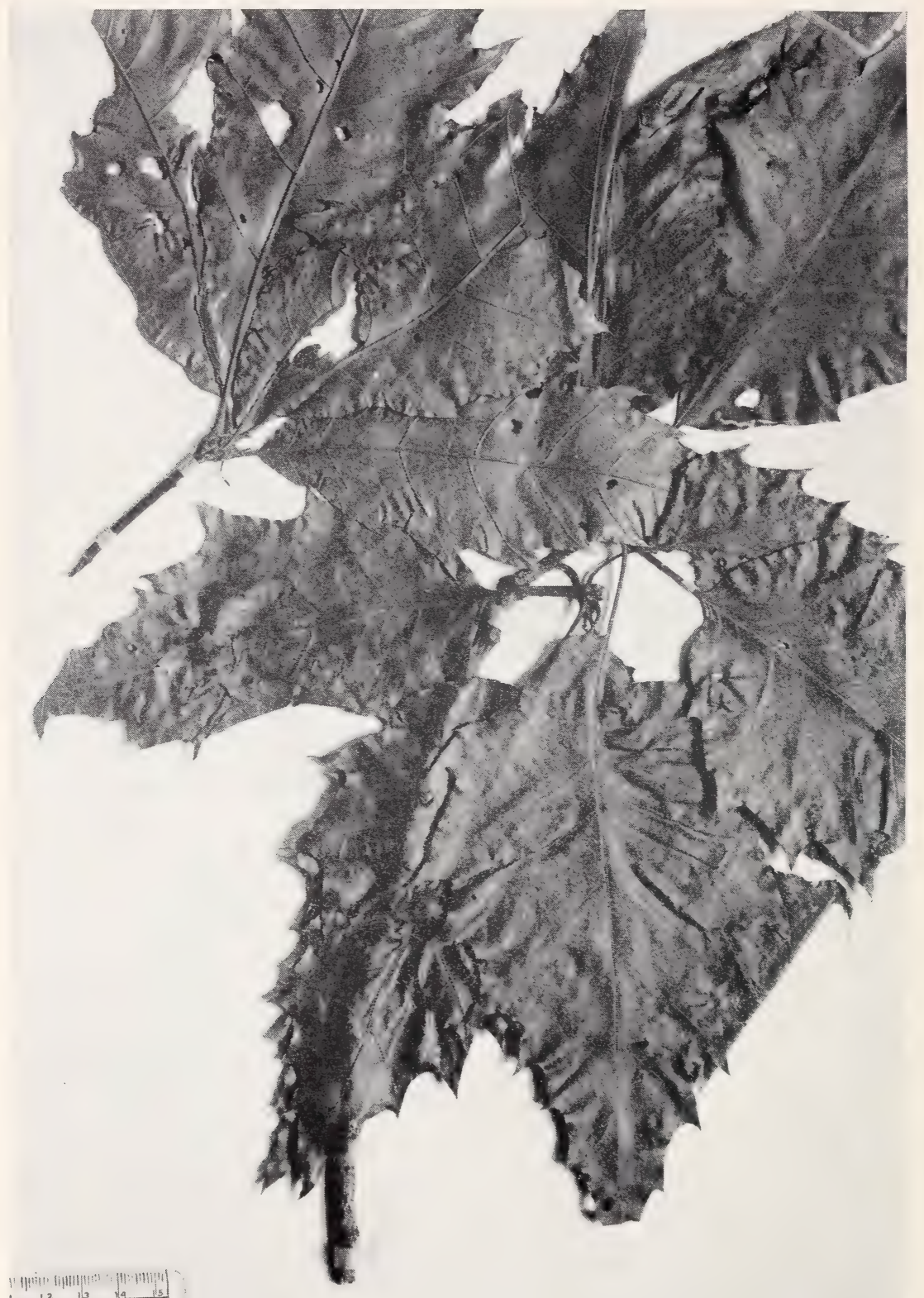

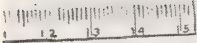

Quercus skinneri Benth. Topotype of Q. chiapasensis Trel. from Chiapas, Mexico (Purpus 6999'-US). 


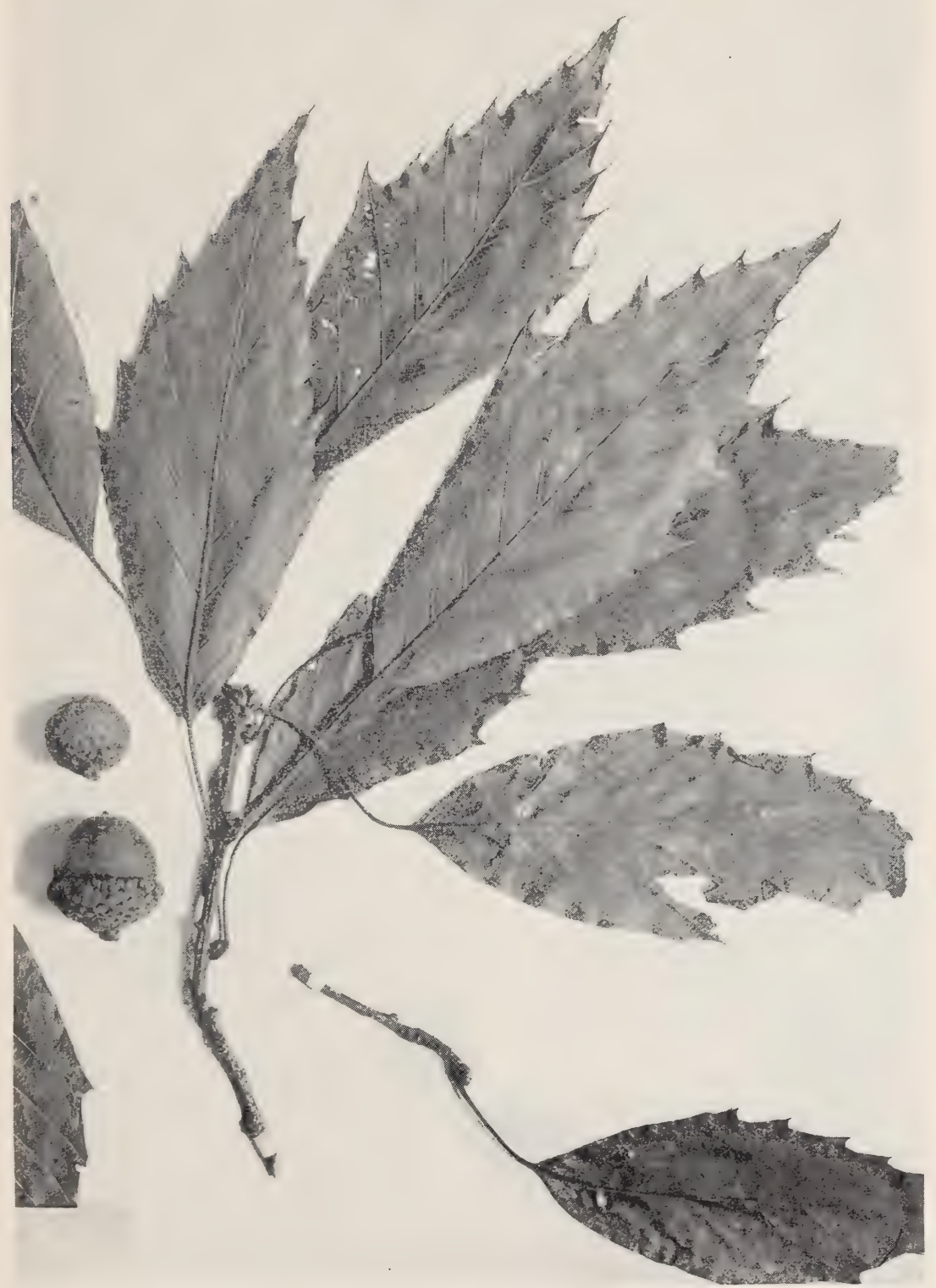

Quercus skinneri Benth. A variant from El Salvador, type of Q. salvadorensis Trel. (Calderon 1981-US). 
Miscellaneous Publication 477, U. S. Dept. of Agriculture

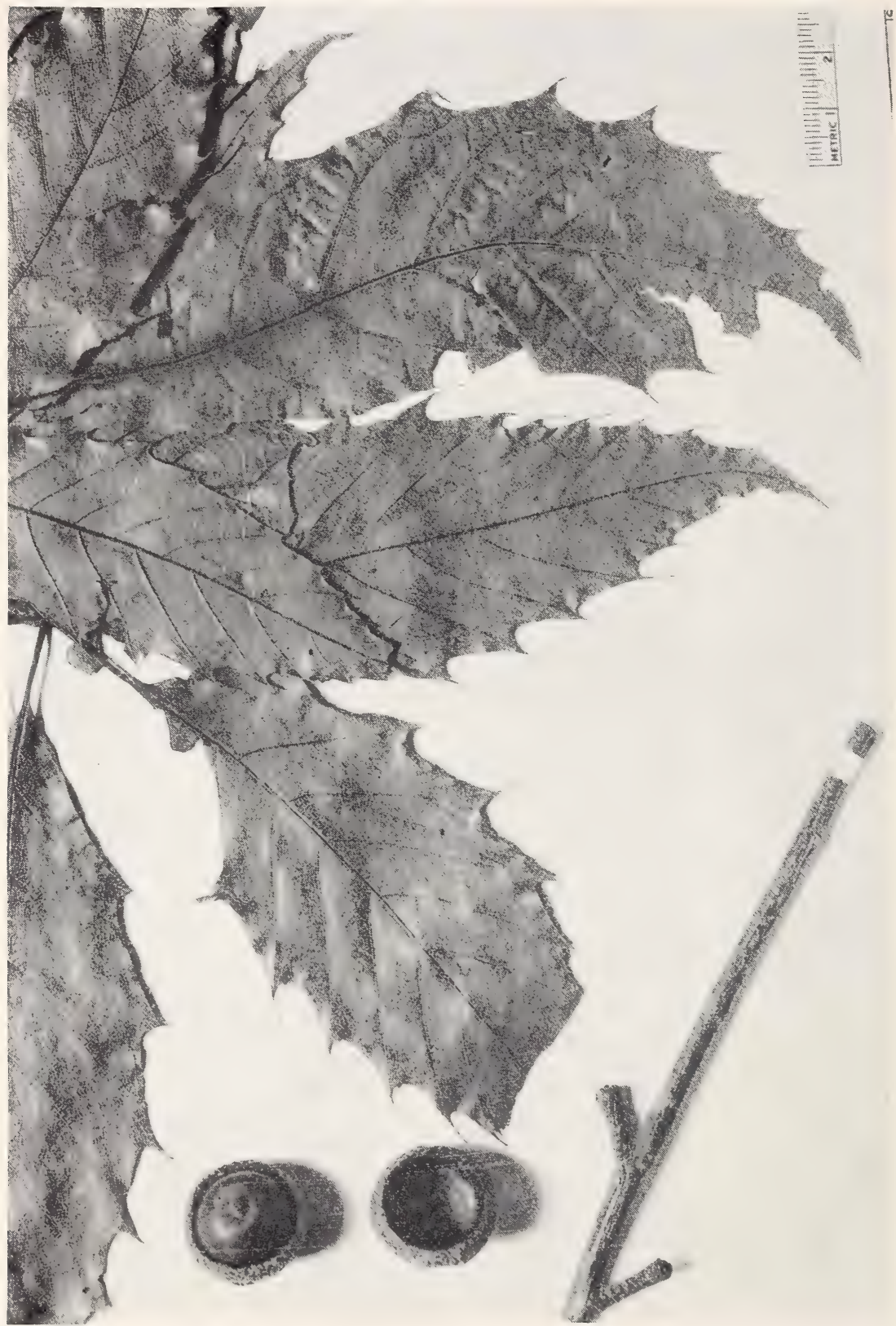

Quercus monserratensis sp. nov. Type from Chiapas, Mexico (Purpus 10091 -AA). 




Quercus conspersa Benth. A characteristic specimen from Guatemala (Deam $6087-\mathrm{Mi})$. 


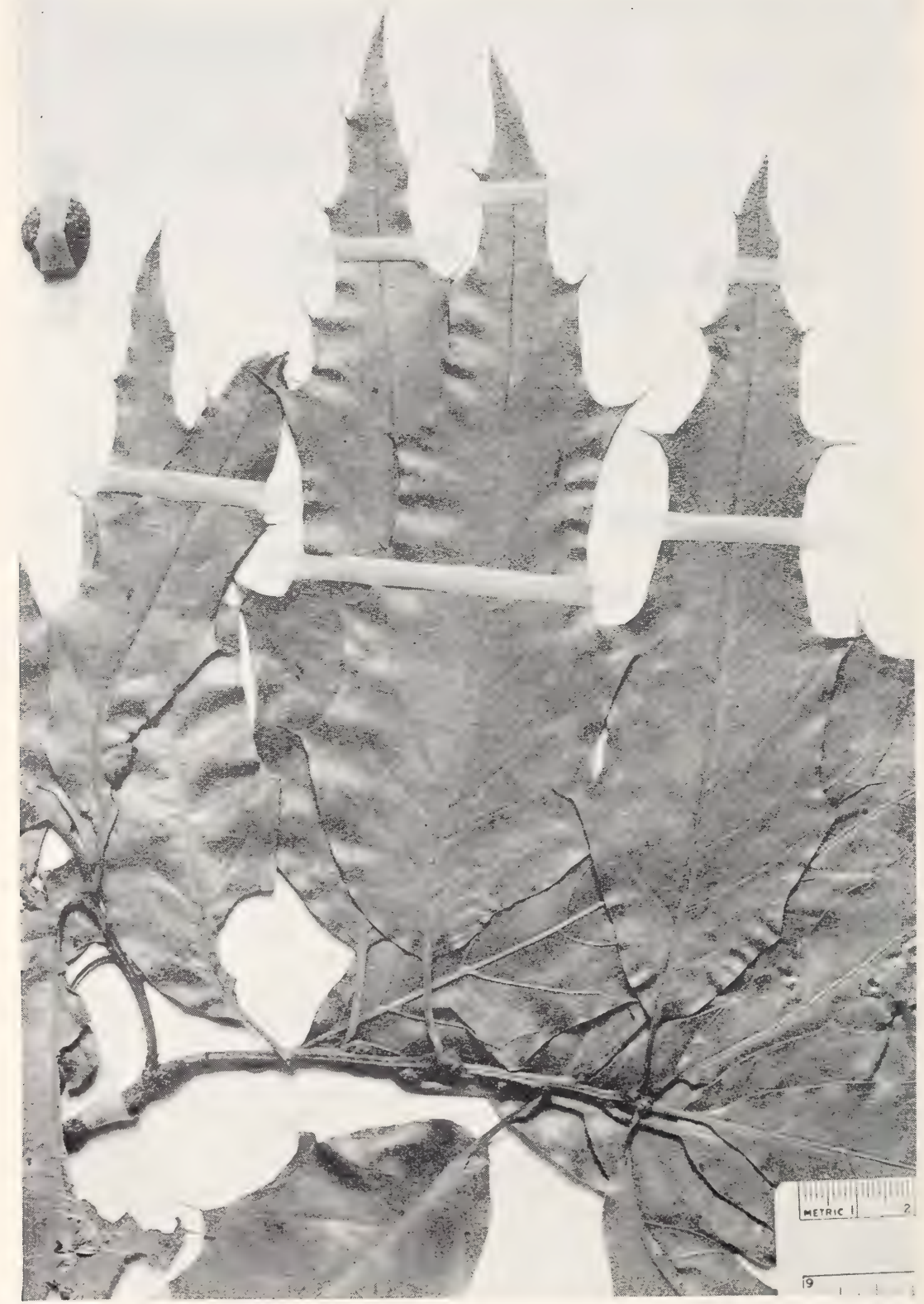

Quercus conspersa Benth. A common form from Guatemala (Cook and Doyle 282-US). 


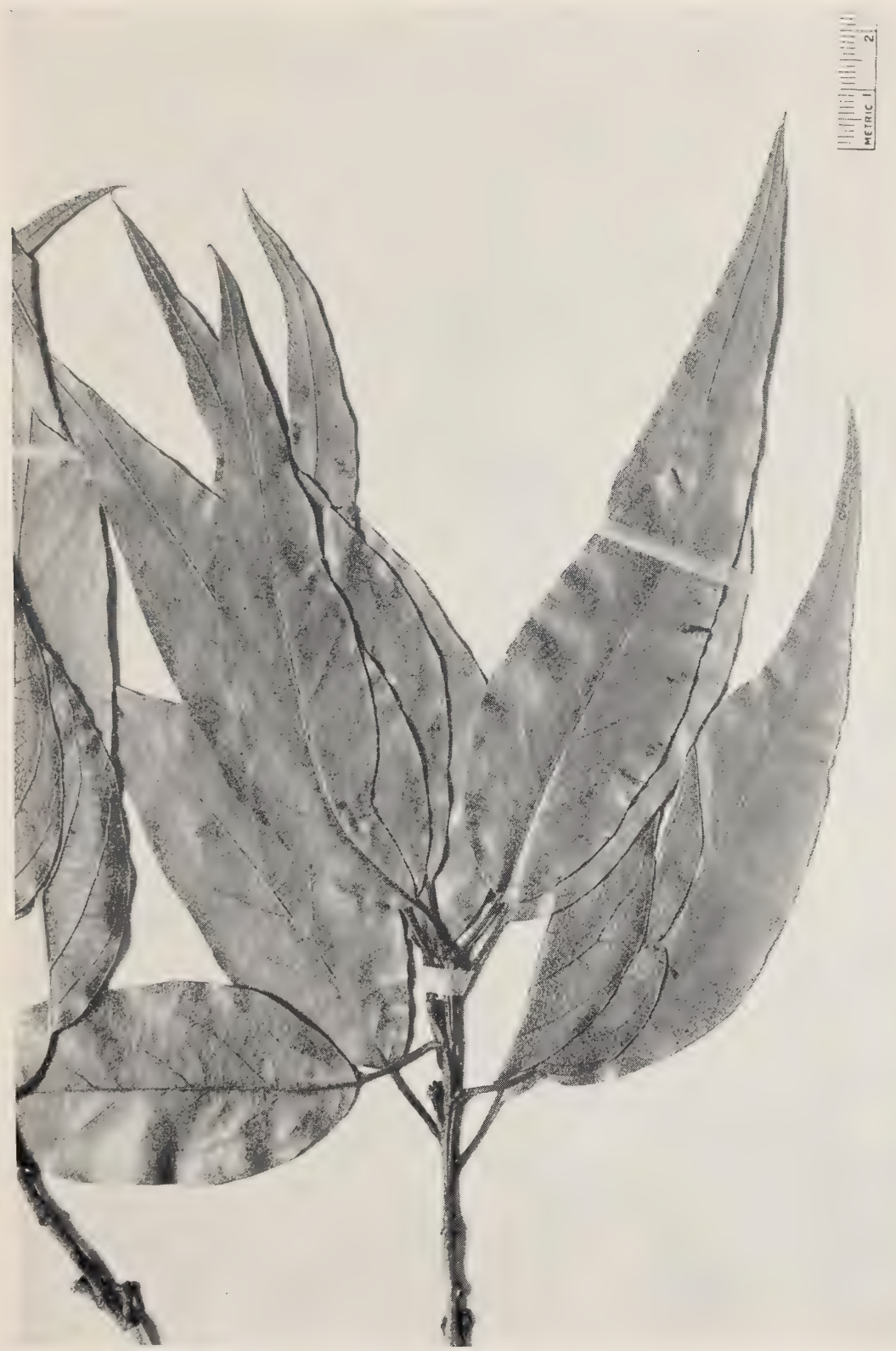

Quercus conspersa Benth. A common form from Guatemala, representative of what has been called $Q$. correpta Trel. (Cook 288-US). 
200 MisC. PUBLICATION 477 , U. S. DEPT. OF AGRICULTURE

Miscellaneous Publication 477, U. S. Dept. of Agriculture

PLATE 108

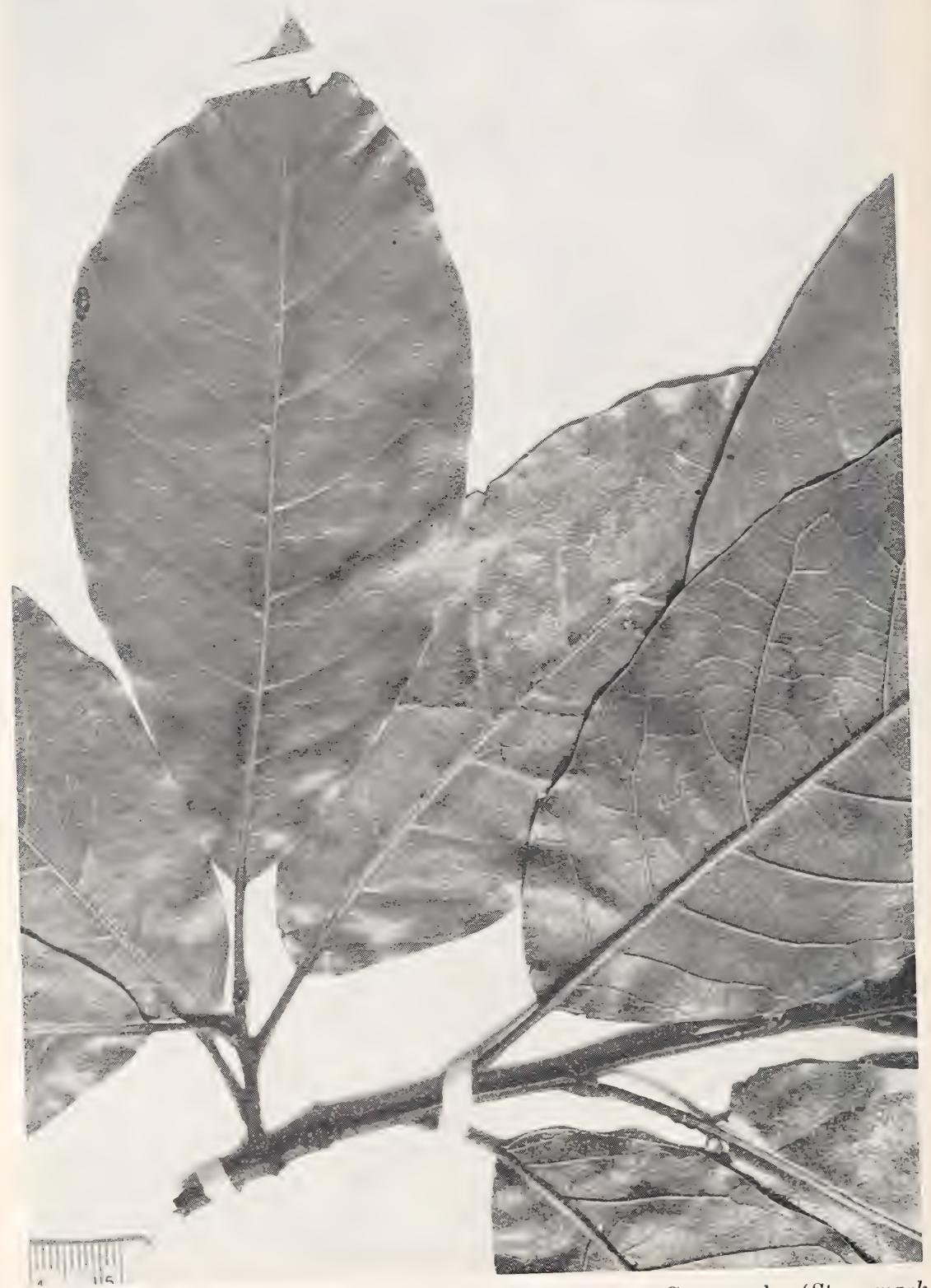

Quercus conspersa Benth. An extreme variant from Guatemala (Steyermark 32937- T). 


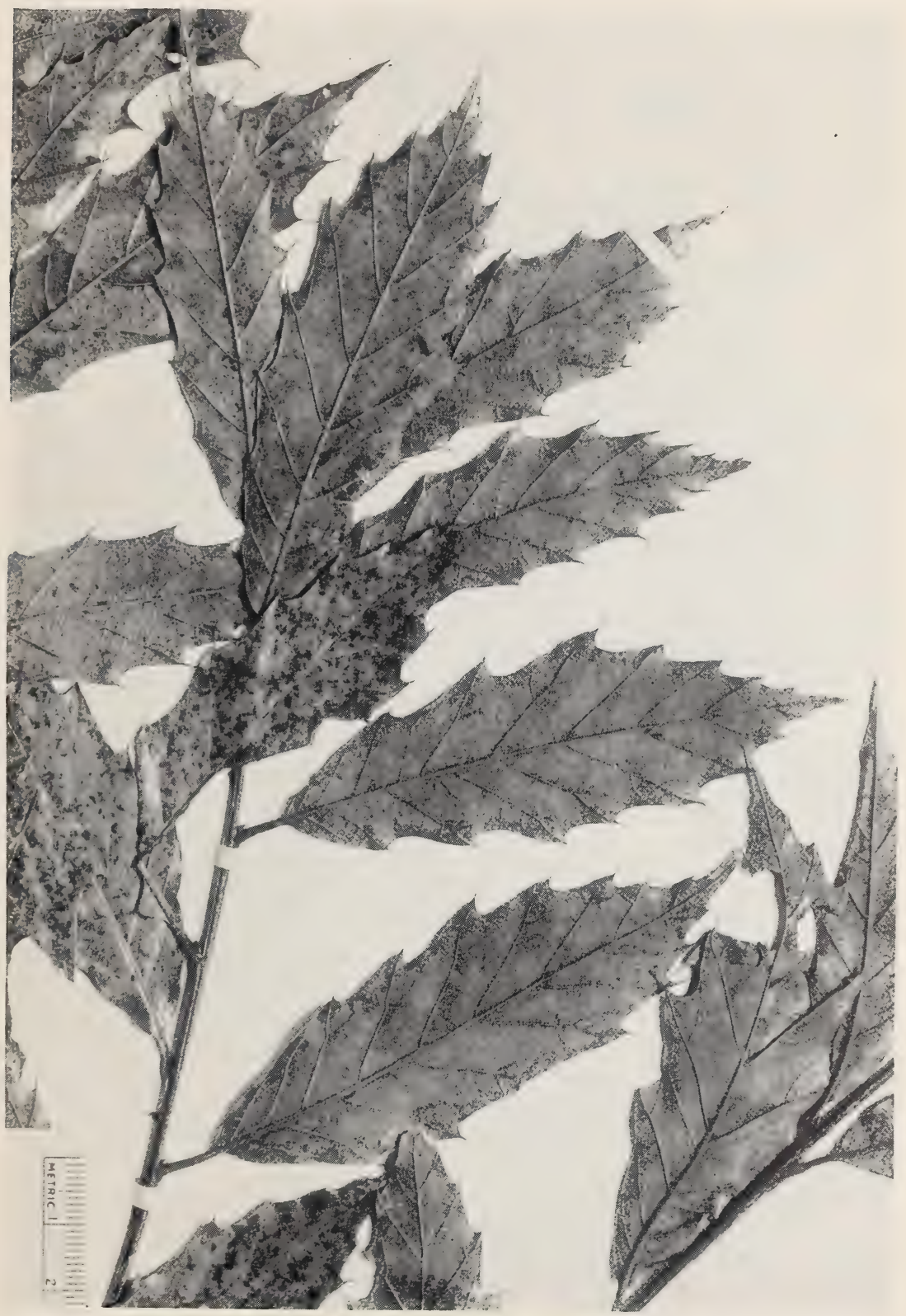

Quercus conspersa Benth. An extreme variant from Guatemala (Standley 59741-F). 
202 IIISC. PUBLICATION $4 \pi ;$, U. $\mathrm{s}$. DEPT. OF AGRICULTURE

Miscellaneous Publication 477, U. S. Dept. of Agriculture

PLATE 110


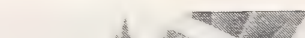

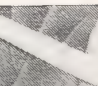

4
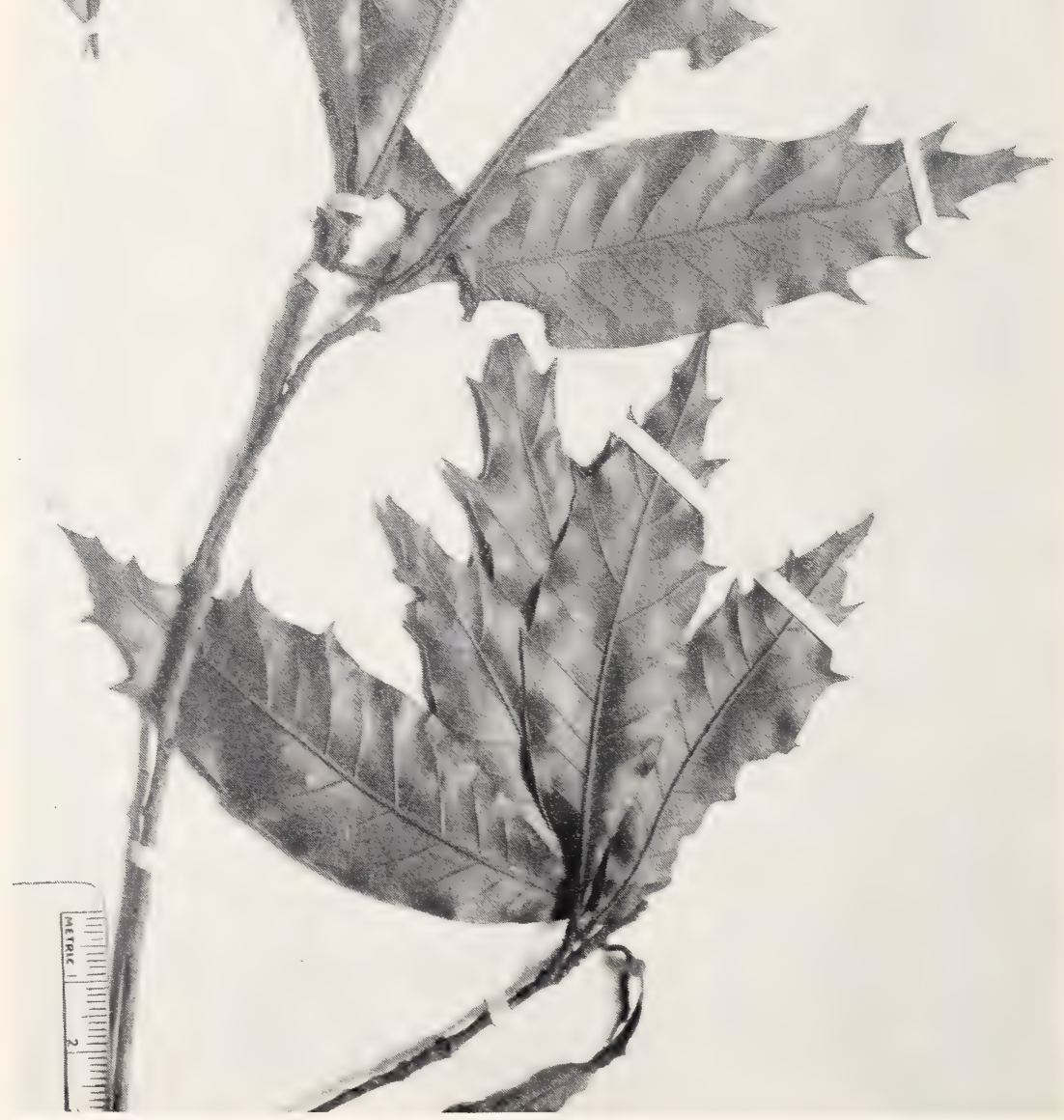

Quercus brenesii Trel. Isotype from Costa Rica (Brenes 14520-US). 


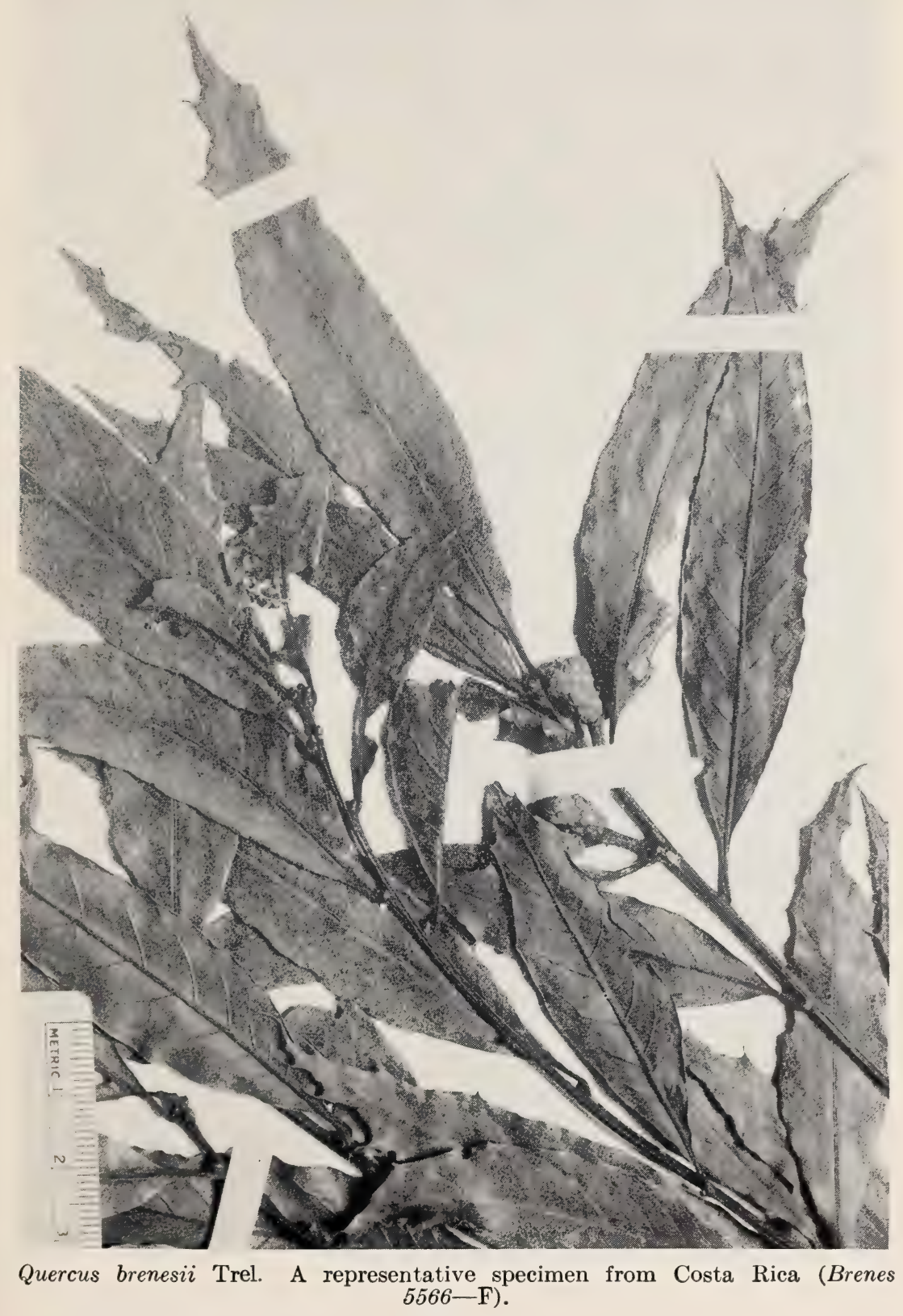


204 MISC. PLBLICATION 477, U. S. DEPT. OF AGRICULTURE



Quercus tenuiaristata Trel. Isotype from Honduras (Yuncker, Dawson, and Youse 6204-DeP). 


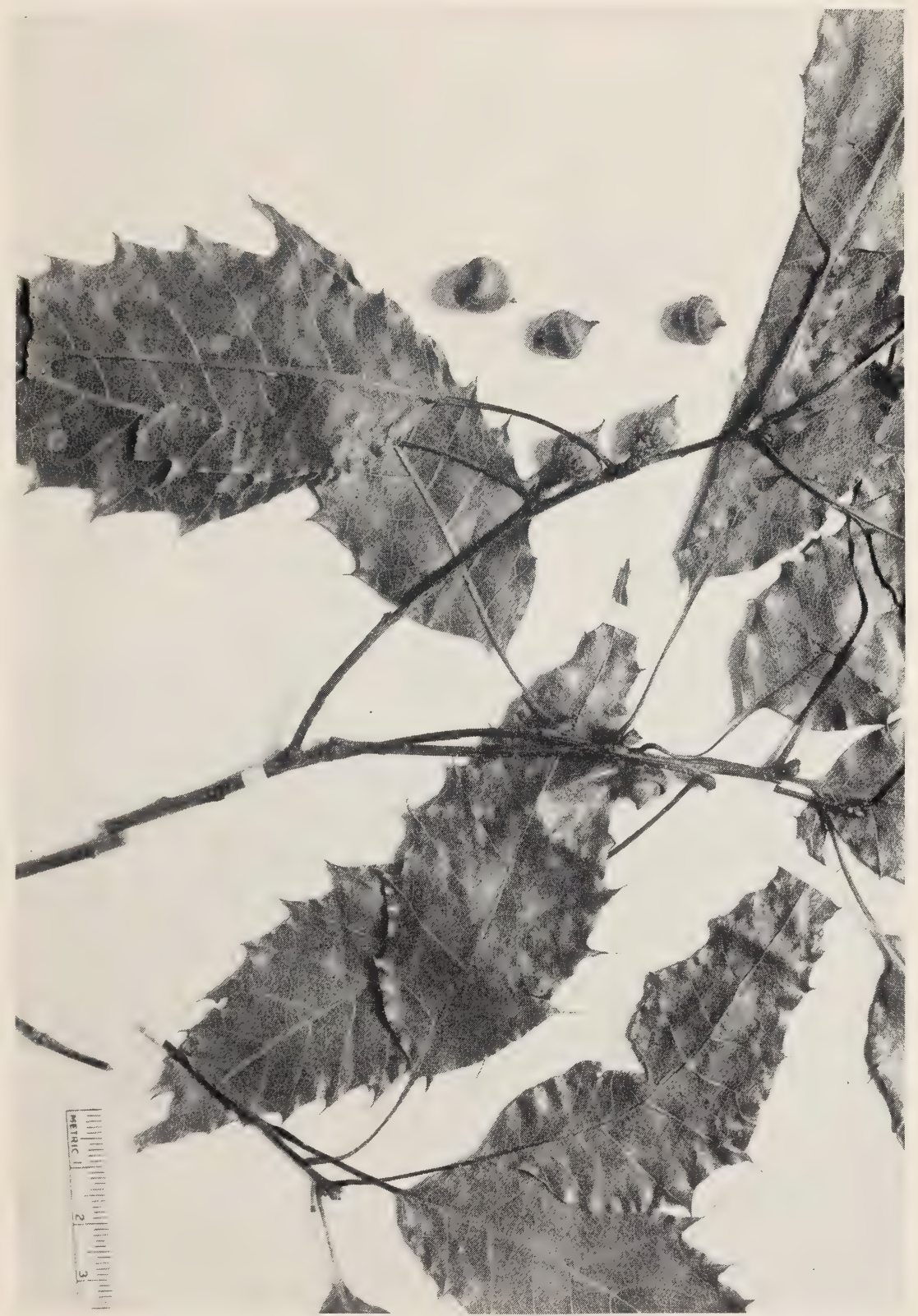

Quercus paxtalensis sp. nov. Isotype from Chiapas, Mexico (Matuda 1724-AA). 


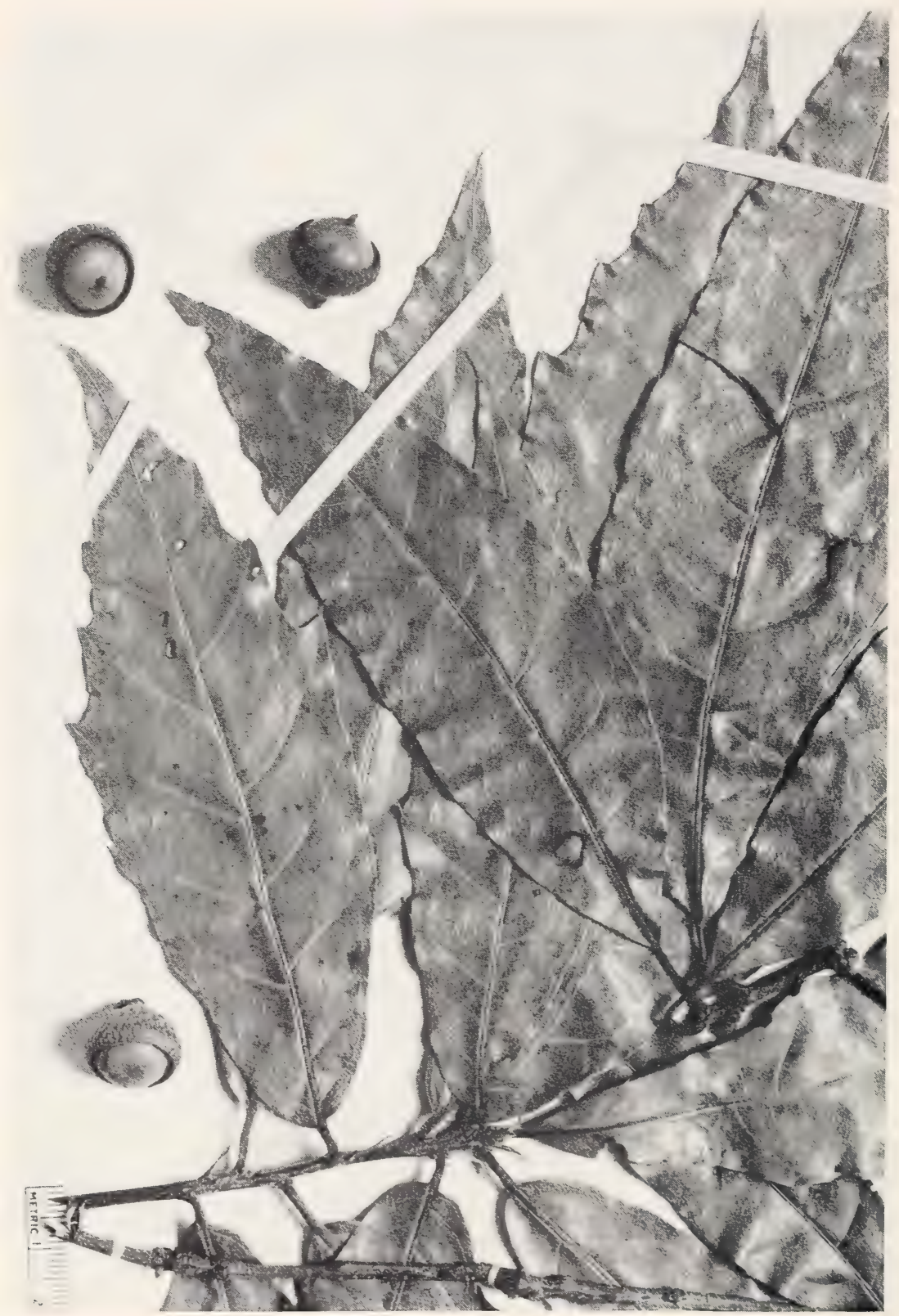

Quercus anglohondurensis sp. nov. Type from British Honduras (Lundell 6615-Mi). 


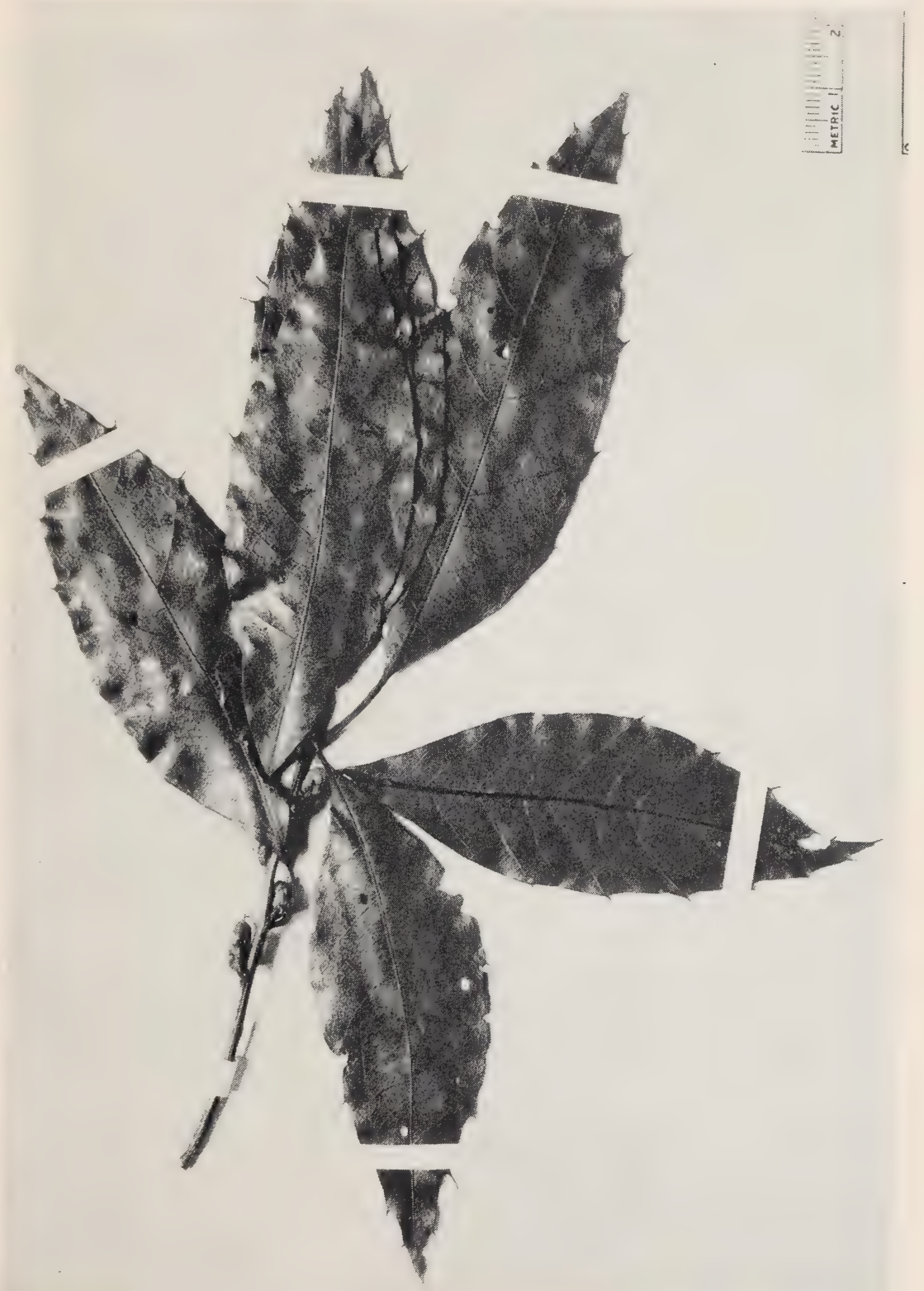

Quercus anglohondurensis sp. nov. Representative immature specimen from British Honduras (Schipp 1249-AA). 


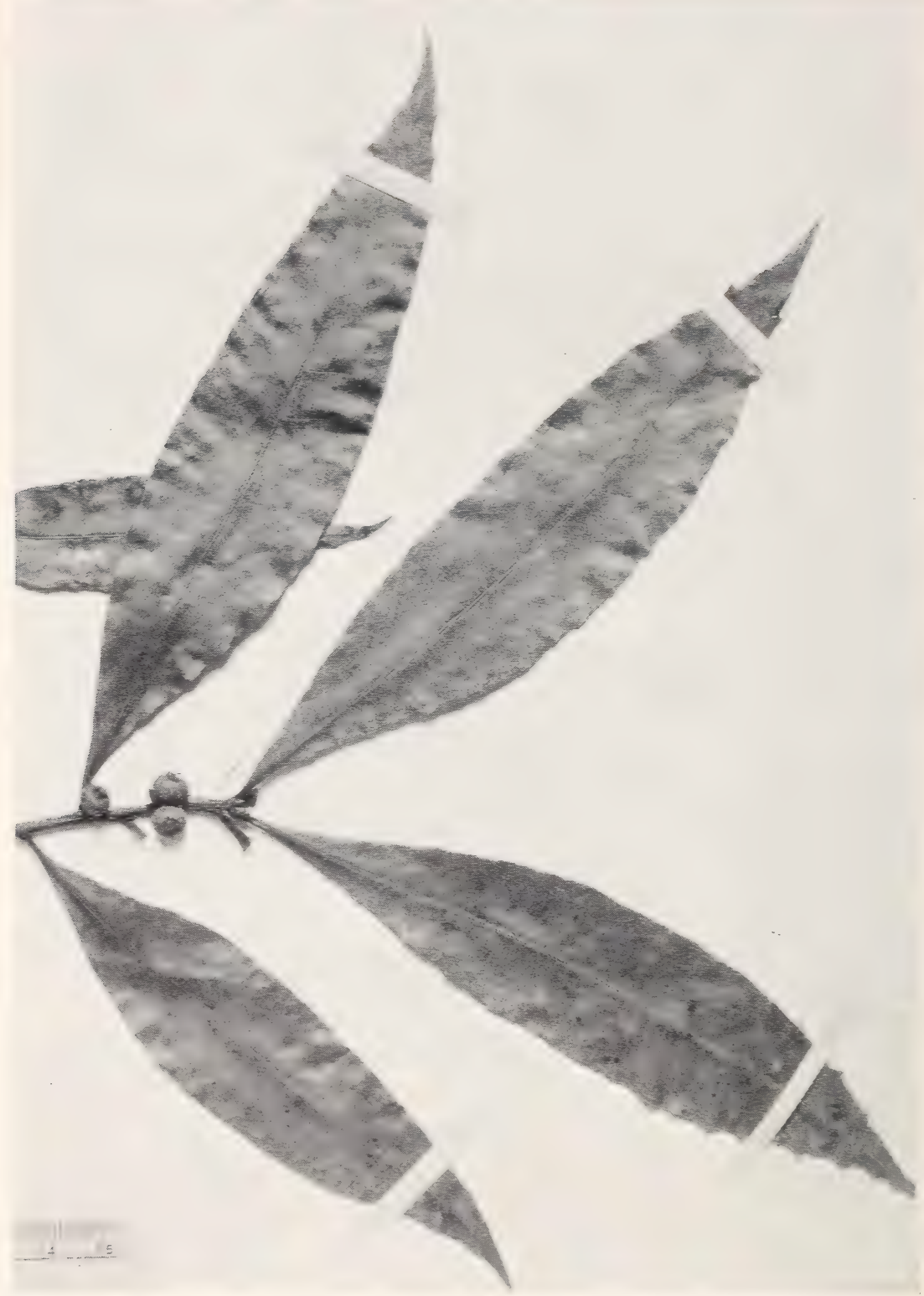

Quercus gracilior sp. nov. Trpe from Honduras (Edwards 285-AA). 


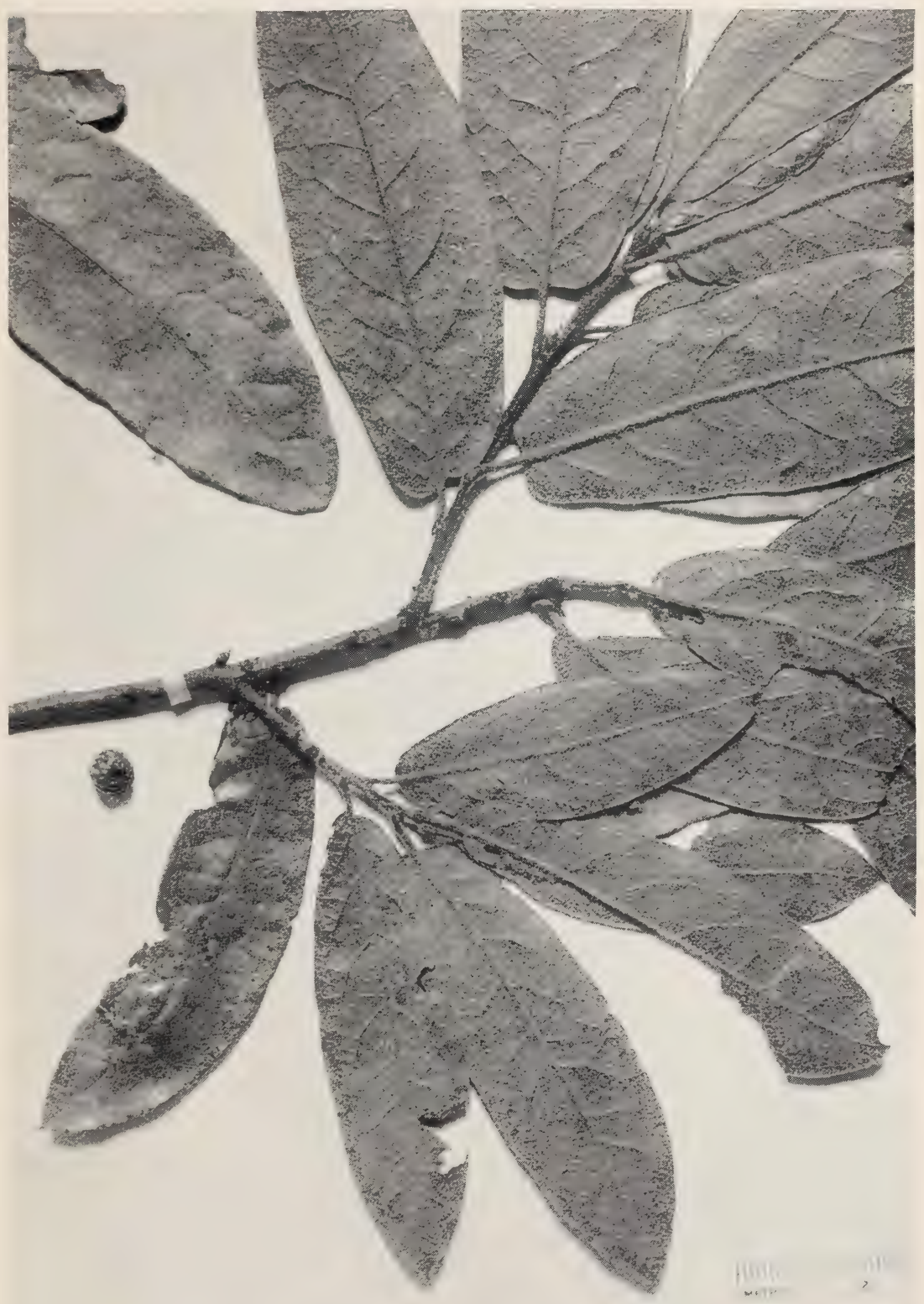

Quercus crispipilis Trel. Isotype from Guatemala (Seler 2667-G). 


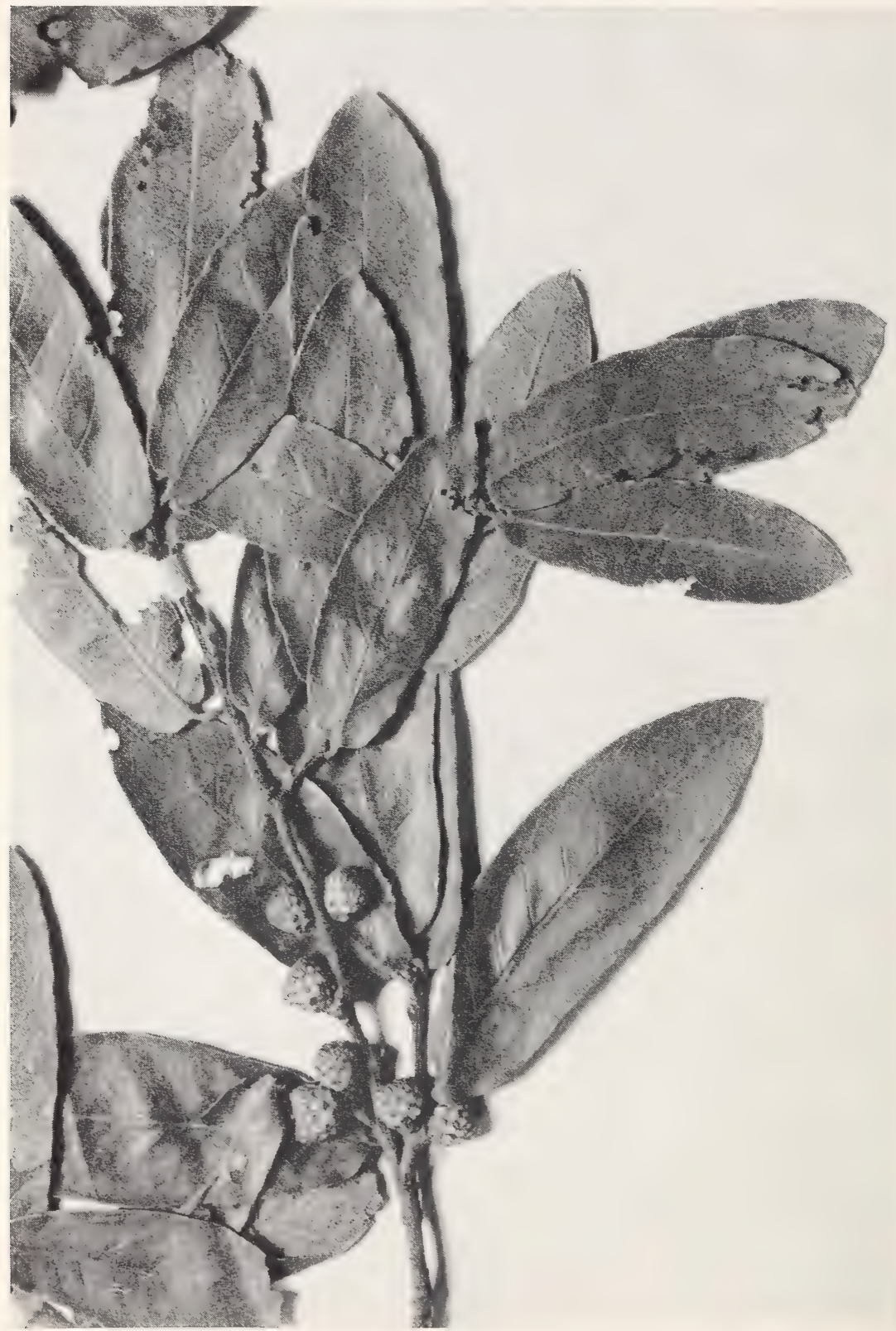

Quercus crispipitis Trel. A characteristic specimen from Chiapas, Mexico (Cook 99-US). 


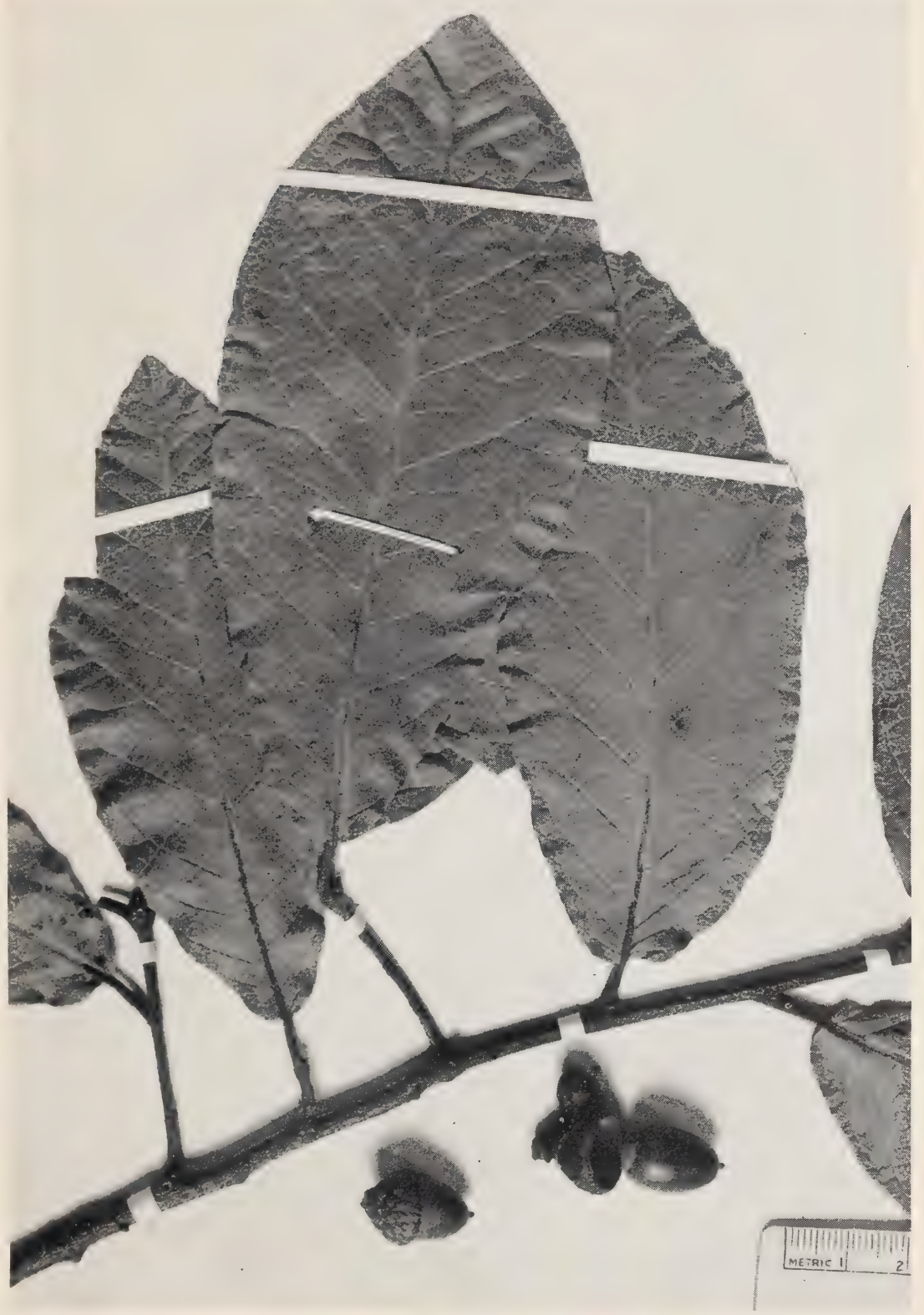

Quercus crispipilis var. pannosifolia (C. H. Mull.) comb. nov. Isotype of $Q$. pannosifolia C. H. Mull. from Guatemala (Skutch 698-US). 

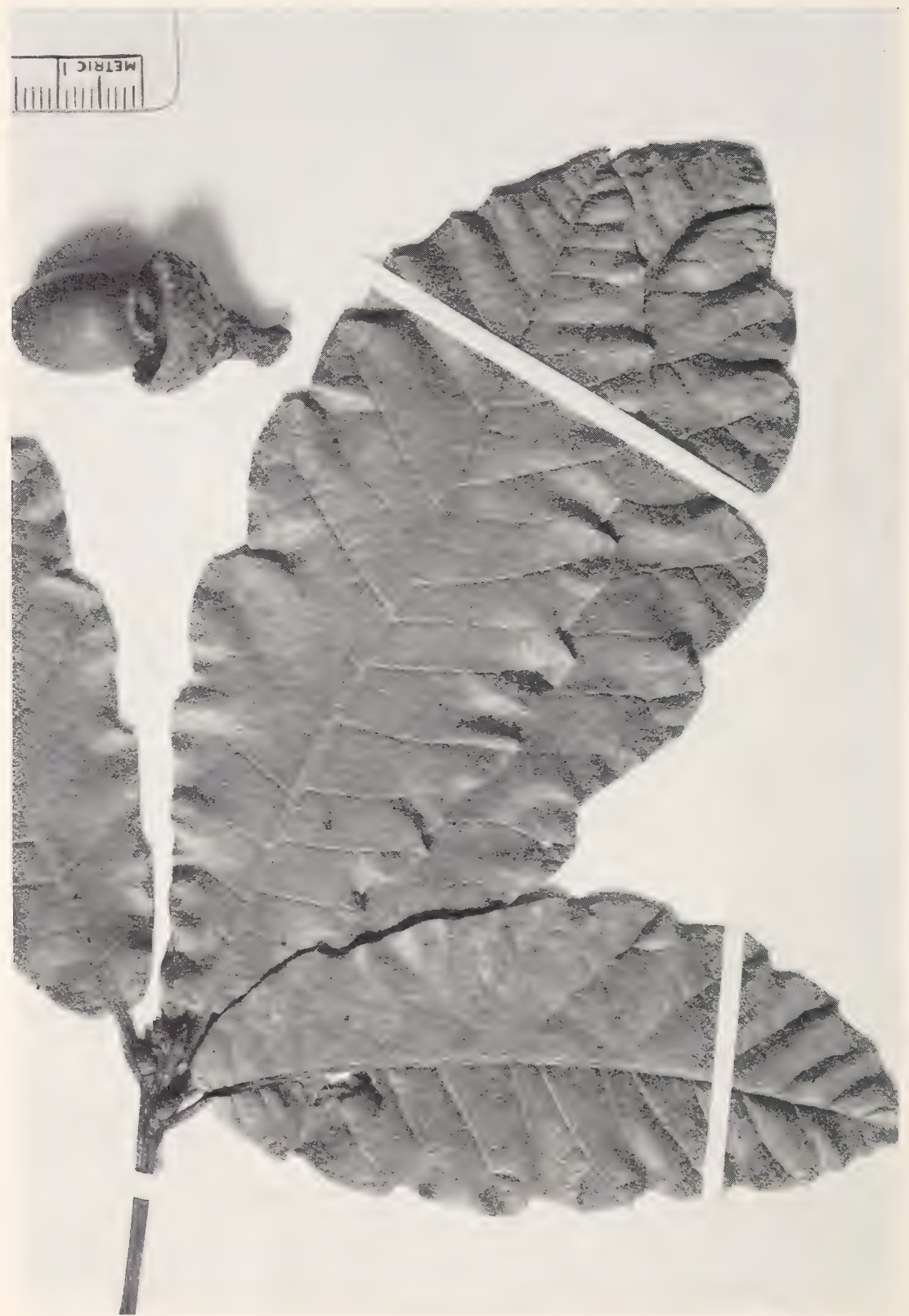

Quercus crispipilis var. pannosifolia (C. H. Mull.) comb. nov. Isotype of $Q$. chichavacana f. sublobata C. H. Mull. from Guatemala (Skutch 712-US). 


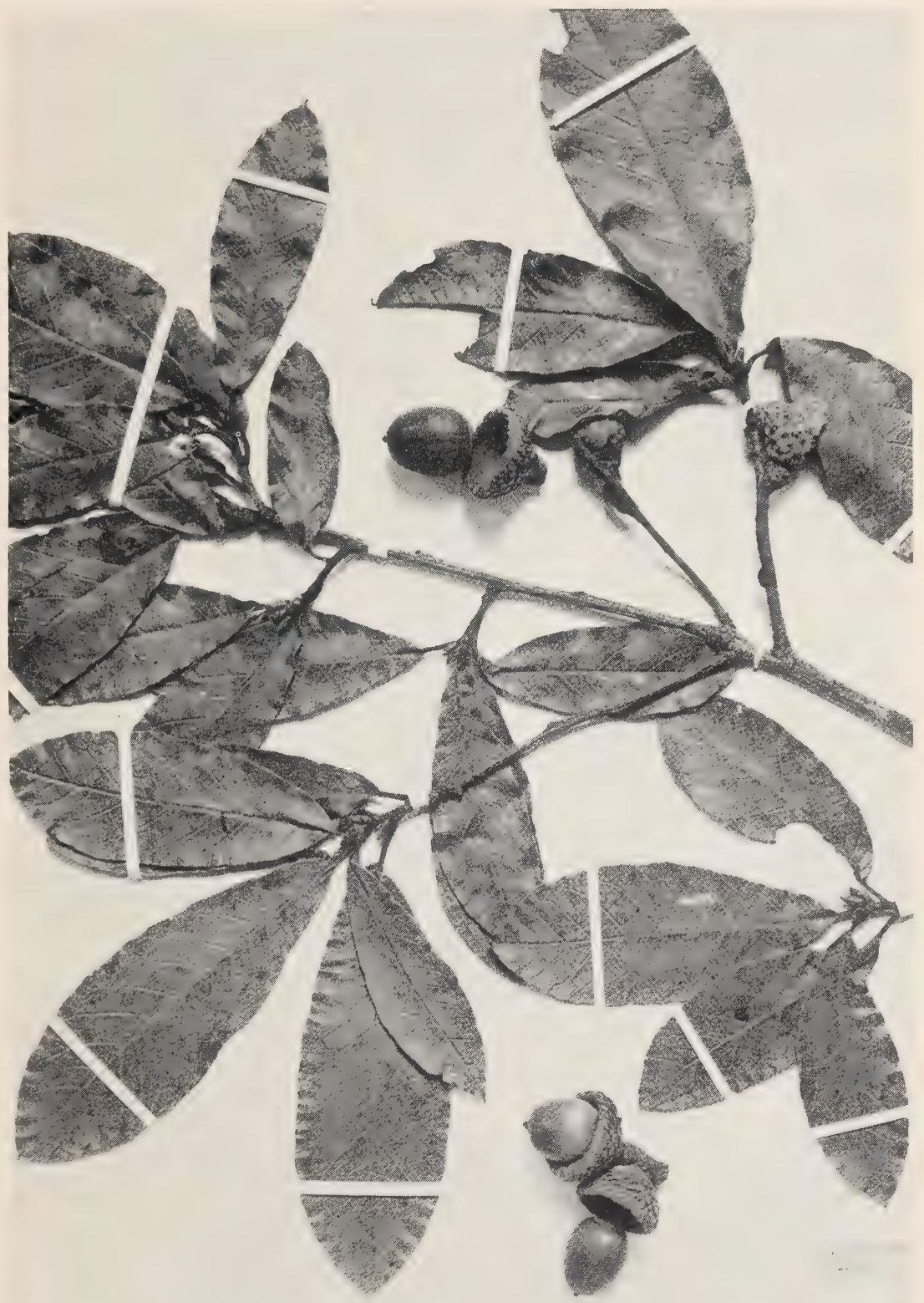

Quercus crispipilis var. pannosifolia (C. H. Mull.) comb. nov. An intermediate form, type of Q. skutchii Trel. from Guatemala (Skutch $44-\mathrm{US})$. 
214 MISC. PUBLICATION 477 , U. S. DEPT. OF AGRICULTURE

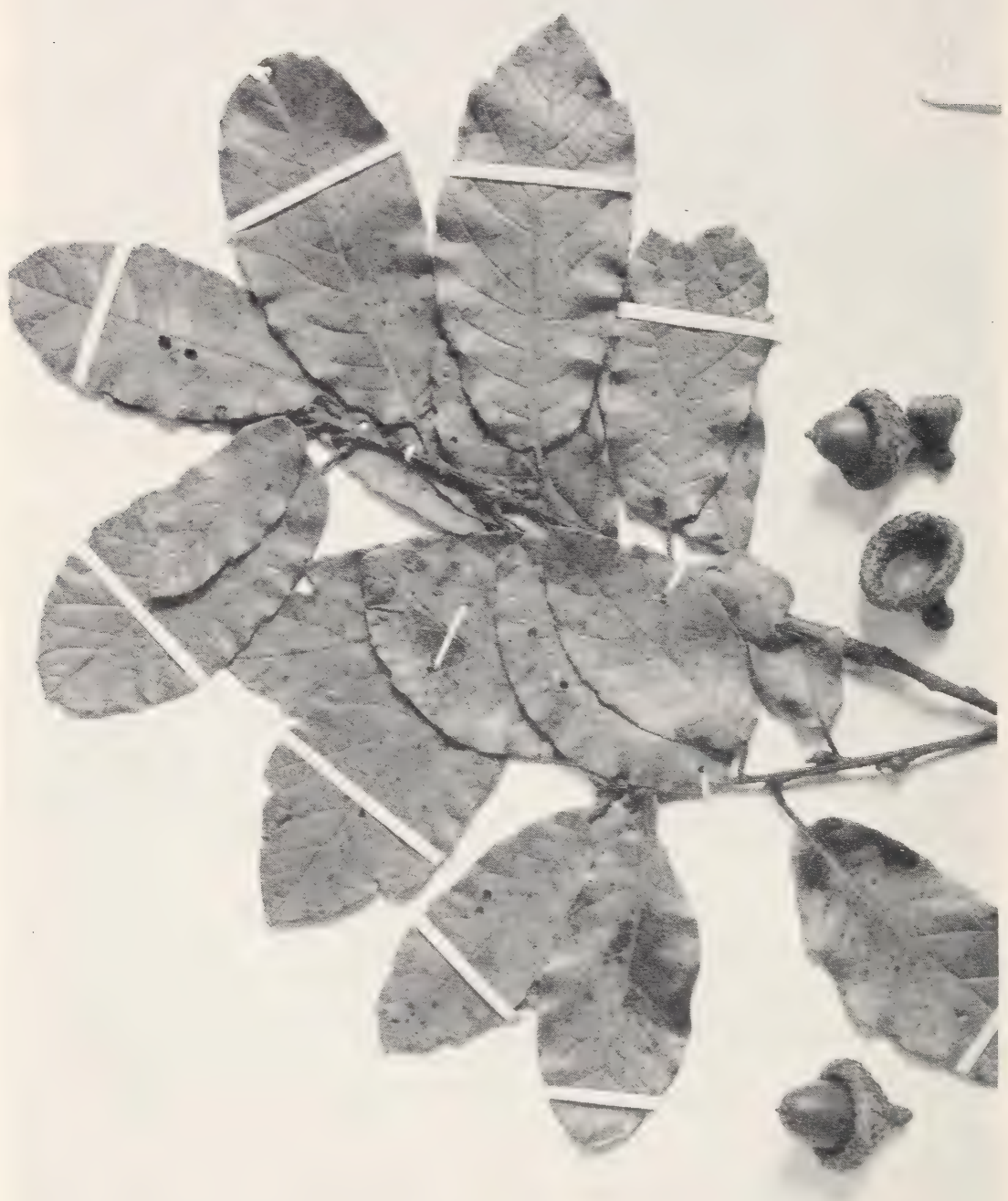

Quercus crispipitis var. pannosifolia (C. H. Mull.) comb. nov. Type of Q. chichavacana Trel. from Guatemala (Skutch 5\%-US). 


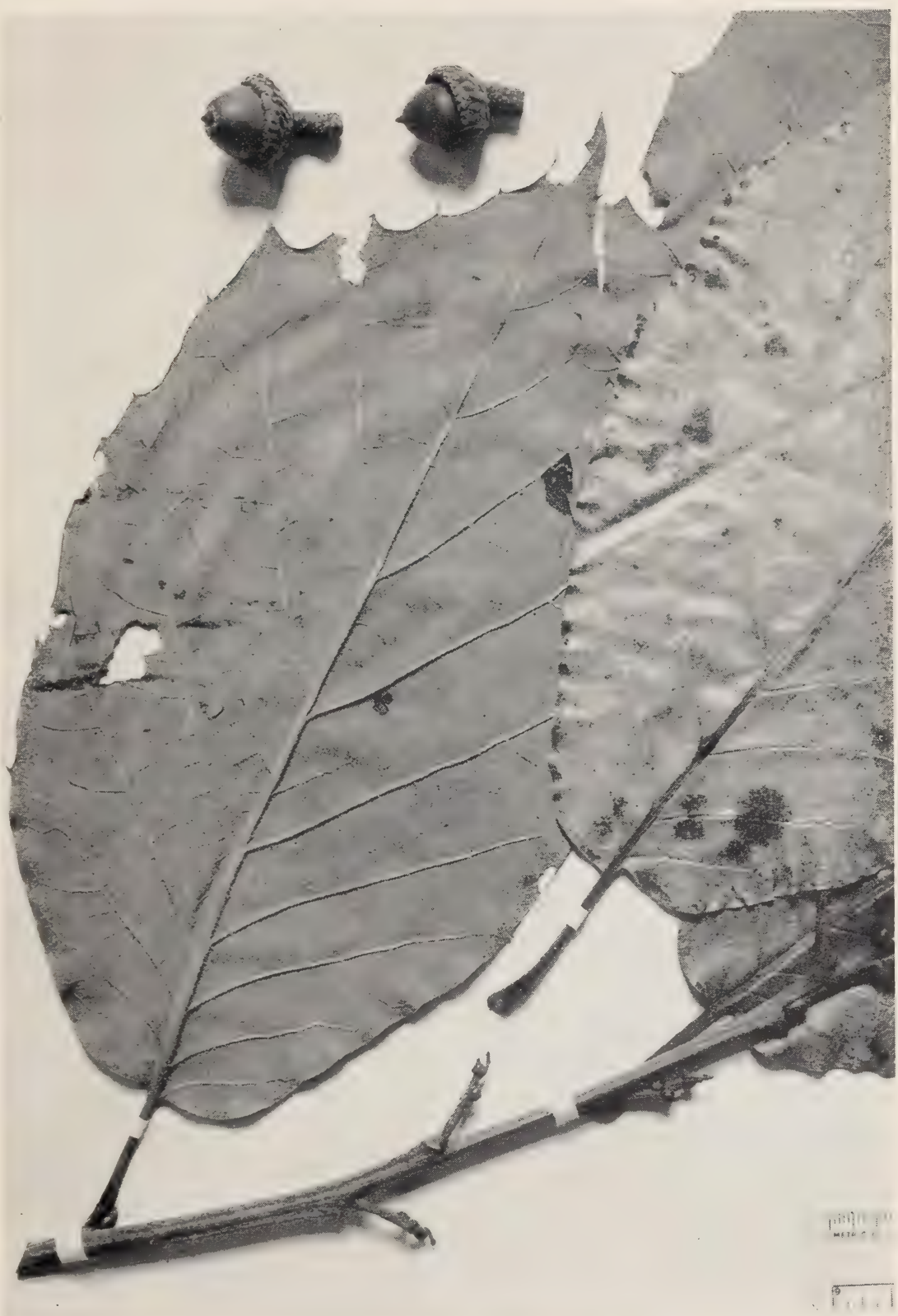

Quercus candicans Nee. A characteristic specimen from Guatemala (Skutch 1655AA). 


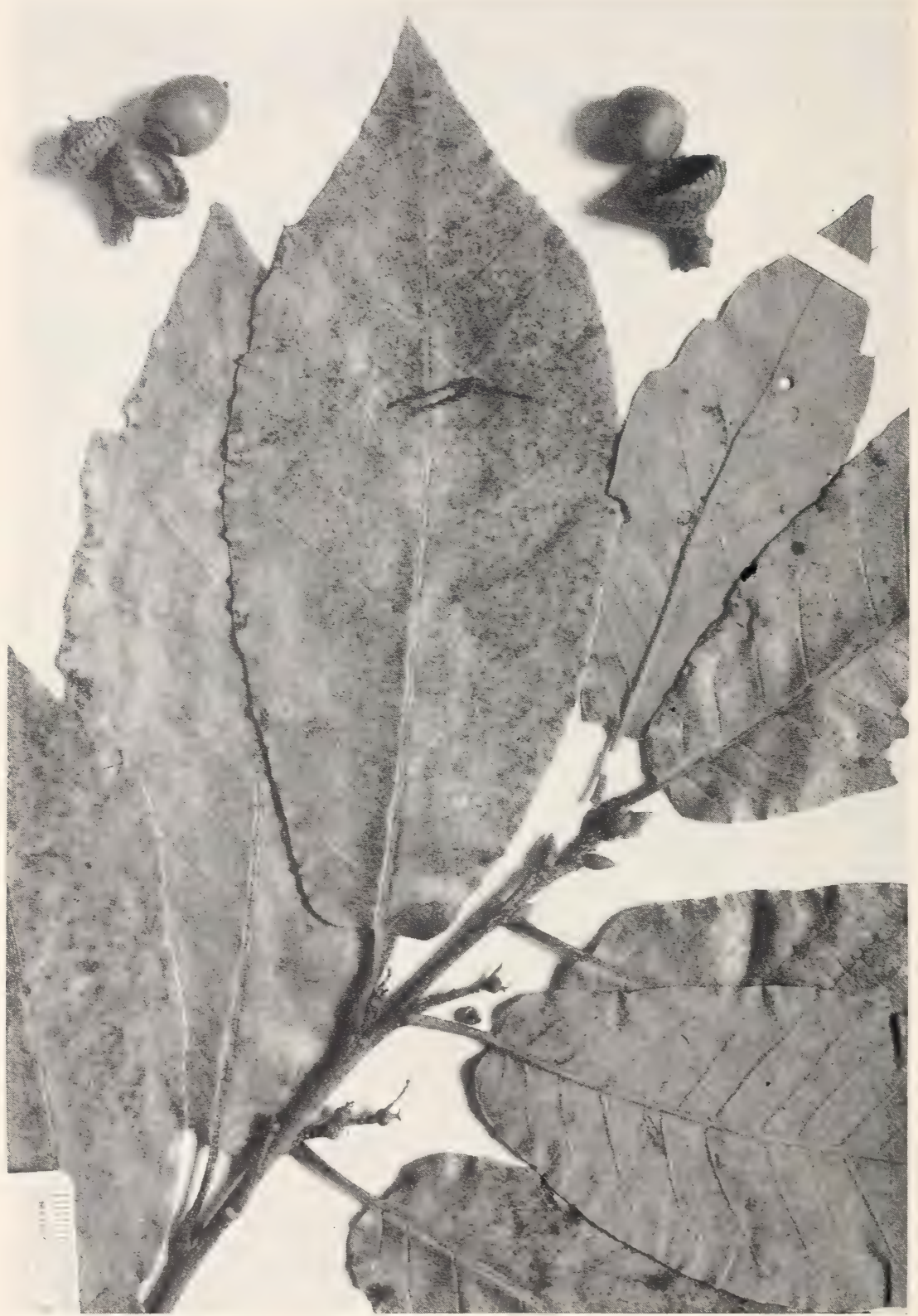

Quercus candicans Nee. A variant from Guatemala, type of $Q$. chimaltenangensis $\mathrm{f}$. gemmata C. H. Mull. (Skutch 1654-IIl). 




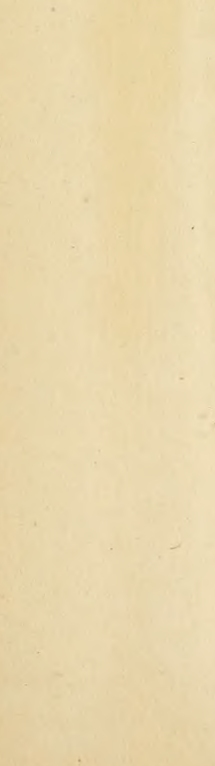


